ILANA MÜLLER

COOPERAÇÃO JURÍDICA INTERNACIONAL EM MATÉRIA PENAL E SEUS REFLEXOS NO DIREITO À PROVA NO PROCESSO PENAL BRASILEIRO

Orientador: Prof. Dr. Antonio Magalhães Gomes Filho

UNIVERSIDADE DE SÃo PAULO

FACULDADE DE DIREITO

SÃo PAUlO

2013 


\section{COOPERAÇÃO JURÍDICA INTERNACIONAL EM MATÉRIA PENAL E SEUS REFLEXOS NO DIREITO À PROVA} NO PROCESSO PENAL BRASILEIRO

Tese apresentada ao Programa de Pós-Graduação em Direito da Faculdade de Direito da Universidade de São Paulo como requisito parcial para obtenção do título de Doutor em Direito.

Área de concentração: Direito Processual.

Orientador: Prof. Dr. Antonio Magalhães Gomes Filho

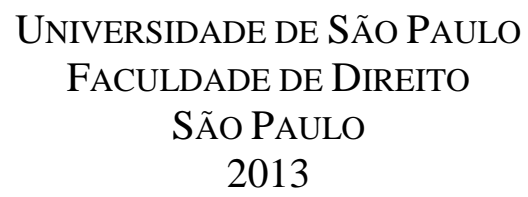


Nome: MÜLLER, ILANA.

Título: Cooperação jurídica internacional em matéria penal e seus reflexos no direito à prova no processo penal brasileiro.

Tese apresentada ao Programa de Pós-Graduação em Direito da Faculdade de Direito da Universidade de São Paulo como requisito parcial para obtenção do título de Doutor em Direito.

Área de concentração: Direito Processual.

Aprovado em:

Banca Examinadora

Instituição:

Julgamento: Assinatura:

Prof. Dr. Instituição:

Julgamento: Assinatura:

Prof. Dr. Instituição:

Julgamento: Assinatura:

Prof. Dr. Instituição:

Julgamento: Assinatura:

Prof. Dr. Instituição:

Julgamento: Assinatura: 
Aos meus, mais que pais, amigos, Roberto e Tânia, exemplos de vida e de dedicação, que sempre estimularam o gosto pelo estudo.

Ao meи irmão, colega de profissão e companheiro de todas as horas. À minha irmã e sobrinho, pelo amor e carinho. 


\section{AGRADECIMENTOS}

Agradeço ao meu orientador Prof. Dr. Antonio Magalhães Gomes Filho, mestre a ser seguido, pelo que me fez compreender o processo penal e, sobretudo, pelo cultivo de uma visão crítica do direito.

Aos professores André de Carvalho Ramos e Gustavo Henrique Righi Ivahy Badaró, examinadores da comissão julgadora de qualificação, pelas sugestões e críticas à estrutura deste trabalho, que instigaram o aperfeiçoamento do presente estudo.

Aos demais professores das disciplinas cursadas no programa de pós-graduação: Antonio Scarance Fernandes, Maria Thereza Rocha de Assis Moura, José Raul Gavião, Maurício Zanoide de Morais Almeida, Marcos Alexandre Coelho Zilli, Celso Laffer e Wagner Menezes.

Ao meu irmão Carlo Frederico Müller, sócio e companheiro, pelo apoio, carinho e paciência durante o período em que me dediquei à elaboração desta tese.

Aos meus queridos amigos e colegas de profissão Valdir Abibe, Pedro Iokoi e Andrea Cristina D'Angelo, pela dedicação, contribuições e críticas ao presente trabalho, sempre pertinentes.

À Charlotte Assuf e Guilherme Madeira pela amizade e ajuda.

À minha tia, Profa. Dra. Kátia Bueno Romanelli, pelo auxílio.

A todos aqueles que, de alguma forma, me ajudaram a concluir esta tese. 


\section{RESUMO}

O presente trabalho trata da questão da Cooperação Jurídica Internacional em matéria penal e seus reflexos no direito à prova no processo penal brasileiro, nos diferentes pontos de intersecção de diversos temas contemporâneos, decorrentes da globalização da economia e da crescente demanda de segurança pública internacional. Em razão dessa tendência, vimos cada vez mais o risco de violação das garantias inerentes ao justo processo, asseguradas aos acusados em geral, no que concerne ao direito à prova. Neste sentido, o estudo que ora realizamos aborda as questões dos mecanismos de cooperação jurídica internacional, em um mundo de diversidade cultural, em matéria de prova penal, quando o Brasil é o país requerente; das garantias processuais inerentes ao justo processo, asseguradas pelos direitos humanos, que constitui o padrão normativo da cooperação; dos limites impostos pela soberania e ordem pública na cooperação jurídica; da admissibilidade da prova produzida no exterior e o respeito ao núcleo central dos direitos fundamentais (vida privada, intimidade etc.), sob a ótica do ordenamento jurídico brasileiro, de modo a evitar, insegurança jurídica e a inadmissibilidade da prova. Procurou-se demonstrar a importância do direito à prova no processo penal e a necessidade de se garantir paridade de armas na cooperação, com eficácia, propugnando-se pela normatização e harmonização das legislações, de modo a permitir a admissibilidade das provas obtidas pela via cooperacional. A pesquisa e o exame das fontes bibliográficas utilizadas foram fundamentais para a realização desta tese. 


\begin{abstract}
The present work is about the International Legal Cooperation regarding penal matters and the repercussions in the right to proof in the Brazilian Prosecution, upon the different intersection points of several contemporary themes from the globalization of the economy and the rising demand on international public security. As for this tendency, the risk of breach of warranties inherent in the due process is currently perceived, insured to the accused ones in general, on the issue of right to proof. In this sense, the study here presented approaches the issues of the mechanisms on the international legal cooperation, in a world of cultural diversity, concerning the evidence in criminal proceedings, when Brazil is the claimant country; of the warranties inherent in the due process, insured by the human rights, constituting the normative standards of the cooperation; the limits imposed by the sovereignty and the public order in the legal cooperation; the admissibility of the presented evidence abroad and concerning the core of the fundamental rights (private life, intimacy etc.), from the perspective of the Brazilian legal system, as to prevent legal uncertainty and the inadmissibility of evidence. In order to demonstrate the importance of the right to proof in criminal proceedings and the need to insure even parity in the cooperation, efficacy, advocating the standardization and harmony of the legislation, so as to enable the admissibility of the presented evidence via cooperation. The research and examination of the bibliographic sources were fundamental to this thesis accomplishment.
\end{abstract}




\begin{abstract}
ABRÉGÉ
Dans ce texte nous discutons la question de la Coopération juridique internationale en matière pénale et ses effets sur le droit à la preuve en procédure pénale brésilienne, à différents points d'intersection de plusieurs thèmes contemporains liés à la mondialisation de l'économie et à la demande croissante de sécurité publique internationale. Comme résultat de cette tendance nous assistons à l'accroissement du risque de violation des garanties inhérentes à la bonne procédure assurées aux accusés en général, en ce qui concerne le droit à la preuve. En ce sens, notre étude aborde les questions des mécanismes de coopération juridique internationale dans un monde de diversité culturelle, dans le domaine de preuve pénale, quand le pays requérant est le Brésil, tout comme les questions des garanties de procédures inhérentes à la bonne procédure assurées par les Droits de l'homme, ce qui constitue le modèle normatif de coopération; elle aborde encore les questions des limites imposées par la souveraineté et l'ordre public, en matière de coopération juridique, tout comme les questions de la recevabilité de la preuve produite à l'étranger et le respect du noyau dur des droits fondamentaux (vie privée, intimité, etc.), dans la perspective de l'ensemble des lois et organisations judiciaires brésilien - le système juridique - afin d'éviter et le doute juridique et l'irrecevabilité de la preuve. Nous avons cherché à démontrer l'importance du droit à la preuve en procédure pénale et la nécessité d'assurer la parité de moyens en coopération, de façon efficace, tout en préconisant la normalisation et l'harmonisation des législations, de façon à permettre la recevabilité des preuves obtenues au travers la bonne coopération. La recherche et l'examen des sources bibliographiques utilisées se sont révélés indispensables à la réalisation de cette thèse.
\end{abstract}




\section{SUMÁRIO}

INTRODUÇÃO

1. ASPECTOS GERAIS RELATIVOS À GLOBALIZAÇÃO E À 15 CONSAGRAÇÃO DOS DIREITOS HUMANOS UNIVERSAIS.

1.1 Política externa brasileira no mundo globalizado e cooperação jurídica internacional em matéria penal.

1.2 Relação de direitos humanos e direito interno brasileiro: padrão normativo para a cooperação jurídica internacional.

1.3 Criminalidade organizada e cooperação jurídica internacional em matéria penal.

2.1 Noções: terminologia adotada, conceito e normatização.

2.2 Vetores da cooperação jurídica internacional: soberania, cooperação interessada, reconhecimento mútuo e princípio da confiança.

2.3 Considerações gerais acerca da classificação da cooperação jurídica internacional.

2.4 Apontamentos sobre os instrumentos utilizados pela cooperação jurídica internacional em matéria de prova.

3.1. Considerações gerais sobre prova e indícios.

3.2. Correlação entre a prova e a busca da verdade atingível. 
4. GRANDES QUESTÕES DO DIREITO À PROVA NA COOPERAÇÃO 107 JURÍDICA INTERNACIONAL DA ATUALIDADE

4.1. Considerações sobre a cooperação jurídica em matéria penal na Europa e na 116 América Latina

4.2. Considerações sobre os tratados Bilaterais firmados pelo Brasil e outros Estados- 136 Nações relativos à cooperação jurídica com matéria penal.

4.3. Reflexos da prova produzida por meio da cooperação jurídica internacional 145 (ordem pública, violação de direitos e garantias individuais, sigilo bancário e fiscal, DNA e sangue).

4.4. Proposição: da quebra da linearidade rígida pró-defesa para a produção de provas 164 no processo penal 


\section{INTRODUÇÃO}

Este trabalho intitula-se "Cooperação Jurídica Internacional em matéria penal e seus reflexos no direito à prova no processo penal brasileiro".

Diante da globalização, o mundo atual enfrenta constantes crises financeiras, sob o impacto da revolução das informações e da necessidade econômica de maior interdependência entre os Estados.

A expansão dos canais e contatos transnacionais em distâncias multicontinentais embasam a ideia de que mais políticas deverão ser implementadas internacionalmente, incluindo regulamentações e práticas antes consideradas prerrogativas de governos nacionais.

Tal revolução das informações acrescentou à globalização contemporânea rapidez e intensidade na rede de interligações que a tornam mais complexa, mas de maneira desigual, variando de acordo com a região e a localidade e de acordo com o problema.

Não se há de negar que, frente à globalização da economia e à crescente demanda de segurança pública, exigida cada vez mais e com maior rigor, em especial, após os atentados de 11 de setembro nos Estados Unidos da América e das questões geopolíticas em voga no mundo, a sociedade modificou-se nos últimos tempos.

Depara-se cada vez mais com o fenômeno de enrijecimento de políticas criminais e legislações penais, visando reprimir a criminalidade que transcende às barreiras nacionais, existindo uma intensificação da cooperação jurídica internacional entre os Estados no combate ao crime organizado, terrorismo, tráfico de drogas, lavagem de dinheiro, dentre outros.

Como é cediço, os mecanismos de cooperação jurídica internacional desenvolvem-se em uma sociedade caracterizada pelo pluralismo cultural e encontram entraves na grande diversidade de sistemas jurídicos existentes, cuja harmonização se torna necessária como forma de propiciar a eficiência da cooperação jurídica internacional e a eficácia da prova produzida no exterior.

É preciso compreender que as garantias processuais, previstas na Constituição Federal/ 88 e em tratados internacionais dos quais o Brasil é signatário, constituem balizas de validade da cooperação, não sendo lícito buscar a verdade real ou atingível a qualquer custo. 
Nesse sentido, as garantias judiciais, inerentes a um processo penal justo (princípio da legalidade, da não retroatividade das leis penais, de non bis in idem, da presunção de inocência, das garantias de defesa do acusado, do contraditório, da reserva do juiz, do direito de ser julgado em prazo razoável, entre outros) não podem ser tidas como empecilho à cooperação jurídica internacional.

Embora existam diversos mecanismos de cooperação jurídica horizontal em matéria penal, adotados no Brasil, optou-se pela análise daqueles relacionados ao direito à prova no processo penal, que integra o quadro de mínimas garantias ínsitas ao processo penal justo, assegurado, inclusive, pela Convenção Americana de Direitos do Homem, pelo Pacto Internacional sobre Direitos Civis e Políticos, dentre outros tratados internacionais, de significativa relevância.

Como é cediço, existe - não apenas no Brasil - no campo do direito constitucional e dos direitos fundamentais, um déficit quanto ao direito à prova, encontrando-se, esse direito, na maioria das vezes, ou dissolvido nos princípios de direito e de processo penal consagrados constitucionalmente (direito à ampla defesa, ao contraditório, de intervenção no processo, de proibição de provas ilícitas) ou associado ao direito e à tutela jurisdicional.

Nesse contexto, a incorporação das garantias contidas na Convenção Americana sobre Direitos do Homem e no Pacto Internacional sobre os Direitos Civis e Políticos foi de extrema importância para a consagração definitiva e expressa do direito à prova no ordenamento jurídico brasileiro, não obstante esse direito (ínsito ao contraditório) já estivesse implícito nas garantias fundamentais asseguradas pela Constituição.

Por tais razões, escolheu-se como título Cooperação Jurídica Internacional em Matéria Penal e seus reflexos no direito à prova no processo penal brasileiro, visto que o objeto de estudo aborda, necessariamente, as principais questões relativas às dificuldades enfrentadas no processamento da cooperação jurídica internacional ativa em matéria penal, no que se refere à produção - quer pela acusação, quer pela defesa - e à admissibilidade das provas, de modo a se garantir o justo processo, sob a ótica do binômio eficiência e garantismo.

Evidentemente que este tema passa pela análise da internacionalização dos direitos humanos - que servem de padrão normativo universal - e sua relação com o direito interno e com questões afetas à soberania nacional e à ordem pública. 
Almeja-se traçar linhas gerais que viabilizem e equilibrem a necessidade de uma cooperação internacional, rápida e eficaz, com as garantias fundamentais (asseguradas constitucionalmente e em tratados de direitos humanos), sem as quais não existirá justo processo. Evidentemente não se esgotará a análise de todas as questões relativas à prova na cooperação jurídica internacional e sua validade no direito interno.

O tema permite uma reflexão sobre pontos de intersecção de diversos temas contemporâneos do processo penal, visto constituir a globalização, atualmente, o novo paradigma da política criminal, no sentido de que, frente à internacionalização do crime, urge responder com a internacionalização da política do combate ao crime.

Nesse sentido, a cooperação jurídica em matéria penal desenvolveu-se e vem se intensificando sob a ótica da repressão aos delitos praticados ou que provocam consequências para além das barreiras nacionais.

Sem dúvida, na atualidade, é preciso criar, entre os operadores do direito, uma cultura de cooperação internacional, evidentemente com respeito às garantias fundamentais dos cidadãos, em especial, quando se trata de produção de provas e atos destinados ao processo de conhecimento na esfera criminal. Entretanto, deve-se atuar com proporcionalidade, de modo a impedir que ocorra a crescente e indesejável existência de estados policialescos, disfarçados de democráticos.

Dar-se-á enfoque ao estudo das modalidades de cooperação jurídica internacional ativa em matéria penal, no que se refere à produção de provas e sua admissibilidade no processo penal brasileiro sob a perspectiva universalista, levando-se em conta o binômio garantismo e efetividade. Abordar-se-á não somente provas requeridas pela acusação, mas também aquelas almejadas pela defesa, indispensáveis ao exercício efetivo do contraditório, como forma de se resguardar a garantia da paridade de armas.

É indispensável que se crie uma normatização básica quanto aos procedimentos de cooperação jurídica internacional, pelo processo de harmonização e respeito ao padrão normativo dos Direitos Humanos, não somente sob a ótica da acusação, mas principalmente sob a perspectiva do exercício da ampla defesa, que deve ser levado em consideração inclusive na elaboração e assinatura de tratados internacionais, bilaterais ou multilaterais e nos casos de auxílio judiciário entre Estados, que se dão mesmo diante de ausência normativa, baseados na confiança recíproca entre as nações. 
Nesse contexto, para alcançar o objetivo pleiteado, foi elaborada pesquisa de natureza qualitativa, por meio de amplo levantamento bibliográfico, cujo relatório final se estrutura em cinco partes, sendo a primeira delas esta Introdução.

No primeiro capítulo, apresentam-se aspectos gerais relativos à globalização e à consagração dos direitos humanos. No segundo, aborda-se a cooperação jurídica internacional em matéria penal, abrangendo seu conceito, instrumentos, dificuldades de implementação e reflexos no processo penal brasileiro. No terceiro capítulo, procura-se refletir acerca do conceito, da finalidade e da admissibilidade da prova a ser produzida por meio da cooperação jurídica internacional. Por fim, no quarto capítulo, discutem-se as grandes questões do direito à prova na cooperação jurídica internacional da atualidade. 


\section{Aspectos gerais relativos à globalização e à consagração dos direitos humanos.}

Inicia-se o estudo por uma breve abordagem referente aos aspectos gerais da globalização $^{1}$ e da sociedade internacional, bem como da internacionalização dos Direitos Humanos $^{2}$ que constituem, conforme se demonstrará no decorrer do trabalho, o padrão normativo universal a ser utilizado como forma de traçar as balizas da cooperação jurídica internacional, na medida em que se cria, para os Estados, a responsabilidade de proteção de valores consagrados como direitos do homem.

Não se há de olvidar que, embora a globalização - que não implica em universalidade - venha ocorrendo há muitos séculos, sua modalidade contemporânea é cada vez mais rápida e intensa, o que leva a uma maior densidade das redes de interdependência, que podem ter consequências profundas sobre outras regiões geográficas, em dimensões militares, políticas, sociais e jurídicas.

Em razão disso, a globalização é acompanhada de uma incerteza constante ${ }^{3}$, sendo imperioso, portanto, pelo menos no campo do direito, que se estabeleçam parâmetros universais, auferíveis por meio dos direitos humanos.

Como se sabe, o Direito Internacional dos direitos humanos é fruto dos efeitos pós- Segunda Guerra Mundial, tendo surgido como forma de resposta aos horrores e atrocidades cometidas pelo regime nazista.

1 LEWANDOSWSKI, Enrique Ricardo. Globalização e Soberania, in Direito Internacional, Humanismo $e$ Globalidade, 2008, p. 293. “A chamada globalização (...) representa uma nova etapa da evolução do capitalismo, tornada possível pelo extraordinário avanço tecnológico nos campos da comunicação e informática, caracterizando-se basicamente pela descentralização da produção, que se distribuiu por diversos países e regiões, a sabor dos interesses das empresas multinacionais. A globalização, todavia, não se resume a esse novo modo de produção capitalista, estrutura em escala mundial. Ela decorre também da universalização dos padrões culturais e da necessidade de equacionamento comum dos problemas que afetam a totalidade do planeta, como a degradação do meio ambiente, a explosão demográfica, o desrespeito aos direitos humanos, a disseminação de doenças endêmicas, a multiplicação de conflitos regionais".

${ }^{2}$ Não é objeto deste trabalho, analisar as diversas teorias acerca dos direitos humanos (jusnaturalista, positivista e realista), para tanto ver Tavares, André Ramos, Curso de Direito Constitucional, 2013. Note-se ainda que para traduzir a noção de direitos humanos existe uma vasta gama de expressões utilizadas. Nos dizeres de Carvalho Ramos, André de ,Direitos humanos na integração econômica. Análise comparativa da proteção de direitos humanos e conflitos jurisdicionais na União Europeia e Mercosul, p. 21: "Os diplomas normativos internacionais contêm uma impressionante variação terminológica, tais como, para citar as mais utilizadas, 'direitos fundamentais', 'liberdades públicas', 'direitos da pessoa humana', 'direitos do homem', 'direitos da pessoa', 'direitos individuais', 'direitos fundamentais da pessoa humana', 'direitos públicos subjetivos' e por fim, a expressão já mencionada 'direitos humanos'.

${ }^{3}$ NEYE JR., Joseph S. Cooperação e conflito nas relações internacionais. Uma leitura essencial para entender as principais questões da política mundial, p.247. 
Baseia-se na concepção de que as nações têm obrigação de respeitar os direitos humanos de seus cidadãos e que as nações da comunidade internacional têm o direito e a responsabilidade de protestar se um Estado descumprir com suas obrigações ${ }^{4}$.

Os direitos humanos ${ }^{5}$, no plano jurídico, segundo o magistério de Celso Lafer, representam, inicialmente, uma inversão da figura deôntica originária, quer dizer, a partir deles houve uma passagem do dever de submissão (ideia ainda presente na palavra ‘administrado', amplamente utilizada em nosso meio jurídico) para o direito do cidadão.

Conforme preceitua Carvalho Ramos ${ }^{6}$ :

"Os direitos humanos consistem em conjunto mínimo de direitos necessário para assegurar uma vida do ser humano baseada na liberdade, igualdade e na dignidade. Justamente por serem essenciais e terem tal finalidade, os direitos humanos diferenciam-se dos demais direitos subjetivos, possuindo hierarquia normativa superior. Do ponto de vista formal, os direitos humanos são aqueles expressos ou garantidos pelas normas superiores de um ordenamento jurídico determinado, essenciais para a existência ou para o conteúdo de outros direitos desse ordenamento (garantias)."

\footnotetext{
${ }^{4}$ BILDER, R. B. Na overview of internacional human rights Law. In: Hannum, H. (editor). Guide of internacional human rights practice, p. $3 / 5$.

${ }^{5}$ SouZA SANTOS, Boaventura. Para uma Concepção Intercultural dos Direitos Humanos, p. 13 "É sabido que os direitos humanos não são universais na sua aplicação. Actualmente são consensualmente identificados quatro regimes internacionais de aplicação de direitos humanos: o europeu, o inter-americano, o africano e o asiático. No entanto, as vicissitudes da aplicação não predeterminam a questão da validade dos direitos humanos, e, de facto, um dos debates mais acesos sobre os direitos humanos gira à volta da questão de saber se os direitos humanos são universais ou, pelo contrário, um conceito culturalmente Ocidental, e, concomitantemente, à volta da questão dos limites da sua validade"
}

${ }^{6}$ Carvalho Ramos, André de. Direitos Humanos na integração econômica, Análise comparativa da proteção de direitos humanos e conflitos jurisdicionais na União Europeia e Mercosul, p. 20. Prossegue o autor "Os direitos humanos estão, em geral, inseridos nas Constituições (norma suprema) ou nos tratados internacionais (compondo obrigações internacionais que devem ser cumpridas pelos Estados). No caso da União Européia e do Mercosul, há dificuldade na delimitação conceitual dos direitos humanos, pois em ambas as organizações internacionais não havia catálogo de direitos expressamente previsto nos tratados originários". 
Para Piovesan, “os direitos humanos compõem, assim, uma unidade indivisível, interdependente e interrelacionada, capaz de conjugar o catálogo de direitos civis e políticos com o catálogo de direitos sociais, econômicos e culturais"”.

Não se há de olvidar que os direitos humanos possuem uma qualidade de jus cogens de direitos fundamentais, que não se limita ao campo teórico: "Tratados internacionais, como os de extradição, podem ser considerados ofensivos ao iuscogens por terem violado direitos fundamentais do extraditando. Mesmo condutas unilaterais dos Estados ou coletivas, adotadas no seio de organizações internacionais podem ser confrontadas com o respeito às normas de iuscogens ${ }^{8}$.

O principal instrumento de proteção a esses direitos é a Declaração Universal dos Direitos Humanos,de 1948, que consolidou valores éticos universais que devem ser seguidos pelos Estados ${ }^{9}$, adotando o valor da primazia da pessoa humana ${ }^{10}$, inspirada na sua dignidade.

${ }^{7}$ PIOVESAN, Flavia. Hierarquia dos tratados internacionais de proteção dos direitos humanos: Jurisprudência do STF, p. 126.

${ }^{8}$ CARVALHO RAMOS. André de, Direitos Humanos na integração econômica. Análise comparativa da proteção de direitos humanos e conflitos jurisdicionais na União Europeia e Mercosul, p. 30.

${ }^{9}$ NA-NA'IN, Abdullahi Ahmed. "Why should Muslims abandon Jihad?Human rights and the future of international law", in International Law and The Third World. Reshaping Justice, p. 86/7. "In fact, the idea of universal rights of all human beings as such was inconceivable before the Charter of the United Nations of 1945, establishment of the United Nations and the consequent process of decolonisation during the subsequent decades. The vast majority of Africans and Asians could not have had any possibility of human rights under European colonialism. Yet those earlier English, French and American documents did in fact shape the 'content' of human rights texts once the idea was established through the UN Charter and the Universal Declaration of Human Rights of 1948. (...) Given the large numbers of Muslims around the world, as not earlier, is clear that one cannot speak of universal human rights without taking into consideration the perspectives and experiences of Islamism societies. (...) The level of compliance with human rights norms is more likely to be associated with such conditions as the degree of political stability and economic and social development in post-colonial Islamic societies than with Islam as such.(...) I find that framing the issue in terms of transforming attitudes and values is more constructive than simplistic assertions of the compatibility or incompatibility of Islam and human rights which take both sides of this relationship in static essentialist terms. This approach is necessary for mediating the paradox of the idea of universal human rights in a world of profound and permanent cultural and contextual difference. Because all human beings are entitled to these rights by virtue of their humanity, without any distinction on grounds of race, sex, religion, language or nation origin, no person should be required to give up any of these essential aspects of his or her identity in order to qualify to these rights".

${ }^{10}$ COMAPARATO, Fabio Conder. A afirmação histórica dos direitos humanos, p. 11. "É a partir do período axial que o ser humano passa a ser considerado, pela primeira vez na História, em sua igualdade essencial, como ser dotado de liberdade e razão, não obstante as múltiplas diferenças (...). Lançava-se, assim, os fundamentos intelectuais para a compreensão da pessoa humana e para a afirmação da existência de direitos universais, porque a ela inerentes". 
"Esta declaração afirmou pela primeira vez, em escala planetária o papel dos direitos humanos na convivência coletiva ${ }^{11}$.

A partir desse marco, surgiram inúmeros tratados internacionais voltados à proteção dos direitos humanos, sendo certo afirmar que, atualmente, há um sistema global e diversos sistemas regionais de proteção aos direitos humanos, atuando de forma complementar $^{12}$. Como exemplos: Pacto Internacional de Direitos Civis e Políticos, Pacto Internacional de Direitos Econômicos, Sociais e Culturais (ambos adotados pela Assembleia Geral da ONU), Convenção Europeia de Direitos Humanos, Convenção Americana de Direitos Humanos, Carta Africana de Direitos do Homem e dos Povos, entre outros.

Esses tratados internacionais compõem, atualmente, corpus juris autônomos de tutela - que não são estáticos e se atualizam com o passar do tempo ${ }^{13}$ - dotados de especialidade e de princípios próprios, tendo se desenvolvido como resposta às violações e desrespeitos a vários direitos humanos. ${ }^{14}$

$\mathrm{Na}$ época atual, existe uma alentadora multiplicidade de tribunais contemporâneos internacionais, reveladora dos consideráveis avanços na busca da realização do ideal da

\footnotetext{
${ }^{11}$ LAFER, Celso. Declaração Universal dos Direitos Humanos (1948), p. 297 e 320: "A Declaração Universal, desde a sua origem, traçou uma política de direito para o desenvolvimento do Direito Internacional dos Direitos Humanos. O preâmbulo da Declaração de Viena reconhece e realça a importância desta política de direito da Declaração universal, pois, como foi visto, nela se identificam a 'fonte de inspiração' e a base utilizada pelas Nações Unidas para o progresso das normas internacionais de direitos humanos. Esta política do Direito foi sendo efetivamente levada adiante, pois a Declaração Universal teve o mérito de não ser apenas uma reação aos problemas do passado. Projetou valorações fundamentais para modelar o futuro. (...). Neste sentido, a Declaração Universal é um bem sucedido paradigma daquilo que, depois da Segunda Guerra Mundial e graças ao multilateralismo diplomático, tornou-se usual no processo de criação de normas de Direito Internacional Público. [...]. Os dois grandes instrumentos de proteção geral são os Pactos aprovados pela Assembléia da ONU em 16/12 de 1966l; O Pacto Internacional sobre Direitos civis e Políticos e o Pacto Internacional dos Direitos Econômicos, Sociais e Culturais que entraram em vigor, respectivamente, em 23/3/1976 e 3/1/1975.
}

\begin{abstract}
${ }^{12}$ TRINDADE, Antonio Augusto Cançado. A humanização do direito internacional, p. 399. "Em meados do século XX reconheceu-se a necessidade da reconstrução do direito internacional com atenção aos direitos do ser humano, do que deu eloqüente testemunho a adoção da Declaração Universal de 1948, seguida, ao longo de cinco décadas, por mais de 70 tratados de proteção hoje vigentes nos planos global e regional. Na era das Nações Unidas consolidou-se, paralelamente, o sistema de segurança coletiva, que, no entanto, deixou de operar a contento em razão dos impasses gerados pela guerra fria. O direito internacional passou a experimentar, no segundo meado deste século, uma extraordinária expansão, fomentada em grande parte pela atuação das Nações Unidas e agências especializadas, ademais das organizações regionais".
\end{abstract}

${ }^{13}$ PRONER, Carol. Os Direitos Humanos e seus paradoxos: Análise do Sistema Interamericano de Proteção, p. 41.

${ }^{14}$ MAZZUOLI, Valério de Oliveira. Tratados Internacionais de Direitos Humanos e Direito Interno, p. 27. 
justiça internacional ${ }^{15}$. Assim, "a proteção dos direitos humanos torna-se fator-chave para a convivência dos povos na comunidade internacional". 16

Embora a globalização possua caráter planetário, a integração regional e subregional, muito popular nas décadas de 1950 e 1960, surgiu como forma de impedir a retomada dos conflitos que levaram à ocorrência da Primeira e Segunda Guerra mundiais e como forma de proteção a aspectos negativos que ela encerra ${ }^{17}$. Em 1950, a Europa deu início a esse processo com o Plano Schuman ${ }^{18}$, tendo sido criado, em 1957, o Mercado Comum Europeu $^{19}$. Outras regiões também aderiram ao regionalismo, ainda que, no caso da América Latina, ainda se encontre em fase embrionária.

Não se há de olvidar que, dentre os principais órgãos do sistema regional de proteção dos direitos humanos, encontram-se a Corte Europeia de Direitos Humanos e a Corte Interamericana de Direitos Humanos.

O Brasil é integrante da Corte Interamericana de Direitos Humanos que, não obstante as inúmeras dificuldades quanto à implementação de suas decisões e críticas quanto à impossibilidade de acesso direto da vítima, constitui um avanço na proteção desses direitos que, além de representarem posições contrárias majoritárias, possuem inegável força e geografia expansiva.

\footnotetext{
${ }^{15}$ TRINDADE, Antonio Augusto Cançado. op. cit., p. 405.

${ }^{16}$ CARVALHO RAMOS, André de, Processo Internacional dos Direitos Humanos. Análise dos sistemas de apuração de violações dos direitos humanos e a implementação das decisões no Brasil, p. 19.

${ }^{17}$ LEWADOSWSKI, Enrique Ricardo, Globalização e Soberania, op. cit., p. 294.

${ }^{18}$ ROCHA, Luiz Alberto G.S. Estado, Democracia e Globalização, p. 117. "O sumo do documento era uma proposta de aliança franco-germânica, mas aberta a outros países europeus, para controle supranacional do carvão e aço. [...] A grande novidade na Declaração de Schuman era que ela, pelas justificativas acima, superava o ritmo então imposta na estrutura européia e do Direito Internacional de modo geral, porque propunha a formação de um berço integrativo com a criação de uma entidade supranacional (a Alta Autoridade) para coordenar a ação do comércio dos produtos envolvidos. [...] Ela iniciava exaltando a encruzilhada que a Europa vivia: 'a paz mundial não será salvaguardada sem esforços criadores a altura dos perigos que a ameaçam', Os esforços que deveriam ser feitos_eram de gerenciamento da parte da economia dos Estados mesmo que essa posição viesse a atentar contra a soberania dos envolvidos. [...] 'Para a conjunção da produção de base e para a instituição de uma nova Alta Autoridade, cujas decisões vincularão a França, a Alemanha e aqueles países que aderirem, essa proposição realizará as primeiras bases concretas de uma Federação européia indispensável à preservação da paz"”.

${ }^{19}$ NYE JR., Joseph S. op. cit., p.309/10. "O membros da EU escolheram aumentar sua interdependência complexa na crença de que a relação custo/benefício favorece a cooperação sobre a interdependência nacional plena. Na Europa atual, todo mundo pode não estar no mesmo barco, mas os barcos partiram juntos em diversos rumos e são muito diferentes daqueles dos períodos iniciais. Por exemplo, em muitas regiões da EU a legislação atual se sobrepõe à legislação nacional. A União Européia representa um novo tipo de política internacional, mas não passa de uma expressão regional".
} 


\subsection{Política externa brasileira no mundo globalizado e cooperação jurídica internacional em matéria penal.}

Inicialmente, é preciso ver que a globalização e a cooperação internacional (jurídica ou não) não podem ser analisadas de forma dissociada da política (interna e externa), da economia e da cultura, vivenciadas pelos países soberanos ao longo da história.

Sabe-se que o ser humano - seus desejos, anseios e sua relação com a sociedade sofre, ao longo do tempo, infinitas mutações que ${ }^{20}$ modelam o padrão jurídico seguido pelas nações no decorrer da história, segundo $\operatorname{Passos}^{21}$ :

"A sociedade que no presente nos influencia e modela não existiu sempre e necessariamente como ela é hoje e o que é agora foi resultado de muitas opções humanas que teceram, ontem, a rede de comunicações que a constitui. Destarte, também a sociedade de amanhã vai depender de nossas opções no presente, pelo que estamos sempre em condições de fazer com que as coisas mudem, sempre aptos a remodelar a sociedade que moldará nossos filhos, e somos responsáveis por isso.”

O fenômeno da cooperação jurídica internacional não é novo, remonta ao antigo Oriente, havendo notícia de tratado de extradição entre o Egito e os Ititas ${ }^{22}$, tendo, entretanto, se desenvolvido de forma acelerada nas últimas décadas, em especial diante na nova realidade política e econômica mundial.

\footnotetext{
${ }^{20}$ NOGUEIRA, Alberto. Viagem ao Direito do Terceiro Milênio. Justiça, Globalização, direitos humanos e tributação, p. 170. "Já se sabe, isso é muito antigo, está na Bíblia, SALOMÃO já dizia 'nihilnovi sub sole' nada de novo sob o sol -, mas a novidade não está na coisa em si, a novidade está em nós mesmos. Nós nos redescobrimos a cada instante, e o mundo, sendo ele próprio o mesmo, se altera numa dinâmica fantástica. Logo essa relação entre o ser humano, o mundo e a realidade, é ininterrupta e as transformações, as mutações as metamorfoses, que presidem esse misterioso processo, são infindáveis. Por isso mesmo é que o jurista, o operador do Direito, de um modo geral, seja Juiz, Professor, estudante, Advogado, Promotor ou Defensor, não importa a desalinha equação, está comprometido dentro dessa realidade, e se ele não puder entender essas sutis nuances, ele tende, como tudo que se torna estático, a desaparecer como algo realmente vivo".
}

${ }^{21}$ PASSOS, Calmon de. Direito, poder, justiça e processo. Julgando os que nos julgam, p. 43/4.

${ }^{22} \mathrm{NEFF}$, Stephen C. A Short history of International Law, p.33. 
$\mathrm{Na}$ atualidade, ocorre uma aceleração brutal no processo conhecido como globalização, com o avanço vertiginoso das comunicações e da tecnologia. Isso, sem sombra de dúvida, propiciou a criação de um mercado quase que universal, surgindo a necessidade de criação de blocos regionais e sub-regionais, tentando se proteger da hegemonia uns dos outros.

O fim da Guerra Fria ${ }^{23}$ facilitou a criação de acordos internacionais, na medida em que não havia mais a dicotomia do bloco soviético com o bloco ocidental, embora isso não tenha determinado o início da globalização, nem sua aceleração, foi responsável pela crescente necessidade dos países de cooperarem em diversos graus.

Conforme esclarece Guerra ${ }^{24}$ :

"De fato, o fenômeno da globalização engendrou um novo quadro na economia mundial, delineado por uma dominação pelo sistema financeiro e pelo investimento elevado à escala global; processos produtivos flexíveis e multilocalizados; desregulação das enconomias nacionais; revolução nas tecnologias de informação e comunicação; baixos custos dos meios de transporte; projeção das agências financeiras multilaterais; emergência dos modelos transnacionais de capitalismo americano, japonês e europeu.

Continua o autor:

“O reflexo dessas transformações no sistema mundial varia em grau conforme seja a posição ocupada por um Estado no sistema mundial. Contudo, é inegável a grandeza das consequencias para a construção das políticas economicas nacionais, especialmente nos países

\footnotetext{
${ }^{23}$ CANÇADO TRINDADE, Antônio Augusto. A Humanização do Direito Internacional, p. 91. "As notáveis transformações no cenário mundial desencadeadas a partir de 1989, pelo fim da guerra fria e a irrupção de numerosos conflitos internos, caracterizam os aos noventa como um momento na história contemporânea marcado por uma profunda reflexão, em escala universal, sobre as próprias bases da sociedade internacional e a formação gradual da agenda internacional do século XXI. O ciclo das Conferências Mundiais das Nações Unidas do final do século XX tem procedido a uma reavaliação global de muitos conceitos à luz da consideração de temas que afetam a humanidade como um todo".
}

${ }^{24}$ GUERRA, Sidney. Direitos Humanos. Curso Elementar, p. 316 
periféricos ou semiperiféricos (emergentes), [...]. Em linhas gerais, tornam-se comuns expressões como 'enxugar o Estado', 'flexibilização', neoliberalismo'. O Estado fica limitado na capacidade de regulação da economia; surgem novos direitos de propriedade internacional para investidores estrangeiros, investores e subordinação dos Estados nacionais às agências multilaterais (FMI, Banco Mundial, OMC)."25

Os mercados unificaram-se em grande medida e isso suscitou a criação de mais regras multilaterais, bilaterais ou ainda de reciprocidade (baseada na confiança), podendo-se dizer que o direito volta-se para a necessidade de entendimento do que cada uma dessas nações tem sobre o que é a democracia plena, democracia com direito contraditório, ampla defesa, valores comuns a todos eles, mais fortemente em uns do que em outros, devido às divergências sociais, econômicas, culturais e geopolíticas.

Destarte, para que se tenha uma legislação supranacional efetiva à luz de opções políticas dos Estados membros, é preciso compatibilizar seus interesses com a necessidade de se criar e harmonizar a legislação que abrigue o comércio entre as nações, o respeito aos direitos humanos, o reconhecido por cada um dos membros, dentre outras coisas.

Nesse sentido, não se há de negar que o Direito acompanha os entendimentos políticos e deles decorre, enquanto os tratados internacionais ${ }^{26}$ são resultado do esforço dos países de compatibilizar suas legislações com as realidades próprias, ainda que isso suscite alguns conflitos de complexas soluções, devido à noção de soberania.

Em cada nação existem interesses concretos econômicos, políticos, sociais, com muitos conflitos, de modo que, é claro, os acordos internacionais - assim como a intensificação da cooperação entre os Estados (em diversos níveis) - representam um avanço, na medida em que eles exprimem as contradições de cada país e as pressões da sociedade para ter uma participação maior no negócio do bloco econômico mundial. Além disso, associam-se

\footnotetext{
${ }^{25}$ Id., p.317.

${ }^{26}$ Id, p.84. "Tratado é um termo genérico que pode servir para designar um acordo entre dois ou mais Estados para regular um assunto, determinar seus direitos e obrigações, assim como as regras de conduta que devem seguir, mas em nenhum caso é aplicável a um acordo entre um Estado e uma pessoa privada". Ver também Convenção de Viena sobre o direito dos tratados (Decreto 7.030/09) e Convenção de Havana sobre Tratados (Decreto 18.956/29).
} 
à formação de novas leis, mais adequadas à modernidade (não se esquecendo de que tais leis, em grande parte, decorrem da vontade da elite, mas influenciada pelas classes sociais menos favorecidas).

É diante desse contexto que se deve situar e compreender as ideias jurídicopolíticas que almejam garantir a nova forma de coexistência mudial, tentando compatilizar e harmonizar as legislações. Trata-se, sem dúvida, de uma tarefa árdua, que só avança na medida em que os interessses vão convergindo para a criação de leis mais homogêneas e harmônicas e de cortes internacionais que procuram decidir acima das nações.

Nesse diapasão, conforme assentou Canotilho:

“[...]os limites jurídicos impostos ao Estado advêm também, em medida crescente, de princípios e regras jurídicas internacionais. Estes princípios e regras estão, em grande número, recebidos ou incorporados no direito interno fazendo parte of the land (CPR, artigo 8\% e 2). Nenhum Estado pode permancer out, isto é, fora da comunidade internacional. Por isso, ele deve submeter-se às normas de direito internacional, quer nas relações internacionai quer no próprio actuar interno. A doutrina mais recente acentua mesma a amizade e a abertura ao direito internacional como uma das dimensões do Estado de direito.",27

No cenário da nova realidade mundial, em especial, do aumento da criminalidade global, da violência e da sensação de insegurança, surge, cada vez mais, uma necessidade de cooperação jurídica entre os Estados e de uma normatização ${ }^{28}$ da assistência jurídica internacional em matéria penal, de forma a compatibilizar os interesses dos diversos Estados

\footnotetext{
${ }^{27}$ CANOTILHO, J. J. Gomes. Direito Constitucional e Teoria da Constituição, $7^{\mathrm{a}}$ ed., Coimbra: Almedina, 2003, p. 232.

${ }^{28}$ Esta normatização, além da observância dos costumes e princípios do direito internacional, poder ocorrer por meio das hard law ou mesmo das soft law, embora estas últimas não possuam caráter vinculativo, constituem normas em transito para a normatização da postura internacional sobre a matéria.
} 
soberanos em reprimir a criminalidade, que ultrapassa as barreiras nacionais, e de garantir o respeito aos direitos humanos fundamentais.

Na conjuntura atual do Brasil, pode-se dizer que: (i) o aumento do contingente de brasileiros no exterior; (ii) os novos contornos da inserção internacional do país (que também provocam aumento dos pedidos de cooperação judiciária); (iii) a preocupação renovada do Governo e da sociedade com o combate ao crime de caráter transnacional e à impunidade de criminosos importantes; e (iv) a atenção singular de casos específicos, de significado político, que envolvem a cooperação jurídica entre o Brasil e terceiros Estados, demonstram a importância da cooperação jurídica na agenda externa do país ${ }^{29}$.

De fato, parafraseando Valladão ${ }^{30}$, o Brasil sempre encarou com elevado espírito de solidariedade o dever que incumbe aos vários Estados de se auxiliarem reciprocamente, de forma solidária, na repressão aos crimes.

Tanto que a Carta política brasileira erigiu como um dos princípios que regem as relações internacionais do país a cooperação entre os povos para o progresso da humanidade, juntamente com os princípios da independência nacional, da prevalência dos direitos humanos, da autodeterminação dos povos, da não intervenção, da igualdade entre os Estados, da defesa da paz, da solução pacífica dos conflitos, do repúdio ao terrorismo e ao racismo, da concessão de asilo político ${ }^{31}$.

Via de regra, a cooperação internacional no país desenvolveu-se pela diplomacia $^{32}$ - podendo ocorrer por meio de tratados bilaterais e multilaterais ${ }^{33}$, ou não socorrendo-se dos costumes e princípios do Direito Intenacional, direito que se interessa em

\footnotetext{
${ }^{29}$ KLEEBANK, Susan. Cooperação Judiciária por via diplomática. Avaliação e propostas de atualização do quadro normativo, p. 16.

${ }^{30}$ VALLADÃO, HAROLDO. Direito Internacional Privado. Rio de Janeiro: Freitas Bastos, Volume III.

${ }^{31}$ Ver art. $4^{\text {o }}$, incisos I ao X, da CF/88 e parágrafo único.

${ }^{32}$ Ver Convenção de Viena sobre as relações diplomáticas (Decreto 56.435/65) Convenção de Viena sobre as relações consulares (decreto 61.078/67).

${ }^{33}$ GUERRA, Sidney. Curso de Direito Internacional Público, p. 83. "Diferentemente do que acontecia no passado, os tratados internacionais são considerados a principal fonte do Direito Internacional. Ao ser concebida uma norma escrita no plano internacional (tratado), evidencia-se maior segurança jurídica n âmbito das relações internacionais, principalmente se se levar em conta que no passado a principal fonte do Direito Internacional Público era o costume. A sociedade internacional se apresentava de forma estática e hodiernamente se apresenta de forma dinâmica".
} 
proteger o homem contra qualquer indevida restrição que se faça à sua liberdade ${ }^{34}$ e a seus princípios, tais como da reciprocidade, da confiança e da solidariedade ${ }^{35}$.

Entretanto, conforme explicita Kleebank ${ }^{36}$ :

"A experiência demonstra que, na ausência de moldura normativa apropriada, gestões diplomáticas muitas vezes têm sido insuficientes para garantir o cumprimento de solicitações de cooperação judiciária. Além disso, a existência de instrumentos internacionais tende a fortalecer a posição de requerente do Brasil em situações em que não haja interesses específicos na cooperação judiciária bilateral por parte do país solicitado."

O acréscimo da necessidade de cooperação entre os diversos Estados, em todos os campos, conduz a uma nova leitura do Direito Internacional ${ }^{37}$ e à elaboração de normas jurídicas que, na defesa dos interesses de cada nação, objetivam a regulamentação dessas complexas relações, desenvolvidas em uma constelação de Estados.

Conforme preleciona Araújo $^{38}$, a Cooperação Jurídica Internacional tem sido objeto de negociações internacionais, visando o estabelecimento de regras uniformes para a matéria. Trata-se de normas convenientes por garantirem maior rapidez e eficácia no cumprimento das medidas provenientes de outros países ou endereçadas ao estrangeiro.

Os tratados internacionais ${ }^{39}$, bilaterais ou multilaterais, relativos à cooperação jurídica internacional conferem maior segurança aos Estados e aos jurisdicionados. Segundo

\footnotetext{
${ }^{34}$ ALBUQUERQUE MELlO, Celso D. de, Curso de Direito Internacional Público, p. 907.

${ }^{35}$ Ver art. $3^{\circ}$, inciso I, da CF/88. “Art. $3^{\circ}$ Constituem objetivos fundamentais da República Federativa do Brasil, I - constituir uma sociedade livre, justa e solidária".

${ }^{36}$ KLEEBANK, Susan. Cooperação (...), op. cit., p. 19.

${ }^{37}$ GUERRA, Sidney. Curso de Direito Internacional Público, p.75. "O direito internacional contemporâneo já não tem apenas a função clássica de regular as relações entre Estados soberanos, mas, sim, procura atuar no desenvolvimento da sociedade internacional, que comtempla vários novos atores, a próxima inserção do indivíduo no campo internacional onde há um grande envolvimento da ordem jurídica internacional e interna".

${ }^{38}$ ARAÚJO, Nadia (coord.). Cooperação Jurídica Internacional no Superior Tribunal de Justiça: Comentários à Resolução $n^{o}$ 9/2005, p.3.

${ }^{39}$ Ver artigo $2^{\circ}$, inciso I, da Convenção de Viena, Decreto 610788/67: “O estabelecimento de relações consulares entre Estados far-se-á por consentimento mútuo".
} 
$\operatorname{Rezec}^{40}$, "o acordo formal entre Estados é o ato jurídico que produz a norma, e que, justamente por produzi-la, desencadeia efeitos de direito, gera obrigações e prerrogativas”.

Nos dizeres de Cançado Trindade, os tratados internacionais, multilaterais e bilaterais, têm angariado adeptos:

\begin{abstract}
“Certamente que a multilaterização dos contatos internacionais é um fenômeno hodierno da maior importância e muitos Estados têm identificado no multilateralismo um fator até certo ponto compensador ou neutralizador de suas desigualdades de poder no cenário internacional. O multilateralismo acompanhou naturalmente a ascensão e a expansão dos organismos internacionais. Em nosso continente, há os que hoje vislumbram um gradual distanciamento do bilateralismo do passado (que se mostrava defensivo, como produto da confrontação), e uma crescente tendência a atribuir maior importância ao multilateralismo paralelamente ao surgimento de interlocutores 'viáveis' vis-à-vis à superpotência na região (como v.g., Argentina, Brasil, México e Venezuela)."
\end{abstract}

O ascendente desejo de cooperação entre os Estados afeta a geografia e a geometria do direito internacional ${ }^{42}$. Na Europa, com o entendimento político entre a França e a Alemanha, foi possível criar o Mercado Comum Europeu, existindo a formação de uma comunidade europeia representativa do processo de integração supranacional mais ousado e complexo que já se conheceu ${ }^{43}$.

Aludido mercado comum prevê a compatibilização das políticas econômicas, trabalhistas, cambiais, tributárias, para que se tenha uma zona de livre comércio, ainda que

\footnotetext{
${ }^{40}$ REZEC, José Francisco. Direito Internacional Público. Curso Elementar, p.42.

${ }^{41}$ TRINDADE, Antônio Augusto Cançado. Direito das organizações internacionais, p. 433.

${ }^{42}$ ALBUQUERQUE MELlO, Celso D. Curso de Direito Internacional Público, p. 48 "O direito internacional foi durante longo tempo interestatal e ainda se apresenta, apesar das atenuações, predominantemente sob este aspecto. A sua moderna configuração nasceu na Europa Ocidental em época em que os grandes Estados Nacionais já estavam formados. É assim o Estado o seu membro originário e principal sujeito”.
}

${ }^{43}$ SOUZA SILVA, Karine de. Direito da Comunidade Europeia, Fontes, Princípios e Procedimentos, p. 25. 
durante algum tempo contemple preferências de tratamento diferenciado para alguns membros menos desenvolvidos como maneira de fazer o bloco econômico.

A União Europeia constrói-se a partir de duas formas jurídico-políticas distintas - a integração comunitária e a cooperação intergovernamental -, dispondo de uma norma jurídica autônoma, o direito comunitário ${ }^{44}$ que visa facultar aos cidadãos um elevado nível de proteção em um espaço de liberdade, segurança e justiça:

“A criação de um grande mercado económico europeu e a construção de um espaço europeu sem fronteiras entre os Estados-Membros, com a livre circulação de mercadorias, de capitais e de serviços e, naturalmente, também de pessoas, são, sem mais condições 'óptimas' de desenvolvimento e expansão de uma criminalidade cujas características principais são exatamente a orga." 45

Por sua vez, nos países da América Latina, há a formação de zonas livres de comércio que diferem do Mercado Comum Europeu. É o caso do Brasil e da Argentina, em que Estados recentemente democratizados decidiram se reaproximar, mesmo diante da existência de uma rivalidade histórica, com a percepção da necessidade de um entendimento entre eles, quer no campo bélico, quer no militar, econômico e político, para a futura formação do MERCOSUL ${ }^{46}$.

Com o tempo, foram elaborados tratados, tornando possível, inclusive, a entrada de outros países não integrantes do Cone Sul. Existem países que não pertencem ao

\footnotetext{
${ }^{44}$ MACHADO, Maíra Rocha. Internacionalização do direito penal. A gestão de problemas internacionais por meio do crime e da pena, p. 53.

${ }^{45}$ PASSOS, Calmon de, Direito, poder, justiça e processo. Julgando os que nos julgam, p. 43/4.

${ }^{46}$ VervaELE, John A. E. O Mercosul e a integração regional na América Latina, p. 251/2. Nas últimas duas décadas, a Europa e os Estados Unidos da América fizeram grandes investimentos na América Latina. O processo de democratização nessa região, especialmente nos países marcados por uma tradição de ditadura limitar, reforça a confiança em sua estabilidade política e econômico. A cooperação política e econômica entre os países marcados por uma tradição de ditadura militar, reforça a confiança em sua estabilidade política e econômica. A cooperação política e econômica entre os países está ocupando o lugar da rivalidade política e militar. AS propostas da Agentina e Brasil levaram, em 1991, ao estabelecimento do Mercosul. Sua importância econômica - o MERCOSUL é o quarto maior bloco econômico do mundo, depois dos EUA, da União Europeia (EU) e do Japão - e política foi reconhecia a tempo pela EU. Já em 1995 foi concluído um acordomarco inter-regional para a cooperação entre os Estados Membros da EU e os Estados Partes do Mercosul".
} 
MERCOSUL, que são apenas observadores, mas solicitam seu ingresso, como é o caso do Chile.

O embaixador Samuel Pinheiro Guimarães (apud TACHINARDI, ${ }^{47}$ ) esclarece que o programa de integração de cooperação:

“[...] levaria ao Tratado de Integração Brasil - Argentina, que definia um projeto de desenvolvimento econômico, a partir da integração dos sistemas produtivos industriais. As ideias-chaves (sic) desse Programa de Integração Brasil-Argentina, que definia um projeto de desenvolvimento econômico a partir da integração dos sistemas produtivos industriais. As ideias-chaves (sic) desse Programa de Integração Brasil-Argentina eram o equilíbrio dinâmico, a participação empresarial, o gradualismo. O Mercosul viria, por outro lado e mais tarde, a ser um projeto de concepção neoliberal de integração apenas comercial, apenas um instrumento para acelerar a redução geral de tarifas dos dois países em relação ao mundo, em um processo que se chamou e "regionalismo aberto."

Analisando a política externa brasileira, prossegue o embaixador:

'Na América do Sul, as relações do Brasil com os países do Mercosul são vitais. No Mercosul, nossas relações com a Argentina, com quem partilhamos um passado de disputas, um presente misto de admiração e rivalidade, o futuro é de união inevitável. A importância do Brasil para a Argentina e da Argentina para o Brasil se revela pelo comércio bilateral, que passou de US\$ bilhões em 1986 para US\$ 30 bilhões em 2008 e em que 90\% são produtos manufaturados, e por uma infraestrutura e uma estreita coordenação política no âmbito regional, interamericano e internacional, em foros como o Unasul - União das Nações Sul-Americanas -, a OEA - Organização dos Estados

\footnotetext{
${ }^{47}$ Citado por TACHINARDI, Maria Helena. Roberto Müller Filho, Intuição, Política e Jornalismo, p. 159.
} 
Americanos -, a OMC - Organização Mundial do Comércio -, o G-20, o FMI e as Nações Unidas." 48

Pode-se dizer, de forma sucinta, que o MERCOSUL ${ }^{49}$ foi uma tentativa de os países do cone Sul se defenderem como bloco da hegemonia do mercado americano, que é muito forte. Decorre da necessidade de se criar um mercado mais amplo, tanto quanto possível isento de barreiras tarifárias e não tarifárias e da necessidade de tratar os mercados desses países, na medida do possível, de modo unificado, frente ao jogo de aproximações, de conquistas progressivas que decorrem dos avanços econômicos e políticos em cada um dos países, ou em cada um dos blocos econômicos.

Para a maioria dos doutrinadores, o direito no MERCOSUL não constitui uma organização supranacional, embora disponha de personalidade jurídica (art. 34 do POP), o que permite à CMC concluir tratados em seu nome. A estrutura orgânica do bloco é de uma organização intergovernamental com objetivos comunitários ${ }^{50}$.

De acordo com Carvalho Ramos ${ }^{51}$ :

“O Mercosul está lutando com o dilema entre objetivos comunitários e instrumentos intergovernamentais.[...]A entrada em vigor do Mercosul é demasiadamente complexa e depende, em excesso, dos procedimentos internos e das agendas dos Estados partes. Devido à

\footnotetext{
${ }^{48}$ Idem, p.161/2.

${ }^{49}$ VERVAELE, John A. E. O Mercosul e a integração regional na América Latina, p. 257/8. "Durante a segunda metade da década de 1980 começaram as negociações entre Brasil e Argentina, os dois maiores atores do continente, relativas à integração regional comunitária. Pretendia-se aprofundar o processo de integração partindo da ALADI como acervo. As negociações deram como resultado em 1991 o Tratado de Assunção (TA). Também acederam países altamente dependentes do ponto de vista econômico, com Uruguai e Paraguai. No transcurso da década de 1990 Bolívia e Chile se converteram em membros associados com base em um acordo relativo a zona de livre mercado com Mercosul. Venezuela, Equador e Colômbia ingressaram no MERCOSUL como membros associados em 2004. Em dezembro de 2005 os países do MERCOSUL aceitaram oficialmente a solicitação da Venezuela para fazer parte do MERCOSUL. O MERCOSUL está baseado em um tratado internacional que estabelece instituições intergovernamentais e fixa objetivos que são todos eles bastante familiares: a realização de uma união aduaneira e de um mercado comum, unido às quatro liberdades. Também tem áreas de política comum e a harmonização que isso implica. Como tal é uma estrutura intergovernamental com um projeto comunitário de integração em mente, dito de outro modo, claramente não limitado a uma associação de livre mercado".
}

${ }^{50}$ VERVAELE, John A. E., O Mercosul e a Integração Regional da América Latina, p. 262.

${ }^{51}$ Id., p. 209/1. 
falta de reconhecimento do efeito direto ao direito do Mercosul, a posição jurídica dos sujeitos em direito nacional é fraca. $\mathrm{O}$ direito no Mercosul não dispõe de nenhum instrumento para obrigar ao cumprimento, nem aos Estados partes nem às instituições do Mercosul, nem aos sujeitos de direito."

Conforme dispõe o artigo $1^{\circ}$ do Tratado de Assunção (Decreto 350/91), o Mercado Comum do Sul implica "o compromisso dos Estados-Partes de harmonizar" suas legislações, nas áreas pertinentes, para lograr o fortalecimento do processo de integração", fundando-se o mercado comum na reciprocidade de direitos e obrigações entre os EstadosPartes (art. $2^{\circ}$, do Tratado).

A cooperação jurídica no âmbito do MERCOSUL vem crescendo intensamente nos últimos tempos. Conforme informações do sítio da internet do Ministério da Justiça:

“[...]em apenas sete meses de 2012, a Secretaria Nacional de Justiça do Ministério da Justiça (SNJ/MJ) tramitou $70 \%$ de pedidos de cooperação jurídica envolvendo países do Mercosul em relação ao total do ano anterior. Ao longo de todo o ano de 2011, tramitaram 863 pedidos de cooperação jurídica. Entre janeiro e julho deste ano, foram feitos 603 pedidos. Os números demonstram que o Brasil mais requisita a cooperação dos outros países do bloco do que é requisitado. “ [ ...] "A atuação na busca de provas e na efetivação de atos processuais no exterior explica alto número de pedidos de cooperação jurídica internacional feitos pelas autoridades brasileiras', afirma o diretor do Departamento de Recuperação de Ativos e Cooperação Jurídica Internacional, Ricardo Saadi." ${ }^{, 53}$

\footnotetext{
${ }^{52}$ RAMOS, André de CaRvalho. Direitos Humanos na Integração Econômica, Análise comparativa da proteção de direitos humanos e conflitos jurisdicionais na União Européia e Mercosul, p . 307 "o método de harmonização busca coordenar as diversas legislações nacionais, estabelecendo metas o que deixa os Estados livres para escolher os meios para cumprir tais princípios, inclusive por meio de fixação de metas mais elevadas. Um dos instrumentos da possíveis da harmonização consiste na preservação dos diversos diplomas normativos sobre a mesma matéria nos diferentes Estados".

${ }^{53}$ portal.mj.gov.br
} 


\subsection{Relação entre direitos humanos e direito interno brasileiro: padrão normativo para cooperação jurídica internacional.}

Observe-se que foi por meio do processo de redemocratização que o Brasil se abriu para o direito internacional dos direitos humanos ${ }^{54}$. Desde a Constituição Federal, de 1988, presenciou-se no país uma busca pelo bloco de constitucionalidade desses direitos ${ }^{55}$. A partir de 2004, com a promulgação da emenda Constitucional 45 (que introduziu o parágrafo $3^{\circ}$ do art. $5^{\circ}$, da $\mathrm{CF} / 88$ ), os tratados internacionais de direitos humanos passaram a ser aprovados por rito especial e ganharam a estatura de norma constitucional.

Note-se que a promulgação da emenda constitucional 454/2004 "estimulou a revisão da jurisprudência do STF sobre os tratados internacionais de direitos humanos" ${ }^{56}$. O novo posicionamento adotado pelo Supremo mitigou inúmeras divergências acerca do conflito entre as normas internas e a norma internacional, embora não tenha solucionado a questão em sua integralidade.

A relação das normas internacionais com o direito interno brasileiro nunca se deu de forma serena, tendo surgido inúmeros problemas quanto à implementação dessas normas no direito interno, conforme se observa de precedentes do Supremo Tribunal Federal. Tornase necessário, destarte, uma análise desta relação.

\footnotetext{
${ }^{54}$ PRONER, Carol. Os Direitos Humanos e seus paradoxos: Análise do Sistema Americano de Proteção, p. 30. "Nesse contexto de universalização de direitos dos humanos e padronização de procedimentos e mecanismos internacionais de proteção, têm sido freqüentes os debates entre internacionalistas, cientistas políticos, filósofos, economistas, economistas, enfim, pensadores que se interessam pelo tema dos direitos humanos e que passa a se preocupar com aspectos pontuais desse processo: o questionamento do papel Estado-Nação, a polêmica universalismo versus multiculturalismo dos direitos humanos, e a necessidade (ou não) da constituição de um governo global dirigido pelas Nações Unidas. O tradicional modelo de Estado tem sido questionado por sua suposta incapacidade, em proteger e promover efetivamente os direitos humanos. Muitos são os críticos do chamado welfarewstate. Seus principais argumentos centram-se na incapacidade estrutural de um Estado quando se trata de garantir direitos em razão da complexa interdependência de fenômenos e processos que atinge a todos os Estados, em todo o globo. A chamada globalização não seria compatível com o modelo tradicional de Estado".

${ }^{55}$ DIREITO, Carlos Alberto. O Estado Moderno e a Proteção dos Direitos do Homem, p.216.“A história da proteção dos direitos do Homem está vinculada diretamente à formulação do regime constitucional. Não resta a menor dúvida que a vitória do constitucionalismo representou o passo mais avantajado na direção do aperfeiçoamento desta proteção.

${ }^{56}$ RAMOS, André de Carvalho. O diálogo das Cortes: O Supremo Tribunal Federal e a Corte Interamericana de Direitos Humanos, p. 805.
} 
Antes da Emenda Constitucional 45/2004, o Supremo Tribunal Federal posicionava-se no sentido de que os tratados internacionais incorporados ao direito interno equiparavam-se à legislação ordinária (RE 80.004).

Não se acolhia, quiçá sob a influência de visões ultrapassadas do conceito de soberania $^{57}$, a ideia de que os tratados internacionais de direitos humanos tivessem tratamento diverso dos demais tratados, no que se refere à sua incorporação no ordenamento jurídico interno ${ }^{58}$.

Entretanto, o novo parágrafo $3^{\circ}$ do art. $5^{\circ}$ da Constituição é considerado "como uma lei interpretativa destinada a encerrar as controvérsias jurisprudenciais e doutrinárias suscitadas pelo parágrafo $2^{\circ}$ do art. $5^{\circ}$. De acordo com a opinião doutrinária tradicional, uma lei interpretativa nada mais faz do que declarar o que pré-existe, ao clarificar a lei existente.

Segundo Lafer ${ }^{59}$ :

“[...] Este me parece ser o caso do novo parágrafo $3^{\circ}$ do art. $5^{\circ}$. Com efeito entendo que os tratados internacionais de direitos humanos anteriores à Constituição de 1988, aos quais o Brasil aderiu e que foram validamente promulgados, inserindo-se na ordem jurídica interna, têm hierarquia de normas constitucionais, pois foram como tais formalmente recepcionada pelo $\S 2^{\circ}$ do art. $5^{\circ}$ não só pela referência nele contida aos tratados como também pelo dispositivo que afirma que os direitos e garantias expressos na Constituição não excluem outros decorrentes do regime e dos princípios por ele adotados. Neste sentido, aponto que a referência aos princípios pressupõe, como foi visto, a expansão axiológica do Direito na perspectiva 'ex parte civium' dos direitos humanos."

\footnotetext{
${ }^{57}$ TRINDADE, Antonio Augusto Cançado. op. cit. p., 111. "O ordenamento internacional tradicional, marcado pelo predomínio das soberanias estatais e exclusão dos indivíduos, não foi capaz de evitar a intensificação da produção e uso de armamentos de destruição em massa, e tampouco as violações maciças dos direitos humanos perpetradas em todas as regiões do mundo, e as sucessivas atrocidades de nosso século, inclusive as contemporâneas, - como o holocausto, o gulag, seguidos de novos atos de genocídio, (...) Tais atrocidades têm despertado a consciência jurídica universal para a necessidade de reconceitualizar as próprias bases do ordenamento internacional".

${ }^{58}$ RAMOS, Elival da Silva. Os tratados sobre direitos humanos no Direito Constitucional Brasileiro, p. 167.

${ }^{59}$ LAFER, Celso. A Internacionalização dos Direitos Humanos: Constituição, racismo e relações internacionais, p.16.
} 
O Supremo Tribunal Federal, quando do julgamento do Recurso Extraordinário 466.343/SP que analisava controvérsia jurídica acerca da subsistência, no direito positivo brasileiro, da prisão civil por depósito infiel, considerando o que dispõe o artigo $7^{\circ}, \S 7^{\circ}$, da Convenção Americana de Direitos Humanos, reviu o posicionamento anteriormente adotado pela Corte, tendo, por maioria de votos, decidido que os tratados internacionais de direitos humanos que não forem aprovados pelo rito especial do art. $5^{\circ}, \S 3^{\circ}$, da Carta Cidadã, têm natureza supralegal, ou seja, abaixo da Constituição, mas acima de todas e quaisquer leis.

Nesse julgado restaram vencidos os Ministros Celso de Mello, Cezar Pelluso, Ellen Gracie e Eros Grau, adotando posicionamento de doutrinadores como Celso Lafer e Flávia Piovesan, dentre outros que concediam hierarquia constitucional a todos os tratados de direitos humanos, aprovados, ou não, pelo rito especial, do art. $5^{\circ}, \S 3^{\circ} .^{60}$

Como se percebe, atualmente, as relações entre o direito internacional dos direitos humanos e o direito interno "estão a rumar para um novo horizonte em tempos pósmodernos". Esse horizonte é o da primazia dos direitos humanos, independentemente do sistema jurídico do qual provêm. Essa primazia consolida-se como um princípio do direito internacional público pós-moderno, já nominado de princípio internacional pro homine" 61 .

\footnotetext{
${ }^{60}$ Vale, neste ponto, transcrever trecho do voto do Ministro CELSO DE MELlO, do STF, no RE 80.004: “圣ós $\underline{\text { muita }} \underline{\text { reflexão }}$ sobre esse tema, e não obstante anteriores julgamentos desta Corte de que participei como

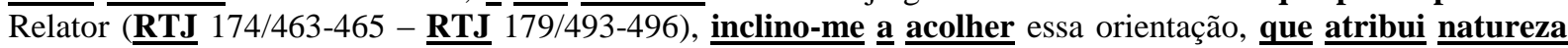
constitucional às convenções internacionais de direitos humanos, (...) Com efeito, esta Suprema Corte, ao interpretar o texto constitucional, atribuiu, em determinado momento (décadas de 1940 e de 1950), superioridade às convenções internacionais em face da legislação interna do Brasil (...), muito embora, em sensível mudança de sua jurisprudência, viesse a reconhecer, em momento posterior (a partir da década de 1970), relação de paridade normativa entre as espécies derivadas dessas mesmas fontes jurídicas (...). Como precedentemente salientei neste voto, e após detida reflexão em torno dos fundamentos e critérios que me orientaram em julgamentos anteriores (...), evoluo, Senhora Presidente, no sentido de atribuir, aos tratados internacionais em matéria de direitos humanos, superioridade jurídica em face da generalidade das leis internas brasileiras, reconhecendo, a referidas convenções internacionais, nos termos que venho de expor, qualificação constitucional. (...) Em suma: o entendimento segundo o qual existe relação de paridade normativa entre convenções internacionais $\underline{\mathbf{e}}$ leis internas brasileiras há de ser considerado, unicamente, quanto aos tratados internacionais cujo conteúdo seja materialmente estranho ao tema dos direitos humanos. (...) $\underline{\mathbf{E}}$ preciso ressaltar, no entanto, como precedentemente já enfatizado, as convencões internacionais de direitos humanos celebradas antes do advento da EC $\mathrm{n}^{\circ} 45 / 2004$, pois, quanto a elas, incide o $\$ \mathbf{2}^{\mathbf{0}}$ do art. $5^{\circ}$, da Constituição, que lhes confere natureza

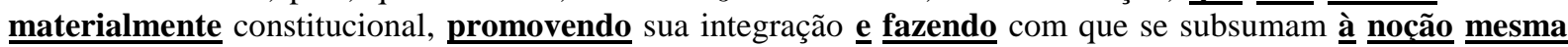
de bloco de constitucionalidade".

${ }^{61}$ BILDER, R. B. Na overview of internacional human rights Law, p. 3/5.

${ }^{61}$ LAFER, Celso. Declaração Universal dos Direitos Humanos (1948), p. 297.

${ }^{61}$ PIOVESAN, Flavia. Hierarquia dos tratados internacionais de proteção dos direitos humanos: Jurisprudência do $S T F$, p. 126.

${ }^{61}$ LAFER, Celso, op. cit., p. 320.
} 
A partir da Constituição, de 1988, testemunha-se o processo de internacionalização do Direito Constitucional somado ao de constitucionalização do Direito Internacional $^{62}$.

Cabe aqui ressalvar que o direito internacional não aceita a justificativa de impossibilidade do direito interno para o não cumprimento de reparação pela violação dos direitos humanos, exigindo, inclusive, a compatibilização das normas internas, de forma a permitir o cumprimento da reparação exigida ${ }^{63}$. Tal posicionamento vê-se assentado na relevante Opinião Consultiva n. 14, de 2004, da Corte Interamericana de Direitos Humanos ${ }^{64}$. Conforme preleciona Carvalho Ramos:

"O debate sobre o estatuto interno dos tratados de direitos humanos trouxe à tona várias ilações sobre a controvérsia entre os monistas e dualistas na história do Direito Internacional. [...] Apesar de ser um tema importante na aplicação interna dos tratados, vimos acima que não importa qual é a visão brasileira sobre o estatuto normativo interno de um tratado internacional de direitos humanos. Reiteradamente os órgãos judiciais e quase-judiciais internacionais impõem o que denomino um 'unilateralismo radical' que se sobrepõe à discussion d'école entre monistas e dualistas: os tratados de direitos humanos deve ser cumpridos". 65

\footnotetext{
${ }^{61}$ MAZZUOLI, Valério de Oliveira. Tratados Internacionais de Direitos Humanos e Direito Interno, p. 227.

${ }^{62}$ PIOVESAN, Flavia. Hierarquia dos ... op. cit., p. 145.

${ }^{63}$ CARVALHO RAMOS, André de, Responsabilidade Internacional por violações de direitos humanos. Seus elementos, a reparação devida e sanções possíveis. Teoria e prática do Direito Internacional, p. 263.

${ }^{64}$ Sítio da internet:http://www.corteidh.or.cr/opiniones.cfm. "1. Que la expedición de una ley manifiestamente contraria a las obligaciones asumidas por un Estado al ratificar o adherir a la Convención, constituye una violación de ésta y, en el caso de que esa violación afecte derechos y libertades protegidos respecto de individuos determinados, genera la responsabilidad internacional de tal Estado. 2 Que el cumplimiento por parte de agentes o funcionarios del Estado de una ley manifiestamente violatoria de la Convención, genera responsabilidad internacional para tal Estado. En caso de que el acto de cumplimiento constituya per se un crimen internacional, genera también la responsabilidad internacional de los agentes o funcionarios que ejecutaron el acto".

Observe-se que no sistema europeu de proteção de direitos humanos existe a possibilidade de o Estado alegar que não consegue cumprir o comando da sentença da Corte, requerendo que se estipule uma satisfação equitativa. O sistema europeu de proteção dos direitos humanos possui com válvula de escape a margem de apreciação, criticada por muito pelo relativismo das decisões.
}

${ }^{65}$ CARVALHO RAMOS, André de, op. cit., p. 823. 
Registre-se, ainda, que a hierarquia normativa dos tratados de direitos humanos deve estar associada à interpretação internacionalista, sem a qual se torna estéril. Ademais, há necessidade de se fazer uma releitura do princípio da primazia da norma mais favorável, já que essa não resolve conflitos, em especial, nos hard cases, entre colisão de direitos da mesma magnitude ${ }^{66}$.

É preciso compreender que, em especial nos Estados Democráticos de Direito, os direitos fundamentais universais não devem ser tidos como reversíveis ${ }^{67}$, sendo inadmissível a ocorrência de indevidas e desproporcionais limitações ao exercício desses direitos. É exatamente nesse contraponto entre, por exemplo, os direitos das vítimas de delitos e os direitos dos investigados que surge a necessidade de uma harmonização, ainda que se inicie de forma tímida, das regras de direito existentes nos diversos sistemas jurídicos, tomando como baliza os direitos humanos, universalmente já consagrados.

Afinal, não se deseja que o progresso da tecnologia e da economia moderna, com a maior integração e circulação de pessoas, bens, capitais e mercadorias, constitua um retrocesso em termos de garantias fundamentais.

Destarte, a globalização surge não só dessa nova forma de produção capitalista, mas também da universalização dos padrões culturais e da necessidade de comum equacionamento de problemas que afetam a todos, tais como meio ambiente, respeito aos direitos humanos, multiplicação de conflitos regionais, dentre outros. ${ }^{68}$

De acordo com Machado ${ }^{69}$ :

\footnotetext{
${ }^{66}$ Id. , p 822

${ }^{67}$ QUEIROZ, Cristina. O princípio da não reversibilidade dos direitos fundamentais sociais. Princípios dogmáticos e prática jurisprudencial, p. 121. “15. Ambos os conceitos de 'conteúdo mínimo' e de 'conteúdo essencial' não são expressões sinónimas ou equivalentes. O princípio da 'efectividade' ou 'efectividade optima' dos direitos fundamentais, incluindo os direitos sociais, a isso se oporia. Nestas hipóteses, não se poderá falar em ‘margem de acção' do legislador, na medida em que este não se encontra autorizado a uma delimitação/restrição dos direitos fundamentais, o que só ocorrerá na hipótese dos direitos fundamentais acompanhados de 'reserva de lei simples' ou de 'reserva de lei qualificada'. Em suma, a 'posição mínima definitiva' no quadro da 'teoria dos princípios' resulta garantida pelo recurso a 'regras jurídicas', não constituindo assim um direito delimitável ou restringível".

${ }^{68}$ VIERIA, Litz. Cidadania e Globalização, p. 73

${ }^{69}$ MACHADO, Maria Costa Neves. Direito à Diferença Cultural. A igualdade e a diversidade cultural dos seres humanos. O direito à diferença cultural na atualidade, p. 195.
} 
"Os direitos humanos devem ser encarados como resultado de processos históricos nos quais diversas tradições culturais exercem influências mútuas umas em relação às outras, até por meio da oposição de manifestações culturais. Os direitos humanos não são apenas resultado da cultura ocidental (ou de qualquer outra cultura), mas desse processo dinâmico de relação entre as diversas tradições culturais. E na medida em que são afirmados em determinado contexto histórico, são reinventados e construídos a partir de condições históricas e culturais diversas."

Assim sendo, pode-se dizer que os direitos humanos constituem padrão normativo universal capaz de viabilizar a cooperação jurídica internacional, com respeito ao justo processo $^{70}$. O paradigma do respeito aos direitos humanos deve ser levado em conta, quer na elaboração legislativa (inclusive tratados bilaterais, multilaterais), quer na aplicação do direito ao caso concreto.

Conforme assevera $\mathrm{Kriele}^{71}$ :

"Os direitos humanos estabelecem condições e limites àqueles que têm competência de criar e modificar o direito e negam o poder de violar o direito. Certamente todos os direitos não podem fazer nada contra o poder fático, a potesta desnuda, como tampouco nada pode fazer a moral em face do cinismo. Os direitos somente têm efeito diante de outros direitos, os direitos humanos, somente em face de um poder jurídico, isto é, em face de competências cuja origem jurídica e cujo status jurídico seja respeitado pelo titular da competência."

\footnotetext{
${ }^{70}$ CANOTILHO, José Joaquim Gomes. Direito Constitucional e Teoria da Constituição, p. 18. "Os direitos humanos articulados com o relevante papel das organizações internacionais fornecem um enquadramento razoável para o constitucionalismo global. O constitucionalismo global compreende não apenas o clássico paradigma das relações horizontais entre Estados, mas no novo paradigma centrado: nas relações Estado/povo, na emergência de um Direito Internacional dos Direitos Humanos e na tendencial elevação da dignidade humana a pressuposto indeclinável de todos os constitucionalismos. Por isso, o Poder Constituinte dos Estados e, consequentemente, das respectivas Constituições nacionais está hoje cada vez mais vinculado à princípio e regras de direito internacional".
}

${ }^{71}$ KRIELI, Martin. Introducción a la teoria del Estado, p. 150. 


\subsection{Criminalidade organizada e cooperação jurídica internacional em matéria penal}

Conforme já se teve oportunidade de assentar, vive-se atualmente em um mundo de criminalidade organizada ${ }^{72}$, em vista do qual há um crescente anseio da sociedade em reprimir, de uma forma mais eficaz e rápida, a prática de crimes econômicos ou não, praticados pela criminalidade organizada que transcendem barreiras nacionais ${ }^{73}$.

Não se há de negar que a sociedade globalizada enfrenta um novo paradigma do direito penal. Para Santos e Rocha ${ }^{74}$ :

"O paradigma do direito penal da globalização é o delito econômico organizado, tanto na modalidade empresarial convencional como nas modalidades da chamada macrocrimonalidade: terrorismo, narcotráfico, ou criminalidade organizada. (tráfico de armas, mulheres e crianças. A delinquiência da globalização é delinqüência econômica, à qual se tende a assimilar menos garantias pela menor gravidade das sanções, ou é criminalidade pertencente ao âmbito da classicamente denominada legislação 'excepcional', à qual se tende assinalar menos garantias pelo enorme potencial de perigo que contém. Ocorre aqui, portanto, algo similar ao sumariamente patenteado com relação às regras dogmáticas de imputação. “

\footnotetext{
${ }^{72}$ FERNANDES, Antonio Scarance. "O equilíbrio na repressão ao crime organizado”. In. Crime Organizado aspectos processuais. Cord. FERNANDES, Antonio Scarance e outros. São Paulo: Revista dos Tribunais, 2009, p. 13. "Por outro lado, a organização criminosa expandiu-se e, neste alargamento, diversificou e flexibilizou as suas atividades, adaptando-se ao mercado e ao desenvolvimento tecnológico, e isso levou a que os estudiosos separassem as organizações em dois grandes tipos: o territorial, tradicional, mafioso, e o empresarial. O primeiro atuaria em áreas determinadas, cobraria pedágio de casas comerciais, utilizaria largamente a violência; o segundo agiria junto a grandes corporações realizaria sofisticados processos de lavagem de dinheiro, operaria no mercado financeiro. Acena-se, ainda, com a tendência existente de os dois grupos atuarem juntos, fundirem-se ou, apesar de se manterem autônomos, prestarem mútua colaboração. [...]. Por isso tudo, ante a multifária atuação das organizações criminosas e a dificuldade em delimitar o crime por elas praticado, alguns, como Francis Rafael Beck, preferem arrolar as suas características, renunciando ao propósito de defini-las legalmente ou de tipificar o crime organizado".

${ }^{73} I d$., p. 13. "Por fim é preciso distinguir crime organizado de terrorismo. A discriminação é feita, essencialmente, com base na diversidade de seus fins, embora os seus praticantes operem de forma semelhante: enquanto uma organização criminosa objetiva lucro, um grupo terrorista quer produzir medo, insegurança, subverter a ordem, sendo motivo por razões ideológicas, políticas e religiosas".
}

${ }^{74}$ SÁNCHEZ, Jesús-María Silva, A expansão do direito penal. Aspectos da política criminal nas sociedades pósindustriais. Série as Ciências Criminais no Século XXI, p. 93/4 
Por sua vez, Rodrigues e Mota $^{75}$ asseveram que "a Globalização é hoje o novo paradigma da política criminal: frente à internacionalização do crime, urge responder com a internacionalização da política ao combate ao crime".

Com efeito, o contexto político vivenciado no período pós - Guerra Fria e em 11 de setembro de 2011 leva, sem sombra de dúvida, à criação de políticas criminais que priorizam a segurança e a legislações que, ao tentarem reprimir a criminalidade em massa, como o terrorismo, adotam medidas extremamente repressivas, na maioria das vezes acabando por desrespeitar direitos e garantias individuais e adquirindo um senão antigarantista.

Conforme assentou Belli ${ }^{76}$ :

“A prioridade conferida à segurança e ao combate antiterrorista jogou os direitos humanos numa 'espiral descendente'. A busca de mais segurança passou a ser vista como incompatível com a promoção dos direitos humanos. Nos EUA, a nova legislação conhecida como 'us Patrioct Act' concedeu poderes inéditos ao governo para violar a privacidade e as liberdades dos cidadãos. A primeira consequência prática da nova legislação foi a detenção de suspeitos com base em alegações vagas, sobretudo os que se encaixam no estereótipo do terrorista (homens árabes muçulmanos). Os EUA e seus aliados, em especial Reino Unido, não demoraram a suplementar a legislação antiterrorista interna com a ação decidida na esfera internacional, com pouca ou nenhuma consideração pelos direitos humanos. $\mathrm{O}$ clima de pânico e medo difuso serviu para justificar medidas tais como a detenção de suspeitos por tempo indeterminado sem acusação formal e sem direito à defesa e julgamento, o virtual 'sequestro' de supostos terroristas em terceiros estados e sua transferência para o exterior sem formalidades da extradição, a criação de zonas de não direito, como a

\footnotetext{
${ }^{75}$ RODRIGUES, Anabela Miranda e MotA, José Luis da, Para uma política criminal européia. Quadro e instrumentos jurídicos da cooperação judiciária em matéria penal no espaço da União Europeia, p. 15

${ }^{76}$ BELLI, Benoni, A politização dos direitos humanos. O Conselho de Direitos Humanos das Nações Unidas e as Resoluções sobre Países, p. 116/8.
} 
prisão da base militar de Guantánamo, e a instauração da tortura como método de investigação e de punição corriqueiro, sobretudo em Guantánamo, no Iraque e no Afeganistão. [...] Nesse contexto global, os direitos humanos são desde logo descartados - ou 'flexibilizados' em nome da prioridade de lutar contra o mal que ameaça a civilização. Perde-se de vista o papel desempenhado pelos direitos humanos como garantia contra o colapso moral da humanidade."

A nova realidade mundial possui importantes reflexos no âmbito do processo penal, especialmente no que se refere a questões relacionadas ao combate à criminalidade e ao direito à prova no mundo jurídico.

Além de existir uma tendência mundial pelo estímulo à repressão, há, sem dúvida, aumento da convivência de inúmeros sistemas jurídicos diversos que, diante da necessidade de coexistência, precisam se adaptar à nova realidade mundial.

Afinal, atualmente vive-se uma inegável intensificação do fenômeno da cooperação jurídica internacional, na qual os países procuram estabelecer regras e procedimentos que auxiliem a apuração dos ilícitos de forma mais célere, almejando a eficácia da solução dos litígios e das questões processuais.

Esse fenômeno ganha, com o passar do tempo, maiores contornos e intensidade no direito brasileiro e no mundial, havendo necessidade de regulamentação da cooperação jurídica, propiciando, assim, maior segurança e confiança entre as nações nesse aspecto ${ }^{77}$.

Nesse sentido, pode-se dizer que o crescimento do volume de demandas, envolvendo interesses transnacionais, acarretou o incremento das ações de caráter legislativo, jurisprudencial e doutrinário dos mecanismos de Cooperação Jurídica Internacional ${ }^{78}$.

A grande dificuldade que surge para os aplicadores do direito diz respeito a como tornar tal cooperação possível, sem violar os direitos e garantias do indivíduo que tão duramente foram conquistados ao longo dos anos. É preciso preocupar-se com a tendência

\footnotetext{
${ }^{77}$ Coord. ARAUJO, Nadia de, Cooperação Jurídica Internacional do Superior Tribunal de Justiça. Comentários à Resolução $n^{\circ}$ 9/2005, p. 2 "o crescente volume das demandas envolvendo interesses transnacionais acarretou o incremento de ações de caráter legislativo, jurisprudencial e doutrinário dos mecanismos de Cooperação Jurídica Internacional".
}

${ }^{78}$ ARAÚJO, Nadia, id., p.3 
antigarantista, de modo a impedir que a balança da Justiça penda para o lado repressivo, sem se preocupar com os direitos e garantias individuais, de forma a desequilibrar o sistema.

Conforme preleciona Scarance Fernandes ${ }^{79}$ :

"Entre as tendências contemporâneas do processo penal, uma vem se manifestando de forma intensa, a que busca o equilíbrio entre a exigência de assegurar ao investigado, ao acusado e ao condenado a aplicação das garantias fundamentais do devido processo legal e a necessidade de maior eficiência do sistema persecutório para a segurança social. Com isso se almeja evitar os extremos do hipergarantismo ou de movimentos como o do Direito Penal do Inimigo ou da Lei e da Ordem. Contudo, ante a impossibilidade de se definir com clareza o que seria esse justo equilíbrio e a imensa dificuldade em traduzi-lo nos textos de lei ou na aplicação concreta do direito, essa tendência representa na realidade somente uma meta, uma diretriz, que deve nortear o processo penal, fazendo com ele, no movimento pendular da história, não se distancie do ponto médio entre a proteção à liberdade e a segurança social."

Se, por um lado, a questão da cooperação jurídica em matéria penal se tornou e se torna cada vez mais uma necessidade, na nova sociedade globalizada (que constantemente exige uma repressão à criminalidade mais rápida e eficaz), sua implementação e aplicação deve se dar de forma cuidadosa, lembrando-se sempre da preservação do jus libertatis.

Nesse contexto, pode-se dizer que o direito à produção de provas serve como instrumento ao acusado em ação penal, como garantia ao contraditório pleno e ao exercício efetivo da ampla defesa.

Ademais, imperioso se faz demonstrar que devem existir limites pré-estabelecidos nos procedimentos a serem adotados na cooperação jurídica internacional em matéria penal,

\footnotetext{
${ }^{79}$ FERNANDES, Antonio Scarance. O equilíbrio entre a eficiência e o garantismo e o crime organizado, p. 231.
} 
possibilitando a obtenção de uma maior agilidade e efetividade no combate à criminalidade mundial, sem, entretanto, qualquer violação aos direitos e garantias individuais.

Sintetizando, é imprescindível que exista uma parametrização da legislação quanto à cooperação jurídica internacional em matéria penal, com elaboração de regras básicas que norteiem o procedimento das diversas formas de cooperação jurídica existentes. Mas não é só, é indispensável que, ao elaborar tratados internacionais de cooperação jurídica, o Estado leve em conta não apenas a persecução do crime, mas também o exercício do direito de defesa, prevendo, nos próprios tratados, a almejada paridade de armas entre acusação e defesa.

Afinal, como assevera Madruga ${ }^{80}$ :

"Não serão outras as gerações que a realidade chamará para construir a nova relação jurisdicional internacional. $\mathrm{O}$ desafio se põe agora e deve ser enfrentado com urgência. Não há alternativa. A produção de normas, a solução de conflitos e a aplicação da lei permanecem ainda razoavelmente compartimentadas em espaços jurídicos (Estados), mas não a vida social. O direito é estatal mas a sociedade é global. Ou aprendemos a promover uma cooperação jurídica internacional célere e eficiente ou continuaremos a testemunhar a impotência do Estado diante dessa nova sociedade."

Destarte, é indispensável a delimitação de diretrizes básicas indispensáveis aos procedimentos adotados na cooperação internacional destinados à produção de provas, de modo a garantir que consequências probatórias negativas aos acusados no processo penal só sejam admitidas mediante o respeito à aplicação dos direitos e garantias individuais de acusados e/ou investigados em persecução penal.

Assim sendo, é preciso privilegiar o status libertatis e ter sempre em mente o direito penal garantista, de modo a impedir que a exigência de combate à criminalidade leve a uma simplificação demasiada dos procedimentos criminais adotados que podem ter como

\footnotetext{
${ }^{80}$ MADRUGA, Antenor. O Brasil e a jurisprudência do STF na Idade Média da Cooperação Jurídica Internacional. In sítio da internet: www.rogatoria.com.br.
} 
efeito o desprezo dos direitos humanos e constitucionais, tais como, mas não exclusivamente, do estado de inocência, do contraditório e da ampla defesa.

No momento atual em que, pelo menos no Brasil, a cooperação ainda se encontra embrionária, torna-se necessário o estudo da admissibilidade jurídica, no processo penal brasileiro, de atos instrutórios e cautelares produzidos mediante cooperação jurídica internacional em matéria penal, no sentido de sua parametrização.

É preciso compreender de vez que o processo penal, ao lidar com direitos eminentemente públicos (jus puniendi e jus libertatis) não pode buscar a verdade dos fatos ou o combate à criminalidade a qualquer custo, devendo-se, sobretudo, tomar extremo cuidado com a simplificação dos procedimentos, para que seja garantida a preservação dos direitos fundamentais e humanos, consagrados nacional e internacionalmente.

Há necessidade de se encontrar um equilíbrio entre os avanços e anseios da sociedade no combate à criminalidade e o respeito aos direitos fundamentais, em especial, aqueles ligados à produção de provas.

Não se pode permitir que o anseio pela celeridade processual e questões relativas à efetividade da cooperação jurídica internacional tenham como "efeito colateral" a indesejável violação dos direitos consagrados universalmente.

Afinal, não se deve subestimar o perigo da relativização dos direitos fundamentais em prol da preservação da paz pública, ou como resposta à crescente criminalidade organizada e globalizada, sob pena de se fragilizar a própria ordem democrática fundamental ${ }^{81}$.

É, sobretudo sob o prisma da existência do princípio publicístico e do respeito aos direitos humanos que serão analisadas as questões afetas à cooperação internacional em matéria penal, para obtenção de prova, realçando-se a necessidade de se conceder paridade de armas para a defesa na cooperação internacional.

\footnotetext{
${ }^{81}$ KLOEPFER, Michael. Os direitos fundamentais da lei fundamental: sucessos, fraquezas, tarefas para o futuro, p. 255. "O desenvolvimento da lei de segurança interna nos Estados Unidos após o 11 de Setembro pode servir como exemplo de advertência, no sentido de, em função da justificativa da preocupação com a segurança dos cidadãos, não relativizar e mesmo danificar a ordem democrática fundamenta”.
} 
Emerge indiscutível que, conforme preleciona Grinover" "numa perspectiva de direito público, a defesa, correlata e justaposta à ação, permeiam todas as situações jurídicas processuais que surgem, passo a passo, ao longo do procedimento e é - mais do que direito uma garantia do acusado, de um lado, e garantia do justo processo do outro".

${ }^{82}$ GRINOVER, Ada Pellegrini. O processo constitucional em marcha, p. 14. 


\section{COOPERAÇÃO JURÍDICA INTERNACIONAL: CONSIDERAÇÕES GERAIS}

Neste capítulo, aborda-se a cooperação jurídica internacional em matéria penal, abrangendo seu conceito, os instrumentos, as dificuldades de sua implementação e reflexos no processo penal brasileiro.

Como já se assentou anteriormente, a necessidade de cooperação jurídica em matéria penal vem crescendo, de forma acelerada, nos últimos anos, impulsionada pelo crescente anseio de combate à criminalidade, em um mundo de interrelações globais.

Rotineiramente tem-se visto a multiplicação da elaboração de tratados internacionais, bilaterais e multilaterais, em matéria de cooperação jurídica penal, que visam estabelecer regras básicas sobre a forma como os Estados podem se auxiliar mutuamente com maior eficácia.

Não obstante os Estados-Nações não possam ser compelidos a cooperar uns com os outros, a elaboração dos tratados impõe, em certa medida, a obrigatoriedade da cooperação, desde que, respeitadas, evidentemente, questões afetas à soberania nacional, à ordem pública e à segurança nacional.

Hodiernamente ouve-se falar do auxílio entre os Estados para o combate à criminalidade organizada, bem como aos crimes de lavagem de dinheiro, corrupção, tráfico ilícito de entorpecentes, dentre outros, que transpassam as fronteiras.

Nessa medida, a cooperação jurídica internacional em matéria penal foi se desenvolvendo para responder aos tradicionais desafios da transnacionalização do crime, por meio da criação de novos instrumentos, mais céleres e eficazes do que os comumente utilizados.

No combate a essa criminalidade, torna-se cada vez mais necessária a obtenção de provas no exterior, de forma a propiciar a busca da verdade atingível. Evidentemente tal busca não pode se dar tão somente pelo enfoque da repressão, deve, sobretudo, estar pautada pelo garantismo $^{83}$, visando propiciar às partes e aos operadores do direito o justo processo.

\footnotetext{
${ }^{83}$ QUITERO, Cristiane Bernades Antunes e PONTES, José Antonio Siqueira. Evolução das garantias constitucionais relativas ao processo penal na América Latina, p. 399. "A aplicação do rol de direitos e garantias
} 
Sob esse prisma, é fundamental assimilar que os direitos humanos e os direitos e garantias fundamentais, consagrados no ordenamento jurídico, constituem o ponto de partida para a cooperação jurídica internacional.

Afinal, Jorge e Silva Neto ${ }^{84}$ asseveram que:

"[...] a "postura do aplicador de direito que não tome por ponto de partida a concretização de garantia fundamental representa, sem dúvida, não apenas um erro crasso para desnudar o conteúdo do preceito constitucional; é um atentado mesmo contra a própria razão ontológica do ente estatal, ente que - diga-se de passagem -, no específico caso do Brasil, tem os seus fundamentos atrelados à consecução da cidadania, da dignidade da pessoa humana e dos valores sociais do trabalho (art. $1^{o}$, II, III, IV), dentre outros elevadíssimos propósitos não à toa guindados ao status de finalidades substanciais do Estado Brasileiro."

É, sobretudo sob o prisma da existência do princípio publicístico e do respeito aos direitos humanos que serão analisadas as questões afetas à cooperação internacional em matéria penal, para obtenção de prova, realçando-se a necessidade de se conceder paridade de armas para a defesa na cooperação internacional.

Conforme assevera Grinover:

"Dois valores relevantes, de certo modo antagônicos, ou pelo menos dialeticamente opostos, têm emergido recentemente em sede de cooperação internacional em matéria penal: de um lado, a necessidade de intensificar a referida cooperação na luta contra o crime; de outro, a consciência cada vez mais profunda de que os direitos fundamentais

relativos ao processo penal na Constituição Federal e sua filiação ao modela garantista em substituição a um sistema de processo penal voltado para busca da verdade material a qualquer custo denotam a adoção de uma nova ordem instrumental penal, em consonância com os mecanismos internacionais ligadas à política de segurança pública até a construção de aparelho processual repressivo de natureza acusatória".

${ }^{84}$ JORGE, Manuel e NETO, SILVA. O princípio da máxima efetividade e a interpretação constitucional, p. 37. (realces nossos). 
devem colocar-se como termo de referência nesta matéria e, consequentemente, como limite à cooperação internacional em matéria penal" 85 .

\subsection{Noções: terminologia adotada, conceito e normatização}

Não há uniformidade terminológica para designar a cooperação jurídica processual e pré-processual entre os diversos Estados. Como restou bem assentado por Abade $^{86}$ :

“ [...] assim, encontramos, em português as expressões 'cooperação jurídica internacional', 'cooperação judiciária internacional', cooperação judicial internacional', assistência mútua internacional e 'cooperação jurisdicional internacional'. Conquanto não haja unanimidade nos países europeus, é possível identificar as expressões dominantes. Assim, na França e Bélgica e em partes da Suíça, usa-se mais comumente 'entraidejudiciare'. Na Espanha os termos mais utilizados são 'cooperation judicial internacional' e 'assitencia judicial'.,

Em que pese a multiplicidade de expressões, opta-se pelo termo "Cooperação Jurídica Internacional”, em especial, por abranger a cooperação, jurisdicional e/ou administrativa, dentre os diversos Estados soberanos ${ }^{87}$.

\footnotetext{
${ }^{85}$ GRINOVER, Ada Pellegrini. Processo Penal Transnacional: linhas evolutivas e garantias processuais, p. 42.

${ }^{86}$ ABADE, Denise Neves. Direitos fundamentais na cooperação jurídica internacional. Extradição, Assistência Jurídica, Execução de Sentença Estrangeira e Transferência de Presos, p.29.

${ }^{87}$ SILVA, Ricardo Perlingeiro Mendes da. Cooperação Jurídica Internacional e auxílio direto, p. 797/809. “A preferência pela expressão 'Cooperação Jurídica Internacional' decorre da ideia de que a efetividade da jurisdição, nacional ou estrangeira, pode depender do intercâmbio não apenas entre órgãos judiciais, mas também entre órgãos administrativos, ou ainda, entre órgãos judiciais e administrativos, de Estados distintos".
} 
Bechara $^{88}$ enfatiza que "a qualificação da cooperação como jurídica está muito mais associada aos efeitos que desta possam advir do que propriamente à natureza do objeto da cooperação ou qualidade de quem coopera”.

Sinteticamente, a cooperação jurídica internacional ${ }^{89}$ constitui um instrumento jurídico de colaboração entre Estados Soberanos, que pode se dar pela via administrativa ou judiciária, ou seja, é um conjunto de atividades processuais regulares de diversos níveis, cumpridas por ordens jurisdicionais de diversos Estados soberanos ${ }^{90}$.

Para Araújo ${ }^{91}$, conforme definição dada no Manual de Cooperação Jurídica Internacional e Recuperação de Ativos, a cooperação jurídica internacional pode ser definida como:

“[...] o intercâmbio internacional para o cumprimento extraterritorial de medidas processuais do Poder Judiciário de outro Estado. Tradicionalmente, também seria incluído nesta matéria o problema da competência internacional. Além disso, hoje há novas possibilidades de uma atuação administrativa do Estado nesta matéria, em modalidades de contato direto entre os entes estatais."

Por sua vez, Cervini ${ }^{92}$ define cooperação como sendo:

\footnotetext{
${ }^{88}$ BECHARA, Fábio Ramazzini. Cooperação Jurídica Internacional em matéria penal, p. 43.

${ }^{89}$ Para SOUZA, Carolina Yumi. Cooperação jurídica internacional em matéria penal: considerações práticas, p.300, a cooperação jurídica internacional "pode ser considerada como um intercâmbio entre estados soberanos, destinando-se à segurança e à estabilidade das relações transnacionais. Tem por premissas fundamentais o respeito à soberania dos Estados e a não impunidade dos delitos. Em sentido lato, engloba todos os atos públicos (legislativos, administrativos e judiciais)".

${ }^{90}$ Noção obtida nas aulas de cooperação jurídica internacional, no curso de doutorado na Faculdade de Direito do Largo São Francisco, aulas estas ministradas pelos Prof. André de Carvalho Ramos e Wagner Menezes.

91 ARAÚJO, Nádia de. A importância da Cooperação Jurídica Internacional para a Atuação do Estado Brasileiro no Plano Internacional, p.40.

Note-se que Fábio Bechara critica o conceito formulado por Nádia de Araújo, por entender que este "não considera a cooperação entre autoridades administrativas, que igualmente se qualifica com jurídica". BECHARA, Fábio Ramazzini. op. cit., p. 42.

${ }^{92}$ CERVInI, Raúl, Tavares. Juarez. Princípios da cooperação judicial penal internacional no protocolo do Mercosul. São Paulo: RT, 2000, p.51.
} 
“[...] conjunto de atividades processuais (cuja projeção esgota nas simples formas), regulares (normais), concretas e de diverso nível, cumpridas por órgãos jurisdicionais (competentes) em matéria penal, pertencente a distintos Estados soberanos, que convergem (funcional e necessariamente) em nível internacional, na realização de um mesmo fim, que não é senão o desenvolvimento (preparação e consecução) de um processo (principal) da mesma natureza (penal), dentro de um estrito marco de garantias, conforme o diverso grau e projeção intrínseca do auxílio requerido.

A cooperação jurídica internacional dá-se em diversos ramos do direito, sendo objeto deste trabalho tão somente a análise da cooperação jurídica internacional ativa em matéria penal.

Conforme se depreende do portal da internet do Ministério da Justiça, “é o intercâmbio internacional de documentos para garantir o cumprimento extraterritorial de medidas judiciais, processuais ou investigativas de outro Estado [...] refere-se a toda e qualquer forma de colaboração entre Estados, para a consecução de um objetivo comum, que tenha reflexos jurídicos (utilização no processo penal)" 93.

Miller ${ }^{94}$ acentua que o conceito de:

“[...] cooperação penal internacional abarca todo o ato praticado por um Estado com a finalidade de subsidiar a formação e o desenvolvimento de investigação criminal ou processo penal em outro Estado com a finalidade de subsidiar a formação e o desenvolvimento de investigação criminal ou processo penal em outro Estado: finalidade cooperativa e pertinência processual penal, ainda que preparatória, são, nessa perspectiva, as características definidoras dos atos que se subsumem ao conceito em foco. Embora a cooperação

\footnotetext{
${ }^{93}$ Portal.mj.gov

${ }^{94}$ OLIVEIRA MILLER, Marcello Paranhos de. O auxilio direito em matéria penal: A moldura jurídica de uma nova vertente de cooperação internacional, p. 38.
} 
penal internacional geralmente instrumente a persecução penal, nenhum princípio a ela relativo impede a prática de atos que tendam a instrumentar a reação defensiva da imputação."

Prossegue o autor: "A finalidade da cooperação penal internacional consiste em abrandar o princípio da territorialidade da jurisdição e, em particular, da jurisdição penal" 95 .

A cooperação jurídica internacional em matéria penal é um tema do direito internacional ${ }^{96}$ - partindo da limitação do poder do Estado, diante da indubitável necessidade de convivência pacífica entre Estados nacionais ${ }^{97}$, existentes em uma constelação de Estados assimétricos $^{98}$, que se conjuga com os elevados valores do direito penal e processual penal.

Com o aumento vertiginoso da demanda pela cooperação jurídica internacional, há necessidade de uma maior regulamentação da matéria, propiciando incremento da segurança jurídica, voltando-se os Estados para uma normatização dessas relações de mútua assistência.

Infelizmente, apesar da elevada dimensão que a cooperação jurídica internacional vem ganhando, não há, ainda, uma teoria geral da cooperação jurídica, sendo, portanto, imprescindível estabelecer requisitos básicos a serem observados no processo cooperacional.

Tal tarefa constitui um grande desafio, entretanto, não é objeto deste trabalho, embora a ausência de uma maior sistematização da cooperação jurídica internacional constitua um dos empecilhos da colaboração entre Estados.

A necessidade de garantia dos direitos humanos no processo de cooperação jurídica e a discussão da incidência dos direitos fundamentais são imprescindíveis para a cooperação jurídica internacional em matéria penal, constituindo um avanço. Entretanto, a

\footnotetext{
${ }^{95}$ Id., p. 38.

${ }^{96}$ Não se almeja aqui discutir questões doutrinárias acerca da criação ou não de um novo ramo do direito, designado como Direito da Cooperação Jurídica Internacional.

${ }^{97}$ BOBBIO, Norberto, O Terceiro Ausente. Ensaios e discursos sobre a paz e a guerra, p. 117. Conforme assevera Bobbio, "os movimentos dos direitos do homem e os movimentos pela paz se encontram e avançam lado a lado. Avançado lado a lado, fortalecem-se mutuamente. A paz é condição sinequa non para uma eficaz proteção dos diretos do homem e, ao mesmo tempo, a proteção dos direitos do homem favorece a paz".

${ }^{98}$ MACHADO, Maria Costa Neves, Direito à Diferença Cultural. A igualdade e a diversidade cultural dos seres humanos. $O$ direito à diferença cultural na atualidade. p. 183. "Na atualidade, o debate intercultural entre nações envolvendo os direitos humanos insere-se no contexto de oposição entre a afirmação de valores universais e o reconhecimento das particularidades específicas de cada cultura".
} 
realidade tem mostrado uma "fragilização da proteção dos direitos fundamentais dos indivíduos sujeitos aos pleitos cooperacionais ${ }^{99}$.

Nesse diapasão, em que pese os direitos humanos tenham sido incorporados ao ordenamento jurídico brasileiro, conforme já se teve oportunidade de assentar, é preciso ver que "de nada adianta um Poder Judiciário que não seja capaz de conferir eficácia aos direitos fundamentais se o Poder Judiciário não é capaz de garanti-los, de implementá-los”, conforme palavras de Campilongo ${ }^{100}$.

As sociedades nacionais e a internacionais são caracterizadas pela heterogeneidade, sendo necessária, portanto, uma harmonização normativa, que pressupõe a incorporação de normas internacionais ao direito interno, alicerçada nos direitos humanos e fundamentais universais, para que haja efetividade na cooperação jurídica internacional.

Segundo Colomber há um desejo intelectual de que todos os países democráticos tenham um processo similar, "submetido a iguais princípios que dêem lugar às mesmas ou muito parecidas pautas de atuação prática, é evidente, não necessita fundar-se doutrinariamente já dos dias de hoje"

Diante desse cenário, não há como duvidar de que "as ordens constitucional e internacional se devam conjugar, em bases de harmonia e complementaridade, quando se tratar da tutela dos direitos fundamentais do homem", na visão de Siqueira Castro ${ }^{102}$, que prossegue:

“[...] a globalização do humanismo superou a visão isolada e nacionalizada do destino e das vicissitudes humanos, a ponto de alcançar não apenas as relações entre os Estados e entre Estadoindivíduo, mas também as relações privadas tradicionalmente regidas pelo Direito Internacional Privado (DPI), que hoje já experimentam o

\footnotetext{
${ }^{99}$ ABADE, Denise Neves. Direitos fundamentais na cooperação jurídica internacional. Extradição, Assistência Jurídica, Execução de Sentença Estrangeira e Transferência de Presos, p. 168.

${ }^{100}$ CAMPILONGO, Celso Fernandes. O Direito Na Sociedade Complexa. Com apresentação e ensaio de Raffele De Giorgio, p. 101.

${ }^{101}$ COLOMBER, Juan-Luis Gómez. A investigação criminal Problemas atuais e perspectivas e Unificação Internacional, p.199/200.

${ }^{102}$ CASTRO, Carlos Alberto Siqueira. A constituição aberta e os direitos fundamentais. Ensaios sobre o constitucionalismo pós-moderno e comunitário, p. 141/2.
} 
influxo da publicização e da ideológica dos direitos humanos. A ideia da pluralidade extrema de ordens jurídicas, a sua vez calcada na premissa da pluralidade de Estados não pode mais ser vista como impeditiva da harmonização em escala planetária entre os vários sistemas normativos de proteção dos direitos dos homens."

O ordenamento jurídico brasileiro não possui, de forma estruturada e sistêmica, lei que contemple a cooperação jurídica com o exterior, diversamente do que ocorre em países como Alemanha (cível e penal), África do Sul, Argentina, Reino Unido e a Suíça ${ }^{103}$.

A legislação acerca da cooperação jurídica internacional em matéria penal no Brasil encontra-se muito fragmentada ${ }^{104}$, dificultando a tarefa do operador do direito, sendo imprescindível uma maior e mais coesa regulamentação.

O pluralismo jurídico não oferece respostas satisfatórias à questão da eficácia da cooperação jurídica internacional e do respeito aos direitos humanos fundamentais, sendo imperioso que exista uma harmonização ${ }^{105}$ das legislações entre os diversos Estados. Afinal, é evidente que os Estados só conseguirão cooperar de forma eficaz ${ }^{106}$, se possuírem uma legislação processual adequada e atenta aos direitos fundamentais do homem.

Conforme estabelece o artigo $2^{\mathbf{o}}$ da Carta das Organizações dos Estados Americanos, o propósito essencial desses Estados é "procurar as soluções dos problemas políticos, jurídicos e econômicos que surgirem entre os Estados-Membros”. Para atender a

${ }^{103}$ KLEEBANK, Susan. Cooperação judiciária por via diplomática. Avaliação e propostas de atualização do quadro normativo. Coleção Curso de Altos Estudos do Instituto Rio Branco, p. 18.

${ }^{104}$ Art. $4^{\circ}$, IX, da CF/88; artigos 780 a 790 do Código de Processo Penal; art. 1º da Lei 9613/98.

${ }^{105}$ Além da harmonização, a unificação e a uniformização, representam diferentes estratégias de internacionalização do direito. Conforme assevera ROCHA MACHADO, Maíra. Internacionalização do direito penal. A gestão de problemas internacionais por meio do crime e da pena, p. 211. "No tocante à unificação, isto é, à substituição de direitos formalmente distintos por um corpo único de disposições, o Tribunal Penal Internacional permanente pode constituir uma ilustração. Rodos os países que ratificaram o Estatuto de Roma têm unificados os seus sistemas jurídicos no tocante ao modo de definir e tratar os crimes [...] No tocante à uniformização e à harmonização o capitulo II já adverte sobre a dificuldade empírica de diferenciação entre esses dois processos em matéria penal, tendo em vista que a incorporação a um ordenamento jurídico interno é condição indispensável à sua aplicabilidade. Distinguir entre esses dois processos depende, portanto, de um esforço casuístico voltado a determinar se a regra interna resultante é idêntica (no caso da uniformização) ou equivalente (no caso da harmonização) à regra internacional que desencadeia o processo"

${ }^{106}$ BOBBIO, Norberto. O Terceiro Ausente. Ensaios e discursos sobre a paz e a guerra, p. 165. "É claro que, no momento em que entra em cena o direito, o problema não é mais aquele da validade da regra, qualquer que seja ela, mas sim aquele da sua eficácia, no nosso caso específico, não mais o problema do fundamento racional do princípio pacta sunt servanda, mas da sua efetiva (ao máximo possível) aplicação”. 
esse propósito, há necessidade de harmonização dos princípios e regras ${ }^{107}$ básicas entre os Estados.

Uma tentativa de sistematização da cooperação jurídica internacional é a criação, no âmbito regional, de Códigos Modelos. Nesse sentido, “o projeto de Código Modelo de Cooperação interjurisdicional para a Ibero-América é bastante arrojado, com uma sistematização absolutamente inédita, não obstante os seus princípios e regras tenham sido construídos a partir da experiência recente dos países ibero-americanos e de suas normas em vigor (de fonte interna e externa)" 108 .

Evidentemente que não se pode dissociar a cooperação jurídica internacional em matéria penal do valor da solidariedade ${ }^{109}$ entre os Estados, afinal "o turbilhão de inter-

107 Ver ALEXY, Robert. Teoria dos Direitos Fundamentais, p. 91/3“A diferença entre regras e princípios mostra-se com maior clareza nos casos de colisões entre princípios e de conflitos entre regras. Comum às colisões entre princípios e aos conflitos entre regras é o fato de que duas normas, se isoladamente aplicadas, levariam a resultados inconciliáveis entre si, a dois juízos concretos de dever-ser jurídico contraditórios. E elas se distinguem pela forma de solução do conflito. (...). Um conflito entre regras somente pode ser solucionado se se introduzir, em uma das regras, uma cláusula de exceção que elimine o conflito, ou se pelo menos uma das regras for declarada inválida. (...). As colisões entre princípios devem ser solucionadas de forma completamente diversa. Se dois princípios colidem - o que ocorre, por exemplo, quando algo é proibido de acordo com um princípio e, de acordo com o outro, permitido -, um dos princípios terá que ceder. Isso não significa, contudo, nem que o princípio cedente deva ser declarado inválido, nem que nele deverá ser introduzida uma cláusula de exceção. Na verdade, o que ocorre é que um dos princípios tem precedência em face do outro sob determinadas condições. Sob outras condições a questão da precedência pode se resolvida de foram oposta".

${ }^{108}$ Exposição de motivos do Código Modelo Interjuridicional para Ibero-América.

109،Termo de origem jurídica que, na linguagem comum e na filosófica, significa: $1^{\text {o }}$ inter-relação ou interdependência; $2^{\circ}$ assistência reciproca entre os membros de um mesmo grupo (p. ex. S familiar, S. humana, etc). Neste sentido fala-se de solidarismo para indicar a doutrina moral e jurídica fundamentada na S. (Cf. L. BourgEOIS, La solidarité, 1987)”, em ABBAGNANO, NICOLA, Dicionário de Filosofia, p. 918.

Ver também TORRES, Ricardo Lobo, KATAOKA, Eduardo Takemi, GALDINO, Flavio (org.). Dicionário de Princípios Jurídicos, p.1276/7. “A solidariedade está consagrada no Direito Civil como o 'compromisso pelo qual as pessoas se obrigam umas com as outras e cede uma delas a todas'. [...] Pode-se afirmar no final do século XIX e início do século XX a preocupação com o social emerge na consciência dos juristas e inúmeras teorias surgem com fundamento no social e, por conseguinte, também na solidariedade [...]. No DIP, que surge em uma sociedade não estruturada o princípio da solidariedade aparece de forma modo mais raro. É assinalado que a responsabilidade internacional é solidária quando fundamentada em texto convencional. Assim determina a convenção de 1972 sobre a responsabilidade internacional de danos causados por objetos espaciais, quando o lançamento deste é realizado por mais de um Estado. A palavra solidariedade figura pouco nos textos internacionais, por exemplo, no chamado 'Protocolo de Genebra' ou 'Protocolo para Solução Pacífica das Controvérsias Internacionais' (1924), cujo preâmbulo é afirmado: 'Reconhecendo a solidariedade que une os membros da comunidade internacional; Afirmando que a guerra e a agressão constitui uma violação dessa solidariedade e um crime internacional'. Na Carta do OEA, cujo art. 3 versa sobre os 'Princípios' determina: 'A solidariedade dos Estados Americanos e os altos fins que ela visa requerem a organização política dos mesmos com base no exercício efetivo da democracia representativa'. Nenhum internacionalista ousaria afirmar que não há solidariedade na ordem internacional. Ela existe, por exemplo, nas catástrofes naturais, quando os Estados enviam gêneros alimentícios, equipes de socorro etc. A unidade do gênero humano é um dado da antropologia. A solidariedade precisa ser construída e é um ideal que está sempre presente nos internacionalistas. Acreditamos mesmo no seu grande desenvolvimento, uma vez que inúmeros textos internacionais, como a Carta da ONU, estabelecem o dever jurídico da cooperação internacional, que vai gerar, quando já não existe, a solidariedade". 
relacionamentos (sic) faz com que surjam solidariedades transfronteiriças que alimentam o crescimento dos interesses sobre assuntos internos de seus vizinhos. Isso gera um efeito de contágio que ilustra bem sugestivamente a vaporização das fronteiras nacionais e, talvez, o futuro prove que maior sacrifício da autonomia do Estado soberano seja ainda necessário" 110 .

Conforme Bechara ${ }^{111}$ é fundamental a correlação da cooperação jurídica internacional com o valor solidariedade "principalmente para a superação dos problemas que afetam o processo de assistência. Na constituição de 1988, por exemplo, o valor da solidariedade representa um dos objetivos fundamentais do Estado, e a cooperação para o progresso da humanidade, um dos princípios que rege as suas relações internacionais".

\subsection{Vetores da Cooperação Jurídica Internacional: soberania, cooperação interessada e reconhecimento mútuo e confiança.}

Obviamente que não se pode adentrar na análise da cooperação jurídica em matéria penal sem passar pelas tortuosas questões afetas à soberania ${ }^{112}$, que possui relevantes reflexos no direito internacional. A cooperação jurídica é um tema de direito internacional, possuindo fragmentos reelaborados a partir da necessidade de convivência pacífica entre Estados Nacionais.

\footnotetext{
${ }^{110}$ ROCHA, Luiz Alberto G. S. Estado, Democracia e Globalização, p. 161.

${ }^{111}$ BECHARA, Fábio Ramazzini. Cooperação Jurídica Internacional em matéria penal. Eficácia da prova produzida no exterior, p.44.

${ }^{112}$ TORRES, Ricardo Lobo, KATAOKA, Eduardo Takemi, GALDINO, Flavio. Dicionário de Princípios Jurídicos, p. 1259/60. "Etimologicamente, a palavra soberania tem origem no latim superamus. O termo nos oferece a ideia de um grau supremo de hierarquia política, de um poder supremo que não reconhece outro acima. (suprema potestas uperiorem non recognoscens). (...) O conceito de soberania começa a ganhar força na Idade Média. Segundo Celso de Mello, a partir dos últimos trinta anos do século XII é que surgem a palavra 'soberano' e 'soberania'.. [...]. Com o Tratado de Wesefália de 1648, a excessiva fragmentação do poder existente na Idade Média findou e passou a existir, ao menos formalmente, uma igualdade jurídica dos Estados. Fundou-se um sistema internacional semelhante ao existente atualmente em que cada soberano exerce comandos dentro de seu território. Com isso, a expressão par imparem non habet judicium (um igual não possui jurisdição sobre outro igual,) passou a ser largamente empregada. Saindo da realidade europeia, voltamos nossa atenção para o Brasil atual. Aqui, a Constituição de 1988 faz menção expressa à soberania em diversos artigos de alta relevância para a existência do Estado, o que já denota preocupação do constituinte com sua imprescindibilidade para o funcionamento de um Estado Democrático de Direito. Com a leitura dos artigos da Constituição que tratam da soberania, podemos chegar à conclusão de que ela não recebe a conotação de mero compromisso, de mera expressão desprovida de densidade normativa. Configura, na verdade, um princípio de indispensável observância pelo ordenamento jurídico brasileiro. Embora, em uma sociedade dinâmica, a Constituição tenha como pressuposto uma estrutura aberta e um certo teor de indeterminação, essas características não devem permitir que a soberania seja exclusivamente empregada num tom poético, ufanista ”.
} 
Como preleciona Cervini ${ }^{113}$ :

“[...] toda medida de cooperação penal internacional leva implícita, de algum modo, a intromissão de uma ordem jurídica (requerente) dentro de uma outra (requerida), e uma afetação de direitos patrimoniais e pessoais, cuja medida e gravosidade dependerá, em primeiro lugar, da natureza processual da medida de assistência solicitada, e, em segundo lugar, da duração de coercibilidade."

A soberania dos Estados, vista em sentido clássico, fundada no conceito de homogeneidade, constitui um dos grandes problemas enfrentados na implementação da Cooperação Jurídica Internacional, já que ela traz, em seu âmago, a primazia do direito nacional ou repúdio ao que não é nacional, pressupondo o princípio da não intervenção e o domínio reservado do Estado.

Nesse sentido, Nye Junior ${ }^{114}$ assevera que:

“[...] a soberania é um conceito fundamental do sistema wesfaliano e foi reforçado pelo Pacto da Liga das Nações e pela Carta das Nações Unidas. Além disso, situa-se no centro das discussões sobre a legitimidade das intervenções. Embora soberania implique controle absoluto de um território em sentido jurídico, o controle de fato por um governo dentro de suas fronteiras é sempre uma questão de graus.”

O conceito clássico de soberania ${ }^{115}$ não serve mais aos dias atuais, diante das mutações oriundas da globalização ${ }^{116}$ existentes no campo internacional e nacional, que

\footnotetext{
${ }^{113}$ CERVINI, Raúl, e TAVAREZ, Juares. Princípios de Cooperação Judicial Penal Internacional no Protocolo do Mercosul, p. 66/7.

${ }^{114}$ NYE JR., Joseph S. Cooperação e conflito nas relações internacionais. Uma leitura essencial para entende as principais questões da política mundial, p. 203.

${ }^{115}$ ABBAGNANO, Nicola. DicIONÁRIO DE FILOSOFIA, p. 911 "Poder predominante ou supremo do Estado, considerado pela primeira vez como caráter fundamental por Jean Bodin, em Six livres de la répubilque”.
} 
tornam, dentre outras coisas, preeminente a cooperação jurídica internacional, conforme já se teve oportunidade de assentar.

De acordo com Castro ${ }^{117}$ : "De fato, é hoje incontroverso que a visão do Estatismo conservador, que privilegia o primado do direito interno, acabou rendendo- se ao fenômeno da universalização do sistema de proteção dos direitos humanos”.

Conforme acentua Canotilho ${ }^{118}$ : "O Poder Constituinte soberano criador de Constituições está hoje longe de ser um sistema autônomo que gravita em torno da soberania do Estado. A abertura ao Direito Internacional exige a observância de princípios materiais de política e direito internacional tendencialmente informador (sic) do Direito Interno".

Destarte, Polin ${ }^{119}$ considera que:

"[...] com os olhos voltados para o processo de globalização e de regionalização, que constituem fenômenos que se integram e se complementam, muitos vaticinam o fim ou a relativização da soberania e, até mesmo, o desaparecimento do Estado. Nada indica, todavia, que isso irá acontecer num futuro próximo. Embora os Estado possam ter eventualmente a autonomia cerceada e, alguns aspectos, a sua soberania, ao menos no que ela em de essencial, não se vê afetada. $\mathrm{Na}$ realidade, jamais um Estado, por mais poderoso que fosse, logrou subtrair-se integralmente aos condicionamentos de natureza jurídica ou de ordem fática. A ideia de uma soberania sem limites, aliás, nunca existiu, muito menos tem lugar os dias atuais, sobre tudo porque transformações históricas pelas quais os Estados passaram fizeram

\footnotetext{
${ }^{116}$ ROCHA, Luiz Alberto G. Estado, Democracia e Globalização, p. 161. “Apesar das bases da soberania, no sentido de Westphalia, estarem se deteriorando não se pode negar que os Estados são ainda os grandes atores da política internacional que continua centrada em suas ações, mesmo que se possa falar hoje, com bom grau de certeza, que o palco não apresenta mais um monólogo, mas uma companhia de atores composta também por empresas multinacionais, blocos regionais e sociedade civil organizada em Organizações Não Governamentais. Mas, apesar das forças de mutação impostas pela globalização, ainda hoje a sociedade mundial é politicamente composta de Estados Nacionais".

${ }^{117}$ CASTRO, Carlos Roberto Siqueira. A constituição aberta e os direitos fundamentais. Ensaios sobre o constitucionalismo pós-moderno e comunitário, p. 136.

${ }^{118}$ Id., p. 18.

${ }^{119}$ POLIN, Raimond. Le concept de sourerainetéet se consequencesinternationals”, p. 12.
} 
com que acabasse ficando mais flexível do que a noção legada pela tradição."

Apesar de alguns doutrinadores sustentarem que, após o 11 de setembro de 2011, tenha havido um fortalecimento da soberania clássica, não se pode negar que, diante do dinamismo da nova realidade mundial e da intersecção cada vez maior do direito nacional com o internacional (inclusive, com a constitucionalização de direitos fundamentais universais), o conceito de soberania tem que ser revisto, não podendo ser analisado de forma rígida e extremamente formal ${ }^{120}$.

Embora, à primeira vista, possa parecer que a cooperação jurídica no mundo globalizado e a noção de soberania ${ }^{121}$ sejam colidentes, isso não constitui realidade. Afinal, quando um Estado soberano resolve, por inúmeros motivos, cooperar com outro, a própria decisão de cooperar e de executar essa cooperação envolve um ato voluntário de parcialmente sacrificar a autodeterminação nacional interna ou externa. Essa autodeterminação constitui uma representação do exercício da soberania ${ }^{122}$.

\footnotetext{
${ }^{120}$ ROCHA, Luiz Alberto G. Estado, Democracia e Globalização, p. 1259. "O princípio da soberania do Estadonação está em crise e não existe, ainda, uma solução alternativa ao modelo existente. Quando a humanidade parecia estar definitivamente caminhando rumo à crença em órgãos de deliberação transnacionais, os ataques de 11 de setembro de 2011 originou uma abrupta guinada em direção ao fortalecimento da soberania e dos valores nacionalistas, o que foi, inclusive, reforçado com o ataque dos Estados Unidos da América ao Iraque, deflagrado em março de 2003, sem autorização do Conselho de Segurança da ONU. A despeito do pontual fortalecimento acima narrado da soberania, o Estado-nação vem perdendo, de um modo geral, liberdade na condução de sua política (interna e externa), ficando assim, limitado por normas internacionais e, cada vez mais, por pactos regionais. A soberania tem sido atenuada para permitir a aceitação do Estado no contexto internacional e força estatal passa a dividir espaço com outros feixes de poderes, cujos centros de irradiação situam-se até mesmo fora do seu território. A soberania estatal não pressupõe o conceito de algo eterno e universal. Remonta por outro lado, a uma época da civilização ocidental em que os indivíduos foram substituídos pelos Estados no âmbito internacional. O Estado-nação europeu erradicou a pulverização do poder, acabando com a anarquia feudal. No entanto, nada há, ao que tudo indica, que impeça a substituição do Estado em sua feição atual por um outro modelo capaz de viabilizar a paz mundial e de satisfazer os anseios de cada comunidade".

${ }^{121} I d$., p. 1263. "A doutrina divide a soberania em interna e externa com base no âmbito de sua incidência. A primeira diz respeito aos poders do Estado no âmbito interno. Trata-se da competência de um Estado sobre seu território. [...] A soberania externa, por seu turno, diz respeito às relações do Estado no cenário internacional. Ela possui um sentido relacional, referindo-se à relação entre Estados. De acordo com as palavras de Celso Mello, a soberania externa representa 'o direito à independência que se manifesta no: a) direito de convenção; b) direito à igualdade jurídica; c) direito de legação; d) direito ao respeito mútuo" ".
}

${ }^{122}$ LEOWENSTEIN, Karl. Soveringnty and International Co-operation, p 222/244. www.jstor.org.stable/2194372. "If the nationalism by definition refers to the primacy of the national interest, international co-operation may be considered an enlightened nationalism because it is in the interest of one nation to co-operate with others instead of standing aloof or being hostile, jus as it is in the interest of an individual to live on friendly and co-operative terms with the other members of his community. (...) Whenever a state resolve, for specific reasons of its own national interest or, in rarer instances, on altruistic grouds, to co- 
Como preleciona Choukr ${ }^{123}$, "ainda que por sede argumentativa se queira recorrer aos padrões clássicos de soberania, é necessário ser destacado que mesmo a atuação nacional na celebração de tais tratados é manifestação da atividade soberana do Estado".

Nesse diapasão, Araújo conclui ser "preciso conjugar as perspectivas ex parte principis e ex parte populi, para cuidar dos anseios do Estado e do indivíduo no atendimento dessa nova demanda dos dias atuais, em que a soberania dos países se afirma, sobretudo pela atitude positiva de Cooperação Jurídica Internacional" ${ }^{124}$.

Segundo Abade $^{125}$, a produção dos primeiros diplomas normativos sobre cooperação jurídica internacional e a consolidação do costume internacional de reciprocidade (qui pro quod), orientaram-se pelo paradigma do soberanismo ou coexistência desigual. Diante da pluralidade de sistemas jurídicos existentes entre os Estados nacionais, o soberanismo pode redundar em uma cooperação desigual, pautada pela obediência a um conjunto de valores de um dos Estados, caso contrário não se realizará.

Nesse sentido, há necessidade de se encontrar um equilíbrio na cooperação jurídica internacional, sem que se dê prevalência a um sistema em detrimento de outro, superando-se, portanto, restrições indevidas à cooperação, que noções "antiquadas" de soberanismo podem acarretar.

Como é cediço, a partir do final do século XX, visando reprimir a crescente criminalidade transnacional, houve o fenômeno da juridificação das relações entre os Estados nacionais e, por conseguinte, a normatização da cooperação jurídica. Os Estados, autolimitando-se em uma cooperação interessada, passam a negociar e formular, com mais intensidade, tratados internacionais, bilaterais, multilaterais e regionais, nos quais se prevê, inclusive, a diminuição das hipóteses de negativa da cooperação em razão da soberania nacional ou das escolhas locais, mantendo-se a cooperação sob o vetor do "interesse nacional" 126

operate with others, the decision itself and the procedure of executing the decision involve the voluntary act of a partial surrender or sacrifice of internal and/or external national self-determination".

${ }^{123}$ CHOUKR, Fauzi Hassan. A convenção Americana dos Direitos do Humanos e o Direito Interno Brasileiro, p. 12.

${ }^{124}$ ARAUJO, Nadia de. op. cit., p. 17.

${ }^{125}$ ABADE, Denise Neves. Direitos fundamentais na cooperação jurídica internacional. Extradição, Assistência Jurídica, Execução de Sentença Estrangeira e Transferência de Presos, p. 59.

${ }^{126}$ ABADE, Denise Neves. op. cit. ,p.62. 
$\mathrm{Na}$ formulação dessa normatização, os Estados levam em conta os direitos humanos $^{127}$, que tanto limitam quanto inspiram a conquista do multiculturalismo ${ }^{128}$. Há uma crescente pressão mundial para o desenvolvimento de uma cooperação jurídica célere e eficaz $^{129}$, sendo certo que os Estados nacionais passam a confiar uns nos outros, reconhecendo mutuamente as decisões judiciais dos diversos sistemas jurídicos existentes, sem maiores avaliações nacionais de controle dos pedidos ${ }^{130}$. Destarte, o princípio da confiança foi entre os valores jurídicos legalmente protegidos.

Segundo Wald ${ }^{131}$ :

“[...] o respeito à confiança passou a ser considerado, recentemente, como um princípio geral do direito, incidente tanto nas relações privadas como no setor público. Dito de forma mais simples, o assim chamado princípio da confiança demanda previsibilidade da conduta de todos os integrantes do convívio social, inclusive do Estado, das empresas e das pessoas nas suas relações com os demais. Ultrapassada a fase em que dele se tratava apenas incidentalmente, como um mero valor ético subjacente, o princípio da confiança tornou-se objeto de tratados, leis e decisões jurisprudenciais em vários países."

Assim sendo, está implícita, no princípio da confiança, a garantia da previsibilidade e da estabilidade nas relações jurídicas. No campo da cooperação jurídica

\footnotetext{
${ }^{127}$ Ver RAMOS, André de Carvalho, Processo Internacional de Direitos Humanos. Análise dos sistemas de apuração de violações dos direitos humanos e a implementação das decisões no Brasil, p. 22. "A Carta de São Francisco e a Declaração Universal dos Direitos Humanos de 1948 reforçam esse entendimento, consolidando a legitimidade da preocupação internacional com a proteção de direitos humanos, desvinculada da proteção diplomática, na qual defendia-se o indivíduo somente quando do interesse do Estado de sua nacionalidade. A proteção internacional dos direitos humanos busca proteção ao indivíduo sem a menção à nacionalidade ou ao país de sua origem. De fato, a Carta da ONU, em sua artigo 55, prevê o respeito e a necessidade de observância dos direitos fundamentais e ainda a obrigação de concretizar um mínimo padrão sócio-econômico de vida às pessoas. Nesse sentido, dezenas de outras convenções internacionais reforçam também a internacionalização dos direitos humanos".

${ }^{128}$ Ver KYMLICKA, Will, Multiculturalismo Liberal e Direitos Humanos, p. 224.

${ }^{129}$ HÄBERLE, Peter, Estado Constitucional Cooperativo, p. 19. “O Estado Constitucional Cooperativo vive de necessidade de cooperação no plano econômico, social e humanitário, assim como - falando antropologicamente - da consciência de cooperação (internacionalização da sociedade, da rede de dados, opinião pública mundial, das demonstrações com temas de política externa, legitimação externa).
}

${ }^{130}$ ABADE, Denise Neves, op. cit., p. 63.

${ }^{131}$ WALD, Arnoldo, Confiança (Princípio da), in Dicionário de Princípios Jurídicos, p. 173 
internacional em matéria penal, esse princípio está intimamente associado à segurança pública. Afinal, no período pós-guerra, as nações entenderam por bem manter a paz e a segurança internacionais, desenvolvendo relações amistosas e a cooperação internacional, com harmonização de normas, para resolver problemas internacionais de caráter econômico, social, cultural ou humanitário, estimulando-se o respeito aos direitos humanos ${ }^{132}$.

Destarte, o princípio da confiança representa o fundamento a partir do qual é possível identificar os fatores que podem contribuir para uma assistência jurídica internacional em matéria penal mais eficiente ${ }^{133}$.

Cada vez mais, almeja-se incrementar a cooperação jurídica internacional em matéria penal, existindo um crescente anseio pela aproximação e harmonização das diversas legislações existentes. Nesse sentido, a constitucionalização de valores assegurados pelos direitos humanos é fundamental.

Em um Estado de Direito democrático Prado ${ }^{134}$ afirma que:

"[...] a determinação dos valores sociais da comunidade deve estar, em princípio, delineada na Constituição. O aspecto substancial dos valores constitucionais relaciona-se com a definição de um espaço aberto que torne possível o jogo das alternativas, facultando a qualquer idéia ou tendência a oportunidade de vier a ser majoritária. [...]. Faz-se mister um mínimo de consenso ético sobre os valores fundamentais para a existência do homem, da sociedade e do grau de homogeneidade cultural ou de (objetiva) compatibilidade recíproca - e também de (subjetiva) capacidade de tolerância - entre as diversas visões do mundo difusas nos grupos sociais. A credibilidade do ordenamento jurídico e do Direito Penal, em particular, varia de acordo com a quantidade de consenso social, em que se alicerça."

Quiçá a constituição de valores comuns, como os contidos nos direitos humanos ${ }^{135}$, seja capaz de propiciar uma cooperação mais equilibrada, sem que sejam

\footnotetext{
${ }^{132}$ Ver propósitos e princípios da Carta das Nações Unidas, Decreto 19.841/45.

${ }^{133}$ BECHARA, Fábio Ramazzini. op. cit., p.150

${ }^{134}$ PRADO, Luiz Regis. Bem jurídico-penal e constituição, p. 75.
} 
desrespeitadas as diversidades culturais de cada nação. Evidentemente cada área da cooperação internacional tem os seus próprios valores.

Conforme preleciona Tavares ${ }^{136}$ : “A condição humana ou o princípio da humanidade limita o ato de cooperação penal na medida em que não será admissível um tratado que exija os afetados pelo ato de coação o cumprimento de obrigações impossíveis, ou que desconsidere os acordos internacionais de proteção dos direitos do homem”.

De acordo com Bechara ${ }^{137}$ :

"Destarte, não obstante a cooperação jurídica deva ser o mais ampla possível, garantindo-se o maior dinamismo no processamento da cooperação jurídica internacional em matéria penal e melhora da eficácia da prova têm por base o respeito aos direitos humanos, a partir da perspectiva de que o ideal universalista dos direitos humanos conduz à existência de um padrão normativo, inclusive em relação às garantias processuais."

\subsection{Considerações gerais acerca das classificações da cooperação jurídica internacional}

Neste passo, é oportuno apontar breves considerações quanto às diversas classificações da cooperação jurídica internacional em matéria penal.

Como é cediço, a cooperação jurídica internacional pode se dar quer no âmbito vertical, quer no âmbito horizontal. No âmbito vertical, ocorrerá quando houver a necessidade de interação jurídica entre Estados e uma Corte ou órgão supraestatal.

\footnotetext{
135 Conforme assevera PIOVESAN, Flavia. Igualdade, Diferença e Direitos Humanos: Perspectiva Global e Regional, p. 47. "A ética dos direitos humanos é a ética que vê no mundo um ser merecedor de igual consideração e profundo respeito, dotado do direito de desenvolver as personalidades humanas de forma livre, autônoma e plena. É a ética orientada pela afirmação da dignidade e pela preservação ao sofrimento humano".

${ }^{136}$ CERVINI, Raúl e TAVARES, Juarez. Princípios de Cooperação Judicial Penal Internacional no Protocolo do Mercosul, p.199.

${ }^{137}$ BECHARA, Fávio Ramazzini. op.cit., p. 58.
} 
Já no âmbito horizontal, ocorrerá quando houver necessidade de interação jurídica de Estados que se encontram em um mesmo plano, representando uma cooperação interestatal $^{138}$.

O escopo do presente trabalho limita-se à análise denominada cooperação jurídica internacional, no âmbito horizontal, em matéria penal ${ }^{139}$.

Quanto à iniciativa da solicitação, a cooperação jurídica pode ser classificada como ativa ou passiva. Será ativa, quando se referir a quem solicita a assistência , e passiva, quando se referir a quem é solicitada a cooperação ${ }^{140}$.

No caso, serão analisadas somente as hipóteses de cooperação ativa, nas quais o Brasil é o país requerente, afinal almeja-se estudar os reflexos da prova produzida no exterior, no interesse do processo penal brasileiro.

Quanto a seus objetivos, pode-se asseverar, conforme consta do portal do Ministério da Justiça ${ }^{141}$, que a cooperação jurídica internacional se divide em: "(i) atos de comunicação processual: citação, intimação ou notificação; (ii) obtenção de provas: quebra de sigilo bancário, telefônico, telemático, oitiva de testemunhas, interrogatório, documentos e informações; e (iii) medidas cautelares, perdimento e repatriação de ativos" ${ }^{\prime 142}$.

\footnotetext{
${ }^{138}$ GEMAKE, Silvio César Arouck. A necessária influência do processo penal internacional no processo penal brasileiro, p. 68. Ao fazer e diferencia acima exposta, entre a cooperação horizontal e a vertical esclarece que: "O primeiro tipo de cooperação é modelo clássico e que tem se desenvolvido historicamente há muitos séculos, desde o primeiro tratado celebrado, sendo que, inclusive em União de Estados, como é o caso da União Européia, como se verifica do terceiro pilar, é ainda instrumento importante para a solução de diferentes problemas que não envolvem aspectos supranacionais da União. Já o segundo modelo de cooperação refere-se àquele que ocorre no bojo das instituições multilaterais, como o Tribunal Penal Internacional, propriamente quanto às principais características da cooperação internacional existente entre Cortes Penais e os países signatários dos tratados multilaterais que tenham dado ensejo a tais órgãos".

139 Sendo certo que a priori não existe uma obrigatoriedade de cooperação entre os Estados, ressalvadas as hipóteses de cooperação vertical com o Tribunal Penal Internacional e as decisões do Conselho das Nações Unidas, para preservação da paz e segurança. (Carta de São Francisco).

${ }^{140}$ BECHARA, Fábio Ramazzini. op. cit., p. 44.

${ }^{141}$ portal.mj.gov

${ }^{142}$ Ver MORO, Sérgio Fernando. Cooperação jurídica internacional em casos criminais: considerações gerais, p. 18/9. "No âmbito criminal, sem pretender ser exaustivo, os pedidos de cooperação podem ter por objeto: a) atos de comunicação de atos jurídicos, como a citação e intimação; b) produção de provas, quando, por exemplo, se requer a oitiva de uma testemunha o colheita de prova documental; c) a efetivação de medidas de cunho assecuratório, como arresto ou seqüestro de bens; d) a efetivação de decretos de confisco criminal; e e) a extradição, com eventualmente prévia prisão do extraditando".
} 
O foco deste trabalho limita-se à análise do auxílio no cumprimento de atos instrutórios e cautelares indispensáveis à obtenção de prova, no curso do processo penal, quando o Brasil for o país requerente (cooperação ativa).

A cooperação jurídica pode ainda ser distinguida pelo critério de quem coopera. Segundo Bechara ${ }^{143}$, ela se divide em cooperação entre autoridades judiciais (cooperação jurídica judicial) ou entre autoridades não judiciais (cooperação jurídica administrativa). Para análise das questões afetas à prova, serão apreciadas as duas hipóteses.

Outra maneira de distinguir a cooperação jurídica em matéria penal é por sua forma, podendo ser direta (informal), quando realizada entre as Polícias (Interpol), Ministério Público, Magistrados, pelas Unidades de Inteligência Financeira (“UFI”), ou jurídica (formal), nesse caso, realizada entre as Autoridades Centrais ${ }^{144}$ (o que assegura a autenticidade e a legalidade dos documentos) e órgãos diplomáticos, com base em Tratados e Convenções de Auxílio Jurídico Mútuo e legislação local do país ${ }^{145}$.

Conforme preleciona Souza ${ }^{146}$, "a cooperação direta tem lugar quando a solicitação da medida pode ser feita diretamente entre autoridade requerida e autoridade requerente, sem a necessidade de instauração ou participação de instâncias formais e independentemente da intervenção do Poder Judiciário”.

Por sua vez: a cooperação formal:

\footnotetext{
${ }^{143}$ BECHARA, Fábio Ramazzini. op. cit., p. 45.

${ }^{144}$ Ver portal.mj.gov.br. A autoridade central "é órgão técnico, exclusivo ou não, designado por cada um dos Estados Partes de um tratado para centralizar comunicações e ações de cooperação jurídica internacional" (convenção de Haia), suas principais atribuições são "tramitar os pedidos de cooperação jurídica internacional, coordenar a cooperação jurídica internacional e estabelecer um canal central e direto de comunicação com jurisdições estrangeiras." Conforme estabelece o artigo 11, da Decreto Lei 6.061/07. "Ao departamento de Recuperação de Ativos e Cooperação Jurídica Internacional compete: IV - exercer a função de autoridade central para tramitação de pedidos de cooperação jurídica internacional [...] VI - instruir, opinar e coordenar a execução da cooperação jurídica internacional ativa e passiva, inclusive cartas rogatórias". Não obstante a atribuição para processamento da cooperação jurídica internacional esteja concentra no DRCI, existem exceções a esta regra. A Procuradoria Geral da República é a autoridade central para a cooperação jurídica internacional com relação: (i) a Convenção sobre Prestação de Alimentos no Estrangeiro, de 1956 (Decreto 56.862/65); (ii) ao Tratado de Auxílio Mútuo em Matéria Penal entre Portugal e o Brasil (Decreto 1320/94); e (iii) ao Tratado de Assistência Mútua em Matéria Penal entre o Brasil e o Canadá (Decreto 6747/09).

${ }^{145}$ Ver portal da internet do Ministério da Justiça. portal.mj.gob.br.

${ }^{146}$ SOUZA, Carolina Yumi de. Cooperação jurídica internacional em matéria penal: considerações práticas, $\mathrm{p}$. 306.
} 
“[...] tem lugar quando é necessária a institucionalização da via escolhida ou para garantir a validade da prova a ser produzida ou do ato a ser executado ou, ainda, quando se faz necessária a intervenção judicial para sua execução. Em matéria penal, os instrumentos comumente utilizados são o auxílio direto e a carta rogatória. A cooperação formal, assim, é necessária quando tiver por objeto: 1 . Atos judiciais de comunicação (citação, intimação, notificação), 2. Atos judiciais relacionados à produção de prova (testemunhos, perícias), 3. Atos judiciais de natureza cautelar (medidas assecuratórias), 4. Atos judiciais definitivos (sentenças, extradição) e 5. Atos destinados a integrar o processo penal."147

Além dessas hipóteses, a cooperação jurídica pode se dar mediante a existência de tratados bilaterais ou multilaterais ${ }^{148}$, ou - sem a existência dessas normas - pautando-se pelos princípios da solidariedade, reciprocidade e em observância dos $\operatorname{costumes}^{149} \mathrm{e}$ princípios do direito internacional.

Outra forma de distinção da cooperação jurídica internacional é pelo instrumento utilizado $^{150}$, podendo a colaboração entre os diversos Estados- Nação se dar por meio da carta

\footnotetext{
${ }^{147}$ SOUZA, Carolina Yumi de. Cooperação jurídica internacional em matéria penal: considerações práticas, p. 307.

${ }^{148}$ Conforme informações do sitio da internet www.mj.gov.br, dentre outros, o Brasil é signatário dos seguintes tratados multilaterais e bilaterais: Convenção Interamericana sobre prova e informação acerca do direito estrangeiro (Decreto 1925/96); Convenção Interamericana sobre Cartas Rogatórias (Decreto 1899/96) e Protocolos adicionais (Decreto 2022/96); Convenção Interamericana sobre Assistência Mutua em Matéria Penal (Decreto 6340/08); Protocolo de Medidas Cautelares (262/98); Protocolo de Assistência Jurídica Mutua em matéria penal (Decreto 3468/00); Protocolo de Assunção sobre Compromisso com a Promoção e Proteção dos Direitos Humanos no Mercosul (Decreto 7225/10); Convenção das Nações Unidas contra Corrupção (5687/06); Convenção das Nações Unidas contra o Crime Organizado Transnacional (Decreto 5015/04). Acordos bilaterais com: a China (Decreto 9282/07); Coreia (Decreto 5721/06); Estados Unidos da América (Decreto 3810/01); Colômbia (Decreto 3895/01); Peru (Decreto 3988/01); França (Decreto 3324/99); Itália (Decreto 862/93); Portugal (Decreto 1320/94) etc.
}

${ }^{149}$ TRINDADE, Antônio Augusto Cançado. A humanização do Direito Internacional, p. 36. "O próprio artigo 38 do Estatuto do CJI qualifica devidamente o costume internacional ao se referir a ele como 'prova de uma prática geral aceita como sendo o direito'. Donde os dois elementos clássicos constitutivos do costume: o elemento objetivo, representado pela própria prática internacional, e o elemento subjetivo, a opinio juris sivenecessitatis, i.e., a convicção de que tal prática é de direito e aceita como tal. Tal configuração do costume internacional é ainda a predominante aceita em nossos dias".

${ }^{150}$ Manual de Cooperação Jurídica Internacional e Recuperação de Ativos. Cooperação em Matéria Penal, do DRCI, 2008. "O intercâmbio internacional para o cumprimento de medidas processuais em matéria penal não se dá apenas por intermédio da clássica carta rogatória, regida pelas normas estipuladas nos artigos 783 e seguintes 
rogatória, extradição, auxílio direto, dentre outras formas. Dar-se-á preferência à análise da carta rogatória e do auxílio direto em matéria penal (judicial ou administrativo) ${ }^{151}$, destinados às questões probatórias e abrangendo, inclusive, as medidas de caráter coercitivo que tiverem essa finalidade.

\subsection{Apontamentos sobre os instrumentos utilizados pela cooperação jurídica internacional em matéria de prova}

O mecanismo formal tradicionalmente mais utilizado na cooperação jurídica internacional em matéria penal para a produção de prova, quando o Brasil é o estado requerente, é a carta rogatória, empregada geralmente quando a prática de um ato deva ser efetuada em país estrangeiro.

Destarte, a carta rogatória consiste "no instrumento pelo qual se solicita a prática de diligência à autoridade judicial estrangeira, utilizando principalmente para comunicação de atos processuais. Ou ainda, o instrumento de ordem necessário à comunicação de que atos processuais precisam ser realizados fora do território do Estado", de acordo com Bechara ${ }^{152}$.

Araújo ${ }^{153}$, por sua vez, esclarece que "as cartas rogatórias destinam-se ao cumprimento de diversos atos, como citação, notificação e cientificação, denominados ordinários ou de mero trâmite; de coleta de prova, chamados instrutórios. É o veículo de transmissão de qualquer pedido judicial, podendo ser de caráter cível ou criminal”.

do Código de Processo Penal. Verifica-se, também, a possibilidade de elaboração de pedido de auxílio jurídico direto, regido pelo Direito Internacional costumeiro, com respaldo no artigo $4^{\circ}$, da Constituição Federal, e por diversos tratados bilaterais, regionais e multilaterais firmados pelo Brasil."

${ }^{151}$ Conforme acentuado por GUEIROS, Artur. Cooperação penal no MERCOSUL. Seminário da Escola Superior do Ministério Público Federal realizado no Rio Grande do Sul, out. 2001, a cooperação entre os Estado em matéria penal possui três ramos: (i) auxílio no cumprimento de atos instrutórios e cautelares necessários ao desenvolvimento de determinado processo; (ii) colaboração na localização de detenção de acusado, para que responda processo ou cumpra pena já estabelecida - extradição; e (iii) colaboração na produção de efeitos, no território de uma sentença penal condenatória, havida em outro Estado. In:.

${ }^{152}$ BECHARA, Fábio Ramazzini. op. cit., p. 51.

${ }^{153}$ ARAÚJO, Nádia de. A importância da Cooperação Jurídica Internacional para a Atuação do Estado Brasileiro no Plano Internacional, in DRCI. Manual de Cooperação Jurídica Internacional e Recuperação de Ativos. Cooperação em Matéria Penal, p. 43. 
No sistema jurídico brasileiro, a carta rogatória ${ }^{154}$ é regida por dispositivos do Código de Processo Civil (artigo 210), do Código de Processo Penal (artigos 222, $\S \S 1^{\circ}$ e $2^{\circ}$, 222-A e 783 a 786), da Constituição Federal (art. 105, inciso I, alínea $i$ ) e por meio de tratados internacionais, bilaterais ou multilaterais, por exemplo, a Convenção Interamericana de Cartas Rogatórias - Decreto 1899/96 e o Protocolo adicional à Convenção Interamericana de Cartas Rogatórias - Decreto 2.022/96).

Quanto à forma de tramitação das cartas rogatórias ativas, Machado ${ }^{155}$ esclarece que:

“[...] são encaminhadas ao DRCI-MJ pela autoridade judiciária ou pelo interessado (advogado ou parte). O DRCI, após abertura de um processo, verifica se a carta cumpre os requisitos legais. Em caso negativo, o DRCI-MJ devolve ao juízo rogante para os ajustes e correções necessários, um procedimento que pode se repetir até que a carta esteja apta ao cumprimento no país destinatário. Uma vez instruída, a forma de encaminhamento ao país destinatário dependerá da existência de acordo internacional entre os dois países. Se não houver acordo, o DRCI encaminha à Divisão Jurídica do Departamento Consular do Ministério das Relações Exteriores, para que eles tramitem, por via diplomática, ao país destinatário.”

No que se refere à produção de provas, além desse instrumento de colaboração, existe o novel auxílio direto ${ }^{156}$ que tramita por meio das autoridades centrais ${ }^{157}$, “é utilizado,

\footnotetext{
${ }^{154}$ As cartas rogatórias podem ser ativas, ou passivas. Em geral, a maior dificuldade de processamento dos pedidos jurídicos cooperacionais refere-se à carta rogatória passiva, por questões de soberania nacional, não sendo esta análise objeto do presente trabalho.

${ }^{155}$ MACHADO, Maíra Rocha. Cooperação Penal Internacional no Brasil: as cartas rogatórias passivas. In Revista Brasileira de Ciências Criminais 53, p. 101.

${ }^{156}$ Note-se que a terminologia utilizada para este instrumento é vasto. Ver. SOUZA, Solange Mendes de. Cooperação jurídica Penal no MERCOSUL: Novas Possibilidades, p. 133/5. Conforme exemplifica a autora utiliza-se "“cooperação jurídica internacional' no Projeto de lei 4.905 de 1995 e por Bergman; 'assistência jurídica interjudicial', empregada por Bermúdez; ou 'cooperação jurisdicional', por Badán, por entender o termo jurisdicional mais amplo que o termo judicial

${ }^{157}$ Atualmente não há mais uma hegemonia da diplomacia na cooperação jurídica internacional, não cabe mais a diplomacia manejá-la isoladamente, diante da complexidade das relações internacionais dos Estados. Não se está falando aqui de "paradiplomacia", expressão bastante criticada (por que tida como fora do direito), mas sim de relações internacionais manifestadas pelo poder executivo e ministérios. Vivenciamos uma gradual substituição
} 
em regra, quando um Estado, a fim de subsidiar procedimento em trâmite perante o seu próprio território, necessidade providência judicial a ser obtida em outra jurisdição" ${ }^{\text {158 }}$.

O auxílio direto ${ }^{159}$ (amplamente utilizado no direito europeu ${ }^{160}$ ) surgiu diante da necessidade de se dar maior celeridade e eficácia à assistência mútua em matéria penal ${ }^{161}$, em especial na apuração de infrações penais realizadas de forma globalizada, e que produzem resultados em diversos Estados.

Buscou-se, com esse instrumento ${ }^{162}$, a criação de meios capazes de operacionalizar com efetividade a apuração de ilícitos penais e combate a crimes

da atividade de contato internacional do Estado brasileiro com outras soberanias colocando o Ministério da Justiça no papel anteriormente exercido pelo ministério das relações exteriores, no que se refere aos processos de cooperação, cabendo, entretanto, ao Itamaraty, dentre outras funções, o papel de decidir com quem o Brasil deve cooperar. Atualmente cada vez mais se deixa menos com o Itamaraty a análise dos processos de cooperação jurídica internacional, embora a atuação deste órgão diplomático (de grande qualidade) seja fundamental em casos nos quais inexistam tratados de cooperação jurídica internacional. Palestra sobre o papel dos órgãos internos em cooperação jurídica internacional, de BONI SOARES, do dia 15.06.10, em aula de final do curso de Cooperação jurídica Internacional, na pós graduação, da Faculdade de Direito da USP, Largo São Francisco.

${ }^{158}$ TOFFOLI, José Antonio Dias e CESTARI, Virgínia Charpinel Junger, Manual de cooperação jurídica internacional em Matéria Penal, p. 27.

${ }^{159}$ Sobre a distinção entre Carta Rogatória e Auxilio Direito ver: Carmen Tiburcio, Temas de Direito Internacional. p. 475. “[...] O elemento decisivo é se (1) se tratar de dar efeito direto a uma decisão de autoridade estrangeira - para o que se exige a carta rogatória - ou (2) se a hipótese diz respeito a um pedido de colaboração, no qual o juízo de cabimento da medida compete à autoridade brasileira." Não se pode negar que no "contexto da cooperação interjurisdicional, a importância das cartas rogatórias é enorme, sendo o instrumento por excelência de todo o procedimento de cooperação. Para que um ato requerido por um país estrangeiro seja realizado em outro, é necessária a comunicação entre os poderes judiciários, o que se faz através do instrumento de carta rogatória". (Cooperação judiciária internacional, PAULO BORBA CASELLAe RODRIGO ELIAN SANCHEZ. Org.,p. 6)

${ }^{160}$ Art. 3, I, da Convenção de Auxilio Judicial Mútuo da União Européia.

${ }^{161}$ BECHARA, Fábio Ramazzini. cooperação jurídica internacional em matéria penal. Eficácia da prova produzida no exterior. São Paulo: Saraiva, 2011, p. 55 "a gênese do instrumento do auxílio direto está evidentemente associada à ineficiência das cartas rogatórias, notadamente, pelo fato de que as medidas de caráter executivo solicitadas sempre foram consideradas atentatórias à soberania nacional. A partir do instante em que a autoridade central nacional passa a agir por provocação da autoridade estrangeira tendo plena autonomia e controle sobre o mérito e formalidades do pedido, escusa-se do recurso à soberania como argumento de autoridade a impedir a cooperação. A propósito da ausência de previsão Constitucional, o Ministro Marco Aurélio, no julgamento do HC 85.588/RJ (STF - julgado em 5-3-2005), considerou que 'o empréstimo do rótulo de procedimento de cooperação internacional a certo instrumento não pode desaguar na prática de atos somente passíveis de serem alcançados por meio da carta rogatória, como são aqueles ligados à audiência de instrução, visando à persecução criminal. A cooperação há de se fazer com respeito irrestrito à organicidade de Direito nacional, reafirmando-se a República como revelada por um Estado Democrático de Direito, para tanto se mostrando indispensável que se homenageie a máxima segundo a qual o meio justifica o fim (Brasilia, 2006)".

${ }^{162} \mathrm{O}$ auxílio direto podendo necessitar ou não de decisão jurisdicional, ocorrendo em alguns casos pela via administrativa. Nos casos em que o auxilio direto necessita de decisão judicial, o pedido em matéria penal chega por meio do Ministério Público Federal. 
transnacionais ${ }^{163}$, ampliando-se, portanto, os mecanismos de cooperação jurídica internacional.

Miller ${ }^{164}$ enfatiza que "o auxílio direto em matéria penal constitui método de cooperação pelo qual um Estado solicita a outro, a que toca a jurisdição relevante, medida judicial ou administrativa necessária ou útil ao processo penal ou investigação policial”.

O autor aponta os pressupostos do auxílio direto:

“O desdobramento dessa definição conduz à identificação dos seguintes pressupostos do auxilio direto: (i) existência de um processo penal ou investigação criminal em determinado Estado; (ii) necessidade ou utilidade, para o processo penal ou a investigação criminal, de medida judicial ou administrativa; (iii) pertinência a outro Estado da jurisdição judiciária ou administrativa para a medida judicial ou administrativa."

Diversamente do que ocorre na carta rogatória, na qual se exige somente um juízo de delibação por parte do Estado requerido, no auxílio direto há necessidade do deferimento pelo outro Estado de uma pretensão processual ordinatória, instrutória ou assecuratória. Nesse sentir, "a prestação de auxilio direto revela exercício de jurisdição própria pelo Estado auxiliador, baseada em seu interesse nacional em cooperar e em seus princípios constitucionais", nas palavras de Oliveira Miler ${ }^{165}$.

De acordo com Bechara ${ }^{166}$, no Brasil inexiste previsão constitucional para o pedido de auxilio direto, embora o país seja signatário de diversos tratados internacionais que preveem esse instrumento de cooperação jurídica.

\footnotetext{
${ }^{163} \mathrm{O}$ Brasil vem firmando diversos tratados internacionais, de auxilio mútuo em matéria penal visando, sobretudo minimizar as grandes dificuldades enfrentadas na investigação de crimes internacionais. Não obstante a importância do tema acerca da relativização ou não da soberania nacional, esta questão foi tangenciada de forma sucinta anteriormente.

${ }^{164}$ OLIVEIRA MILER, Marcello Paranhos de. op. cit.,p. 81.

${ }^{165}$ OLIVEIRA MILER, Marcello Paranhos de. op. cit., p. 83.

${ }^{166}$ Ver BECHARA, Fábio Ramazzini. op. cit., p. 55.
} 
Note-se, ainda, que, para fins de investigação criminal, hodiernamente tem-se utilizado, com frequência, a cooperação não jurisdicional ou direta, realizada entre as polícias (por exemplo, INTERPOL) e os Ministérios Públicos, diretamente, sem intermediários.

Não obstante, graças à cooperação das denominadas Law enforcement agencies dos diversos Estados, esteja ocorrendo um incremento na descoberta de grandes esquemas criminosos, permitindo a obtenção de provas desses ilícitos transfronteiriços com maior agilidade, não se há de negar que tais mecanismos, por vezes, acabam por violar direitos fundamentais dos acusados, indispensáveis ao justo processo, conforme se verá mais adiante.

Tais redes de cooperação jurídica:

“[...] são formadas por pontos de contato nacionais, designados por autoridades dos Ministérios Públicos, Poder Judiciário e demais entes envolvidos na cooperação jurídica, os quais centralizam temas de cooperação nacionalmente, e atuam como intermediários na intensificação da cooperação entre seu país e os demais membros da rede. Mais do que desempenhar um papel estritamente burocrático, as redes buscam facilitar a cooperação por meio de contatos informais, trocas de informações, remarcação de audiências, exames preliminares em pedido de auxílio." 167

Imprescindível mencionar que a cooperação jurídica internacional, para obtenção de provas pela via da diplomacia, não foi descartada, sendo geralmente utilizada na hipótese de ausência de tratados internacionais ou, ainda, pela defesa.

Nesse sentido, Lima e Aras ${ }^{168}$ enfatizam ser "possível a obtenção de provas no exterior mediante consularização de documentos, sem intervenção da autoridade central

\footnotetext{
${ }^{167}$ www.ascji.pgr.mpf.gob.br/atuacao-da-ccji/redes-de-cooperacao-juridica. “Atualmente o Brasil faz parte de três redes de cooperação jurídica internacional, Rede Ibero-Americana de Cooperação Judicial (IberRED), Rede de Cooperação Jurídica e Judiciária Internacional dos Países de Língua Portuguesa (Rede Judiciária da CPLP) e Rede Hemisférica de intercâmbio de Informações para o Auxilio Jurídico Mútuo em Matéria Penal e de Extradição".

${ }^{168}$ LIMA, Luciano Flores de e ARAS, Vladimir. "Cooperação Internacional Direta pela Polícia ou Ministério Público", in Cooperação Jurídica Internacional em Matéria Penal, José Paulo Baltazar Júnior e Luciano Flores de Lima (org.), Curitiba: Verbo Divino, 2010, p. 140.
} 
brasileira ou estrangeira. Esse método revela-se útil especialmente para a defesa, que não necessita seguir todos os passos da burocracia estatal para obtenção de provas fora do país".

A obtenção de prova por cooperação jurídica internacional pode se dar ainda pela via unilateral, com a entrega espontânea, na qual um Estado, voluntariamente, entrega a outros Estados documentos e informações relativas à prova existentes naquele país. 
Para que se possa analisar a produção de prova por meio da cooperação jurídica internacional, torna-se indispensável tecer considerações acerca da prova e de sua validade no sistema jurídico brasileiro, essencial ao justo processo.

Ao longo deste capítulo, procura-se refletir acerca do conceito, da finalidade e da admissibilidade da prova a ser produzida por meio da cooperação jurídica internacional.

Como é cediço, o direito à prova possui extrema importância no âmbito do processo penal, posto é que nas provas que as partes, acusação e acusado, irão fundamentar as alegações finais, e é por meio de seu exame que o juiz formulará sua convicção, proferindo sentença $^{169}$.

Partindo-se do dilema existência do processo penal (preservação do jus libertatis e do jus puniendi), o processo penal assume contornos relevantíssimos, de modo que a produção da prova e sua admissibilidade devem se dar em respeito às garantias do devido processo legal, da ampla defesa e do contraditório.

Nesse sentido, há que se garantir aos acusados, no que se refere à produção de provas, segundo Lauria ${ }^{170}$ : (i) prévio conhecimento do teor da acusação que lhe pesa e dos elementos probatórios existentes nos autos; (ii) assistência real e efetiva, de defensor, particular ou dativo, para elaboração da defesa técnica; (iii) informação do direito de permanecer calado, sem que lhe seja feita qualquer ameaça (física ou verbal) ou que lhe sejam impostas medidas que prejudiquem sua memória ou compreensão; (iv) informação de que não tem o dever de contribuir ativamente para elucidação dos acontecimentos, sendo-lhe, portanto, facultado o fornecimento de sangue, grafia, e outros; (v) comunicação com advogado, antes da realização do interrogatório, em tempo hábil à preparação da ampla defesa, preservando-se a livre manifestação da vontade; (vi) possibilidade efetiva de requerer a produção de provas; (vii) possibilidade em iguais condições de contrapor a prova produzida pela parte contrária, com participação ativa; (viii) respeito aos critérios legais e constitucionais acerca da admissibilidade da prova; (ix) respeito à vida privada, à intimidade, à moradia, dentre outros de igual magnitude e (x) direito à escorreita valoração da prova.

\footnotetext{
${ }^{169}$ LIMA, Marcellus Polastri. op. cit.,p. 54.

${ }^{170}$ TUCCI, Rogério Lauria. Princípios e regras orientadoras do processo penal brasileiro, p. 399.
} 
Observe-se, que além dessas, ínsitas ao exercício do contraditório ${ }^{171}$, os tratados internacionais de direitos humanos ${ }^{172}$ preconizam ao acusado uma série de garantias, sem as quais inexistirá o justo processo.

O artigo $8^{\circ}$ da Convenção Americana de Direitos Humanos dispõe que:

“1. Toda pessoa terá o direito de ser ouvida, com as devidas garantias e dentro de um prazo razoável, por um juiz ou Tribunal competente, independente e imparcial, estabelecido anteriormente por lei, na apuração de qualquer acusação penal formulada contra ela, ou na determinação de seus direitos e obrigações de caráter civil, trabalhista, fiscal ou de qualquer outra natureza.

2. Toda pessoa acusada de um delito tem direito a que se presuma sua inocência, enquanto não for legalmente comprovada sua culpa. Durante o processo, toda pessoa tem direito, em plena igualdade, às seguintes garantias mínimas:

3. direito do acusado de ser assistido gratuitamente por um tradutor ou intérprete, caso não compreenda ou não fale a língua do juízo ou tribunal;

\footnotetext{
${ }^{171}$ Ver a clássica definição de contraditório proferida por ALMEIDA, Joaquim Gomes de, Princípios fundamentais do Processo Penal, São Paulo: RT, 1973, p. 82. "O contraditório é, pois, em resumo, ciência bilateral dos atos e termos processuais e possibilidade de contrariá-los. A contrariedade é a ação das partes. Tem suas raízes naturais no conflito de interesses e se manifesta processualmente na representação desse conflito diante do juiz"”.

${ }^{172}$ Ver também artigo $6^{\circ}$, da Convenção Europeia de Direitos Humanos: "Direito a um processo equitativo. 1. Qualquer pessoa tem direito a que a sua causa seja examinada, equitativa e publicamente, num prazo razoável por um tribunal independente e imparcial, estabelecido pela lei, o qual decidirá, quer sobre a determinação dos seus direitos e obrigações de carácter civil, quer sobre o fundamento de qualquer acusação em matéria penal dirigida contra ela. O julgamento deve ser público, mas o acesso à sala de audiências pode ser proibido à imprensa ou ao público durante a totalidade ou parte do processo, quando a bem da moralidade, da ordem pública ou da segurança nacional numa sociedade democrática, quando os interesses de menores ou a proteção da vida privada das partes no processo o exigirem, ou, na medida julgada estritamente necessária pelo tribunal, quando, em circunstâncias especiais, a publicidade pudesse ser prejudicial para os interesses da justiça. 2. Qualquer pessoa acusada de uma infracção presume-se inocente enquanto a sua culpabilidade não tiver sido legalmente provada. 3. O acusado tem, como mínimo, os seguintes direitos: a) Ser informado no mais curto prazo, em língua que entenda e de forma minuciosa, da natureza e da causa da acusação contra ele formulada; b) Dispor do tempo e dos meios necessários para a preparação da sua defesa; c) Defender-se a si próprio ou ter a assistência de um defensor da sua escolha e, se não tiver meios para remunerar um defensor, poder ser assistido gratuitamente por um defensor oficioso, quando os interesses da justiça o exigirem; d) Interrogar ou fazer interrogar as testemunhas de acusação e obter a convocação e o interrogatório das testemunhas de defesa nas mesmas condições que as testemunhas de acusação; e) Fazer-se assistir gratuitamente por intérprete, se não compreender ou não falar a língua usada no processo”.
} 
4. Comunicação prévia e pormenorizada ao acusado da acusação formulada;

5. Concessão ao acusado do tempo e dos meios necessários à preparação de sua defesa;

6. Direito ao acusado de defender-se pessoalmente ou de ser assistido por um defensor de sua escolha e de comunicar-se, livremente e em particular, com seu defensor;

7. Direito irrenunciável de ser assistido por um defensor proporcionado pelo estado, remunerado ou não, segundo a legislação interna, se o acusado não se defender ele próprio, nem nomear defensor dentro do prazo estabelecido pela lei;

8. Direito da defesa de inquirir as testemunhas presentes no tribunal e de obter o comparecimento, como testemunhas ou peritos, de outras pessoas que possam lançar luz sobre os fatos;

9. Direito de não ser obrigada a depor contra si mesma, nem a confessar-se culpada;

10. O acusado absolvido por sentença transitada em julgado não poderá ser submetido a novo processo pelos mesmos fatos.

11. O processo penal deve ser público, salvo no que for necessário para preservar os interesses da justiça. “

Além disso, é indispensável à existência de um procedimento legalmente préestabelecido, afinal, como assevera Beccaria ${ }^{173}$, "as formalidades e o cerimonial são indispensáveis à administração da justiça, quer porque nada deixam ao arbítrio de quem a administra, quer porque sugerem ao povo um julgamento não-tumultuário e parcial, mas sim estável e regular que, enfim, porque as sensações, mais do que o raciocínio, produzem impressões eficazes sobre os homens imitadores e escravos do hábito". Evidentemente que isto não significa que se apregoe o formalismo pelo formalismo.

\footnotetext{
${ }^{173}$ BECCARIA, Cesare. Dos delitos e das penas, p. 133
} 
Reportando a Bertolini ${ }^{174}$, o Estado deve reconhecer ao governado, de forma inescusável, um processo penal institucionalmente estabelecido.

\subsection{Considerações gerais sobre a prova e indícios.}

Conforme conceitua Abbagnano ${ }^{175}$, a palavra prova constitui um procedimento apto a estabelecer um saber, isto é, um conhecimento válido, qualquer que seja sua natureza. É um termo mais extenso que a demonstração, posto que as demonstrações são provas, mas nem toda prova é demonstração.

Juridicamente, embora não seja um termo unívoco, a prova ${ }^{176}$, em essência, é o meio material pelo qual se evidencia o fato sobre o qual se desencadeia o direito. Nem todo meio material, por si, entretanto, está revestido do elemento probatório a desencadear qualquer direito.

Florian $^{177}$ entende que "provar é fornecer, no processo, o conhecimento de qualquer fato, adquirindo, para si, gerando em outrem, a convicção da substância ou verdade do mesmo fato".

\footnotetext{
${ }^{174}$ BERTOLINI, Pedro J. El devido processo penal, p. 47. "Dicho de otro modo, estimamos que el Estado deberáreconocer al governado, inexcusavelmente, y sin más, um processo penal institucionalmente estabelecido. Estoconstituye um 'prius' (qué se debe); luego, por consecuencia, se perfilará el 'posterius' (como deberáresularse y actuarseese processo); laconjunción de ambos elementos constituirá, recién y em definitiva, lanoción compreensiva de lo 'debido'”.
}

${ }^{175}$ ABBAGNANO, Nicola. Dicionário de Filosofia, p. 805.

176 Ver MAIER, Julio B. J. DerechoProcesal Penal I. Fundamentos, p.858/9. "De todos modos, aun com limitaciones, el procedimento penal es, desde certo punto de vista, um método regulado juridicamente para averiguar la verdade acerca de una imputación. Com elfin de cumpliresamisónacude, de lamismamanera que todo processo de conocimientohitórico, a lfaprueba, por intermedia d lacuallas personas que intervienen em élintentan lograr precisiones acerca de lahipótesis que consituyesu objeto principal. Em general, llamamosprueba a todo aquello que, enel procedimento, representa elesfuerzo por incorporar los rastros o señales que conducen al conocimiento certo o probable de su objeto. Pero éste es sólo uno delso sentidos del concepto, puestambién acudimos a élcuando pretendemos seãnalarel resultado de laactividad probatória (por ej., elcontenido de este documento prueba tal circuntancia o hecho). Es certo, por ello, que 'el concepto deprueba es la sínteses de diversos aspectos, puesla figura de laprueba es poliédrica'. Sin embargo, em lo que ahora nos interessa, basta com aceptarel significado intuitivo, relacionado com conocer, comprovar, em fin, acercarnos a la verdade".

177 Tradução livre. Ver FLORIAN, Eugenio. De las pruebas penales, p. 44/5. "Probar significa suministrar em el processo elconocimiento de cualquierhecho, de manera que se adquiera para sí o se engendre em laconvicción de laexsistencia o verdade de esse hecho. Transladando estos critérios ao proceco penal, ellostienen valor em orden al conocimient y deldelincuente u de todos los elementos que elos se refieren o que com ellosestán vinculados; en este caso y em lo concernente a lanoción de prueba, no hai para qué distinguir si 
Malatesta" ${ }^{178}$ acentua que:

“[...] a prova pode ser considerada sob um duplo aspecto: quanto à sua natureza e produção, e quanto ao efeito que acarreta ao espírito daqueles perante quem é produzida. Sob este (sic) segundo aspecto, resolve-se na certeza, na probabilidade e na credibilidade. [...]. Como as faculdades perceptivas são a fonte subjetiva da certeza, assim as provas são o modo de apreciação da fonte objetiva, que é a verdade. A prova é, portanto, deste(sic) ângulo, o meio objetivo com que a verdade alcança o espírito; e como o espírito pode, relativamente a um objeto, chegar por via das provas tanto à simples credibilidade, como à probabilidade e à certeza, existirão assim provas de credibilidade, provas de probabilidade e provas de certeza. A prova, portanto, em geral é a relação concreto entre a verdade e o espírito humano nas suas especiais determinações de credibilidade, probabilidade e certeza."

Por sua vez, Mittermaier afirma que "provar é querer, em substância, demonstrar a verdade e convencer o juiz, o qual para decidir há mister de adquirir plena certeza" ${ }^{\prime 179}$, enquanto Carnelucci ${ }^{180}$ afirma que a prova consiste na "demonstração da verdade de um fato realizada pelos meios legais (modos legítimos)".

esta fuesuministrada por eljuez opor las partes. (...).Empero, si se le considera dentro del processo penal, laprueba se presenta por un doble aspecto fundamental, u asípuedehablarse de ella, em um sentido amplio, para designar el concepto de lo que se comprueba em eljuicio, u también em um sentido propio, restingido y específico, para indicar el concepto de lo que se comprueba em el judicio com médios idóneos de pruebaprocesalmente estabelecidos. Es bien sabido que lacomprobacíonpuedeconseguirse em eljuicio penal aunsinelaxuxilio de especialesmedios probatórios".

${ }^{178}$ MALATESTA, Nicola Framarino Dei. A lógica das provas em matéria criminal, p. 87.

${ }^{179}$ MITTERMAIER, C. J. A. Tratado da Prova em Matria Criminal ou Exposição Comparada dos princípios da prova em matéria criminal, etc., de suas diversas aplicações na Allemanha, em França, Na Inglaterra, etc., p. 77.

${ }^{180}$ CARNELUTTI, Francesco. La prueba civil, p. 42. 
Segundo Dinamarco ${ }^{181}$, "prova é um conjunto de atividades de verificação e demonstração, mediante as quais se procura chegar à verdade dos fatos relevantes para o julgamento".

Na terminologia processual, conforme escólio de Gomes Filho:

“[...] o termo prova é empregado com variadas significações: indica de forma mais ampla, o conjunto de atividades realizadas pelo juiz e pelas partes na reconstrução dos fatos que constituem o suporte das pretensões deduzidas e da própria decisão; também pode aludir aos instrumentos pelos quais as informações sobre os fatos são introduzidas no processo (meios de prova); e, ainda, dá o nome ao resultado dessas atividades. As duas primeiras acepções correspondem aos aspectos objetivos antes mencionados, enquanto a última está relacionada aos efeitos subjetivos que decorrem da atividade probatória.'

O autor acrescenta que a expressão envolve outras conotações de conteúdo nem sempre perceptível, de caráter emotivo, cuja utilização provoca no interlocutor sentimentos de aceitação. Esclarece que, do ponto de vista etimológico, "prova tem a mesma origem de probo (do latim, probatio e probus), termo que indica aprovação, confiança, correção" ${ }^{182}$.

Para Taruffo ${ }^{183}$, “o direito à prova implica a liberdade das partes de produzir provas sem sofrer quaisquer óbices injustificados, não significando, consequentemente, que o juiz não deva ou não possa dispor de ofício a realização de provas não requeridas pelas partes".

\footnotetext{
${ }^{181}$ DINAMARCO, Candido Rangel. Instituições de Direito Processual Civil, p. 43.

${ }^{182}$ GOMES FILHO, Antonio Magalhaes. Direito à prova no processo penal, p. 41/2.

183 Tradução livre TARUFFO, Michele. "Il diritto ala prova nel processo civile", in Rivista di Diritto Processuale, p. 90.
} 
Como significado jurídico, no entender de Camargo Aranha ${ }^{184}$, prova "representa os atos e os meios usados pelas partes e reconhecidos pelo juiz como sendo a verdade dos fatos alegados.

Analisando as diversas acepções do vocábulo "prova", Badaró ${ }^{185}$ acentua que o objeto da prova não é o fato em si mesmo, mas uma alegação que se faz sobre ele, de modo que o que se prova são as alegações dos fatos efetuadas pelas partes.

A Doutrina tradicional tem a preocupação de fazer algumas distinções sobre as quais não se pode deixar de considerar.

A primeira distinção refere-se ao conceito de fontes de prova e meios de prova, sendo certo que, nos dizeres de Badaró, "a distinção conceitual entre fontes e meios de prova não visa apenas a um refinamento e aperfeiçoamento do vocabulário técnico. Há também uma relevância prática: diferencia os sujeitos que podem dispor das fontes dos que têm disponibilidade sobre os meios de prova" ${ }^{186}$.

Enquanto as fontes de prova são destinadas às partes, que têm o ônus de provar suas alegações e antecedem o processo penal, existindo independentemente deste, os meios de provas $^{187}$ destinam-se ao juiz e só existem no processo, constituem os instrumentos pelos quais as fontes de prova entram no processo ${ }^{188}$.

Tal distinção será importante na análise da cooperação jurídica internacional em matéria penal, no sentido da delimitação de quem pode requerer à prova a ser produzida em

\footnotetext{
${ }^{184}$ CARMARGO ARANHA, Adalberto José Q. T. de. Da prova no processo penal, p. 5.

${ }^{185}$ BADARÓ, Gustavo Henrique Righilvahy Badaró. Ônus da Prova no Processo Penal, p. 159. "é de se destacar que o objeto da prova é sempre uma alegação de um fato e não o fato em si mesmo. Os fatos, em si mesmo, são acontecimentos que têm existência no mundo real. O fato ocorreu ou não, existiu ou não, não comportando adjetivações ou valorações. Aquilo que existe na realidade não pode ser verdadeiro ou falso; simplesmente existe. Verdadeiros ou falsos só podem ser nossos conhecimentos, nossas percepções, nossas opiniões, nossos conhecimentos, nossas percepções, nossas opiniões, nossos conceitos ou nosso juízo a respeito de um objeto. Os fatos debatidos no processo são enunciados sobre fatos do mundo real, isto é, aquilo que se diz em torno de um fato: é a enunciação de um fato e não o próprio fato. Em consequência, o objeto da prova não é o próprio fato. $O$ que se prova são as alegações dos fatos feitas pelas partes como fundamentos da acusação e da defesa. O que pode ser verdadeiro ou falso, verídico ou inverídico, ou 'probo', são as alegações sobre o fato".

${ }^{186}$ BADARÓ, Gustavo Henrique Righi Ivahy Badaró. Ônus da Prova no Processo Penal, p. 167.

${ }^{187}$ Os meios de prova podem ser: testemunhal, documental e pericial, não obstante exista discussão acerca da admissibilidade de outros meios de prova.

${ }^{188}$ Ver BADARÓ, Gustavo Henrique Righi Ivahy. Ônus da Prova no Processo Penal, São Paulo: RT, 2003 , p. $162 / 168$.
} 
outro Estado e quais são os meios de provas admitidos, diante da diversidade de sistemas jurídicos probatórios vigentes no mundo ${ }^{189}$.

A segunda distinção normalmente efetuada pela doutrina é quanto à prova, propriamente dita, aos meios de provas ${ }^{190}$ e ao conteúdo de prova ${ }^{191}$.

Como se disse, enquanto a prova é, sinteticamente, a evidência insofismável do fato, os meios de provas são os métodos de análise que viabilizam a realização e valoração da prova (v.g., a prova pericial) ${ }^{192}$, ou seja, “os instrumentos pelos quais procura-se demonstrar

\begin{abstract}
${ }^{189}$ Sobre a distinção de fonte de prova, meio de prova e meios de investigação ver GOMES FILHO, Antonio Magalhães. Notas sobre a terminologia da prova (reflexos no processo penal brasileiro), in Estudos em homenagem a professora Ada Pellegrini Grinover, p. 308. "Distingue-se ainda, na terminologia processual, as expressões fonte de prova, meios de prova e meios de investigação da prova. Fala-se em fonte de prova para designar as pessoas ou coisas das quais pode-se conseguir a prova (rectuis, o elemento da prova), resultando disso a sua usual classificação em fontes pessoais (testemunhas, vítima, acusado e peritos) e fontes reais (documentos, em sentido amplo).Outra coisa são denominado os meios de prova, ou seja, os instrumentos ou atividades por intermédio dos quais os dados probatórios (elementos de prova) são introduzidos e fixados no processo (produção da prova). São, em síntese, os canais de informação de que se serve o juiz. Assim, quando se fala em prova por testemunhos ou prova documental, indica-se que a representação do fato foi conseguida por meio do testemunho ou do documento. Essas atividades são reguladas nos códigos de processuais, de modo a ordená-las com o objetivo de propiciar uma seleção mais criteriosa das informações, especialmente pela concomitante participação do juiz e das partes nessa tarefa, assim como assegurar a idoneidade dos dados obtidos. (...) Outra importante distinção, ressaltada por Paolo Tonini, reside na surpresa que quase sempre acompanha a realização dos procedimentos de investigação, sem a qual seria inviável a obtenção das fontes de prova, ao passo que nos meios de prova é rigorosa a obediência ao contraditório, o que supõe tanto o conhecimento como a efetiva participação das partes na sua realização".
\end{abstract}

${ }^{190}$ O diploma processual vigente não diferencia meios de prova dos meios de obtenção de prova, entretanto o projeto de Código de Processo Penal Brasileiro traz esta distinção. Aproximando-se, portanto, de outros diplomas processuais penais que já traziam no texto legal a diferença entre meios de prova e meios de obtenção de prova, como o da Itália e o de Portugal.

${ }^{191}$ Cf. WAMBIER, Luiz Rodrigues. Curso Avançado de Processo Civil, p. 407. Segundo o autor, "Meios de prova são as diversas modalidades pelas quais a constatação sobre a ocorrência ou inocorrência dos fatos chega ao juiz. Podem ser diretos (inspeção judicial, fatos notórios) ou indiretos (documentos, testemunhas). Conteúdo da prova é o resultado que o meio produz, ou seja, o convencimento que o juiz passa a ter da ocorrência ou inocorrência dos fatos, porque a eles foram levados (e revelados) por determinado meio de prova. A distinção é necessária e importante. Há casos em que o Código de Processo Civil desautoriza certos meios (por exemplo, não se admite prova exclusivamente testemunhal nos casos envolvendo contratos cujo valor exceda o décuplo do salário mínimo - art. 401 -, bem assim a prova pericial quando o fato independe de conhecimento técnico ou científico - art. 420, parágrafo único, I), independentemente do conteúdo. Aliás, nesses casos, apesar de determinado meio ser vedado (nos exemplos dados, prova testemunhal e prova pericial, respectivamente) pode o fato obviamente ser conhecido por outro meio (documentos, por exemplo).

${ }^{192}$ Ver. FERNANDES, Antonio Scarance. "Tipicidade e sucedâneos da prova”, in Provas no processo penal. Estudo comparado, p. 16/30. "as características da tipicidade ou atipicidade da prova decorrerão de cinco situações possíveis: a) o meio de obtenção ou de produção de prova está previsto e é regulado mediante procedimento próprio; b) o meio de obtenção ou de produção de prova está previsto, não está regulado, mas há emissão ao procedimento a ser seguido; c) o meio de obtenção ou de produção de prova está previsto, não está regulado e não há remissão a nenhum procedimento a ser seguido; d) o meio de obtenção ou de produção de prova é apenso referido nominalmente, sem qualquer regulamentação ou remissão ao procedimento a ser seguido; e) o meio de obtenção ou de produção de prova não é sequer referido. Serão típicos os meios de obtenção ou de produção de prova quando ocorrentes as situações descritas nas letras a), b), e atípicos quando 
determinado fato" ${ }^{\prime 193}$. Por sua vez, o conteúdo da prova é o resultado da prova e sua relevância sobre o direito ${ }^{194}$.

Além dessas distinções, cumpre ainda diferenciar os meios de prova dos meios de obtenção de provas ou de investigação.

Segundo Scarance Fernandes:

"O campo dos meios de pesquisa ou de obtenção de prova é amplo, podendo-se, a grosso modo, englobá-lo em quatro grupos: a) os exames, as vistorias, as revistas; b) as buscas, apreensões, os sequestros; c) as interceptações, as escutas; as quebras de sigilo; c) as ações encobertas, a infiltração policial.

Esse meios de obtenção de prova distinguem-se dos meios de produção de prova e constituem normalmente providências de natureza cautelar. Critica-se na Argentina, a classificação como meios de prova de atividades como a revista, a busca, o seqüestro, pois seriam medidas assecuratórias ou conservativas. Também no Brasil, afirma-se que a busca e apreensão não é meio prova, mas uma medida cautelar, e se ressalta que a interceptação telefônica é medida cautelar"195.

Cabe, ainda, tecer algumas considerações quanto ao conceito de indício ${ }^{196}$, figura espectral adotada em nosso ordenamento jurídico que, nos dizeres de Moura ${ }^{197}$, constitui

configuradas as situações das letras c), d) e e). Como se vê, a análise da tipicidade ou atipicidade depende das disciplinas dadas aos meios de provas pelos ordenamentos jurídicos".

${ }^{193}$ MELLO, Rodrigo Pereira de. Provas ilícitas e sua interpretação constitucional, Porto Alegre: 2000, p. 62.

${ }^{194}$ WAMBIER Luiz Rodrigues. "Curso Avançado de Processo Civil, p. 407.

${ }^{195}$ FERNANDES, Antonio Scarance. "Prova e sucedâneos da prova no processo penal (Extraído do relatório para a XX Jornadas Ibero americanas de direito processual penal em Málaga, Espanha 2006)", in Revista Brasileira de Ciências Criminais, São Paulo: RT, nº 66, maio/junho de 2007, p.195.

${ }^{196}$ Há quem entenda que o indício é uma das espécies da prova indireta, sendo a outra presunção. Ver. MALATESTA, Nicola Framarino Dei, A lógica das provas em matéria criminal, Alexandre Augusto Correia (trad.), vol. I, São Paulo: Saraiva, 1960, p. 216.

${ }^{197}$ MOURA, Maria Tereza de Assis. A Prova por Indícios no Processo Penal, São Paulo: Saraiva, p. 43. 
"respeitável meio de prova, o indício merecia ter recebido melhor atenção do legislador, mormente no que concerne aos requisitos para sua valoração".

Não obstante tal posicionamento, Grinover ${ }^{198}$ entende ser o indício fonte de prova indireta por uma operação lógica (a presunção hominis) e não, meio de prova, apesar de se encontrar disciplinado no capítulo de prova.

Conforme dispõe o art. 239 do Código de Processo Penal: "Considera-se indício a circunstância conhecida e provada, que, tendo relação com o fato, autorize, por indução, concluir-se a existência de outras circunstâncias".

A ideia de indício é a depreensão que se pode fazer à luz de um fato comprovado. Por exemplo, se há prova da existência de resíduo de pólvora na mão de um suspeito, pode-se depreender que ele disparou uma arma de fogo.

Depreender algo, por sua vez, remete à aparente possibilidade de que se pode provar algo unicamente pelo método indutivo, o que é inadmissível ${ }^{199}$. De fato, o próprio citado art. 239 do CPP utiliza o termo indução.

Com a habitual veemência, Malatesta ${ }^{200}$ questiona:

"Mas qual é a força substancial e probatória do indício? A medida desta força probatória só pode encontrar-se na natureza íntima da prova que examinamos; natureza íntima que determinamos numa relação específica de causalidade. É necessário, por isso, para conhecer a força probatória do indicio, investigar em particular a força da relação específica de causalidade que nele lhe liga o desconhecido ao conhecido."

\footnotetext{
${ }^{198}$ GRINOVER, Ada Pellegrini, FERnANDES, AntonioScaranse e GoMES FILHO, Antonio Magalhães. As nulidades no processo penal, $8^{\mathrm{a}}$ ed., São Paulo: RT, 2004, p. 195.

199 Não é nosso escopo analisar os modelos de justificação utilizados na motivação das decisões: indutivo, dedutivo e retórico. Para melhor compreensão sobre estes modelos ver GoMES FILHO, Antonio Magalhães, $A$ Motivação das Decisões Judiciais, São Paulo: RT 2001, p. 119 e seguintes.

${ }^{200}$ MALATESTA, Nicola Framarino dei. A Lógica das Provas em Matéria Criminal, p. 220.
} 
Vale dizer, o indício não basta por si só como prova ${ }^{201}$ (ele apenas fundamenta-se em uma base fática comprovada), presta-se apenas para aferir a circunstância do fato em relação à prova plena ${ }^{202}$.

Como assentado por Pitombo ${ }^{203}$ :

“[...] o indício se presta a indicar a autoria, jamais servirá para comprovar o corpo do delito. Ele pode lastrear a acusação, porém, de modo isolado, nunca poderá dar suporte à sentença. Assim, reconhecendo-se o valor probante dos indícios, se e quando observada a estrita legalidade subsidiar, de modo fundamentado, o livre convencimento do juiz, é preciso afastar qualquer vinculação ou equiparação do indício como presunção."

\subsection{Correlação da prova e busca da verdade atingível}

Feitas essas considerações, mister se faz verificar a relação existente entre prova e busca da verdade atingível ${ }^{204}$ no processo penal.

\footnotetext{
${ }^{201}$ ASSIS MOURA, Maria Tereza de Assis. A Prova por Indícios no Processo Penal, op. cit., p. 98 "Posto que os indícios se pesam, e não se contam, não basta que apareçam provados em números plural; é indispensável que, examinados em conjunto, produzam a certeza moral sobre o fato investigado. Para tanto, devem ser graves, precisos, e concorrerem, harmonicamente, a indicar o mesmo fato. O concurso dos indícios deve ser completo em todos os sentidos, para construir uma prova sólida. Assim, se um indício sério resta em desacordo com o conjunto, é necessário procurar a causa; se a discórdia persiste, é uma falha que pode comprometer a sua eficácia probante. Da mesma forma, se os indícios são leves ou de pouco valor probatório, porque a relação de causalidade com o fato indicado não é clara nem precisa, de seu conjunto tampouco poderá resultar a certeza processual necessária para que o juiz baseie neles sua decisão”.

${ }^{202}$ TONINI, Paolo. A Prova no Processo Penal Italiano, p. 58: “O indício é idôneo para apurar a existência de um fato histórico delituoso somente quando presentes outras provas que excluam uma diversa reconstrução do acontecimento. O princípio é formulado no art. 192, inciso 2, do CPP: a existência de um fato não pode ser deduzida por meio de indícios, a menos que estes sejam graves, precisos e consonantes. Desta regra emerge, em primeiro lugar, que um único indício nunca é suficiente."

${ }^{203}$ PITOMBO, Cleunice Valentim Bastos, Força probante dos indícios e sentença condenatória, in Boletim do IBCCRIM, ano 21 n. $^{\circ} 242$, janeiro/2013

${ }^{204}$ Diz-se verdade atingível posto ser impossível a reconstituição dos fatos exatamente como se deram de forma a propiciar uma certeza absoluta. Nos dizeres de MITTERMAIER, C. A. J. Tratado da prova em matéria criminal ou exposição comparada, p. 66. "Porém, a despeito desta possível combinação, não ficarão espírito menos satisfeito, quando motivos suficientes sustentarem a certeza, quando todas as hipóteses razoáveis tiverem sido figuradas e rejeitadas após maduro exame; então o juiz julgar-se-á, com segurança na posse da verdade, objeto
} 
Como se procurou sustentar anteriormente, o objetivo da prova é viabilizar o absoluto conhecimento, pelo juiz da causa, dos fatos que norteiam a demanda colocada para sua apreciação e, sobre ela, possa o julgador pronunciar-se e estabelecer a consequência jurídica decorrente.

Segundo Carnelutti ${ }^{205}$, “as provas servem, exatamente, pra voltar atrás, ou seja, para fazer, ou melhor, para reconstituir uma história”.

Nesse sentido, a prova afigura-se, como preleciona Neves Baptista ${ }^{206}$ :

“[...] "umbilicalmente atada às idéias de conhecimento e de verdade. Seja como 'confrontação da versão de cada parte com os elementos ou meios produzidos para afiançá-las' seja como 'confrontação da versão de cada parte com os elementos ou meios produzidos para afiançá-la', seja como demonstração de 'qualquer matéria de fato cuja veracidade é submetida à investigação policial', o termo designativo da idéia associa-se, invariavelmente, à percepção e compreensão de algo, que se afirma ou nega".

A prova - ou sua inexistência - reverbera não só em face do acusado, mas por toda a sociedade, extrapolando o âmbito do processo.

Nesse sentir observa Gomes Filho que "de fato, mais do que em qualquer outro procedimento cognitivo, sobressai no probatório judicial o seu caráter social, visto que sua finalidade não está limitada à formação do convencimento do juiz, mas visa

único de suas indagações; e é, sem dúvida, essa certeza da razão, que o legislador quis que se fosse a base para o julgamento. Exigir mais seria querer o impossível; porque em todos, os fatos que dependem do domínio da verdade histórica jamais se deixa atingir pela verdade absoluta”. COMOGLIO, Luigi Paolo et al. Le prove civili, p. 72: assevera que "laverità, nel processo o al difuori, à sempre uma e, como tale, resta pur sempre conoscibile, entro i limitipropridel contesto in cuila si invoca". E MALATESTA, Nicola Framarino dei, A lógica das provas em matéria criminal, p. 45, preleciona que "considerando que a certeza do ponto de vista objetivo, considerando-a do ponto de vista da sua correspondência à verdade, conclui-se que certeza verdadeira é aquela que corresponde absolutamente sem possibilidade de erro, à verdade objetiva; e uma vez que esta a certeza absoluta não é de se esperar em matéria criminal, também se deduz ainda que certeza criminal não é senão probabilidade, pois há sempre possibilidade de erro".

${ }^{205}$ CARNELUTTI, Francesco. As misérias do processo penal, p. 44.

${ }^{206}$ NEVES BATISTA, Francisco das. O mito da verdade real na dogmática do processo penal, p. 41. 
preponderantemente à obtenção do consenso do grupo em nome do qual será pronunciada a decisão" ${ }^{207}$.

Considerada a magnitude da importância do elemento probatório, seu aspecto se sobressai quando avaliado no contexto processual penal: A prova é, em última análise, o elemento que revela - ou deve revelar - a verdade verificável ${ }^{208}$ dos fatos.

Em outras palavras, a produção de provas está intimamente relacionada - no campo judicial - à ideia de cognição exauriente no processo, sendo preocupantes certas tendências contemporâneas que procuram relativizar princípio tão elementar de direito.

Fundamental se faz assentar que o processo penal admite, na busca da almejada verdade, todos os meios lícitos de prova, com participação das partes (que deve ser ampla) e do próprio juiz, que não deve se quedar inerte. Possui o juiz poder-dever inquisitivo, calcado em um sistema de estrita cooperação para o deslinde da causa penal, de modo a ressaltar não só as razões da acusação, mas também as da defesa. ${ }^{209}$

Esse poder inquisitivo do juiz, entretanto, conforme ensinamento de Pitombo, “jamais aflora ilimitado, o objeto controlado já o demarca e, ainda, não há como acossar, sem constrangimento ilegal, a verdade material, se esgotados, conforme a razão, os meios lícitos de seu apuramento ${ }^{, 210}$.

No perfil constitucional, o juiz é chamado a desempenhar o papel de garantidor dos direitos fundamentais, destarte, qualquer invasão em tais direitos só pode ocorrer com

\footnotetext{
${ }^{207}$ GOMES FILHO, Antonio Magalhães. Direito à Prova no Processo Penal, p. 17.

${ }^{208}$ Ver BADARÓ, Gustavo Henrique RighiIvahy. Ônus da Prova no Processo Penal, p. 31. "o fato de existirem regras jurídicas sobre a prova não é suficiente para diversificar, do ponto de vista epistemológico, a verdade que se pode alcançar por meio da instrução processual, da verdade obtida fora do processo. $O$ que existe são limites distintos para a obtenção da verdade, o que não quer dizer que, do ponto de vista da teoria do conhecimento, haja 'verdades' distintas. Certamente, nenhuma delas será uma verdade absoluta. A distinção está apenas no grau de limitação à descoberta da verdade. A verdade acertada pelo juiz jamais será uma verdade absoluta. Partindo de tal premissa, não tem sentido procurar distinguir a denominada verdade formal que se aplicaria ao processo civil - daquela outra que, em contraposição, costuma-se chamar de verdade material-que seria buscada no processo penal".

${ }^{209}$ TUCCI, Rogério Lauria, et alli. Princípio e regras orientadoras do novo processo penal brasileiro.

${ }^{210}$ PITOMBO, Sérgio Marcos de Moraes. O juiz penal e a Pesquisa da Verdade Material, in Processo Penal e Constituição Federal, p. 74. Mesmo após a reforma do diploma processual, com o advento da lei 11690/08, este cenário não se modificou, basta ver o que dispõe o artigo 156 do Código de Processo Penal Brasileiro, que permite ao juiz ordenar a produção antecipada de provas, mesmo antes de se iniciar o processo (conferindo ao juiz maior poder que o antigo dispositivo permitia).
} 
autorização judicial, devidamente fundamentada, em consonância com as hipóteses legais e constitucionais $^{211}$.

Lembrando os ensinamentos de $\operatorname{Rothwax}^{212}$, ao analisar o processo penal norte americano, a busca da verdade não é a única tarefa do processo penal:

"Mesmo se há evidência de que um acusado cometeu crime, o Estado não pode violar seus direitos no processo de acusá-lo. Vivemos numa democracia, não num Estado policial. E ainda quando um acusado tenha mostrado em numerosas ocasiões passadas que não é avesso a flanquear a lei e pôr em perigo seus concidadãos, continuará tendo os mesmos direitos de qualquer cidadão [...]. O inteiro propósito de nossa Declaração de Direitos é restringir o poder governamental e, idealmente, fazê-lo operar efetivamente, sem opressão ou abuso. Assim, limitamos a verdade no interesse da justiça e do controle."

Existem limites legais e constitucionais à busca da verdade atingível, sendo ilícito permitir "o uso de métodos que violam a dignidade da pessoa do acusado ou do ofendido, através de meios físicos, químicos, mecânicos, ou de qualquer natureza outra."213

Não se há de olvidar que o processo penal exibe caráter publicístico, tendo em vista que ambos os interesses por ele tutelados (jus puniendi e juslibertatis) possuem alta relevância social.

Destarte, o processo penal de cunho garantista ${ }^{214}$ impõe limites ao poder estatal quando da aplicação da norma, buscando a salvaguarda dos direitos individuais e

\footnotetext{
${ }^{211}$ CHOUKR, Fauzi Hassan. Processo Penal à luz da constituição, p. 29.

${ }^{212}$ Tradução livre. TOTHWAX, Harold J. Guilty. The collapse of criminal justice, p. 32.

${ }^{213}$ CHIMENTI, Francesco. O processo penal e verdade material: teoria da prova, p. 87.

${ }^{214}$ Ver FERRAJOLI, Luigi. Garantismo. Uma discusión sobre derechoyu democracia e, do mesmo autor Direito e Razão. Teoria do Garantismo Penal, p. 73/4. Para Ferrajoli, existem dez termos condicionantes a atribuição de pena: "delito, lei, necessidade, ofensa, ação, culpabilidade, juízo, acusação, prova e defesa”. Continua o autor, quando aos axiomas garantistas "não expressam proposições assertivas, mas proposições prescritivas; não descrevem o que ocorre, mas prescrevem o que deva ocorrer (...) não se trata de uma condição suficiente, na presença da qual esteja permitido ou obrigatório punir, mas sim de uma condição necessária, na ausência da qual não está permitido ou está proibido punir".
} 
fundamentais, universalmente consagrados. A verdade judicial deve ser entendida como aquela que o juiz busca nas provas dos autos.

Esses limites que se impõem na persecução penal estão intimamente relacionados à atividade probatória, repercutindo na produção, na validade, na nulidade e na própria licitude da prova.

Note-se que o direito à prova possui amplo espectro, de acordo com Scarance Fernandes. $^{215}$

"[...] se manifesta através processualmente através de vários direitos da parte: a) direito de requerer a produção de prova; b) direito a que o juiz decida sobre o pedido de produção de prova; c) direito a que, deferida a prova, esta seja realizada, tornando-se todas as providências necessárias para sua produção; d) direito de participar na produção da prova; e) direito a que a produção da prova seja feita em contraditório; f) direito a que a prova seja produzida com a participação do juiz; g) direito a que, realizada a prova, possa manifestar-se a seu respeito; e) direito a que a prova seja objeto de avaliação pelo julgador.”

Nesse sentir, "não se pode mais conceber, em homenagem ao princípio da verdade atingível, que a busca incontrolada da prova possa, sem motivos ponderáveis e sem observância de um critério de proporcionalidade, ofender a intimidade" ${ }^{216}$, ou quaisquer outros direitos e garantias ínsitos ao justo processo. ${ }^{217}$

\footnotetext{
${ }^{215}$ FERNANDES, Antonio Scarance. Processo Penal Constitucional, 2a ed., São Paulo: RT, 2000, p. 68/9.

${ }^{216}$ FERNANDES, Antonio Scarance. Processo Penal Constitucional, 2a ed., São Paulo: RT, 2000, p. 78.

217 Ver GRINOVER, Ada Pellegrini, FERNANDES, Antonio Scarance, GOMES FILHO, Antonio Magalhães. as nulidades no processo penal, p. 22. "Da idéia individualista das garantias constitucionais processuais, na ótica exclusiva de direitos subjetivos das partes, passou-se em épocas mais recentes ao enfoque das garantias do 'devido processo legal ' como sendo qualidade do próprio processo, objetivamente considerado, e fator legitimante do exercício da função jurisdicional. Contraditório, ampla defesa, juiz natural, motivação, publicidade etc. constituem é certo, direitos subjetivos das partes, mas são, antes de mais nada, características de um processo justo e legal, conduzido em observância ao devido processo, não só em benefício das partes, mas como garantia do correto exercício da função jurisdicional. Isso representa um direito de todo o corpo social,
} 
Para que seja considerada válida, a prova deve ser produzida mediante o devido processo legal, devendo representar uma "realidade em todo o desenrolar do processo judicial, de sorte que ninguém seja privado de seus direitos, a não ser que no procedimento em que este se materializa se verificarem todas as formalidades e exigências em lei prevista." 218

Neste diapasão vale lembrar os ensinamentos de Desprez ${ }^{219}$ :

“[...] a verdade ([...] deve ser conquistada na forma de um debate que pertence a um rito que assegura a regularidade' $\mathrm{O}$ coração do processo reside no debate contraditório. Este último permite a passagem de um conflito a contestação e constitui um instante indispensável a emergência da verdade e a restauração da garantia social; ele exprime a própria essência da justiça no desenrolar do processo . Este debate contraditório deve ser publico e se desenrolar diante de um tribunal imparcial, e supõe que cada elemento de prova possa ser discutido livremente pelas partes; o contraditório é intimamente ligado a oralidade dos debates. O debate contraditório é essencial a todas as formas de processo, mas além disso, o processo penal moderno deve privilegiar o princípio do contraditório que constitui uma garantia fundamental para uma boa administração a justiça."

A busca da verdade atingível - que traduz um valor, que legitima a atividade jurisdicional penal ${ }^{220}$ - é limitada pela exigência de respeito ao justo processo (fair trial $^{221}$ ),

interessa ao próprio processo para além das expectativas das partes e é condição inafastável para uma resposta jurisdicional imparcial, legal e justa".

${ }^{218}$ Ver TUCCI, Rogério Lauria e TUCCI, José Rogério Cruz. Constituição de 1988 e processo, p. 16.

${ }^{219}$ Tradução livre. DESPREZ, François. Rituel Judiciare et Procès penal, Paris: L.G.D.J, 2009, p. 146. “"La vérité (...) doit se conquerirdontleriteassure par larégularité'. Le coeurduprocès reside dansledébatcontradictoire. Cedenierpermentlepassageduconflit à laconstestation $e$ constituel'instantindispensable à l'émergence de lavérité et a larestaurationdulien social; il exprime l'essencemême de la justice dansledéroulementduprocès. Cedébatcontradictoiredoitêtrepublic et se déroulerdevant um tribunal impartial, ilsuppose que chaqueélément de preuvepuisseêtre discute libremente par lesparties; lecontradictoire est intimementlié à l'oralitédesdébats. Le débatcontradictoire est essentiel à tout ele forme de procès, mais de surcrô̂t, laprocédurepenalemodernedoitprivilégierle príncipe ducontradictoirequiconstitue une garantiefondamentalepour une bonneadminsitration de la justice. Lors de l'audience, leritueljudiciaire est essentiel à l'émergencedudébatcontadictoire”.

${ }^{220}$ GOMES FILHO, Antonio Magalhães. Direito à prova no processo penal, p. 54. 
que constitui um dos vetores presentes no rol de direitos humanos consagrados internacionalmente, sendo certo que o direito à prova é colorário do giusto processo.

Nesse sentir, ao mesmo tempo em que se deve garantir a liberdade na produção de provas, os meios de obtenção de prova e de prova devem ser idôneos e juridicamente admissíveis $^{222}$.

Essas questões são de extrema importância na cooperação jurídica internacional em matéria penal, podendo constituir - diante da diversidade de sistemas processuais existentes no mundo, cujas opções internas valorizam princípios em graus divergentes - o calcanhar de Aquiles da introdução em nosso sistema jurídico das provas produzidas por meio da cooperação penal ${ }^{223}$.

Afinal, se é verdade que na cooperação jurídica internacional em matéria penal as provas requeridas devem ser efetuadas de acordo com o direito do país requerido, também é verdade que sua inserção no processo penal nacional deve respeitar, pela própria segurança jurídica, limites quanto à admissibilidade da prova.

\footnotetext{
${ }^{221}$ SUANNES, Adauto. Os fundamentos éticos do devido processo legal, p. 133. "A noção mais elementar de fair trail, de processo (ou, mais adequadamente, julgamento) justo, aplicado à atuação do juiz criminal, implica na idéia de que uma condenação somente pode sobrevir após ter sido dada ao acusado a oportunidade de ser ouvido e de apresentar sua versão dos fatos. Mais: que na instrução do feito sejam observados certos cuidados que dizem com a dignidade do ser humano. É esse o fundamento ético".
}

${ }^{222}$ GOMES FILHO, Antonio Magalhães. Direito à prova no processo penal, p. 95. "A admissibilidade da prova constitui, portanto, um conceito de direito processual e consiste numa valoração prévia feita pelo legislador, destinada a evitar que elementos provenientes de fontes espúrias, ou meios de prova reputados inidôneos, tenham ingresso no processo e sejam considerados pelo juiz na reconstrução dos fatos; daí sua habitual formulação em termos negativos: inadmissibilidade, proibição de prova, 'exclusionaryrules'.

${ }^{223}$ Ver, FERRAJOLI, Luigi. Direito e Razão. Teoria do Garantismo Penal, p. 61/2. "Mas ainda hoje, no atual processo informado pelo principio da 'livre apreciação do juiz', continuamos disciplinando pelo menos o método de investigação e de formação da verdade processual. Pense-se, em nosso ordenamento, nos termos precluso (art. 173 do novo Código de Processo Penal), nas formas e condições de admissão de prova e na nulidades dos atos processuais por vícios formais (arts. 177-186), nos testemunhos inadmissíveis (arts. 196 e 197), na inutilidade das prova ilegitimamente adquiridas (arts. 191 e 526), nas exclusões interpostas nas investigações em face do segredo de Estado ou por outras modalidades de sigilo (arts. 200-203), na redução protestativa das lista de testemunhas por parte do juiz (art. 468, inciso 2). Pense-se, por outro lado, nas regras jurídicas expressamente epistemológicas, como as normas sobre as modalidades das investigações instrutórias, sobre a interpretação da lei penal e sobre a proibição de analogia, a presunção de não-culpabilidade até prova em contrário, o ônus da prova atribuído à acusação, o princípio do in dubio pro reo e a presunção legal de verdade das teses contidas em sentenças transitadas em julgado. Por causa destas regras, a relação já mencionada entre verdade e validade, sobre a qual voltarei amplamente no parágrafo 37 , resulta complicada: não é só a verdade que condiciona a validade, mas é também a validade que condiciona a verdade normativa, no tríplice sentido: a) um vez comprovada definitivamente, tem valor normativo; b) está convalidada por normas; c) é verdade na medida em que seja buscada e conseguida mediante o respeito às normas". 
Isso, entretanto, não significa nem pode significar a negativa de cooperação. Tão somente reforça a necessidade de harmonização ${ }^{224}$ das normas entre os diversos países de modo a tornar efetiva a cooperação jurídica internacional, permitindo-se, assim, o mútuo reconhecimento em matéria de prova penal. Destarte, pode-se dizer que a admissibilidade da prova constitui o ponto de partida para a solução de tais questões. ${ }^{225}$

Em uma sociedade vítima de criminalidade globalizada, é preciso, sempre, ter em mente que:

“[...] a gravidade do crime em investigação ou em julgamento não pode autorizar a adoção de meios repressivos que repugnam a consciência de país democrático, violando a dignidade da pessoa humana, reduzindo o valor da liberdade e igualdade, e levando o

\begin{abstract}
${ }^{224}$ Como adverte AMODIO, Ennio. in archivio.rivistaaic.it/material/convegni/roma/20021114/amodio.html., analisando o sistema europeu, "La ricercadi uma armonizzazione, certamente fondamentale per lacreazionedilegamipiù stretti in sede euorpea, non deve transformarsinellaattualzioneforzatadi um modelo processualecomune. I comparatistdiconoche, oltre ala armonizzazine, cè um altro valore chevasalvaguardato: quellodellabeautyofdiversity. La bellezzadelladiversitàciinsegnache à sbagilatopuntaresu um processo penaleeuropeodestnato ad operare in tutti gliStatiallostesso modo. L'esperienza de altriPaesiciinsegna, invece, ad impostare $i$ nostristudi in uma chiavemenoforamlistica de quellafin que seguita. Per conoscerelarealtàeffettivadel processo è necessária avvalersi, in primo luogo, di uma intergrazioneorizzontale, intesa come saldatura dei problemi processual a quellidiorinamentogiudiziario, in secondoluogo, di uma intergrazioneverticale, prótese a cogliereleinveitabilidivergenzetra norma e prassi, così da ragionareavendo bem chiaroildirittoprecossuale vivente. Esiste uma procedurapenaleinvisibileche non si puòleggereneimanualienirepertorigiurisprudenziali, ma si tocca com mano nellaeffettivitàdella pratica giudiziaria. Libertàpersonaledell'imputato, cronacagiudiziaria e maxiprocessi, per fare qualcheesempio, sono arree in cuileprassidevaintefanno viverei l processo penal com metodi e cadenzescanaosciutiallenorme. L'orizzontedinostristudi non puòremanerecircoscrito al piano normativeperché, descrito in questitermini, il direito à 'come uma câmera incantata, pietrificata, immobile, senza tempo in virtùdi uno stranoincatesimo' (Friedman)".
\end{abstract}

225 Analisando direito à prova na Comunidade Européia: ILLUMINATI, Giuilo. Responsabiledell'unitàdiricerca, in www.ricercaitaliana.it/prin/unita_op-2005122029_htm. "Il presente progettodiricerca si proponedirealizzare uno studiosull'armonizzazione dele regolédiammisssione e de esclusionedella prova dichiarativa in âmbito comunitario. (...) Nell'otticadi uno studiosull'armonizzazionedella disciplina della prova dichiarativa, al binômio ammissionelesclusionedella prova deve esserericonsociuto um ruoloprincipale. (...) Di pari rilevanzaapparelostudio dei divietiprobatori, aspettofondamentalediogni sistema processualepenaleperché índice deltassodilegalitàdell'ordinamento.(...) Dáltronde, nonostantelediversetradizionigiuridiche, à comunqueosservabile a livellocontinentaleun progressiva contaminazionefra i diversisistemi, contaminazioneche si deve soprattuttoall'operaarmonizzatricecondottradalla Corte eutopea dei dirittiumani. Il case lawdella Corte diStrausburgoèquindi fonte preziosa per l'indagesulleregoleprobatoriecomuni: sebbenela questione vengaaffrontatadal solo ponto divistadelrispetto dele granziedell'imputato, piú volte lecixicioniresecontengonoindicazionidi amplo respiro sull'ammissibilitàdella prova e già in passatolagiursiprudenzadella Corte europea há imposto ai legislatorinazionallimodifichelegislativedirette a rendereconforigliordinamentiinterni com legaranzieconvenzionali. L'analisidellagiurisprudenzadella Corte diStrausburgo assume poi um' importanza ancora maggiore in segutioall'adesione ala Convenzioneeutopeaed ala relativa atribuzionealleregoleconvenzionalidell'efficaciadiregolecomunitarie (art. I-9 Cost. eur.)”. 
Estado à imoral competição com os criminosos na prática da violência, em atos de desumanidade." 226

Afinal, persecução penal e a punição dos culpados, não constituem valores absolutos no processo penal.

A investigação e a luta contra a criminalidade devem ser conduzidas, no entender de Grinover ${ }^{227}$

“[...] de uma certa maneira, de acordo com um rito determinado, na observância de regras preestabelecidas. A dignidade e a moralidade do instrumento utilizado constituem, de per si, um valor e se colocam consequentemente como limite ao poder estatal. Se a finalidade do processo não é a de aplicar a pena ao réu de qualquer modo."

\subsection{Direito à prova e ao justo processo consagrado no âmbito internacional.}

Feitas estas considerações, passa-se à análise do direito à prova - que integra o quadro de mínimas garantias ínsitas ao processo penal justo, assegurado pela Convenção Americana de Direitos do Homem (São José da Costa Rica, 1969) ${ }^{228}$ e pela Convenção

\footnotetext{
${ }^{226}$ Ver RAILDA, Saraiva. A constituição de 1988 e o ordenamento jurídico-penal brasileiro, p. 69.

${ }^{227}$ GRINOVER, Ada Pellegrini. Liberdades públicas e processo penal- as interceptações telefônicas, p.58.

${ }^{228}$ Prevê em seu art. $8^{\circ}, 2, f$ que: “...Durante o processo, toda a pessoa tem direito, em plena igualdade, às seguintes garantias. f) direito da defesa de inquirir as testemunhas presentes no tribunal e de obter o comparecimento , como testemunhas ou peritos, de outras pessoas que possam lançar luz sobre os fatos". Ver FigueIREDo StEINER, Sylvia Helena de. A Convenção Americana sobre Direitos Humanos e sua Interpretação ao Processo Penal Brasileiro, p. 50. "A convenção Americana sobre Direitos Humanos, que teve como modelo a Convenção Européia, foi aprovada em 1969, na Conferência Especializada sobre Direitos Humanos realizada em São José da Costa Rica. Daí ser mais conhecida como Pacto de San José da Costa Rica. Com um elenco maior de previsões do que as Convenções anteriores, incorpora também disposições expressas da Declaração Americana e do Pacto de Direitos Civis e Políticos. Entrou em vigor em 1978, após o depósito da ratificação pelo décimo primeiro Estado Americano. Como afirmam Buerghental, Norris e Shelton, o número de direitos que a Convenção Americana proclama é maior que a Convenção Européia, e muitas das disposições estabelecem garantias mais avançadas e abrangentes do que aquela ou o Pacto de Direitos Civis e Políticos. Ainda assim, foi ratificada praticamente por todos os estados americanos com um número mínimo de reservas . Estabelece, ainda, dois órgãos para assegurar seu cumprimento efetivo: a Comissão Interamericana de Direitos Humanos e a Corte Interamericana de Direitos Humanos.
} 
Europeia de Direitos Humanos (Estatuto de Roma, 1950 229 ), Pacto Internacional de Direitos Civil e Políticos (aprovado pela Assembleia Geral da ONU em 1966 ${ }^{230}$ ) - e de sua admissibilidade.

Não se há de negar que houve, pelo menos no mundo Ocidental, o fenômeno de constitucionalização do Justo Processo ${ }^{231}$, pelo qual se incorporaram, aos sistemas pátrios, direitos e garantias individuais ínsitos ao processo penal, assegurados pelos direitos humanos, como a imparcialidade do juiz, a paridade de armas, a duração razoável do processo, dentre outros $^{232}$.

\begin{abstract}
${ }^{229}$ Prevê a possibilidade de a defesa participar na produção de provas (art. $6,{ }^{\circ} \S 3^{\circ}$, d). "Todos aqueles contra quem pesa uma acusação criminal têm os seguintes direitos: $d$ ) inquirir ou fazer inquirir a testemunha de acusação e obter o comparecimento e inquirir a testemunha nas mesmas condições que a acusação". Ver MaLAn, Diogo Rudge. Direito ao confronto no processo penal, p. 116. "Para efeito de incidência do right of confrontation, o conceito de testemunha adotado pela Corte Europeia não se restringe as pessoas que comparecem em juízo para depor, abarcando também quem presta declarações na fase da investigação preliminar (caso Ash vs. Áustria, Isgrò vs. Itália e Kstovski vs. Paises Baixos)”. Para ter acesso as decisões da Corte consultar www.echr.coe.int/echr
\end{abstract}

${ }^{230}$ Estabelece em seu art. $14, \S 3^{\circ}$, que "Na determinação de qualquer acusação criminal, todos devem ser investidos das seguintes garantias mínimas, em grau de igualdade: e) inquiri, ou fazer inquirir, a testemunha de acusação e obter comparecimento e inquirir a testemunha, nas mesmas condições que a acusação".

231 Ver TAVARES, André Ramos. Curso de Direito Constitucional, p. 404/6. "Os autores da Declaração Universal de 1948 foram fortemente influenciados pelos direitos fundamentais positivados em diversos ordenamentos nacionais, especialmente o norte-americano e o francês. Uma vez que o catálogo de direitos humanos passou a ser cristalizado no âmbito internacional, foi a vez de as constituições nacionais receberem sua inspiração, como ocorreu com a Lei Fundamental de Bonn. Atualmente, mais de 3/4 das Constituições mundiais foram promulgados após 1969, com o que fica clara a influência mundial que o documento em questão apresente. De outra parte, no âmbito nacional se desenvolvem direitos novos, que se irradiam. Ex.: Proteção de dados, Direito Ambiental, Direto das Comunicações, genoma. Alguns Estados chegaram ao ponto máximo de relação com os direitos humanos, pois constitucionalizaram diretamente os textos internacionais sobre direitos humanos no lugar de seu catálogo de direitos fundamentais ao seu lado, como a Áustria e o Peru. É cada vez mais frequente os Estados que interpretam seus direitos à luz das declarações universais. EX.: Canadá, quanto à Convenção europeia, com base em certos paralelismos, recorrendo à jurisprudência do Tribunal Europeu sobre Direitos Humanos. As Constituições portuguesa e espanhola exigem que a interpretação se dê em consonância com os textos internacionais. A Constituição de Portugal, em seu art. $8^{\circ}, 1$, prevê que as normas de Direito Interacional geral ou comum fazem parte do Direito português. Na República Federal Alemã, o Tribunal Constitucional, em Resolução de 26 de março de 1987, estabeleceu taxativamente que na interpretação da Constituição deve ser considerado o nível de desenvolvimento alcançado na Convenção Europeia de Direitos Humanos, Aliás, a própria Constituição, de 1949, em seu art. 25, prevê que as regras de Direito Internacional prevalecem sobre as leis. A Constituição argentina, em seu art. $75 \$ 22$, considera os principais tratados de direitos humanos como norma constitucional. Na recente Constituição da Venezuela, de dezembro 1999, consagra seu art. 23 que 'Os tratados, pactos e convenções relativos a direitos humanos, subscritos $e$ ratificados pela Venezuela, têm hierarquia constitucional e prevalecem na ordem interna, na medida em que contenham normas sobre o gozo e exercício mais favoráveis às estabelecidas nesta Constituição e nas leis da República, e são de aplicação imediata e direta pelos tribunais e demais órgãos do Poder Público'. É preciso mencionar, ainda, o caso, realmente isolado, da Carta holandesa, de 1956, que inseria os tratados internacionais diretamente em seu sistema normativo, acima da própria constituição”.

${ }^{232}$ Ver TONINI, Paolo. A prova no processo penal italiano, p. 21. Acerca dos princípios relativos à prova ver FIGUEIREDO DIAS, Jorge, Clássicos Jurídicos, p. 187 ss. O autor enumera como princípios relativos à prova o 
O direito à prova foi consagrado em nosso direito pátrio ${ }^{233}$ e em diversos ordenamentos jurídicos $^{234}$, e tratados internacionais ${ }^{235}$ à luz da Convenção Americana de Direitos Humanos (art. 8.2.f $f^{236}$ ). Afinal, constitui a Convenção Americana de Direitos Humanos $^{237} \mathrm{o}$ instrumento de maior importância do sistema interamericano ${ }^{238}$.

Observe-se que a incorporação das garantias contidas na Convenção Americana sobre Direitos do Homem ${ }^{239}$ e no Pacto Internacional sobre os Direitos Civis e Políticos foi de

princípio da investigação ou da 'verdade material', da livre apreciação da prova (ou sistema da 'prova livre') e in dubio pro reo.

${ }^{233}$ GOMES FILHO, Antonio Magalhães. Direito à prova no processo penal, p. 80. "Paralelamente a isso, também merece especial registro o fato de que as nossas Constituições, a partir da República, sempre incluíram, entre os direitos individuais, cláusulas consagradoras do direito de defesa do juízo criminal, cuja leitura não pode excluir o direito à prova. (...) $\mathrm{O}$ atual texto, além de consagrar as tradicionais cláusulas do contraditório e da ampla defesa (art. $5^{\circ}$, inc. LV), também assegura o devido processo legal (art. $5^{\circ}$, inc. LIV) e a presunção de inocência (art. $5^{\circ}$, inc. LVII), dos quais também se extrai o direito de defender-se provando, que não somente é pressuposto de um processo justo e equitativo, mas também condição indispensável para que se possa obter, validamente, a prova da culpabilidade."

${ }^{234}$ FERNANDES, Antonio SCARANCE. Processo Penal Constitucional, p. 66. "No quadro das garantias do devido processo legal, insere-se o direito à prova. Nos Estados Unidos da América constitui-se no right to evidence, garantido pela cláusula do due processo ofLaw. Tem afirmação na jurisprudência da Corte Constitucional Italiana e da Alemanha. É objeto de estudo da doutrina estrangeira e nacional. Vem sendo motivo de preocupação de textos internacionais".

${ }^{235}$ Art. 14.3.e, do Pacto Internacional sobre Direitos Civis e Políticos: "3. Toda a pessoa acusada de um delito tem o direito, em plenitude de igualdade, às seguintes garantias mínimas: (...) e).a interrogar ou fazer interrogar as testemunhas de acusação e a obter o comparecimento e o interrogatório das testemunhas de defesa nas mesmas condições de que dispõe as de acusação"; art. $6^{\circ}$, 3, letra d, da Convenção Européia de Direitos Humanos: "Art. $6^{\circ}$. 3.( ) O acusado tem, como mínimo os seguintes direitos: (...) $d$. Interrogar ou fazer interrogar as testemunhas de acusação e obter a convocação e o interrogatório das testemunhas de defesa nas mesmas condições que as testemunhas de acusação".

${ }^{236}$ Artigo $8^{\circ}$. 2. Toda pessoa acusada de um delito tem direito a que se presuma sua inocência, enquanto não for legalmente comprovada sua culpa. Durante o processo, toda pessoa tem direito, em plenitude de igualdade, às seguintes garantias mínimas: $(. .)$.$f ) direito de defesa de inquirir as testemunhas presentes no Tribunal e de obter$ comparecimento, como testemunhas ou peritos, de outras pessoas que possam lançar luz sobre os fatos.

${ }^{237}$ Ver Opinião Consultiva-02/82, de 24 de setembro de 1982, série A n.2, parágrafo 29, da Corte Interamericana de Direitos Humanos. No original "29 (...) Su objeto y finsonlaprotección de losderechosfundamentales de los seres humanos, independientemente de sunacionalidad, tanto frente a su próprio Estado como frente a losotros Estados contratantes. Al aprobarestos tratados sobre derechoshumanos,los Estados se someten a una orden legal dentro Del cualellos, por elbiencomún, asumen varias obligaciones, no enrelaciónconotros Estados, sino hacialos individuos bajo sujurisdicción.". Ver também §31.

${ }^{238}$ Piovesan, Flávia. Direitos Humanos e Justiça Internacional, p. 87.

${ }^{239}$ Figueiredo Steiner, Sylvia Helena de. A Convenção Americana sobre Direitos Humanos e sua Interpretação ao Processo Penal Brasileiro, p. 50. "A convenção Americana sobre Direitos Humanos, que teve como modelo a Convenção Européia, foi aprovada em 1969, na Conferência Especializada sobre Direitos Humanos realizada em São José da Costa Rica. Daí ser mais conhecida como Pacto de San José da Costa Rica. Com um elenco maior de previsões do que as Convenções anteriores, incorpora também disposições expressas da Declaração Americana e do Pacto de Direitos Civis e Políticos. Entrou em vigor em 1978, após o depósito da ratificação pelo décimo primeiro Estado Americano. Como afirmam Buerghental, Norris e Shelton, o número de direitos que a Convenção Americana proclama é maior que a Convenção Européia, e muitas das disposições estabelecem garantias mais avançadas e abrangentes do que aquela ou o Pacto de Direitos Civis e Políticos. Ainda assim, foi ratificada praticamente por todos os estados americanos com um número mínimo de reservas . 
extrema importância para a consagração definitiva e expressa do direito à prova no ordenamento jurídico brasileiro $^{240}$, não obstante esse direito (ínsito ao direito ao contraditório) já estivesse implícito nas garantias fundamentais asseguradas pela Constituição ${ }^{241}$.

Importa mencionar que, apesar de os textos de direitos humanos, em especial o da Convenção Americana de Direitos Humanos, fazerem menção expressa tão somente ao direito de "inquirir as testemunhas presentes no Tribunal e de obter comparecimento, como testemunhas ou peritos, de outras pessoas que possam lançar luz sobre os fatos" esse dispositivo há de ser interpretado de forma abrangente, aplicando-se a qualquer tipo de prova $^{242}$, devendo a instrução processual penal se desenvolver sob a "garantia da contradição" ${ }^{243}$. O direito à prova constitui direito subjetivo das partes ${ }^{244}$.

O mesmo se diga com relação à Convenção Europeia de Direitos Humanos. Nesse sentir, Trechsel, analisando o direito à prova no Tribunal Europeu de Direitos Humanos,

Estabelece, ainda, dois órgãos para assegurar seu cumprimento efetivo: a Comissão Interamericana de Direitos Humanos e a Corte Interamericana de Direitos Humanos.

${ }^{240}$ Não se há de olvidar que o $\$ 2$, do art. $5^{\circ}$, da Constituição Federal, estabelece que: “os direitos e garantias expressos nesta Constituição não excluem outros decorrentes do regime e dos princípios por ela adotados, ou dos tratados internacionais em que a República Federativa do Brasil seja parte”. Esse princípio insculpido em nossa Carta Maga, manifestamente aplicável ao direito de prova, converge à política global dos direitos humanos, amplamente disciplinada em tratados internacionais.

${ }^{241}$ GOMES FILHO, Antonio Magalhães. Direito à prova (...) op. cit., p. 82/3. "Como visto, nesses dois tratados internacionais é reconhecido a toda pessoa acusada de delito o poder inquirir as testemunhas de acusação, bem como de obter o comparecimento de testemunhas de defesa, em igualdade de condições. E, por força do disposto no art. $5^{\circ}, \S 2^{\circ}$ da Constituição da República, essa garantia possui estatura e dignidade constitucionais, na medida em que complementa e reforça o rol do art. $5^{\circ}$, caput, da Lei Maior, tornando expresso direito que já se entendia implícito em nosso sistema de garantais fundamentais".

${ }^{242}$ GOMES FILHO, Antonio Magalhães. Direito à prova(...)op. cit., p. 74. "Sobre o âmbito de aplicação dessas disposições, cumpre salientar que a referência dos textos unicamente a testemunhas (salvo a menção da Convenção Americana a peritos) não deve levar a entender-se excluída a garantia em relação aos demais meios de prova, pois as redações adotadas estão certamente influenciadas pela tradição anglo-americana, em que há predominância da via testemunhal para introdução de elementos informativos de processo, inclusive no que toca a peritos (expert witness); ademais, tratando-se como visto, de atributo essencial à noção de justo processo, é induvidosamente aplicável a qualquer tipo de prova."

${ }^{243}$ DOTTI, René Ariel. Princípios do processo penal. Palestra apresentada em Assunção em jul/92, por ocasião do Seminário do XIV Congresso de Ass. Internacional de Direito Penal, Fasc. Ci. Penais. Porto Alegre, v. 6, nº 1 , p.89, jan/mar 1993. "a instrução criminal no sistema brasileiro se desenvolve sob a garantia do princípio da contradição, com regras que estabelecem um equilíbrio entre acusação e defesa, quanto à liberdade para produzir e contestar a prova, bem como a garantia em favor de uma parte de responder às alegações da outra".

${ }^{244}$ GOMES, Luiz Flávio. As garantias mínimas do devido processo criminal nos sistemas jurídicos brasileiro e interamericano: Estudo Introdutório, in $O$ sistema interamericano de proteção dos direitos humanos e o direito brasileiro, p.227. Ver também CANOTILHO, José Joaquim Gomes. Estudos sobre direitos fundamentais op. cit, p. 170. "Talvez se possa dizer que, em rigor, o direito constitucional à prova abrange o direito à prova em sentido lato (poder de demonstrar em juízo o fundamento da própria pretensão) e o direito à prova em sentido restrito (alegando matéria de facto e procedendo à demonstração da sua existência)." 
assevera existir fortes evidências de que os direitos previstos no artigo $6^{\circ}, \S 3$ (d) da convenção podem ser aplicados para outras provas além das testemunhais",245.

Destarte, possui o acusado direito à audiência, ao confronto, que não deve, nas lições de DIAS, limitar-se tão somente ao acusado, mas a "todo aquele participante do processo (seja qual for a veste em que intervenha) relativamente ao qual deva o juiz tomar qualquer decisão que pessoalmente o afecte (sic)." 246

Ainda nas palavras de Dias, o direito à audiência ("expressão necessária do direito do cidadão à concessão de justiça") encerra dupla natureza:

"Ele comporta as notas de um direito subjetivo para o seu titular: de um direito subjetivo público, contra o Estado, a ser ouvido perante um tribunal. Não só estas notas, todavia, mas também as constitutivas de uma norma objetiva para a condução do processo perante o tribunal: norma que há-de assegurar ao titular do direito uma eficaz e efectiva (sic) possibilidade de expor as suas próprias razões e de, por este modo, influir na declaração do direito do seu caso." 247

Imperioso ressaltar que, nas nações do mundo ocidental, vige o aspecto garantístico (ou garantista) do processo penal ${ }^{248}$, uma vez que o desenrolar de um procedimento investigativo com vistas à apuração de um fato, em tese criminoso, somente pode se dar por meio de um sistema voltado à proteção de garantias individuais mínimas. ${ }^{249}$

\footnotetext{
${ }^{245}$ TRECHSEL, Stefan. Human Rights in Criminal Proceedings. Oxford: Osxford University Presss, 2005, p. 292.

${ }^{246}$ DIAS, Jorge FIGUEIREDO. Clássicos Jurídicos. p. 158

${ }^{247} I d$. . p. 158. (negritos nossos).

${ }^{248}$ Sobre o garantismo penal, ver FERRAJOLI, Luigi. Direito e razão. Teoria do Garantismo Penal, p.73/4. Nas palavras do mencionado autor, dez termos são condicionantes para a atribuição de pena, quais sejam: "delito, lei, necessidade, ofensa, ação, culpabilidade, juizo, acusação, prova e defesa”, sendo que os axiomas garantistas "não expressam proposições assertivas, mas proposições prescritivas; não descrevem o que ocorre, mas prescrevem o que deva ocorrer (...) não se trata de uma condição suficiente, na presença da qual esteja permitido ou obrigatório punir, mas sim de uma condição necessária, na ausência da qual não está permitido ou está proibido punir".

${ }^{249}$ Neste sentido LOPES JÚNIOR, Aury. O interrogatório online no processo penal: entre a assepsia judiciária e o sexo virtual. Boletim IBCCRIM. São Paulo, v.13, n.154, p. 6-7, set. 2005. "O processo penal é um instrumento a serviço da máxima eficácia dos direitos e garantias fundamentais do acusado, de limitação do poder para obter
} 
Consoante o escólio de Gomes Filho, "dentre os direitos fundamentais proclamados nos vários textos internacionais, merecem destaque aqueles relacionados à proteção dos acusados em processo penal, pois esta sempre foi uma área particularmente propícia às mais brutais violações contra a liberdade, a integridade física e a dignidade do ser humano." 250

Nesse quadro, a elaboração de um sistema forte de garantias judiciais, na esfera processual penal, está intimamente ligada ao desenvolvimento e à efetivação dos direitos humanos em determinado Estado. ${ }^{251}$ Estabelecida essa premissa, pode-se dizer que o direito à prova exsurge como um dos pilares de sustentação do justo processo nas democracias pósmodernas.

Para Gomes Filho, "o direito à prova constitui um dos componentes essenciais e constantes do 'modelo internacional de processo justo' a que se refere Comoglio, e garantem ao acusado não só o direito de obter o comparecimento de testemunhas de defesa (right of attendance), mas também o de participar, em contraditório, da inquirição das testemunhas de acusação (right of confrontation)." 252

Compartilhamos com tal entendimento. Com efeito, o direito à prova deve ser interpretado em sua plenitude, ou seja, o acusado tem direito não só à prova, em sim, mas também aos meios de prova e, por consequência, aos meios de obtenção da mesma. Possui o acusado, pois, direito de participar da atividade probatória de forma ativa, por exemplo, na

o necessário respeito a esfera de dignidade do réu”. Também expõe GRECO FILHO, VICENTE, PEDRO Alessandra Orcesi. A prova penal no contexto da dignidade da pessoa humana. In: Revista do Advogado $n^{\circ} 99$. Associação dos Advogados de São Paulo - AASP. 20 anos da Constituição. Ano XXVII. Setembro de 2008, p.138. "não pode ser entendido senão em função da realização de valores, no centro dos quais se encontra o valor da pessoa humana”. Por fim, não se pode deixar de citar que o texto constitucional prevê como um dos fundamentos da República Federativa do Brasil a dignidade da pessoa humana (vide art. $1^{\circ}$, inciso III da Constituição Federal).

${ }^{250}$ GOMES FILHO, Antonio Magalhães. Sobre o direito à prova no processo penal. São Paulo: Ed. Revista dos Tribunais, p. 73).

${ }^{251}$ Apesar de não fazer menção expressa ao direito à prova, a Declaração Universal dos Direitos do Homem já estatuía, em 1948, que "toda pessoa acusada de delito tem direito a que se presuma sua inocência enquanto não se prove sua culpabilidade, conforme a lei e em juízo público no qual sejam asseguradas todas as garantias necessárias à defesa (art. 11, 1)”. (apud GOMES FILHO, ANTONIO MAGALHÃES. op. cit., p. 73.). Ou seja, logo após o término da Segunda Guerra Mundial o primeiro texto de relevo em matéria de Direitos Humanos já prestava importância à questão das garantias processuais no âmbito do processo penal, o que corrobora a relevância da matéria.

${ }^{252}$ GOMES FILHO, Antonio Magalhães. Direito a prova ..., op. cit., p. 74. Disso decorre que, conclui o autor às fls. 85: que o exercício desse direito deve permear o fenômeno probatório em sua integralidade, ou seja, deve ser possível em todas aquelas tarefas de procura e colheita dos dados que permitirão ao juiz verificar a ocorrência, ou não, dos acontecimentos históricos afirmados pelas partes e sobre os quais irá versar a sentença final". 
colheita da prova testemunhal, mediante a formulação de perguntas às testemunhas, o acompanhamento da realização de perícias, dentre outros.

Nesta esteira, Antonio Magalhães Gomes Filho, considera que

"O reconhecimento de um verdadeiro direito subjetivo à prova, cujos titulares são as partes no processo (penal, no nosso caso), supõe considerar que as mesmas devem estar em condições de influir ativamente em todas as operações desenvolvidas para a constituição do material probatório que irá servir de base à decisão; nessa visão, a prova, antes de tudo, deve ser atividade aberta à iniciativa, participação e controle dos interessados no provimento jurisdicional."

Ademais, TUCCI considera ínsita à contrariedade da instrução criminal a concessão "aos sujeitos parciais integrantes do processo penal, de idênticas possibilidades de oferecer e materializar, nos autos, todos os elementos de convicção demonstrativos da veracidade dos fatos alegados. Bem como de participar de todos os atos probatórios e manifestar-se sobre os seus respectivos conteúdos." 253.

O devido processo legal ${ }^{254}$, inerente ao Estado de Direito, além de "atuar como instrumento de defesa do cidadão perante as intervenções estatais, contribui, por meio de sua efetividade, par ao estabelecimento do Estado Democrático de Direito consagrado pelo texto constitucional em vigor", de acordo com Oliveira Lima." 255

Destarte, conforme insculpido pela Carta Cidadã (artigo $5^{\circ}$, incisos LIV, LV LVII) e pelos diversos sistemas internacionais de direitos humanos, no processo deve ser

\footnotetext{
${ }^{253}$ TUCCI, Rogério Lauria. Direitos e garantias individuais no processo penal brasileiro. $3^{\text {a }}$ edição - São Paulo: Ed. Revista dos Tribunais, 2009, p. 164.

${ }^{254}$ Id, p. 66. “Assim concebido, especifica-se o devido processo penal nas seguintes garantias: a) de acesso à Justiça Penal; b) do juiz natural em matéria penal; c) de tratamento paritário dos sujeitos parciais do processo penal; d) da plenitude de defesa do indiciado, acusado, ou condenado, com todos os meios e recursos a ela inerentes; e) da publicidade dos atos processuais penais; f) da motivação dos atos decisórios penais; g) da fixação de prazo razoável de duração do processo penal; e h) da legalidade da execução penal”.
}

${ }^{255}$ OLIVEIRA LIMA, Miria Rosynete. Devido processo legal, p. 189. 
assegurada uma instrução probatória dinâmica, eficaz e contraditória, possibilitando, aos acusados, o escorreito exercício da ampla defesa ${ }^{256}$ e do contraditório ${ }^{257}$.

Não obstante se tenha assegurado amplitude no direito à prova em matéria penal, tal direito não é absoluto nem poderia $\operatorname{ser}^{258}$, posto que a elucidação dos fatos sem limites poria em risco valores pessoais e sociais de grande grandeza ${ }^{259}$, tais como a intimidade, a vida privada, a honra e imagem, o sigilo de correspondência e telecomunicações telegráficas, o sigilo de dados, o sigilo das comunicações telefônicas, o sigilo profissional, o sigilo bancário e das instituições financeiras, dentre outros de igual magnitude.

\subsection{Considerações gerais acerca da admissibilidade das provas no direito brasileiro}

Embora as provas desempenhem papel preponderante no processo, fixando os fatos a serem apurados ${ }^{260}$, o sistema legal, como já asseverado, não admite a busca da verdade atingível a qualquer custo, limitando, assim, a atuação das partes e do juiz no processo penal.

Destarte, para serem admitidas no ordenamento jurídico, além de serem pertinentes e relevantes ao deslinde da causa, as provas devem ser produzidas de acordo com as normas legais e princípios constitucionais, assegurados pela Carta Cidadã e pelos Direitos

\footnotetext{
${ }^{256}$ SILVA JARDIM, Afrânio da. Bases constitucionais para um processo penal democrático, in Direito processual penal: Estudos e Pareceres, p. 107. "É o próprio interesse social que impõe o exercício da ampla defesa no processo penal, a fim de que, através do método dialético, se alcance a verdade dos fatos, necessária à correta aplicação da lei ao caso concreto. Da mesma forma que não serve aos interesses sociais a absolvição de um culpado, jamais poderá interessar ao Estado a condenação de um inocente. Tais riscos, precisam ser afastados da forma mais eficaz possivel".

${ }^{257}$ Ver GRECO FILHO, Vicente. Tutela Constitucional das liberdades, p.129. "O contraditório pode ser definido como o meio ou instrumento técnico para a efetivação da ampla defesa, e consiste praticamente em: poder contrariar a acusação; poder requerer a produção de provas que devem, se pertinentes, obrigatoriamente ser produzidas; acompanhar a produção das provas, fazendo no caso das testemunhas, as perguntas pertinentes que entender cabíveis; falar sempre depois da acusação; manifestar-se sempre em todos os atos e termos processuais aos quais devem estar presentes; recorrer quando inconformado”. Sobre o contraditório e ampla defesa ver também AlmeIDA, Joaquim Canuto Mendes de, Princípios fundamentais do processo penal, p. 93 ss.

${ }^{258}$ LIMA, Marcellus Pastri. As provas vedadas no processo penal brasileiro-vedação de produção e eventual possiblidade de sua utilização, p. 127. "No Brasil, tanto a doutrina como a disciplina legislativa em relação às provas ilícitas foram construídas tendo em vista a experiência dos Estados Unidos da América, onde há muito foi fixado o princípio da inadmissibilidade da provas obtidas ilicitamente e conforme doutrina brasileira, sendo reconhecido tal defeito da prova, a princípio, esta não poderia se aceita no processo. Ver caso Weeks, da Suprema Corte Americana.

${ }^{259}$ Ver BARROS, Marco Antonio de. A Busca da Verdade no Processo Penal, p. 216.

${ }^{260}$ GOMES FILHO, Antonio Magalhaes. Direito a prova no processo penal, p. 92.
} 
Humanos. Verifica-se, portanto, que o direito à prova restringe-se pelas regras de admissibilidade ${ }^{261}$.

Beling (apud MAIER ${ }^{262}$ ), analisando o tema das proibições probatórias, acentua que, no direito processual penal, "existe um núcleo de problemas muito conexos à vigência real das garantias constitucionais, no que se refere aos limites da aquisição do conhecimento necessário para decidir acerca do objeto do procedimento, o fato punível imputado, isto é, se vincula a esses nomes sempre com os limites da atividade probatória no processo penal."

Prossegue o autor:

"Alguns põem ênfase no começo desta atividade (proibições ao oferecimento ou a recepção das provas $=$ Beweiserheburgsverbote) , outros se referem principalmente ao momento final desta atividade, quando a prova rende seus frutos, é valorada (proibição sobre a valoração probatória $=$ Beweisverwertungsverbote), outros preferem generalizar (proibições probatórias = Beweisverbote; así, Beling) e, por fim, algumas designações tem em vista o efeito específico que se deseja atribuir a inobservância das regras que estabelecem os limites desta atividade (exlcusionaryrule, supressiondoctrine o fruitofthepoisnoustree).”

Nesse sentir, conforme ensinamentos de Costa Andrade:

\footnotetext{
${ }^{261}$ MARQUES, José Frederico. Elementos de Direito Processual Penal, p. 256. "De um modo geral, são inadmissíveis os meios de prova que a lei proíba e aqueles que são incompatíveis com o sistema processual em vigor".

262 Tradução livre BELING, Ernst. citado por MAIER, Julio B. J. Derecho procesal penal. I. Fundamentos, p. 696/7. “Empero, todos los títulos antecipados han adquirido, por el momento, carta de ciudadanía para expressar, em elDerechoprocesal penal, um núcleo de problemas muy conexo a lavigencia real de las garantias constitucionales, referidos a los limites de al adquisicióndelconociemineto necessário para decidir acerca del objeto del procedimento, elhechopunible imputado, esto es, se vincula a essosnombressiempre com loslímites de laactividad probatória em el processo penal. Algunos de ellosponenel acento em elcomienzo de esaactividad (prohibiciones al oferecimento o a lareception de laprueba $=$ Beweiserhebungsverbote), otros se refieren principalmente al momento final de esaactividad, cuaondolapruebarinde sus frutos, es valorada (prohibiciones sobre lavaloración probatória = Beweisverwerbote; así, Beling) y, por fin, algunasdesignacionestienen em miras o efecto específico que se desea atribuir a la inobservância de lasreglas que establecenloslimítes de esaactividad (exclusionaryrule, supressiondoctrine o fruti os thepoionoustree)".
} 
“[...] numa consideração mais genérica das coisas, dificilmente, por seu turno, se compreenderia que, na prossecução das suas tarefas, o Estado passasse de boa consciência por sobre as normas que balizam a ilicitude penal. O que vale mesmo em se tratando duma tarefa com a transcendência axiológica-material da realização da justiça criminal; justamente em nome do lastro ético que define como justiça e lhe outorga a necessária legitimação processual e material. Como nesta linha, enfatiza Amelug, o Estado cairá em contradição normativa e comprometerá a legitimação da própria pena se, o próprio Estado violar o mínimo ético para lograr a aplicação de uma pena. Desse modo, ele mostra que pode valer a pena violar qualquer norma fundamental cuja vigência o direito penal se propõe precisamente assegurar." 263

Ora, por mais louvável que seja o princípio da busca da verdade real ou atingível, essa somente pode ser aferível mediante o respeito às mínimas garantias do ser humano (direito à dignidade, vida privada, sigilo, propriedade, personalidade, integridade física e moral, dentre outros), ou seja, a persecução penal deve obedecer a critérios éticos, morais e convergentes aos direitos individuais do cidadão, não se admitindo as provas ilegítimas ou ilícitas ${ }^{264}$.

\footnotetext{
${ }^{263}$ COSTA ANDRADE, Manuel da. Sobre as proibições de prova no processo penal, p. 15.

${ }^{264}$ Ver GRINOVER, Ada Pellegrini, FERNANDES. Antonio Scarance e GOMES FILHO, Antonio Magalhães, As nulidades no processo penal, $12^{\mathrm{a}}$ ed., revista e atualizada, São Paulo: RT, 2011, p. 126/7. “A prova ilícita (ou obtida por meios ilícitos) enquadra-se na categoria da prova vedada. A prova é vedada sempre que for contrária a uma específica norma legal, ou a um princípio do direito positivo. Mas a vedação pode ser estabelecida quer pela lei processual, quer pela norma material (por exemplo, constitucional ou penal); pode, ainda, ser expressa ou pode implicitamente ser deduzida dos princípios gerais. No campo das proibições da prova, a tônica é dada pela natureza processual ou substancial da vedação: a proibição tem natureza exclusivamente processual quando for colocada em função de interesses atinentes à lógica e à finalidade do processo; tem, pelo contrário, natureza substancial quando, embora servindo imediatamente também a interesses processuais, é colocada essencialmente em função dos direitos que o ordenamento reconhece aos indivíduos, independentemente do processo. A distinção é relevante: a violação do impedimento configura, em ambos os casos, uma ilegalidade; mas, enquanto no primeiro caso haverá um 'ato ilegítimo', no segundo caso haverá um 'ato ilícito' (Nuvolone). Acompanhando essa terminologia, diz-se que a prova é ilegal toda vez que sua obtenção caracterize violação de normas legais ou de princípios gerais do ordenamento, de natureza processual ou material. Quando a proibição for colocada por ume lei processual, a prova será ilegítima (ou ilegitimamente produzida); quando, pelo contrário, a proibição for de natureza material, a prova será ilicitamente obtida”.
} 
Não obstante se assevere que a Constituição Brasileira, ao preconizar a inadmissibilidade da prova ilícita, tenha pretendido englobar os dois tipos de prova ilegais ilegítimas e ilícitas - faz-se necessário distingui-las ${ }^{265}$.

Conforme preceitua a doutrina, as provas ilegítimas são aquelas obtidas com violação ao direito processual, já as ilícitas ${ }^{266}$ são as obtidas com desrespeito ao direito material $^{267}$.

Bastos e Martins ${ }^{268}$ enfatizam que a ilegalidade ou ilicitude intrínseca refere-se ao vício que incide na prova de um desvio processual, ou seja, aqueles que ocorrem no caminho da geração da prova, ofendendo as normas que disciplinam as próprias produções das provas. Já a ilicitude ou ilegalidade extrínseca, refere-se à mácula das provas produzidas com ofensa a um direito individual ou fundamental.

No escólio desses autores, existe um descabimento manifestado das provas ilegítimas, afinal, “a prova gerada de forma injurídica não poderia produzir efeitos, mesmo sem uma cominação legal dessa pena de nulidade. É que a decorrência normal do ato inválido é a sua não produção de efeitos jurídicos." 269.

O diploma processual penal preconiza diversas regras que devem ser respeitadas: v.g.: art. 158, do CPP - exige laudo pericial nas infrações que deixarem vestígio; art. 207, do CPP - vedação da prova testemunhal de pessoas que, por lei, devam guardar segredo, como advogados, médicos e outros; art. 208, do CPP - não deferência do compromisso aos doentes e deficientes mentais e aos menos de 14 anos, dentre outros.

Já com relação à ilegalidade extrínseca, prosseguem Bastos e Martins, o problema se coloca de forma mais complexa, posto que "a não aceitação da prova daí advinda seria a proteção à que a ordem jurídica há de conferir aos direitos das pessoas, mas ninguém pode

\footnotetext{
${ }^{265}$ LIMA, Marcellu Polastri. As provas vedadas (...) op. cit., p. 133.

${ }^{266}$ Conforme o artigo $5^{\circ}$, inciso LVI, da CF/88. São inadmissíveis no processo, as provas obtidas por meios ilícitos. No mesmo sentido estabelece o diploma processual penal, no artigo 157, caput e $\S 1^{\circ}$. "São inadmissíveis devendo ser desentranhadas do processo, as prova ilícitas, assim entendidas as obtidas em violação às normas constitucionais e legais. $\$ 1^{\circ}$. São também inadmissíveis as provas derivadas das ilícitas, salvo quando não evidenciado o nexo de causalidade entre umas e outras, ou quando as derivadas puderem ser obtidas por uma fonte independente das primeiras".

${ }^{267}$ MORAES, Alexandre. Constituição do Brasil interpretada, p. 380. "As prova ilegais seriam o gênero do qual as espécies são as provas ilícitas e as ilegítimas, pois configuram-se pela obtenção com violação de natureza material ou processual ao ordenamento jurídico".

${ }^{268}$ BASTOS, Celso Ribeiro e MARTINS, Ives Gandra. Comentários à Constituição do Brasil, p. 274.

${ }^{269}$ BASTOS, Celso Ribeiro e MARTINS, Ives Gandra. op. cit., p. 275.
} 
negar, que a prova pode ter sido, no que diz respeito à sua geração, uma prova legal” ${ }^{, 270} . E$. $g$. não se admite a prova obtida por meio da tortura ou de maus tratos (art. $5^{\circ}$, III da $\left.\mathrm{CF} / 88\right)^{271}$, com violação do domicílio (art. 5, XI da CF/88), das comunicações (art. $5^{\circ}$, XII, da CF/88), da intimidade e da vida privada (art. $5^{\circ}, \mathrm{X}$, da $\mathrm{CF} / 88$ ), dentre outras.

A distinção entre prova ilegítima e prova ilícita é imprescindível para a análise de seus efeitos no processo. Enquanto a prova ilegítima (que viola direito processual) será considerada nula, podendo, entretanto, vir a ser renovada no processo de forma escorreita (art. 573, do CPP), a prova ilícita (que viola direito material) é inadmissível, devendo ser desentranhada dos autos (art. 157, caput, do CPP $)^{272}$.

A questão acerca da licitude - e, por via de consequência óbvia, da moralidade da prova elevada como princípio de ordem constitucional, na condição de direito individual projeta o tema para um fundamento de direitos humanos ${ }^{273}$. Há inegável vinculação entre a não aceitação da ilicitude da prova e os direitos fundamentais.

O artigo $11^{\circ}$ da Convenção Americana de Direitos Humanos determina a proteção da honra e da dignidade:

"1. Toda pessoa tem direito ao respeito de sua honra e ao reconhecimento de sua dignidade. 2. Ninguém pode ser objeto de ingerências arbitrárias ou abusivas em sua vida privada, na de sua família, em seu domicílio ou em sua correspondência, nem de ofensas ilegais à sua honra e reputação. 3. Toda pessoa tem direito à proteção da lei contra tais ingerências ou tais ofensas."

\footnotetext{
${ }^{270}$ BASTOS, Celso Ribeiro e MARTINS, Ives Gandra. ob cit, , p. 275.

${ }^{271}$ Ver Decreto 40/ 91 (Convenção contra a tortura e outros tratamentos ou penas cruéis, desumanos ou degradantes) e Decreto 98.386/89 (Convenção interamericana para prevenir e punir a tortura).

${ }^{272}$ Ver GRINOVER, Ada Pellegrini, FERNANDES, AntonioScarance e GOMES FILHO, Antonio Magalhães. As nulidades no processo penal, p. 127. "Não parece ter sido a melhor opção da Lei 11.690/2008, ao definir a prova ilícita como aquela 'obtida em violação a normas constitucionais ou legais', (nova redação do art. 157 CPP). A falta de distinção entre a infringência da lei material ou processual pode levar a equívocos e confusões, fazendo crer, por consequência, o seu desentranhamento do processo. O não cumprimento da lei processual leva à nulidade do ato de formação da prova e impõe a sua renovação nos termos do art. 573, do CPP”.

${ }^{273}$ Nas corretas colocações de MELLO, Rodrigo Pereira de. Provas Ilícitas e sua Interpretação Constitucional, p. 817/818, Tratando-se de prova ilícita, é essencial a consideração de que ela ocorre onde há inobservância de preceitos de direito material para sua colheita. Nestes destacam-se os direitos individuais constitucionalizados, cabendo mesmo afirmar que a prova ilícita se define como aquela que viola os princípios constitucionais da intimidade, sigilo das comunicações, domicílio, integridade e imagem das pessoas.
} 
Por sua vez, o artigo $8^{\circ}$ da Convenção Europeia dos Direitos Humanos estabelece o direito ao respeito pela vida privada e familiar:

“1. Qualquer pessoa tem direito ao respeito da sua vida privada e familiar, do seu domicílio e da sua correspondência. 2. Não pode haver ingerência da autoridade pública no exercício deste direito senão quando esta ingerência estiver prevista na lei e constituir uma providência que, numa sociedade democrática, seja necessária para a segurança nacional, para a segurança pública, para o bem - estar econômico (sic) do país, a defesa da ordem e a prevenção das infracções (sic) penais, a proteção da saúde ou da moral, ou a proteção dos direitos e das liberdades de terceiros."

Em que pese existirem divergências doutrinárias acerca da admissibilidade ou não da prova ilícita, ultimamente vem ganhando espaço a teoria da proporcionalidade ${ }^{274}$ que “adota o princípio da proporção ou ponderação de interesses, admitindo a valoração da prova ilícita mesmo ante vedação constitucional, em casos excepcionais"275.

\footnotetext{
${ }^{274}$ Cf. WAMBIER, Luiz Rodrigues. in op. cit., p. 417, ao classificar as provas ilícitas e suas repercussões: "Atualmente, três são as correntes sobre otema: a) obstativa: considera inadmissivel a prova obtida por meio ilícito, em qualquer hipótese e sob qualquer argumento, não cedendo mesmo quando o direito em debate mostra elevada relevância. Derivação desse entendimento é a 'teoria do fruto da árvore envenenada', que considera que o ilícito na obtenção da prova contamina não apenas o resultado havido mas até as provas subsequentes que só puderam ser produzidas graças à obtenção da prova ilícita; b) permissiva: aceita a prova assim obtida, por entender que o ilícito se refere ao meio da obtenção da prova, não a seu conteúdo. Entende que aquele que produziu o meio de prova deve ser punido, mas o conteúdo da prova aproveitado; c) intermediária: admite-se a prova ilícita, dependendo dos valores jurídicos e morais em jogo. Aplica-se o princípio da proporcionalidade", in ob. cit., p. 417.
}

${ }^{275}$ Ver. LIMA, Marcellus Polastri. As provas vedadas no processo penal brasileiro - vedação de produção e eventual possibilidade de sua utilização, p. 128. "Existiam, na doutrina brasileira, quatro corrente em relação à questão da admissibilidade da prova ilícita, a saber: Pela primeira, em não havendo impedimento na lei processual acerca da utilização da prova obtida ilicitamente (aquela que ofende as leis materiais ou a Constituição), somente a prova ilegítima (aquela que ofende a lei processual) poderia ser vedada no processo e, no que tange à prova ilícita, somente ficaria reconhecido o vício material, punindo-se o autor de sua produção, mas a prova permaneceria válida no processo (...); Três outras correntes davam por inadmissíveis as provas ilícitas no processo penal: uma, sob o fundamento de que, se o direito é uno, a se a prova é ilícita, tal ilicitude deveria ser considerada em todos os ramos do direitos assim, não poderia a prova ilícita ser reconhecida e utilizada no processo (Pietro Nuvuolone, na Itália e Frederico Marques e Heleno Fragoso no Brasil); outra se baseava no fato de que o Estado deve se ater ao princípio da moralidade, não podendo, se utilizar de meios ilícitos, nem mesmo para combater o crime; e, ainda, havia outra corrente (a terceira) que defendia que a prova 
Nesse sentido, Scarance Fernandes assevera que "a norma constitucional que veda a utilização no processo de prova obtida por meio ilícito deve ser analisada à luz do princípio da proporcionalidade ${ }^{276}$, devendo o juiz, em cada caso, sopesar se outra norma, também constitucional, de ordem processual ou material, não supera em valor aquela que estaria sendo violada" 277 .

O próprio autor ressalva que "[...] há posicionamento diverso entre os doutrinadores a respeito da extensão do princípio da proporcionalidade” ${ }^{278}$, embora pareça remansoso o entendimento de que, em favor da defesa do acusado, a prova ilícita deve ser aceita, incondicionalmente ${ }^{279}$, ainda que infrinja direitos fundamentais do acusado ou de terceiros. Afinal, não interessa ao próprio Estado a punição do inocente.

Justificando tal entendimento, Gomes Filho esclarece:

“[...] são semelhantes considerações a respeito da ponderação de interesses que autorizam a admissão da prova ilícita 'pro reo': no confronto entre uma proibição de prova, ainda que ditada pelo interesse da proteção a um direito fundamental, e o direito à prova da inocência parece claro que deva este último prevalecer, não só porque a liberdade e a dignidade da pessoa humana constituem valores insuperáveis, na ótica da sociedade democrática, mas também porque

ilícita ofenderia a Constituição, atingindo valores fundamentais do indivíduo e as garantias individuais (Cappeleti, Vigoriti e Comoglio, na Itália) e, entre nós, Ada Pellegrini Grinover".

${ }^{276}$ Ver MAGALHÃES GOMES, Mariângela Gama de. O princípio da proporcionalidade do direito penal, p. 59. “Com relação, especificamente, à proporcionalidade, sua natureza de princípio jurídico é evidenciada quando, à parte da generalidade e do aspecto vago do que impõe (pode-se dizer que este princípio determina que a norma jurídica deva ser proporcional à situação de fato disciplinada), é possível também verificar que se encontra entre as normas superiores do ordenamento jurídico, de nível constitucional, razão pela qual norteia toda a atividade penal, seja no âmbito legislativo, seja na aplicação da lei aos casos concretos. (...). Evidencia-se, em primeiro lugar, sua característica de verdadeiro standart juridicamente vinculante, informado pelas exigências da justiça, ínsita a todo o ordenamento. Além disso, a proporcionalidade apresenta uma importância estruturante em todo o sistema jurídico, atuando, especificamente, por meio de mandado de otimização no sentido de que os imperativos de necessidade, idoneidade e proporcionalidade em sentido estrito sejam atendidos e limitem as intervenções estatais no âmbito das esferas individuais - o fato de ser reconhecido também o poder do Estado de limitar os direitos individuais não invalida os subprincípios componentes da proporcionalidade, mas apenas, estabelece os limites até onde podem atuar".

${ }^{277}$ FERNANDES, Antonio Scarance. Processo Penal Constitucional, p. 82.

${ }^{278} I d$., p. 82

${ }^{279} I d$., p. 82 "É ampla a aceitação de que seja ele (o princípio da proporcionalidade) aplicado aos casos em que a prova da inocência do réu depende de prova produzida de maneira ilícita. Não se conseguiria justificar a condenação, até mesmo a pena elevada, de uma pessoa quando há nos autos prova de sua inocência, ainda que tenha sido obtida por meios ilícitos". 
ao próprio Estado não pode interessara punição do inocente, o que poderá significar a impunidade do verdadeiro culpado; é nesse sentido, aliás, que a moderna jurisprudência norte-americana tem afirmado que o direito à prova de defesa é superior." ${ }^{280}$.

Tem-se admitido ainda que a prova "ilícita" colhida pelo próprio acusado pode ser utilizada, vez que sua ilicitude seria "eliminada por causas legais, como a legítima defesa, que exclui a antijuridicidade. Assim, na jurisprudência e na doutrina estrangeiras, tem sido vista a conduta da pessoa que grava sub-repticiamente sua conversa com terceiro para demonstrar a própria inocência." 281

Por outro lado, há quem sustente que esse princípio também poderia ser utilizado para a aceitação da prova ilícita acusatória, em virtude da existência do princípio da paridade de armas ${ }^{282}$. Entretanto, essa não é a melhor opção a ser adotada, pois significaria intolerável banalização dos direitos individuais consagrados na Carta Cidadã e nos Tratados de Direitos Humanos $^{283}$.

Note-se, ademais, que a doutrina e a jurisprudência têm admitido a aplicação do princípio da proporcionalidade, no que diz respeito às provas ilícitas por derivação (teoria dos frutos da árvore proibida), quando a conexão entre essas provas for tênue

\footnotetext{
${ }^{280}$ GOMES FILHO, Antonio Magalhães. op. cit. p. 106.

${ }^{281}$ Ver GRINOVER, Ada Pellegrini, FERNANDES, Antonio Scarance e GOMES FILHO, Antonio Magalhães. As nulidades no processo penal, p. 129/30.

${ }^{282}$ FERNANDES, Antonio Scarance. Processo Penal Constitucional, p. 83. "Outros entendem que o princípio também pode servir à acusação, justificando-se com o princípio da isonomia, principalmente em face da crescente criminalidade organizada".

${ }^{283} I d$, p. 104. "Como já mencionado, a temática das proibições de prova se funda não somente na necessidade de se assegurar uma correta reconstrução dos fatos, mas também ressalta a ideia de que a atividade probatória deve ser limitada diante da tutela conferida pelo ordenamento a outros valores, que se sobrepõem à busca da verdade judicial; enfim, nessa última hipótese, é a ponderação entre os interesses em conflito que justifica a exclusão. Essa mesma consideração p ode implicar, em outras situações especiais, a prevalência do interesse na obtenção da prova sobre o valor cuja proteção é almejada pela regra da proibição: fala-se, então, em razoabilidade, ou proporcionalidade, como princípio que autoriza a superação das vedações probatórias. (...). Tal posição não constitui, entretanto, uma unanimidade na doutrina, sendo bastante veementes as críticas daqueles que consideram intolerável uma compreensão dos direitos fundamentais para a repressão de determinados delitos, pois isso significa admitir uma banalização dos referidos direitos, cuja eficácia na matéria examinada, ficaria limitada aos agentes de delitos menos graves, enquanto nas situações de criminalidade mais grave haveria sempre uma frustração da tutela dos direitos fundamentais.(...) De qualquer forma, não se pode contestar que o critério de proporcionalidade encontra hoje agasalho nos textos legislativos destinados a dar maior severidade à repressão do crime organizado, do tráfico de entorpecentes, e de outras expressões mais agudas da criminalidade".
} 
(independentsource), ou ainda quando a prova derivada puder ser obtida de outra maneira (inevitabeldiscovey). Essas restrições aos limites da teoria da árvore envenenada têm sido admitidas nos Estados Unidos da América, na Europa ${ }^{284}$ e no Brasil ${ }^{285}$.

Por fim, necessárias são algumas considerações sobre a prova emprestada, questão que certamente se sobreleva em relação aos tratados internacionais.

Dentre os expedientes judiciais que melhor incorporam o propósito de tornar práticos os princípios processuais da celeridade e economia processuais, encontra-se a prova emprestada, que nada mais é do que a possibilidade de se utilizar, nos autos de um processo judicial, de prova produzida em outro feito ${ }^{286}$.

Contudo, existem alguns requisitos que necessariamente precisam ser superados para que a prova emprestada seja considerada válida no segundo processo, divergindo a doutrina com relação a esses ${ }^{287}$.

\footnotetext{
${ }^{284}$ GRINOVER, Ada Pellegrini, FERNANDES, Antonio Scarance e GOMES FILHO, Antonio Magalhães. As nulidades no processo penal, p. 130/1. "As restrições da jurisprudência norte-americana à inadmissibilidade das provas ilícitas por derivação são acolhidas pelas Cortes Constitucionais europeias: assim, o Tribunal Constitucional espanhol, a partir do reconhecimento da teoria dos frutos da árvore envenenada, em 1984, vem estabelecendo a necessidade e de uma estreita vinculação das provas derivadas das ilícitas para descarta-las (sentença n. 81/1998); e o Tribunal Constitucional português, em março de 2004, apoiando-se na posição norteamericana, minuciosamente descrita, embora considerando ilícitas as interceptações telefônicas realizadas no caso concreto, não invalidou a sucessiva confissão do acusado, por reputar inexistente o nexo causal (efeito à distância) entre umas e outra (Acórdão n. 198/2004)".

${ }^{285}$ Ver. STF-1 $1^{\text {a }}$ Turma, HC 106244-Rio de Janeiro - "CONSTITUCIONAL, PENAL E PROCESSUAL PENAL. PROVA ILÍCITA. CONTAMINAÇÃO DO CONJUNTO PROBATÓRIO: DERIVAÇÃO INEXISTENTE. LEGALIDADE DE PRORROGAÇÕES DO PRAZO INICIAL DA ESCUTA. ELEVADO NÚMERO DE TERMINAIS ALCANÇADOS PELA MEDIDA: POSSIBILIDADE. QUALIDADE DA DEGRAVAÇÃO DAS ESCUTAS TELEFÔNICAS: TEMA ESTRANHO AOS LIMITES DO HABEAS CORPUS. 1. As referências às escutas telefônicas empreendidas sem autorização judicial, por ilícitas, devem ser desentranhadas dos autos, na esteira do que determina o inciso LVI do art. $5^{\circ}$ da Constituição da República. Precedentes. 2. A ilicitude de uma prova não contamina os demais elementos cognitivos obtidos e que dela não derivaram. Precedentes. 3. O tempo das escutas telefônicas autorizadas e o número de terminais alcançados subordinam-se à necessidade da atividade investigatória e ao princípio da razoabilidade, não havendo limitações legais predeterminadas. Precedentes. 4. Eventuais deficiências qualitativas na tradução do material degravado não invalidam a prova regularmente colhida, devendo o tema ser tratado no curso da instrução da ação penal, considerados os limites do habeas corpus. 5. Ordem denegada" (Rel. Min. Cármen Lúcia, julg. 17/05/2011).
}

${ }^{286}$ Conforme WAMBIER, Luiz Rodrigues. op. cit., p. 413. "Nesses casos a prova é transportada do primeiro para o segundo processo sob a forma documental. Ou seja, são apresentadas cópias dos documentos que a formalizaram no processo de origem. Por exemplo, se o empréstimo é de uma prova testemunhal, são trazidas para o segundo processo cópias da petição de requerimento da prova testemunhal, da petição de arrolamento da testemunha, da decisão de deferimento da prova, do termo de audiência em que a testemunha foi ouvida, etc".

${ }^{287}$ Ver DEZEN, Guilherme Madeira. Da prova penal. Tipo processual, provas típicas e atípicas. Atualizado de acordo com as Leis 11.689, 11.690/08 e 11.719/08, p. 108 ss. 
O primeiro requisito, aceito unanimemente, refere-se à necessidade de que a pessoa contra quem a prova será utilizada tenha participado da produção dessa prova no outro processo (que originou a prova), exercendo o contraditório.

Entretanto, existem outras duas correntes doutrinárias que exigem outros requisitos indispensáveis à admissibilidade da prova emprestada, assim, sua análise exige maior cautela.

Para a primeira corrente, devem ser cumpridos os seguintes requisitos: i) que a prova tenha sido colhida em processo perante as mesmas partes ou em processo que tenha figurado como aquele contra quem se pretenda fazer valer a prova; e ii) ser colhida perante o juiz natural da causa (ou seja, o mesmo juiz constitucionalmente competente).

Por sua vez, a outra corrente exige como requisitos da prova emprestada: i) ser colhida em processo perante as mesmas partes; ii) observância, no processo anterior, das formalidades previstas em lei para a produção da prova; iii) que o fato probando seja o mesmo; e iv) que tenha havido contraditório no processo do qual a prova será transferida.

Note-se ainda que a prova emprestada deve ser considerada válida no processo de origem. Destarte, por exemplo, uma confissão eivada de vício no primeiro processo não poderá ser utilizada no segundo.

Tais requisitos de admissibilidade são importantes e repercutem no processo cooperacional, em especial a exigência de que a prova emprestada que tenha sido produzida tenha sido submetida ao contraditório entre as partes, em ambos os processos.

De início, diga-se que os acordos de cooperação, em regra, dispensam a necessidade de consularização do documento que se prestará a servir de prova emprestada, tramitando apenas por meio da Autoridade Central.

Observe-se que a prova emprestada diz respeito a mero procedimento - e não a princípios probatórios - de modo que a necessidade de que, realmente, tenha o acusado participado da prova no processo de origem não se consubstancia em mero exercício formal, mas na própria essência do direito de prova.

Importa reiterar, igualmente, a exigência do contraditório para a validade da prova, ainda que postergado, diferido (nos casos nos quais a ciência do investigado pode frustrar a prova), com a presença das partes, tendo-lhes sido ofertadas iguais oportunidades de se 
manifestar sobre essas (paridade de armas), é assegurada pelo nosso Ordenamento Jurídico, e pelas Convenções Internacionais sobre Direitos Humanos ${ }^{288}$.

Nesse sentir, pode-se afirmar que:

“[...] a exigência do contraditório, na formação e produção das provas vem desdobrada em diversos aspectos, que se podem assim resumir: a) proibição de utilização de fatos que não tenham sido previamente introduzidos pelo juiz no processo e submetidos a debate pelas partes; b)a proibição de utilizar provas formadas fora do processo ou de qualquer modo colhidas na ausência das partes; c) a obrigação do juiz, quando determine a produção de provas exofficio, de submetê-las ao contraditório das partes, as quais devem participar de sua produção e poder oferecer a contraprova. (...) Em última análise, tanto será viciada a prova que for colhida sem a presença do juiz, como o será a prova colhida pelo juiz, sem a presença das partes.”

Tarzia enfatiza que o contraditório substancial e não só formal, só pode ser produzido em um processo no qual as partes possuam as mesmas condições ${ }^{289}$ de buscar as fontes e meios de prova, requerer a produção, contrapor as provas produzidas pela parte contrária e vê-las valoradas.

A diversidade de sistemas e de opções internas, na ponderação de valores de segurança pública e de direitos individuais (tais como intimidade, vida privada etc.) - consiste um grande obstáculo à cooperação jurídica penal ativa, em matéria de prova.

\footnotetext{
${ }^{288}$ Como preconiza UBERTIS, Giulio. Il contraddittotionellaformazionedella prova penale, in Estudos em homenagem a professora Ada Pellegrini Grinover, p. 332/3. "Ill contradditroio, peraltro, postula cheagliantagonisti sai riconsciuta uma posizione de parità. Se, inverso, lapratitàtrale parti, di per sé, non realiza necessariamente ilcontraddittorio (potrebbeesserenegata a tutti i tilolari dei rispettiviinteressilapossibilitàdiinterloquire al giudice, avendosiallora uma paritàsenzacontraddittorio), ètuttaviaimpossibileriscontrarelasussistenza tale per cuileragioni i protagonistidella controvérsia si trovano in uma situazione tale per cuileragionidell'unoabbiano uma possibilitàdiesplicazionemaggiorerispetto a quelledell'atro.(...) Inoltre, lagaranzia per l'accusatodi non esserecollocato in situazionidisvantaggiotali da comportareilrischiodi um decisionefondatasuelementi non sottoposti al pricipiodellaparitàdellearmitrale parti opera lungotuttol'arcodel procedimento, ivi compres ele eventual fasi sai incidentali (come quellerelativealledecisioni in matéria dilibertàpersonale) chediipugnazione
}

${ }^{289}$ TARZIA, Giuseppe. Parità dele armitrale parti e poteridelgiudicenel processo civile, Problemidelprocesso civiledicognizione, p. 312/4. 
Afinal, não obstante, grande parte dos países tenha aderido e constitucionalizado aos direitos humanos como direitos fundamentais, inclusive aqueles afetos ao justo processo, a diversidade sobre as opções locais acerca do alcance destes direitos é enorme. Diante deste quadro existem sensíveis questões relacionadas à violação de sigilo, da intimidade, da vida privada, do direito de propriedade, do direito ao silêncio etc. Estas questões serão analisadas mais adiante.

De tudo o quanto se afirmou até agora, depreende-se que assim como o procedimento probatório necessita de uma metodologia procedimental ampla, a matéria acerca da legalidade da prova requer uma sistematização com relação a sua origem, conteúdo e relevância, no sentido que se possa aferir acerca de sua licitude, sempre adequando o princípio da busca pela verdade atingível, com a da defesa dos direitos fundamentais do cidadão, com a adoção, no nosso sentir, do princípio da proporcionalidade, como o mais apto a alcançar esse anseio de ordem jurídico-processual ${ }^{290}$.

\footnotetext{
${ }^{290}$ Cf. CLÈVE, Clêmerson Merlin e FrEIRE, Alexandre Reis Siqueira. Algumas Notas Sobre Colisão de Direitos Fundamentais, in Estudos de Direito Constitucional em Homenagem a José Afonso da Silva, p. 239.
} 


\section{Grandes questões do direito à prova na cooperação jurídica internacional da atualidade.}

A cooperação jurídica internacional em matéria penal está em contato com a constelação de Estados, devendo ser feita uma coordenação das opções locais dos diversos países, para que seja viável esta colaboração interestatal, na busca da paz mundial e da preservação das garantias fundamentais universalmente consagradas.

Em que pese o mundo atual clamar, cada vez mais, pelo recrudescimento das políticas de repressão penal, dada insegurança e incertezas acerca dos rumos do combate à criminalidade, que ultrapassa fronteiras, de forma dinâmica, é preciso encontrar um equilíbrio entre a necessidade do da preservação do jus puniendi e do jus libertatis.

Neste diapasão, traz-se à colação as sabias palavras de Aury Lopes Jr. Ao constatar que "Considerando que o risco, violência e insegurança sempre existirão, é sempre melhor risco com garantias do que risco com autoritarismo ${ }^{, 291}$.

É sob este prisma, de um processo penal célere, mas garantista, com respeito aos direitos humanos inerentes ao frair trail, que deve ser analisada à cooperação jurídica internacional penal, em matéria de prova.

Ao se analisar a disciplina da prova, é imprescindível ter em conta que ela está, como bem assentado por Gomes Filho "impregnada por fatores sociais, políticos e culturais", constituindo "a disciplina das provas é o ponto central de qualquer sistema processual penal, refletindo a orientação ideológica do legislador diante do dilema entre a busca da verdade e a proteção dos interesses da sociedade e do indivíduo na tarefa de verificação dos fatos." 292

Em que pese a cooperação jurídica ser vista, como deve ser, como um instrumento facilitador da obtenção de fontes, meios de prova e de obtenção de provas, que se encontrem

\footnotetext{
${ }^{291}$ LOPES JR., Aury Lopes. (Re) Descobrindo as teorias acerca da natureza jurídica do processo (penal), in Doutrinas essenciais. Processo penal, p. 64.

${ }^{292}$ GOMES FILHO, Antonio Magalhães. Breves Anotações Sobre a Temática das Provas no Projeto de Código de Processo Penal (Projeto $\mathrm{n}^{\circ} 156 / 2009$ do Senado Federal), in Revista do Advogado $\mathrm{n}^{\circ}$ 113, 2011, p. 35. Prossegue o autor: "É que a atividade probatória está fortemente impregnada por fatores sociais, políticos e culturais, pois o seu objetivo não é apenas o de estabelecer uma verdade circunscrita ao processo, mas um conhecimento sobre os fatos que possa justificar a futura decisão perante a sociedade, Por isso, é natural que essa atividade esteja submetida a certa regras - lógicas, psicológicas, éticas e jurídicas -, cuja inobservância acarretaria uma inevitável fratura entre o julgamento e a sociedade no seio da qual ele é realizado".
} 
em outros Estados-nações, em matéria penal ela se desenvolveu, nos últimos tempos, dando ênfase à persecução penal, sem, entretanto criar mecanismos que permitam à defesa a indispensável paridade de armas, não obstante de um arcabouço de normas internacionais que a asseguram.

O artigo 14 do Pacto Internacional sobre os Direitos Civis e Políticos, em seu item $3, b$, não dão margem a qualquer controvérsia, no sentido de que o direito de prova do acusado é amplo (desde que, obviamente, relevante e pertinente) e não se condiciona a qualquer limitação de ordem procedimental ou temporal.

Senão vejamos.

“Art. 14. (...)

3. Qualquer pessoa acusada de uma infração penal terá direito, em plena igualdade, pelo menos às seguintes garantias: (...)

b) A dispor do tempo e das facilidades necessárias para a preparação da defesa e a comunicar com um advogado da sua escolha”.

No mesmo sentido é o art. $8^{\circ}$ do Pacto de São José da Costa Rica, item 2, $c$ :

“Art. $8^{\circ} .(\ldots)$

2. Toda pessoa acusada de delito tem direito a que se presuma sua inocência enquanto não se comprove legalmente sua culpa. Durante o processo, toda pessoa tem direito, em plena igualdade, às seguintes garantias mínimas: (...)

c. concessão ao acusado do tempo e dos meios adequados para a preparação de sua defesa."

A eficácia da cooperação jurídica internacional, passa, necessariamente, pela construção de um arcabouço normativo, contendo instrumentos que viabilizem a cooperação 
mútua entre as diversas Nações. Entretanto, o que se tem evidenciado é uma ausência de uma rápida atuação dos entes estatais com a necessidade preeminente de se parametrizar os mecanismos de cooperação jurídica internacional em matéria penal, de modo a, sem engessála (já que esta deve ser o mais ampla possível), harmonizar princípios e regras universalmente consagrados quanto às provas, compatibilizando, na medida do possível, a compreensão dos Estados-Nações acerca da aplicabilidade dos direitos fundamentais, sem contudo, afetar as soberanias nacionais ${ }^{293}$.

Também mencionamos nossas preocupações com relação aos rumos em que o aprimoramento da dinâmica da produção das provas processuais, na prática, mostram-se dissociadas dos princípios universais do direito de cidadania e, sobretudo, a realidade atual que precisa ser modificada o quanto antes, no que concerne à participação do acusado na busca da verdade dos fatos na via cooperacional, em igualdade de condições com as instituições acusadoras, princípios esses expressamente tratados nos pactos internacionais supra-aludidos.

Essa preocupação sobreleva-se em relação à globalização, situação bem consolidada por Antonio Scarance Fernandes:

“ Essa característica de internacionalidade aliada à intensa proliferação desses crimes levou os países, em Convenções Internacionais, a buscar harmonizar normas penais e processuais penais, como, por exemplo, aconteceu com a Convenção Internacional sobre o Tráfico de Entorpecentes de Viena, referendada pelo Congresso Nacional, pelo Decreto Legislativo ${ }^{a}$ 162, de 14 de junho de 1991.

Em linhas gerais, no que se refere ao processo penal, os principais reflexos do acolhimento dessas Convenções no direito brasileiro foram, entre outros, os seguintes: maior rigor na prisão das pessoas envolvidas e, principalmente, a adoção de medidas tendentes a recuperar os bens obtidos com as práticas criminosas, admitindo-se,

\footnotetext{
${ }^{293}$ Ver BECHARA, Fábio Ramazzini. op. cit. e ABADE, Denise Neves, op. cit.
} 
até mesmo, a atribuição do ônus de provar a licitude da origem dos bens do acusado." 294

Com efeito, diante da realidade do mundo moderno e altamente tecnológico, tornou-se inevitável que, dentre as atuais diretrizes que caracterizam as relações entre as nações e do novo contexto político de atuação da persecução penal, a cooperação internacional para o combate às atividades criminosas encontrasse um campo amplo, em especial, diante das novas formas de capitalismo, com "concentração e volatilidade dos capitais transnacionais" 295 e o incremento impetuoso da criminalidade econômica e organizada.

Diante desta nova realidade exsurge a necessidade de uma análise mais profunda dos mecanismos da cooperação internacional em matéria penal e de seus reflexos no âmbito da prova, em especial, no que se refere à sua admissibilidade, no processo penal brasileiro.

No entanto, como já se teve oportunidade de abordar, o auxílio mútuo entre os países, não pode de forma alguma, comprometer princípios fundamentais do indivíduo, aos quais, por sua vez, perpassa a observância ao direito da adequada metodologia da prova ${ }^{296}$.

Propõe-se, portanto, que a cooperação internacional para combate das atividades criminosas seja estabelecida, pari passu, com uma padronização mais eficiente dos meios de defesa do acusado, notadamente com relação à participação do mesmo nos mecanismos

\footnotetext{
${ }^{294}$ FERNANDES, Antonio Scarance. O Processo Penal Internacional, in Direito Internacional, Humanismo e Globalidade, p. 178/179. Segundo o autor "Com a globalização e o forte intercâmbio entre os países, houve também a regionalização ou internacionalização de alguns crimes, o que exigirá uma evolução no sentido de maior colaboração entre os Estados para maior eficiência no combate a essa criminalidade. Enquadram-se nesse perfil de crimes transnacionais os crimes de tráfico nas suas mais diversas modalidades - tráfico de entorpecentes, tráfico de armas, tráfico de pessoas e tráfico de animais -, o crime de lavagem de dinheiro, o crime organizado, os crimes relacionados à corrupção de funcionários públicos estrangeiros ligados a transações comerciais internacionais e os crimes praticados pelo uso da informática, principalmente por meio da internet".

${ }^{295}$ SILVA FRANCO, Alberto da. Globalização e Criminalidade dos Poderosos, p. 241. Esclarece o autor: "Desta forma, grande concentração de capitais, mobilidade acelerada desse capitais e generalização célere da comunicação constituem o tripé do novo modelo capitalista gerador de um poder econômico global, sem possibilidade de controle por parte do poder político nacional".

${ }^{296}$ FERNANDES, Antonio Scarance. O equilíbrio entre a eficiência e o garantismo e o crime organizado, in Revista Brasileira de Ciências Criminais 70, São Paulo: RT, 2008, janeiro-fevereiro de 2008 - ano 16, p. 231. "Entre as tendências contemporâneas do processo penal, um vem se manifestando de forma intensa, a que busca o equilíbrio entre a exigência de assegurar ao investigado, ao acusado e ao condenado a aplicação de garantias fundamentais do devido processo legal e a maior eficiência do sistema persecutório para a segurança social".
} 
processuais que digam respeito à produção de provas, o que certamente, imporá um aprimoramento na elaboração normativa dos tratados internacionais de cooperação.

Cabe salientar, que os acordos de cooperação em matéria criminal, devem levar em consideração, também, os princípios que repudiam a utilização das provas ilícitas e ilegítimas.

O anseio pela almejada celeridade processual não justifica a rápida conclusão do processo com desrespeito aos demais direitos inerentes ao justo processo. Os problemas da morosidade do processo não é novo, e é discutido em todas as nações.

De fato, no âmbito da ação do Conselho da Europa, dando origem a diversas resoluções e recomendações com objetivo de melhorar o funcionamento da justiça e aumentar a sua celeridade. Tendo sido criada a "European Commission for the Efficiency of Justice (CEPEJ), cujo objetivo é acompanhar e auxiliar os Estados-membros no melhoramento do funcionamento dos sistemas de administração da justiça, designadamente o combate à morosidade processual”297. No âmbito da Convenção Americana de Direitos Humanos, a problemática da morosidade do processo penal também é bastante discutida, sendo importante destacar, a título de exemplo, o caso 12.051 de 2008, que originou a Lei Maria da Penha.

Destarte, como assentado por HASSEMER:

“As normas do processo são quase opostas a uma 'medida técnica'; a disposição é uma cópia rara e pura do princípio da proporcionalidade. É a garantia de uma proteção estável aos direitos fundamentais. O mandamento da supressão minimiza os efeitos da intervenção constitucional por intermédio de uma concretização do princípio da necessidade." 298.

\footnotetext{
${ }^{297}$ PINTO, Ana Luísa. A celeridade no processo penal: o direito à decisão em prazo razoável, p. 14. Prossegue o autor: "Apesar dos esforços desenvolvidos a nível nacional e internacional, o problema da morosidade processual generalizou-se pela Europa, como evidenciam as condenações do Tribunal Europeu dos Direitos do Homem (TEDH). Entre os Estados condenados por violação do direito à decisão em prazo razoável no processo penal contam-se, desigualmente, a Alemanha, a Áustria, a França, a Holanda, a Turquia e sobretudo a Itália. Uma justiça tardia não é verdadeira justiça. Por isso concordamos com quem afirma que a procura de uma justiça certeira, eficaz e rápida é um dos principais desafios que actualmente se colocam ao Estado de direito". Ver também Lopes Jr, Ary e Badaró, Gustavo Henrique, Direito ao Processo Penal no Prazo Razoável, p. 131.

${ }^{298}$ HASSEMER, Winfried. Direito Penal Libertário, p. 133. Conforme o autor: "A garantia processual e a proteção dos envolvidos são objetivos do processo, os quais somente em um conceito otimizado podem ser
} 
O aprimoramento dos meios de defesas do acusado no processo penal passa, necessariamente, pela harmonização dos princípios de produção das provas nos diversos Estados soberanos.

Fábio Ramazzini Bechara elucida que "A diversidade entre os sistemas probatórios é um dos principais problemas que afetam a eficácia da prova produzida no exterior, uma vez que a diversidade do procedimento probatório pode comprometer a sua capacidade de demonstração",299.

E prossegue: "Na realidade, a concepção do procedimento como parâmetro é pautada pelo padrão normativo universal dos direitos humanos, no sentido que garantias que incidem sobre a atividade probatória" 300 .

Tem-se, pois, uma cadeia lógica de pensamentos, a saber:

$1^{\circ}$ ) A produção de prova no processo penal (e até mesmo antes da instauração deste) deve ser considerada, também, em relação à obtenção da verdade atingível dos fatos e inafastavelmente aliada ao espírito do contraditório, em convergência ao direito de defesa do réu;

$\left.2^{\circ}\right) \mathrm{O}$ processo penal só pode ser admitido como regular e justo, se nele for obedecida uma correta metodologia probatória, nos moldes que expusemos anteriormente;

$3^{\circ}$ ) O conjunto probatório, por sua vez, deve ser considerado em relação aos fatos apurados e obedecido, como se disse antes, o amplo direito de defesa do acusado, por ser um imperativo de direitos humanos; e

$4^{\circ}$ ) No campo da cooperação internacional, por fim, é dever das nações não só estabelecerem políticas de combate às atividades criminosas, mas também, paralelamente a isso, promover uma padronização sistêmica quanto aos procedimentos processuais e meios de provas e de obtenção de provas, sempre, em última análise, na verificação da verdade

perseguidos simultaneamente. Eles se encontram, tipicamente, em uma relação de tensão (igualmente como na situação entre formalidade judicial e eficiência) e como se pode comprovar, por todo o Código de Processo Penal, o que se dá a um, deve-se retirar do outro. Quem tem ambos os objetivos, deve então definir como imagina uma otimização, isto é, quando de um e do outro".

${ }^{299}$ BECHARA, Fábio Ramazzini. Cooperação Jurídica Internacional em Matéria Penal, São Paulo: Malheiros, 2009, p. 81

${ }^{300}$ BECHARA, Fábio Ramazzini. Cooperação Jurídic (...), op. cit., p. 81 
atingível, obedecendo-se o direito de ampla defesa, o contraditório e a paridade de armas no âmbito probatório.

Tem-se sustentado ao longo dos últimos anos, acerca da necessidade de um modelo mais universal do processo judicial. Parece, de fato, uma tendência inevitável, ante a globalização.

Entretanto, os problemas de implementação e eficácia das provas produzidas por meio da cooperação jurídica internacional não residem somente na falta de uma sistematização legal, mas também no desconhecimento dos operadores do direito quanto aos mecanismos existentes e a sua tramitação. Especialmente no que se refere à defesa, que na maioria das vezes nem sequer é informada da existência de um pedido cooperacional, não podendo se pronunciar sobre sua necessidade e relevância, ou ainda participar de sua produção. Ademais, como a cooperação é vista como ato entre Estados, não se consideram os particulares como atores no processo, impedindo-se a defesa de produzir as provas por esta via $^{301}$

Não se há de olvidar, outrossim, a clássicos motivos utilizados pelos Estados para não cooperar, como a soberania, ordem pública, inexistência de dupla incriminação, crime político, crime militar, dentre outras.

Não obstante as dificuldades no processamento da cooperação jurídica internacional em matéria penal ela é uma realidade da sociedade atual, está posta, mas não pode vir a tornar-se um fim em si mesma ${ }^{302}$.

Ora, se no que concerne à efetiva obtenção da verdade atingível, a produção de provas no processo penal apresenta, como se abordou anteriormente, um aspecto social, tal circunstância não está dissociada, no plano subjetivo, de ser um direito da parte essa obtenção.

Não se pode deixar de transcrever aqui, a observação de C.J.A. Mittermaier, em sua obra Tratado da Prova:

\footnotetext{
${ }^{301}$ SOUZA, Carolina de, “A defesa na cooperação jurídica internacional - reflexões preliminares”, in Boletim do IBCCRIM 214 - setembro/2010.

${ }^{302}$ SOUZA, Carolina de, “A defesa na cooperação jurídica internacional - reflexões preliminares”, in Boletim do IBCCRIM 214 - setembro/2010
} 
"O legislador tem muitas vezes tentado, para satisfazer as opiniões mais contrarias, combinas as formulas que decorrem de cada uma dellas; e, por isso é que se o vio, na esperança de que tal mistura sahiria dupla vantagem: dar a juizes regulares o direito de sentenciar, sem que uma theoria legal da prova dirija suas apreciações, e sem que sejão obrigados a dar os motivos de suas convicções, que lhes fôrão deixadas inteiramente livres.(...)Apressemo-nos, porém, a dizer que uma tal combinação não póde satisfazer os votos da justiça; não reproduz as vantagens da jurisdição regular baseada na theoria legal; e está longe de fazer calarem-se as vozes que se levantão em favor do jury. A natureza hybrida do systema produz desde logo funestas consequencias" (tradução com a grafia da época)." 303

Consequentemente, mais uma condição se estabelece na matéria ora abordada: a produção de provas pressupõe a chamada paridade de $\operatorname{armas}^{304}$.

Tal raciocínio não está circunscrito à ideia de oportunidade quanto à produção ou contraposição de alguma prova, nem, tampouco, aos ritos dessa oportunidade.

É muito mais que isso. A ideia de paridade de armas está intimamente relacionada a um equilíbrio sistêmico na produção das provas e da consequente obtenção da verdade real $^{305}$.

\footnotetext{
${ }^{303}$ MITTERMAIER, C.J.A. Tratado da Prova em Matéria Criminal, p. 150
}

${ }^{304}$ A propósito do conceito da expressão, magistral o raciocínio desencadeado por TUCCI, Rogério Lauria. Direitos e Garantias Individuais no Processo Penal Brasileiro, p. 144, ao comentar sobre o direito constitucional do cidadão do devido processo legal: "Para que isso aconteça, tornam-se imprescindíveis, outrossim, a par do contraditório indispositivo, a concessão, ao acusado, 'em geral', da possibilidade de ampla defesa, com todos os meios e recursos a ela inerentes (sobretudo a técnica, realizada, como visto, por um profissional dotado de conhecimento jurídico específico), numa autêntica paridade de armas, efetivada no contexto da atuação dos agentes estatais da persecutio criminis e da defensiva; e a diversificação da ação do Ministério Público, dada a inafastabilidade de conjugação de esforços, de colaboração com o órgão jurisdicional, no descobrimento da verdade material, ou atingível".

${ }^{305}$ Ou atingível, cf. TUCCI, Rogério Lauria, op. cit., p. 142: "Ora, a fim de que a verdade material, ou atingivel, desponte, em sua inteireza, torna-se imprescindivel, para a devida perquirição, a conjugação de esforços de todos quantos participem, desde a sua instauração, da 'persecutio criminis', a saber: a autoridade policial, ou outra, da Administração Pública ou dos demais Poderes - Legislativo ou Judiciário -, encarregada da informatio delicti; e seus agentes; juiz, órgão do Ministério Público (e o assistente deste), ou querelante, e imputado. E, como já exaustivamente asseverado, que se confira, aos interessados e sujeitos parciais, as 
Cabe considera que, por via de consequência, o contraditório não se estabelece apenas no âmbito das alegações, mas também nas condições para a obtenção da verdade atingível. A dinâmica da produção de provas deve estar norteada na profundidade e amplitude do alcance para sua produção ou impugnação.

E, se por profundidade estamos nos referindo ao próprio âmago da natureza da prova, por amplitude queremos dizer que cabe ao Poder Judiciário assegurar ao réu no processo penal o acesso incondicional (pertinência e relevância) ao direito de prova ou impugnação desta, independentemente do local de sua produção.

Essa é uma preocupação global. Paolo Tonini, ao comentar o inciso 4 do art. 111 do Constituição Italiana, mais uma vez nos socorre com a Doutrina Italiana para exteriorização de nosso ponto de vista:

“O contraditório, em sentido objetivo, é estabelecido no início do inciso 4 e se refere ao contraditório 'na formação da prova'. É uma expressão que consagra o contraditório 'na formação da prova'. A verdadeira prova não é aquela que se obtém sob sigilo, por meio de pressões unilaterais, mas aquela cuja formação ocorre de modo dialético. A inovação está no fato de o princípio não ser afirmado de maneira absoluta, como havia feito a Comissão bicameral, quando, no art. 130 do projeto, fazia referência à oralidade, à imediatidade e ao contraditório sem estabelecer qualquer exceção." 306

Assim, nessa esteira, um exemplo eloquente dessa nossa sustentação é a produção de oitiva de testemunha no exterior.

Ora, se é possível, por exemplo, ao Ministério Público, arrolar e requerer sua oitiva, bem como formular as perguntas para que a mesma seja ouvida por testemunha por rogatória, bem ver cumprida a providência solicitada, o mesmo direito tem - ou deveria ter - o

mesmas, idênticas, possibilidades de evidenciá-la, em estrita colaboração com outros agentes estatais incumbidos da concretização da persecução, ou processo penal, e, especialmente, com o órgão jurisdional"

${ }^{306}$ TONINI, Paolo, op. cit., p. 27. 
acusado do processo penal. O que, em alguns casos, em razão do sistema adversarial não é possibilitado à defesa (como no caso dos EUA).

A matéria acerca da prova no processo penal, tangencia o Direito Internacional, no que diz a seu espírito, sistematização e positivação.

Essa interação, ao contrário do que pode parecer em um primeiro momento, diz menos respeito à metodologia dos meios de provas, do que à sua produção no processo, propriamente dito.

É, deveras, um contrassenso.

Em uma época em que as comunicações são virtualmente instantâneas, a facilidade para obtenção de informações chega a ter um nível assustadoramente espantoso e as mídias à disposição mostram-se as mais variadas, torna-se injustificável a inexistência de mecanismos eficazes, que, não obstante, os métodos para produção de provas judiciais em sede global ainda estejam tão longe de atender satisfatoriamente o processo penal e, pior, em detrimento do direito à ampla defesa, como restará ponderado.

Salta à evidência, pois, que se trata de questão de política judicial e não limitação de ordem tecnológica.

\subsection{Considerações sobre a cooperação jurídica em matéria penal na Europa e na América Latina}

Feitas estas considerações, pode-se passar à análise dos sistemas regionais de cooperação jurídica internacional em matéria penal.

A União Europeia ${ }^{307}$ está bem mais evoluída em termos de compatibilização das legislações, de modo a propiciar a efetividade da cooperação jurídica internacional.

\footnotetext{
${ }^{307}$ Ver http://pt.wikipedia.org/wiki/Uni\%C3\%A3o Europeia. “União Europeia (UE) é uma união económica e política de 27 Estados-membros independentes que estão localizados principalmente na Europa. (...) O Tratado de Maastricht estabeleceu a União Europeia com o seu nome atual em 1993. A última alteração ao fundamento constitucional da UE, o Tratado de Lisboa, entrou em vigor em 2009. A UE opera através de um sistema híbrido de instituições supranacionais independentes e de decisões intergovernamentais feitas e negociadas pelos Estados-membros. As mais importantes instituições da UE são a Comissão Europeia, o Conselho da União Europeia, o Conselho Europeu, o Tribunal de Justiça da União Europeia e o Banco Central Europeu. O Parlamento Europeu é eleito a cada cinco anos pelos cidadãos da UE".
} 
As comunidades europeias foram criadas, com objetivo de "promover a paz, os seus valores e o bem-estar dos seus povos", proporcionando:

“aos seus cidadãos um espaço de liberdade, segurança e justiça sem fronteiras internas, em que seja assegurada a livre circulação de pessoas, em conjugação com medidas adequadas em matéria de controles na fronteira externa, de asilo e imigração, bem como de prevenção da criminalidade e combate a este fenómeno." 308

No desenvolvimento deste objetivo, os povos da Europa estabeleceram entre si uma união cada vez mais estreita, derrubando fronteiras, de modo a viabilizar maior integração econômica.

Conforme estabelece o preâmbulo da Carta de Direitos Fundamentais da União Europeia $^{309}$ :

\footnotetext{
${ }^{308}$ Ver artigo $2^{\text {a }}$ do Tratado da Convenção Europeia, atual artigo $3^{\circ}$, do Tratado da Comunidade europeia, " 1 . A União tem por objectivo promover a paz, os seus valores e o bem-estar dos seus povos; 2. A União proporciona aos seus cidadãos um espaço de liberdade, segurança e justiça sem fronteiras internas, em que seja assegurada a livre circulação de pessoas, em conjugação com medidas adequadas em matéria de controlos na fronteira externa, de asilo e imigração, bem como de prevenção da criminalidade e combate a este fenómeno; 3. A União estabelece um mercado interno. Empenha-se no desenvolvimento sustentável da Europa, assente num crescimento económico equilibrado e na estabilidade dos preços, numa economia social de mercado altamente competitiva que tenha como meta o pleno emprego e o progresso social, e num elevado nível de proteç̧ão e de melhoramento da qualidade do ambiente. A União fomenta o progresso científico e tecnológico; A União combate a exclusão social e as discriminações e promove a justiça e a protecção sociais, a igualdade entre homens e mulheres, a solidariedade entre as geraçães e a protecção dos direitos da criança; A União promove a coesão económica, social e territorial, e a solidariedade entre os Estados-Membros. A União respeita a riqueza da sua diversidade cultural e linguística e vela pela salvaguarda e pelo desenvolvimento do património cultural europeu; 4. A União estabelece uma união económica e monetária cuja moeda é o euro; 5. Nas suas relações com o resto do mundo, a União afirma e promove os seus valores e interesses e contribui para a protecção dos seus cidadãos. Contribui para a paz, a segurança, o desenvolvimento sustentável do planeta, a solidariedade e o respeito mútuo entre os povos, o comércio livre e equitativo, a erradicação da pobreza e a protecção dos direitos do Homem, em especial os da criança, bem como para a rigorosa observância e o desenvolvimento do direito internacional, incluindo o respeito dos princípios da Carta das Nações Unidas; 6. A União prossegue os seus objectivos pelos meios adequados, em função das competências que lhe são atribuídas nos Tratados".
}

${ }^{309}$ MOREIRA, Vital aula ministrada no Curso de Direitos Fundamentais, promovido pelo IBCCRIM e pela Universidade de Coimbra, no ano de 2012. "Finalmente, o Tratado de Lisboa (2007), desta vez com sucesso, conferiu força jurídica à Carta, embora esta se tenha mantido como texto autônomo, não inserido nos tratados, figurando como 'protocolo anexo', ainda que com o mesmo valor jurídico daqueles. Todavia, ainda que a Carta se tenha tornado 'direito constitucional' da EU, a verdade é que alguns Estados-membros (Reino Unido e Polónia) fizeram declarações de 'opting out' em relação a alguns dos seus aspectos, nos termos de declaração anexa ao Tratado de Lisboa. Embora com essa reserva, a CDFUE passava finalmente a fazer parte do 'direto primário' (constitucional) da EU. (...) Não é necessário sublinhar a importância simbólica e jurídica da 
“A União contribuiu para a preservação e o desenvolvimento destes valores comuns, no respeito pela diversidade das culturas e tradições dos povos da Europa, bem como da identidade nacional, regional e local; procura promover um desenvolvimento equilibrado e duradouro e assegura a livre circulação das pessoas, dos serviços, dos bens e dos capitais, bem como a liberdade de estabelecimento."

Evidentemente que esta facilitação de circulação de mercadorias e pessoas ocasionou reflexos na forma da criminalidade, que passou a ultrapassar as fronteiras nacionais, com maior intensidade.

Diante da crescente necessidade de se garantir uma maior eficácia na persecução penal, de modo a propiciar maior segurança pública, a União Europeia, pautando-se pelo princípio do reconhecimento mútuo de decisões e resoluções judiciais, criou mecanismos de cooperação jurídica e harmonização das legislações ${ }^{310}$.

Nos dizeres de Bechara, buscou-se atingir dois objetivos: "assegurar que os criminosos não tenham refúgio seguro em outro Estado, bem como que as decisões ou resoluções adotadas num Estado-Membro surtam efeitos em toda a União Europeia., ${ }^{311}$

Souza Silva esclarece que a Comunidade Europeia tornou-se realidade graças:

CDFUE. Para começar, ela constitui um marca na história universal do reconhecimento e proteção dos direitos humanos. Até agora todas as declarações de direitos eram declarações nacionais ou internacionais destinadas a vincular os Estados nacionais. Com a CDFUE, pela primeira vez, uma organização supranacional dota-se de um 'bil of rights' que a vincula diretamente e que defende os seus cidadãos e residentes contra os seus próprios atos políticos, legislativos e administrativos. De facto, como se verá, os primeiro destinatários da Carta são as instituições, órgãos e agências da União, na sua atividade legislativa ou administrativa (embora a Carta também vincule os Estados-membros quando implementem atos da EU)".

${ }^{310}$ Ver http://pt.wikipedia.org/wiki/Uni\%C3\%A3o_Europeia “A UE tem desenvolvido um mercado comum através de um sistema padronizado de leis que se aplicam a todos os Estados-membros. No Espaço Schengen (que inclui membros e não membros da UE) os controlos de passaporte foram abolidos. As políticas da UE têm por objetivo assegurar a livre circulação de pessoas, bens, serviços e capitais, legislar assuntos comuns na justiça e manter políticas comuns de comércio, agricultura, pesca e desenvolvimento regional. A união monetária, a Zona Euro, foi criada em 1999 e é atualmente composta por 17 Estados-membros. Através da Política Externa e de Segurança Comum, a UE desenvolveu um papel limitado nas relações externas e de defesa. Missões diplomáticas permanentes foram estabelecidas em todo o mundo e a UE é representada nas Nações Unidas, na Organização Mundial do Comércio (OMC), no G8 e no G-20”".

311 BeChARA, Fábio Ramazzini, Cooperação jurídica internacional em matéria penal. Eficácia da prova produzida no exterior, São Paulo: Saraiva, 2011, p. 174. 
"a uma engenhosa e articulada estrutura jurídico- política que lhe serve de sustentáculo A arquitetura jurídica constituída, basicamente pelo Direito Comunitário e seu sistema jurisdicional, ganhou vida com o objetivo de regulamentar as relações travadas no âmbito da União, superando os ambiciosos desafios emergentes - principalmente aqueles decorrentes de sua inserção nos ordenamentos jurídicos dos Estados-membros - e com disposição de solucionar a chuva ácida de entraves que significa um processo de integração dessa magnitude",312.

A harmonização das leis penais nacionais da União Europeia operou-se levando em conta os interesses econômicos dos Estados nacionais e supranacionais e a questão da segurança interna, bem como a complexa incidência da legislação econômica comunitária no ordenamento jurídico-penal dos Estados-Membros, não instruído ou sequer mencionado nos $\operatorname{tratados}^{313}$.

Segundo Machado, "os distintos temas relacionados à rubrica 'espaço comum europeu', outrora atribuição exclusiva da cooperação intragovernamental, encontram-se hoje compartilhados, de acordo com a matéria, entre o Tratado da União Européia (TUE) e o Tratado da Comunidade Européia (TCE)." 314.

Não se há de negar que a gama de cooperação intergovernamental na União Européia é grande e mais célere, abrangendo desde a produção de provas até o mandado de detenção europeu (que substituiu o lento procedimento de extradição), com ampla interrelação direta entre as polícias dos estados $\left(\right.$ Europol $\left.^{315}\right)$ e entre os órgãos do poder judiciário

\footnotetext{
${ }^{312}$ SOUZA SILVA, Karine de. Direito da Comunidade Européia. Fontes, Princípios e Procedimentos, Ijuí: Unijuí, 2005, p.37.

${ }^{313}$ MACHADO, Maíra Rocha. Internacionalização do direito penal. A gestão de problemas internacionais por meio do crime e da pena, Sã Paulo: 34 Ltda./ Edsp, 2004, p. 60.

${ }^{314}$ MACHADO, Maíra Rocha. Internacionalização ..., op. cit., p. 60. Prossegue a autora: “Com o advento do trato de Amsterdã, os temas relacionados à imigração, às políticas de vistos e de asilo foram 'comunitarizados'; isto é, deixaram de pertencer à esfera da cooperação intergovernamental para serem submetidos aos procedimentos e mecanismos do direito comunitário, com algumas modificações significativas. Dessa forma, imigração, vistos e asilo - sob a égide da Comunidade Européia - e cooperação de cunho policial e judicial em matéria penal - no campo da cooperação intergovernamental - convergem para a edificação de um espaço de liberdade, segurança e justiça' (art. 29 TUE e art. 61 TCE)”.'

${ }^{315}$ http://pt.wikipedia.org/wiki/Europol. "Europol é a abreviatura utilizada para designar o Serviço Europeu de Polícia. A Europol iniciou as suas actividades em 1 de Julho de $\underline{1999}$. Situa-se em Haia, nos Países Baixos. A Europol é um serviço Europeu de polícia, incumbido do tratamento e intercâmbio de informação criminal.(...) $O$
} 
(Eurojus ${ }^{316}$ ). Há um grande gama de cooperação intergovenamental na Comunidade Europeia, baseada na confiança e reconhecimento mútuo em matéria de produção de prova.

O conselho da Europa em Tampere, em outubro de 1999, concedeu significativa importância ao princípio do reconhecimento mútuo, reconhecendo-se que este princípio constitui ponto basilar da cooperação judicial na União ${ }^{317}$.

Conforme se depreende do programa de medidas para implementação do princípio do reconhecimento mútuo, de decisões em matéria penal:

"O reconhecimento mútuo assume pois formas diversas, devendo ser procurado em todas as fases do processo penal, antes, depois ou após a sentença, mas as suas regras diferem consoante a natureza da decisão ou da pena infligida." 318 .

seu objectivo consiste em melhorar a eficácia e a cooperação entre os Estados Membros no domínio da prevenção e do combate a formas graves de criminalidade organizada de dimensão internacional. A Europol tem por objectivo melhorar a eficácia e a cooperação entre os serviços competentes dos Estados Membros da UE no domínio da prevenção e combate ao crime organizado nas seguintes áreas: Criminalidade relacionada com tráfico ilícito de estupefacientes; Terrorismo; Atentados à vida; à integridade física ou à liberdade das pessoas; incluindo imigração clandestina; tráfico de seres humanos; rapto; sequestro; pornografia infantil; tráfico ilícito de órgãos e tecidos humanos, assim como racismo e xenofobia. Atentados ao património e aos bens públicos; incluindo fraude; roubo organizado; extorsão; tráfico ilícito de bens culturais; contrafacção e mercadorias - pirataria; falsificação de moeda e de outros meios de pagamento; falsificação de documentos administrativos e respectivo tráfico, criminalidade informática e corrupção; Comércio ilegal e atentados ao ambiente; incluindo tráfico ilícito de armas; criminalidade relacionada com material nuclear e radioactivo; tráfico ilícito de espécies ameaçadas de fauna e flora; crimes contra o ambiente e tráfico de substâncias hormonais e outros factores de crescimento;Actividades ilícitas de branqueamento de capitais provenientes dos crimes supramencionados".

${ }^{316}$ http://eurojust.europa.eu/Pages/languages/pt.aspx. "A Eurojust foi instituída pela Decisão do Conselho 2002/187/JAI, alterada pela Decisão do Conselho 2009/426/JAI, de 16 de Dezembro de 2008. A missão da Eurojust é reforçar a eficácia das autoridades nacionais responsáveis pela investigação e pelo exercício da acção penal na luta contra as formas graves de criminalidade transfronteiriça e a criminalidade organizada, bem como submeter os criminosos a julgamento de forma célere e eficaz. O objectivo que a Eurojust se propõe alcançar é o de desempenhar um papel principal e de ser o centro de peritos a nível judiciário com vista a uma acção efectiva contra a criminalidade organizada transnacional na União Europeia. A Eurojust foi instituída em 2002 para apoiar e reforçar a coordenação e a cooperação entre as autoridades nacionais na luta contra as formas de criminalidade grave transnacional que afectam a União Europeia".

${ }^{317}$ Ver. Conclusão presidencial $n^{\circ}$ s 33 e 35 do Conselho da União Europeia em Tampere. Disponível em www.consilium.europa.eu/eudocs/pressData/en/ec/00200-r1.

${ }^{318}$ Ver jornal oficial n ${ }^{\circ} \mathrm{C} 012$ de 15/01/2001 p. 0010-0022. “Em cada um destes domínios, a dimensão do reconhecimento mútuo depende em grande medida da existência e do conteúdo de determinados parâmetros que condicionam a eficácia do exercício, parâmetros esses que foram identificados ao longo dos trabalhos desenvolvidos no Conselho, em especial pela delegação do Reino Unido. Esses parâmetros são os seguintes:- $O$ alcance geral, ou limitado a determinadas infracções, da medida prevista. Um determinado número de medidas de aplicação do reconhecimento mútuo podem ser limitadas às infracções graves;- A manutenção ou a supressão da exigência da dupla incriminação como condição do reconhecimento;- $\quad$ Os mecanismos de 
Note-se que o direito comunitário, como assevera Losano, tem seus próprios instrumentos legislativos:

"Os regulamentos (ou, na CECA, as 'decisões gerais') criam diretamente direitos e obrigações para os Estados-membros e para as pessoas físicas e jurídicas englobadas nos respectivos âmbitos: são, portanto, comparáveis à lei de direito nacional. Ao contrário, as diretivas são endereçadas apenas aos Estados-membros, que devem traduzi-las em normas de direito interno: esse fato as aproxima das normas internacionais, se bem que em alguns casos tenha ocorrido de fato - a aplicação direta também das diretivas. Enquanto os regulamentos e as diretivas têm alcance geral, os pareceres e as recomendações não têm caráter vinculante. Esta acumulação normativa uniu-se sem dificuldades a normativa de cada um dos Estados-membros." 319 .

Ademais, a Comunidade Europeia possui uma Carta de Direitos Fundamentais que, além de refirmar a proteção dos direitos do homem e das liberdades fundamentais, institui que "o gozo destes direitos implicam responsabilidades de deveres, tanto para com as outras pessoas individualmente consideradas, como para a comunidade humana e as gerações futuras." 320 .

Dentre outros direitos fundamentais, a carta consagra o direito: a dignidade do ser humano (art. 1); à vida (art. 2); à integridade do ser humano (art. 3); a proibição de tortura e dos tratos ou penas desumanas ou degradantes (art. 4); à liberdade e à segurança (art. 6); a proteção de dados pessoais (art. 8); a liberdade de pensamento, de consciência e de religião proteção dos direitos de terceiros, das vítimas e dos suspeitos; -

A definição de normas mínimas comuns necessárias para facilitar a aplicação do princípio do reconhecimento mútuo, notadamente em matéria de competência e jurisdições;- $\quad$ A execução direta ou indirecta da decisão, e a definição e âmbito do eventual processo de validação;- A determinação e o âmbito dos motivos de recusa do reconhecimento com base na soberania ou noutros interesses essenciais do Estado requerido, ou relacionados com a legalidade; - O regime de responsabilidade dos Estados no caso de arquivamento do processo, ilibação ou absolvição”.

${ }^{319}$ LOSANO, Mario G. "Uma carta fundamental: para a União Européia: Constituição ou Tratado?" in Mesquita Benevides, Maria Victoria de, BerCovici, Gilberto e Melo, Claudineu de (org.), Direitos humanos, democracia e república. Homenagem a Fábio Konder Comparato, São Paulo: Quartier Latin, 2009, p. 757.

${ }^{320}$ Ver preâmbulo da Carta de Direitos Fundamentais da União Europeia. 
(art. 10); a liberdade de expressão e de informação (art. 11); de propriedade (art. 17); de petição (art. 44); a ação e a um tribunal imparcial (art. 47); a presunção de inocência, os direitos de defesa (art. 48); a legalidade e proporcionalidade dos delitos e das penas (art. 49); do ne bis in idem (art. 50).

A cooperação jurídica interestatal no Mercado Comum Europeu deve se pautar pelo respeito a estes direitos consagrados pela Carta da União Europeia.

Entretanto, na prática, verifica-se que inexiste um consenso quanto à forma de aplicação dos direitos fundamentais dos Estados-Membros, tanto que ainda é discutida pelo Conselho da Europa a parametrização quanto ao direito de acesso a advogado de suspeitos e acusados, direito este que influi na admissibilidade da prova, existindo reticências de alguns Estados-membros.

A título de exemplo veja os principais resultados da reunião do conselho, ocorrida em Bruxelas, em junho de 2012.

“O Conselho definiu uma orientação geral (10908/12) sobre uma proposta de diretiva relativa ao direito de acesso a um advogado no âmbito dos processos penais e ao direito de comunicação após a detenção. Embora alguns Estados-Membros ainda tenham preocupações no que respeita a alguns pontos do texto, ficou acordado, de uma maneira geral, que tinha chegado a altura de encetar negociações com o Parlamento Europeu a fim de chegar a acordo sobre o texto final da diretiva.

A orientação geral surge precisamente um ano após a Comissão ter apresentado a sua proposta (8 de junho de 2011). Este período relativamente longo de deliberações pode ser explicado pela natureza sensível do assunto do dossiê: a diretiva visa aproximar as legislações dos Estados-Membros num domínio em que existem diferenças substanciais entre os sistemas nacionais e em que os EstadosMembros estão em desacordo sobre a interpretação da jurisprudência do Tribunal Europeu dos Direitos do Homem. 
Quando a Comissão apresentou a sua proposta, foi alvo de críticas por parte dos Estados-Membros. Para responder às preocupações, o texto da proposta foi consideravelmente reformulado. $\mathrm{O}$ texto atual procura conciliar as posições de todos os Estados-Membros. O elemento mais inovador do texto consta do artigo 3.o, n. ${ }^{\circ} 4$, que faz uma distinção em termos dos esforços que deverão ser envidados por um EstadoMembro no que diz respeito ao direito de acesso a um advogado. Em todos os casos em que a pessoa suspeita ou acusada é privada de liberdade, os Estados-Membros deverão tomar as disposições necessárias para assegurar que essa pessoa suspeita ou acusada esteja em condições de exercer efetivamente o seu direito de acesso a um advogado; nos casos em que um suspeito ou acusado esteja livre (não seja privado de liberdade), os Estados-Membros não deverão impedir essa pessoa de exercer efetivamente o seu direito de acesso a um advogado.

A diretiva proposta faz parte de um Roteiro sobre direitos processuais no âmbito de processos penais, aprovado pelo Conselho em novembro de $2009^{1}$, que inclui uma série de propostas destinadas a estabelecer normas mínimas comuns no tocante aos direitos que assistem aos suspeitos e pessoas acusadas no âmbito de processos penais.

O projeto de diretiva, na versão apresentada ao Conselho, trata, entre outros, dos seguintes aspetos (11497/11):

- o direito de acesso a um advogado por parte das pessoas suspeitas acusadas (quando e sob que condições);

- o princípio da confidencialidade das comunicações entre o advogado e a pessoa suspeita ou acusada;

- o direito da pessoa suspeita ou acusada que está privada de liberdade de comunicar com as autoridades consulares ou diplomáticas do seu País;

- a possibilidade de derrogar temporariamente a certos direitos em circunstancias excepcionais e unicamente por motivos imperiosos; 
- o direito, para as pessoas procuradas objeto de um mandado de detenção europeu, de terem acesso a um advogado no Estado de execução." 321

No campo das provas, imperioso se faz mencionar a existência do mandado europeu de obtenção de provas, que substituiu o sistema de assistência judicial em matéria penal, entre os Estados-Membros para obtenção de objetos, documentos e dados destinados a procedimentos penais $^{322}$.

A decisão-quadro 2008/978/JAI do Conselho, de 18 dezembro de 2008, regulamenta e traça diretrizes para a utilização do mandato europeu de obtenção de provas. Relevante citar, neste interim, alguns artigos desta decisão quadro:

“(7) O mandato europeu de obtenção de provas pode ser utilizado para obter objectos, documentos e dados para utilização no âmbito de processos penais para os quais esse mandado posse ser emitido. Pode

\footnotetext{
${ }^{321}$ www.consilium.europa.eu/uedocs/cms-data/doc. "A Comissão apresentou esta proposta em Julho de 2011 (11497/11) Os principais pontos a analisar no âmbito dos futuros trabalhos foram expostos num documento da Presidencia (15812/11): - o âmbito da directiva: embora alguns Estados-Membros considerem que o direito de acesso a um advogado deveria dar à pessoa suspeita ou acusada um direito, que deveria traduzir- se pela assistência efectiva de um advogado, outros prevêem um sistema diferente, segundo o qual o direito de acesso a um advogado não implica necessariamente que o suspeito ou acusado seja sistematicamente assistido por um advogado. No primeiro caso, a responsabilidade pelo exercício do direito de acesso a um advogado incumbe, pelo menos em parte, às autoridades públicas (perspectiva da garantia). Este sistema poderia ter consequências consideráveis em termos financeiros e processuais. No segundo caso, a responsabilidade passa a ser do suspeito ou do acusado (perspectiva da oportunidade). Esta abordagem poderia alargar consideravelmente o ambito de aplicação, fazendo do direito de acesso um princípio basilar, mesmo na fase inicial do processo, ainda que esse direito nem sempre seja exercido; - as situações em que deveria ser concedido o direito de acesso a um advogado: esta questão está estreitamente relacionada com a questão do âmbito de aplicação. Parece existir um amplo acordo quanto ao facto de este direito dever ser concedido pelo menos em todas as situações em que uma pessoa suspeita ou acusada é objecto de uma acção penal num tribunal, assim como quando é detida. Outras situações continuam a ser objecto de debate, como por exemplo quando uma pessoa é convidada a apresentarse espontaneamente num comissariado de polícia para ser interrogada, quando tenha sido detida na rua e convidada a responder às perguntas das autoridades responsáveis pela investigação ou em "actos processuais

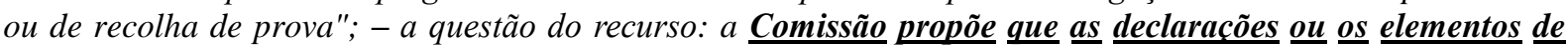

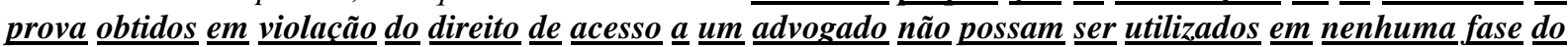
processo como elementos de prova contra a pessoa em causa, mantendo ao mesmo tempo um poder de apreciação quando a utilização desses elementos não venha prejudicar os direitos da defesa. A maior parte dos Estados-Membros referiu que não podia aceitar esta proposta e comunicou que não deveriam ser dadas quaisquer indicações aos juízes. Argumentam que a questão do valor a conceder a tais declarações deveria ser analisada por um tribunal competente em matéria penal". (realces nossos).

${ }^{322}$ Ver europa.eu/legislation_summaries/justice_freedom_security/judicial. "El exhorto europeo de obtención de pruebas sustituye al sistema de asistencia judicial en materia penal entre los Estados miembros para obtener objetos, documentos y datos destinados a procedimientos penales. Esta Decisión Marco determina los procedimientos y salvaguardias por los que los Estados miembros ejecutarán y emitirán exhortos de obtención de pruebas".
} 
tratar-se, por exemplo, de objectos, documentos, ou dados de terceiro, ou resultantes de buscas de locais, incluindo a busca domiciliária, de dados históricos sobre a utilização de serviços, incluindo transacções financeiras, de registros de declarações, interrogatórios e audições e de outros registros, incluindo os resultados de técnicas especiais de investigação. (...)

A definição de <busca ou apreensão> não deverá ser utilizada na execução de qualquer outro instrumento aplicável entre os Estados-Membros, designadamente a Convenção do Conselho da Europa de Auxílio Judiciário Mútuo em Matéria Penal, de 20 de abril de 1959, e os instrumentos que a complementarem.

Só deverá ser emitido um mandado europeu de obtenção de provas caso a obtenção dos objetos, documentos ou dados abrangidos pelo mandado seja necessária e proporcional para efeitos do processo penal ou outro em causa. Além disso, o mandado europeu de obtenção de provas só deverá ser emitido caso os objectos, documentos ou dados em questão possam ser obtidos ao abrigo do direito interno do Estado de emissão em casos comparáveis. A responsabilidade de assegurar o espeito destas condições deverá caber à autoridade de emissão. Os motivos de não reconhecimento ou não execução não deverão, pois, abranger essas matérias.

A autoridade de execução deverá recorrer aos meios menos intrusivos para obter objetos, documentos ou dados procurados.(..)

A autoridade de emissão deverá poder, caso o direito interno do Estado de emissão o preveja para transposição do artigo 12. ${ }^{\circ}$, solicitar à autoridade de execução que respeite determinados procedimentos e formalidades para se conformar a procedimentos legais ou administrativos que possam contribuir para que as provas pretendidas sejam admissíveis no Estado de execução, nomeadamente a autenticação oficial de um documento, a presença de um representante do Estado de emissão ou o registro de horas e datas para 
criar uma cadeia de prova. Esses procedimentos e formalidades não deverão incluir medidas coercitivas.

(15) A execução de um mandado europeu de obtenção de provas deverá, tanto quanto possível e sem prejuízo das garantias fundamentais previstas no direito interno, ser efectuada em conformidade com as formalidades e os procedimentos expressamente indicados pelo Estado de emissão.

(16) Para garantir a eficácia da cooperação judiciária em matéria penal, deverão limitar-se as possibilidades de recusar o reconhecimento ou a execução do mandado europeu de obtenção de provas, bem como os motivos de adiamento de sua execução. Em especial, a recusa de executar o mandado europeu de obtenção de provas com o fundamento de que o acto que está na sua origem não constitui um infração contemplada no direito interno do Estado de execução (princípio da dupla criminalização) não deverá ser possível para certas categorias de infracções.

(17) Deverá ser possível recursar um mandado europeu de obtenção de provas se o seu reconhecimento ou execução no Estado de execução implicar a violação de uma imunidade ou privilégio nesse Estado. Não existe uma definição comum dos conceitos de imunidade ou privilégio na União Européia, pelo que a definição exacta desses termos cabe ao direito interno e pode incluir a proteção aplicável a profissionais da saúde e do direito mas esses conceitos não deverão ser interpretados de modo a violar a obrigação de abolir determinados motivos de recusa previstos no artigo 7. ${ }^{\circ}$ do Acto do Conselho de 16 de outubro de 2001, que, nos temos do artigo 34. ${ }^{\circ}$ do Tratado da União Europeia, estabelece o Protocolo da Convenção relativa ao auxílio judiciário mútuo em matéria penal entre os Estados-Membros da União Europeia.

(18) Deverá ser possível recursar o reconhecimento ou a execução de um mandado europeu de obtenção de provas na medida em que a sua execução possa prejudicar interesses nacionais essenciais de 
segurança, pôr em perigo a fonte da informação ou implicar o uso de informações classificadas relacionadas com atividades de informação específicas. Contudo, aceita-se que esse motivo seja invocado unicamente quando (e na medida em que) os objetos, documentos ou dados não sejam, por tais razões, utilizados como prova em casos nacionais semelhantes.

(20) É igualmente necessário fixar prazos para garantir uma cooperação rápida, eficaz e coerente no que diz respeito à obtenção de objetos, documentos ou dados para utilização no âmbito de processos penais da União Européia.

(21) Cada Estado-Membro prevê na sua legislação recursos contra os fundamentos materiais subjacentes às decisões com vista à obtenção de provas, nomeadamente no que se refere à necessidade e proporcionalidade da decisão, embora esses recursos possam diferir entre Estados-Membros e ser aplicáveis em diferentes fases do processo." 323

Além da cooperação jurídica entre Estados-membros, qualquer País dos EstadosMembros podem cooperar com Países que não estão não componham o bloco da União, assim como, a própria União Europeia pode cooperar com outros Estados-Nações, sendo certo que este acordo, a princípio, vincularia todos Estados-Membros da União Europeia.

Em dezembro de 2010, deu-se inicio às tratativas de cooperação entre a União Europeia e os Estados-Unidos da América relativo à proteção de dados, este acordo tem por objetivo abranger os dados pessoais transferidos e tratados para efeitos de prevenção, investigação, detecção ou perseguição de infrações penais, incluindo os atos terroristas, no âmbito da cooperação policial e judiciária em matéria penal ${ }^{324}$.

Por fim, não se há de olvidar o princípio da disponibilidade de informação, relativo a peças de informações relevantes para procedimentos criminais, com impressões

\footnotetext{
${ }^{323}$ In jornal oficial da União Europeia de 30.12.2008. L350/72 (PT). Sobre bloqueio de bens, ver decisão quadro 2003-577/JAH, OJ 2003 L196, p. 45.

${ }^{324}$ Ver www.consilium.europa.eu/uedocs/cms_data/doc
} 
digitais etc. Princípio este considerado por muitos com o irmão menor do princípio do reconhecimento mútuo ${ }^{325}$.

Por sua vez a cooperação jurídica internacional no âmbito do Mercosul ${ }^{326}$, dá-se de forma diversa, até mesmo em função da inexistência de um sistema de integração supranacional, como ocorreu na Europa. Na América Latina, cria-se um mercado comum, no qual os países interajam cada vez mais no desenvolvimento de interesses sociais, econômicos, culturais, políticos e de segurança pública.

A estrutura orgânica do MERCOSUL, diversamente da União Europeia, é "de uma organização intergovernamental com objetivos comunitários"327.

Evidentemente que esta interação leva também a problemas da facilitação da criminalidade e necessidade de uma mais célere e eficaz cooperação entre os Estados-Partes do Mercosul, que pode ser alcançada com a criação de mecanismos menos burocráticos.

O protocolo de São Luis (Decreto 3.468/2000 328 ), também denominado Protocolo de Assistência Jurídica Mútua em Assuntos Penais, estabelece as diretrizes básicas da assistência jurídica entre os países membros. Foram ainda assinados dois acordos complementares ao aludido protocolo, com formulários para tramitação dos pedidos cooperacionais, sendo certo que ainda não houve depósito do Brasil, outrossim foram firmados ainda, no âmbito do Mercosul, acordo de assistência jurídica mútua em assuntos penais entre os Estados Parte deste bloco e a Bolívia e o Chile, não tendo havido ainda deposito por parte do Brasil $^{329}$.

Como assentado por Anselmo, a análise do protocolo de San Luis deve ser realizada:

\footnotetext{
${ }^{325}$ SATZGER, Helmut, e ZIMMERMANN, Frank. Dos modelos tradicionais de Cooperação Judicial ao Princípio do Reconhecimento Mútuo: Novos desdobramentos do verdadeiro paradigma da cooperação europeia em matéria penal, p. 435.

${ }^{326}$ Tratado de Assunção, Decreto 335, de 21 de novembro de 2001.

${ }^{327}$ VerVAELE, John A. E. O Mercosul e a integração regional na América do Sul, p. 262.

${ }^{328}$ Juntamente com o Brasil é signatário do protocolo de assistência mútua em matéria penal a Argentina, Uruguai e o Paraguai.

${ }^{329}$ Ver portal.mj.gov.br. Note-se ainda que existe ainda no âmbito do Mercosul, acordo sobre benefício de litigar sem gastos e a assistência jurídica gratuita entre os Estados-Partes (Decreto legislativo 146/04). Com relação ao benefício da justiça gratuita existe acordo entre os Estados-Partes do Mercosul e a Bolívia e Chile, sendo certo, entretanto que ainda não entrou em vigor no Brasil, existindo mensagem ao Congresso Nacional 258/02. Existe ainda acordo de extradição (Decreto legislativo 35/02 - e entre os países do Mercosul e Bolívia e Chile Decreto legislativo 35/02) e de medida cautelares entre os Estados-Partes do Mercosul (Decreto 2.626/98).
} 
“a partir de antecedentes em tratados já existentes, notadamente no plano multilateral. Dentre os instrumentos internacionais que forneceram matizes para o Tratado, podemos apontar a Convenção Europeia Judicial em Matéria Penal de Estrasburgo, datada de 20.04.1959, a Convenção das Nações Unidas sobre Tráfico Ilícito de Entorpecentes e Substâncias Psicotrópicas (Convenção de Viena), convenção Interamericana sobre Assistência Judicial em Matéria Penal da OEA, dentre outros",330.

Conforme previsto em seu artigo $1^{\circ} \mathrm{o}$ "Protocolo tem por finalidade a assistência jurídica mútua em assuntos penais entre as autoridades competentes entre os Estados-Partes", sendo certo que a "assistência será prestada mesmo quando as condutas não constituam delitos no Estado requerido".

No que se refere às provas, a assistência, conforme dispõe o artigo $2^{\circ}$ do Protocolo, compreenderá: i) recepção e produção de provas, tais como testemunhos ou declarações, realização de perícias e exames de pessoas, bens e lugares; ii) notificação de testemunhas ou peritos para o comparecimento voluntário a fim de prestar testemunho no Estado requerente; iii) o traslado de sujeitas a um processo penal para comparecimento como testemunhas no Estado requerente ou com outros propósitos expressamente indicados na solicitação; iv) entrega de documentos e outros elementos de prova; v) medidas acautelatórias sobre bens; e vi) qualquer outra forma de assistência em conformidade com os fins do protocolo.

Note-se que não é facultado às autoridades ou particulares do Estado requerente o exercício de funções reservadas às autoridades no Estado requerido (art. $1^{\circ}, 5$.), salvo quando autorizado pelo Estado requerido, neste caso a presença das autoridades indicadas na solicitação será facultada, durante o cumprimento da diligência de cooperação, sendo permitida a formulação de perguntas, se as leis do Estado requerido autorizarem, sendo certo que os procedimentos adotados na audiência são de acordo com as regras do Estado requerido (art. 17, 3.).

\footnotetext{
${ }^{330}$ ANSELMO, Marcio Adriano. Cooperação Internacional em matéria penal no âmbito do Mercosul Anatomia do Protocolo de San Luis, p. 224/5.
} 
Os pedidos de tramitação da cooperação serão efetuados por meio das Autoridades Centrais de cada Estado-Partes.

No que se refere à iniciativa da cooperação, esta pode ser requerida pelas autoridades judiciais ou Ministério Público, responsável pela apuração dos fatos (artigo $4^{\circ}$, do Protocolo). Observe-se que não se faculta à defesa a possibilidade de obtenção, supressão, exclusão das provas, nem mesmo a possibilidade de se oporem às provas ${ }^{331}$.

Assim, para a defesa, a cooperação fica restrita possibilidade de se utilizar dos canais da diplomacia, com a consularização dos documentos, por ela obtidos diretamente no exterior, ou, ainda, a hipótese de o magistrado requerer a prova, como se do juízo fosse ${ }^{332}$. Entretanto, tais opções não atendem à ampla defesa e ao contraditório, gerando inegável ausência de paridade de armas, além dos custos inerentes à obtenção da cooperação direta pela parte, ignorando-se a população carente.

Note-se, ainda, que, conforme assentado por Bechara, o "protocolo aplica o princípio da especialidade, ao prescrever que, salvo consentimento prévio do Estado requerido, o Estado requerente somente poderá empregar a informação ou a prova obtida na investigação ou no procedimento indicado na solicitação" ${ }^{\text {,333 }}$.

Por fim, cumpre asseverar que, nos termos do artigo $5^{\mathrm{a}}$ do Protocolo, o Estado Parte requerido poderá denegar o pedido de assistência jurídica quando:

“a) a solicitação se refira ao delito tipificado como tal na sua legislação militar mas não na legislação penal ordinária;

b) a solicitação se refira a delito que o Estado requerido considere como político ou como delito comum conexo com delito político ou realizado com finalidade política;

c) a solicitação se referia a delito tributário;

\footnotetext{
${ }^{331}$ Ver, SOUZA, Solange Mendes de. Cooperação jurídica penal no mercosul: Novas possibilidades., p. 200.

${ }^{332}$ ANSELMO, Marcio Adriano. Cooperação internacional em matéria penal no âmbito do Mercosul- anatomia do Protocolo de San Luis, p. 229.

${ }^{333}$ Sobre as limitações no emprego da informação ou prova obtida art. 12, do Protocolo de San Luis ver BECHARA, Fábio Ramazzini. op. cit., p. 181.
} 
d) a pessoa em relação a qual se solicita a medida haja sido absolvida ou haja cumprido condenação no Estado requerido pelo mesmo delito mencionado na solicitação. Contudo, esta disposição não poderá ser invocada para negar assistência em relação a outras pessoas; ou

e) o cumprimento da solicitação seja contrário à segurança, à ordem pública ou a outros interesses essenciais do Estado requerido".

No âmbito da cooperação administrativa, no ano de 2000, O Conselho do Mercado Comum do Mercosul, aprovou a criação do Centro de Coordenação e Capacitação Policial do Mercosul, por meio do acordo 11/00, ratificado pelos Estados-Partes e aderido pelo Chile e Bolívia.

Aludido Centro, objetivando neutralizar as novas e sofisticadas formas da ação delitiva que têm adquirido uma crescente dimensão transnacional, visa a coordenação da capacitação das forças de segurança e policiais dos países que integram o Mercosul. Volta-se para a adoção de processos educativos dinâmicos para a capacitação dos recursos humanos que garantem a segurança pública, baseando-se na difusão de novos conhecimentos científicos e tecnológicos ${ }^{334}$.

Além deste Centro, existem acordos firmados pelas polícias para combate do tráfico de pessoas, crimes praticados pela internet, tráfico de entorpecentes etc. Embora exista a necessidade de uma maior estruturação da cooperação policial, para que no futuro se possa quiçá, criar um polícia comum (Mercopol), tal como ocorre na União Europeia.

Por sua vez, no âmbito do Mercosul, os Ministérios Públicos caminham no processo de integração de suas atividades, considerando a importância de fortalecer a cooperação entre as instituições para tornar mais efetivo o combate à criminalidade ${ }^{335}$.

Cumpre ainda tecer considerações sobre a Convenção Interamericana de Assistência Mútua em Matéria Penal (Decreto $n^{\circ}$ 6.340, de 3 de janeiro de 2008), entre os Estados-Membros da Organizações dos Estados Americanos (OEA).

\footnotetext{
${ }^{334}$ www.mercosur.int/msweb/Normas/normas_web/Decisiones/PT/Dec_016_000_Centro\%20Capacita\%C3\%A7 \%C3\%A3o\%20Policial_Ata\%201_00.PDF

${ }^{335}$ Ver noticias.pgr.mpf.gov.br/noticias-do-site/copy_of_pdfs/declaracao
} 
Conforme dispõe o artigo $2^{\circ}$, alínea $e$, da Carta da OEA, estabelece como propósito essencial dos Estados americanos "procurar a solução dos problemas políticos, jurídicos e econômicos que surgirem entre os Estados membros”.

Visando atender este propósito, os países da OEA adotam de regras comuns no campo da assistência mútua em matéria penal. A assistência jurídica entre os Estados-Partes se dará por meio da autoridade central.

Também nesta Convenção, conforme previsto no artigo $5^{\circ}$, dispensa-se a necessidade de dupla incriminação "Quando o pedido de assistência referir-se às seguintes medidas:a) embargo e seqüestro de bens; b) inspeções e confiscos, incluindo buscas domiciliares, o Estado requerido poderá não prestar a assistência se o fato que der origem ao pedido não for punível de conformidade com sua legislação”.

A assistência mútua em matéria penal prevista nesta Convenção compreenderá, entre outros, os seguintes atos: notificação de decisões judiciais e sentenças; recebimento de prova testemunhal e declarações de pessoas; citação de testemunhas e peritos a fim de prestar depoimento; realização de inspeções ou confiscos; exame de objetos e locais; exibição de documentos judiciais; remessa de documentos, relatórios, informação e elementos de prova; transferência de pessoas detidas, para os efeitos desta Convenção ${ }^{336}$.

O Estado requerido poderá recusar a assistência quando, em sua opinião:

“a) o pedido de assistência for usado com o objetivo de julgar uma pessoa por um delito pelo qual essa pessoa já tiver sido previamente condenada ou absolvida num processo no Estado requerente ou requerido; b) a investigação for iniciada com o objetivo de processar, punir ou discriminar de alguma maneira uma pessoa ou grupo de pessoas, por motivo de sexo, raça, condição social, nacionalidade, religião ou ideologia; c) o pedido se referir a delito político ou relacionado com delito político, ou a delito comum que estiver sendo processado por motivos políticos; d) se tratar de pedido de assistência emanado de um tribunal de exceção ou de um tribunal ad hoc; e) for afetada a ordem pública, soberania, segurança ou interesses públicos fundamentais; e f) o pedido se referir a um delito fiscal. Não obstante,

\footnotetext{
${ }^{336}$ Ver artigo $7^{\circ}$ da Convenção, Decreto n ${ }^{\circ} 6.340$, de 3 de janeiro de 2008.
} 
prestar-se-á a assistência se o delito for cometido por uma declaração intencionalmente falsa feita verbalmente ou por escrito, ou por uma omissão intencional de declaração, com o objetivo de ocultar receitas provenientes de qualquer outro delito previsto nesta Convenção",337.

Note-se, ainda que a lei a ser aplicada no cumprimento da assistência mútua é a do Estado requerido.

Ademais, os pedidos relativos à busca, embargo, sequestro e entrega de qualquer item, compreendidos, entre outros, documentos, antecedentes ou objetos, só serão atendidos, se o pedido contiver informação justificando a medida proposta ${ }^{338}$.

Além destes tratados, existem outros relevantes tratados multilaterais, como a Convenção Interamericana contra a Corrupção (Decreto $\mathrm{n}^{\circ}$ 4.410/02) e a Convenção Interamericana contra o terrorismo (Decreto $\mathrm{n}^{\circ}$ 5.369/05).

No que se refere à Convenção contra a Corrupção ${ }^{339}$, estipula-se que os Estados devem prestar a assistência mais ampla possível, veja o que dispõe o artigo XIV:

“1. Os Estados Partes prestarão a mais ampla assistência reciproca, em conformidade com suas leis e com os tratados aplicáveis, dando curso às solicitações emanadas de suas autoridades que, de acordo com seu direito interno, tenham faculdades para investigar ou processar atos de corrupção definidos nesta Convenção, com vistas à obtenção de provas e à realização de outros atos necessários para

\footnotetext{
${ }^{337}$ Ver artigo $9^{\circ}$, da Convenção, Decreto n ${ }^{\circ} 6.340$, de 3 de janeiro de 2008.

${ }^{338}$ Ver artigo 13, da Convenção, Decreto n 6.340, de 3 de janeiro de 2008.

${ }^{339}$ A convenção define como atos de corrupção, em seu artigo VI: “a) a solicitação ou a aceitação, direta ou indiretamente, por um funcionário público ou pessoa que exerça funções públicas, de qualquer objeto de valor pecuniário ou de outros benefícios como dádivas, favores, promessas ou vantagens para si mesmo ou para outra pessoa ou entidade em troca da realização ou omissão de qualquer ato no exercício de suas funções públicas; $b$. a oferta ou outorga, direta ou indiretamente, a um funcionário público ou pessoa que exerça funções públicas, de qualquer objeto de valor pecuniário ou de outros benefícios como dádivas, favores, promessas ou vantagens a esse funcionário público ou outra pessoa ou entidade em troca da realização ou omissão de qualquer ato no exercício de suas funções públicas; c. a realização, por parte de um funcionário público ou pessoa que exerça funções públicas, de qualquer ato ou omissão no exercício de suas funções, a fim de obter ilicitamente benefícios para si mesmo ou para um terceiro; d. o aproveitamento doloso ou a ocultação de bens provenientes de qualquer dos atos a que se refere este artigo; e e. a participação, como autor, co-autor, instigador, cúmplice, acobertador ou mediante qualquer outro modo na perpetração, na tentativa de perpetração ou na associação ou confabulação para perpetrar qualquer dos atos a que se refere este artigo".
} 
facilitar os processos e as diligências ligadas à investigação ou processo penal por atos de corrupção.

2. Além disso, os Estados Partes prestarão igualmente a mais ampla cooperação técnica reciproca sobre as formas e métodos mais efetivos para prevenir, detectar, investigar e punir atos de corrupção.Com esta finalidade, facilitarão o intercâmbio de experiências por meio de acordos e reuniões entre os órgãos e instituições competentes e dispensarão atenção especial às formas e métodos de participação civil na luta contra a corrupção".

Curioso observar que esta Convenção, não possibilita aos Estados-Partes que invoquem a cláusula do sigilo bancário como empecilho à cooperação. Devendo, neste ponto, existir uma coordenação desta como forma de cooperação, com direitos e garantias assegurados internacionalmente. Note-se, entretanto, que a Convenção se preocupa com o sigilo dos dados transmitidos, proibindo a sua divulgação ou utilização para outros fins sem a devida autorização ${ }^{340}$.

Com relação à Convenção Interamericana contra o terrorismo, assinada em Barbados em 2003, que objetiva prevenir, punir e eliminar o terrorismo. Nesta Convenção, de acordo com o artigo $4^{\circ}$, os Estados-Partes se comprometem a estabelecer regime jurídico e administrativo para prevenir, combater e erradicar o financiamento do terrorismo e lograr uma cooperação internacional eficaz a respeito, a qual deverá incluir:

“a) Um amplo regime interno normativo e de supervisão de bancos, outras instituições financeiras e outras entidades consideradas particularmente suscetíveis de ser utilizadas para financiar atividades terroristas. Este regime destacará os requisitos relativos à identificação

\footnotetext{
340، Artigo XVI. Sigilo bancário. 1. O Estado Parte não poderá negar-se a proporcionar a assistência solicitada pelo Estado Parte requerente alegando sigilo bancário. Este artigo será aplicado pelo Estado Parte requerido em conformidade com seu direito interno, com suas disposições processuais e com os acordos bilaterais ou multilaterais que o vinculem ao Estado Parte requerente. 2. O Estado Parte requerente compromete-se a não usar informações protegidas por sigilo bancário que receba para propósito algum que não o do processo que motivou a solicitação, salvo com autorização do Estado Parte requerido".
} 
de clientes, conservação de registros e comunicação de transações suspeitas ou incomuns.

b) Medidas de detecção e vigilância de movimentos transfronteiriços de dinheiro em efetivo, instrumentos negociáveis ao portador e outros movimentos relevantes de valores. Estas medidas estarão sujeitas a salvaguardas para garantir o devido uso da informação e não deverão impedir o movimento legítimo de capitais.

c) Medidas que assegurem que as autoridades competentes dedicadas ao combate dos delitos estabelecidos nos instrumentos internacionais enumerados no Artigo 2 tenham a capacidade de cooperar e intercambiar informações nos planos nacional e internacional, em conformidade com as condições prescritas no direito interno. Com essa finalidade, cada Estado Parte deverá estabelecer e manter uma unidade de inteligência financeira que seja o centro nacional para coleta, análise e divulgação de informações relevantes sobre lavagem de dinheiro e financiamento do terrorismo. Cada Estado Parte deverá informar o Secretário- Geral da Organização dos Estados Americanos sobre a autoridade designada como sua unidade de inteligência financeira"

No âmbito da cooperação, os Estados-Partes deverão promover o intercâmbio de informações, visando o aperfeiçoamento das medidas de controle fronteiriças e aduaneiras, bem como dos controles de emissão de documentos de viagem e identidade, de forma a evitar falsificações, adulterações ou utilização fraudulenta. Devem, ainda, os Estados-Partes, criar canais de comunicação entre as autoridades competentes, assegurando intercâmbio seguro e rápido de informações ${ }^{341}$.

Assim como na Convenção sobre corrupção, os Estados-Partes devem prestar mutuamente a mais ampla e expedita assistência jurídica possível. Assegurando, inclusive que a inaplicabilidade da exceção por delito político (já que os delitos elencados na Convenção não podem ser considerados com o políticos ou conexos a estes), a proibição de concessão de

\footnotetext{
${ }^{341}$ Ver art. $8^{\mathrm{o}}$, do Decreto $\mathrm{n}^{\mathrm{o}} 5.369 / 05$.
} 
asilo ou de refúgio. A única hipótese prevista para a negativa da cooperação é a que se refere àquelas situações nas quais o Estado requerido tiver fundadas razões para acreditar que se trata de discriminação, por motivos de raça, religião, nacionalidade, origem étnica ou opinião política.

Observe-se, entretanto, que de bom alvitre, a Convenção, em seu artigo 15 acentua, expressamente, que as suas disposições devem ser interpretadas e levadas a cabo com pleno respeito ao Estado de Direito, aos direitos humanos e às liberdades fundamentais.

No campo transnacional, vale destacar a existência dos seguintes tratados: Convenção Contra o Tráfico Ilícito de Entorpecentes e Substâncias Psicotrópicas (Decreto 154/91); Convenção das Nações Unidas contra a Corrupção (Decreto 5.687/06), Convenção das Nações Unidas contra o Crime Organizado Transnacional e seu protocolo adicional (Decreto 5.015/04 e Decreto 5.941/06); Protocolo contra a fabricação e o Tráfico Ilícito de Armas de Fogo, suas Peças, Componentes e Munições, complementando a Convenção das Nações Unidas contra o Crime Organizado Transnacional (Decreto 5.016/04); Convenção internacional para Supressão do Financiamento Terrorista (Decreto 5.640/05) e Convenção sobre o Combate da Corrupção de Funcionários Públicos Estrangeiros em Transações Comerciais Internacionais (Decreto 3.678/00).

\subsection{Considerações sobre os Tratados Bilaterais firmados pelo Brasil e outros Estados-Nações relativos à cooperação jurídica com matéria penal.}

Além do campo regional e transnacional, o Brasil também firmou tratados bilaterais de cooperação jurídica internacional.

Dentre os tratados convém citar: (i) Tratado de Assistência Mútua em Matéria Penal entre o Brasil e Canadá (Decreto 6.747/09); (ii) Tratado entre o Brasil e a China sobre Assistência Mútua em Matéria Penal (Decreto 6.282/07); (iii) Acordo de Cooperação Jurídica Internacional e Assistência Mútua em Matéria Penal entre Brasil e a Colômbia (Decreto 3.895/01); (iv) Acordo entre o Brasil e a República da Coréia sobre Assistência Mútua em Matéria Penal (Decreto 5.721/06); (v) Acordo de Cooperação Jurídica em Matéria Penal entre o Brasil e Cuba (Decreto 6.462/08); (vi) Acordo de Cooperação e Auxilio Jurídico Mútuo em Matéria Penal entre Brasil e Espanha (Decreto 6.681/08); (vii) Acordo de Assistência 
Judiciária em Matéria Penal entre o Brasil e os EUA - MLAT (Decreto 3.810/01); (viii) Acordo de Cooperação Jurídica em Matéria Penal entre o Brasil e a França (Decreto 3.324/99); (ix) Tratado sobre Cooperação Judiciária em Matéria Penal entre o Brasil e a Itália (Decreto 862/93); (x) Acordo de Assistência Jurídica em Matéria Penal entre o Brasil e o Peru (Decreto 3.988/01); (xi) Tratado de Auxílio Mútuo em Matéria Penal, entre o Governo do Brasil e Portugal (Decreto 1.320/94); (xii) Tratado de Cooperação Jurídica em Matéria Penal entre o Brasil e a Suíça (Decreto 6.974/09); (xiii) Tratado entre o Brasil e o Suriname sobre Assistência Jurídica Mútua em Matéria Penal (Decreto 6.832/09); (xiv) Acordo de Assistência Judiciária em Matéria Penal entre o Brasil e a Ucrânia (Decreto 5.984/06) ${ }^{342}$.

Diante da grande quantidade de tratados bilaterais, abordaremos tão somente as linhas gerais dos acordos de cooperação, com seus principais obstáculos, destacando, curiosidades que afetam o direito à produção da prova ou interferem na sua admissibilidade.

Os tratados acima permitem a cooperação para a produção de provas no estado requerido, prevendo a oitiva de testemunhas, encaminhamento de documentos, buscas e apreensões, quebra de sigilos, dentre outros atos, sendo certo que, a lei a ser aplicada será aquela do país requerido, embora, existam tratados que assegurem a possibilidade de que o país requerente possa fazer algumas considerações quanto à forma da cooperação, desde que não desrespeite a legislação do país requerido.

Como regra, os tratados cooperacionais estabelecem que as cooperações devem ser feitas por intermédio da autoridade central, dos países envolvidos.

É preciso ver que países com os Estados Unidos da América, que adotam o sistema adversarial, acabam por inviabilizar a cooperação jurídica internacional para a defesa, impedindo-se assim o exercício do contraditório e a possibilidade de produção de provas naquele país. Um dos maiores problemas que se tem enfrentado é a impossibilidade da oitiva de testemunhas arroladas pela defesa, pelo não cumprimento da cooperação, nestes casos.

Uma alternativa para se tentar garantir a paridade de armas é a possibilidade de o juiz considerar a prova como indispensável, requerendo-a como se do juízo fosse, ou ainda, existe a possibilidade de a defesa obter a prova via procedimento diplomático consular. Evidentemente que questões afetas à validade e valoração da prova, serão afetas pela forma

\footnotetext{
${ }^{342}$ Além destes tratados existem diversos outros, dos quais o Brasil é signatário, relativos às cartas rogatórias, tai como com o Chile, Portugal, EUA, etc. Em vários destes tratados dispensa-se a legalização consular da carta rogatória, como no caso dos EUA, o que facilita a tramitação das cartas rogatórias.
} 
como a cooperação é processada, afinal, uma coisa é a oitiva de testemunhas no exterior, com perguntas e reperguntas das partes e do próprio juízo, outra é a declaração unilateral obtida por uma das partes.

Neste diapasão vale mencionar os ensinamentos de Antenor Madruga:

“Apesar de a cooperação jurídica internacional não precisar, na maior parte das vezes, do concurso de advogados privados estrangeiros, alguns países limitam a ajuda recíproca, nesta área específica, aos pedidos em que a Justiça pública é interessada.

Veja-se o exemplo da cooperação jurídica em matéria penal entre os Estados Unidos da América e o Brasil. De acordo com a interpretação que os Estados Unidos atualmente dão ao tratado que disciplina essa cooperação, a produção de provas no processo penal, quando de interesse da defesa, não pode ser pedida por essa via de cooperação, apenas os pedidos de interesse do Ministério Público ou juiz, desde que não provocados pela defesa.

A interpretação é que esse seria um tratado de cooperação para as funções investigatória e persecutória do Estado. Para a defesa, restaria contratar advogados locais para produzir a própria prova. E se o réu ou investigado não tem recursos, esse seria um problema de assistência jurídica gratuita e não de cooperação jurídica internacional" $" 343$.

Curioso mencionar, ainda, o acordo de cooperação com Portugal que limita o momento processual no qual a cooperação poderá se dar, embora o auxílio abranja: a) a notificação de documentos; b) a obtenção de meios de provas; c) exames de pessoas, lugares ou coisas, revistas, buscas e apreensões de bens; d) a notificação de suspeitos, arguidos ou indicados, testemunhas ou peritos e a audição dos mesmos; e) as informações sobre o direito

\footnotetext{
${ }^{343}$ MADRUGA, Antenor. Cooperação e Assistência Jurídica Internacional, in http://www.conjur.com.br/2011-out19/cooperacao-internacional-cooperacao-assistencia-juridica-internacional.
} 
respectivo e as relativas aos antecedentes penais de suspeitos, arguidos ou indicados e condenados. Vejamos o que dispõe o artigo $1^{\circ}$, item 3.

“o auxílio não abrange os atos processuais posteriores à decisão judicial de recebimento da acusação ou de pronúncia do arguido”.

Evidentemente que restrições como estas, além de constituírem um empecilho ao exercício da defesa, não atendem às necessidades de uma cooperação rápida e eficaz. Assim, os pleitos quando já tiver sido instaurada a ação penal, devem se dar por meio da tradicional carta rogatória.

Interessante assentar, com relação ao tratado de auxílio mútuo com Portugal, que um dos motivos que possibilita a recusa à cooperação é ofensa aos direitos e liberdades fundamentais da pessoa, ou ainda, quando existirem fundadas razões que tornariam desproporcional a concessão do auxílio. Nestes casos, a parte requerida poderá, antes de recusar o acordo, impor condições para o seu cumprimento. Esta é uma preocupação que deveria ser abrangida por todos os acordos cooperacionais.

O tratado de cooperação com a Suíça é exemplar, no que se refere os direitos humanos, devendo a cláusula do artigo $3^{\circ}$ ser padrão em todos os acordos internacionais de cooperação, embora, apenas a sua inclusão no tratado não resolva as problemáticas existentes. Vejamos:

“ARTIGO 3.

1. A cooperação jurídica poderá ser recusada:

f) se existirem razões sérias para acreditar que o procedimento penal contra a pessoa processada não respeita as garantias estipuladas nos instrumentos internacionais de proteção aos direitos humanos, particularmente no Pacto Internacional relativo aos Direitos Civis e Políticos, de 16 de dezembro de 1996".

Com relação à necessidade de dupla incriminação para a cooperação, há diversidade entre os tratados. V.g. No tratado de cooperação jurídica internacional com a 
França, Correia e Portugal, um dos motivos de recusa da cooperação é exatamente o fato de a infração não ser punível em ambos os países, por sua vez os acordos de Cooperação com Canadá, China, Colômbia ${ }^{344}$, Cuba, Espanha, EUA ${ }^{345}$, Itália, Peru, não preveem este requisito.

De fato, existem inúmeros empecilhos para a cooperação bilateral, tais como a segurança nacional, a ordem pública e a soberania nacional, critério da dupla incriminação, o fato da prova ser vedada no país requerido, quando se apurar crime político, quando o crime for militar, quando a investigação for iniciada com objetivo de discriminar pessoas ou grupos em razão de raça, sexo, condição social, nacionalidade, religião, ideologia etc, que afetam a efetividade da cooperação jurídica em matéria penal.

É preciso ver que alguns destes empecilhos são de bom alvitre, afinal, hodiernamente, a busca da verdade atingível, não pode e não deve ser obtida com infringência das garantias assegurados pelos direitos humanos, inerentes ao Justo Processo.

Além destes empecilhos contidos nos dispositivos legais, a ausência de uma lei de cooperação jurídica internacional, a falta de harmonização das legislações e do entendimento que os países possuem sobre a aplicabilidade dos direitos e garantias fundamentais e a diversidade de sistemas processuais (em especial entre adversarial ${ }^{346}$ e acusatório ${ }^{347}$, embora as demais diversidades de sistemas também interfiram na cooperação ${ }^{348}$ ), diminuem a eficácia

\footnotetext{
${ }^{344}$ Embora no tratado com a Colômbia exista a possibilidade de recusa da cooperação quando o pedido referir-se a delito tipificado como tal na legislação militar, mas não na legislação penal ordinária.

${ }^{345}$ Embora no tratado com os EUA exista a possibilidade de recursa da cooperação na hipótese de referir-se a delito previsto na legislação militar, sem contudo, constituir crime comum.

${ }^{346}$ A gestão da prova, constitui uma das principais distinção entre estes sistemas. Conforme assentado por MALAN, Diogo Rudge, Direito ao confronto no processo penal, Rio de Janeiro: Lumen Iuris, 2009, p. 19/20. "O sistema adversarial tende a favorecer órgãos jurisdicionais integrados por jurados. (...). A iniciativa instrutória das partes processuais, por sua vez, é consequência lógica das sobreditas neutralidade e passividade. A idéia central afastar o julgador da gestão probatória na contenda, forçando as partes processuais a investigar e propor os elementos de prova que entendam mais persuasivos. Pressuposto desses atributos do órgão julgador é a sua ignorância acerca dos fatos sob julgamento”. Sobre a diversidade de sistemas na América Latina ver CHOUKR, Fauzi Hassan, O relacionamento entre o Ministério Público e a Polícia Judiciária no processo penal acusatório, in CHOUKR, Fauzi Hassan e AMBOS, Kai (cord.), Processo penal e estado de direito, Campinas: Edicamp, 2002, p. 149/172.

${ }^{347}$ COLOMBER, Juan-Luis Gómez, A investigação criminal Problemas atuais e perspectivas e Unificação Internacional, in CHOUKR, Fauzi Hassan e AMBOS, Kai (cord.), CHOUKR, Fauzi Hassan (trad.), Processo penal e estado de direito, Campinas: Edicamp, 2002, p. 204. "Sua configuração, porém é muito distinta nos países anglo-saxões, em face dos seguidores do sistema francês de ajuizamento criminal, porque na Inglaterra e nos Estados Unidos o princípio acusatório sempre foi entendido em seu sentido mais puro possível, enquanto que na Europa continental coexistiu com o princípio inquisitivo dando lugar a sistemas de ajuizamento misto (o chamado processo acusatório formal)"”.

${ }^{348}$ Sobre a diversidade de sistemas ver FERNANDES, Antonio Scarace, "Prova e sucedâneos da prova no processo penal (Extraído do relatório para a XX Jornadas Ibero americanas de direito processual penal em
} 
da cooperação jurídica internacional e podem levar à inadmissibilidade da prova produzida no exterior.

Outra questão que merece atenção nos tratados de cooperação é a possibilidade da prova obtida ser utilizada em outro processo. Inexiste uma uniformidade no assunto. Alguns tratados são omissos quanto a esta possibilidade, como é o caso da Itália e França, outros colocam como regra o dever de confidencialidade, salvo com autorização da Parte requerida, como é o caso de Portugal ${ }^{349}$ e Canadá ${ }^{350}$, outros ainda estipulam como regra a possibilidade de compartilhamento da prova, exceto nos casos em que exigida autorização do Estado requerido, como no caso dos EUA.

A título de exemplo, veja o que dispõe o tratado com os EUA, no artigo VII, que trata das restrições de uso:

\footnotetext{
Málaga, Espanha 2006)", in Revista Brasileira de Ciências Criminais, São Paulo: RT, nº 66, maio/junho de 2007, p.196. "Dois aspectos fundamentais merecem realce prévio: a diversidade dos sistemas quanto à unidade, duplicidade ou pluralidade de ordens de regência ou de legislações processuais penais e a diversidade de estruturas procedimentais. (...) Nos países que preveem três fases procedimentais, a noção de prova, ou de prova verdadeira como acentuou o Dr. Manuel Ortells Ramos, leva em conta a sua produção concentrada na audiência de julgamento ( $3^{a}$ fase), com imediação e plena contradição das partes. Bem significativa, nesse ponto, afirmação feita pela relatora colombiana, com base no Código de Processo Penal de seu país, de que só se estima como prova a que tenha sido produzida e incorporada em forma pública, oral e concentrada, sujeita a confrontação e a contradição ante o juiz de conhecimento. No Brasil, em que somente nos processos de júri há procedimento com três fases, prevendo-se nos demais apenas duas, uma de investigação policial e outra de instrução judicial, sem concentração dos atos de produção de prova em audiência final de julgamento, ressalta-se na conceituação de prova somente a necessidade de sua produção perante o juiz e com a participação das partes em contraditório".

${ }^{349} \mathrm{O}$ tratado com Portugal prevê a possibilidade de confidencialidade do objeto da cooperação quer pela parte requerida, quer pela parte requerente, veja o que dispõe o artigo 12, do Decreto 1.320/94. "Confidencialidade. 1. A parte requerida, se tal lhe for solicitado manterá a confidencialidade do pedido de auxílio. Se o pedido, não puder ser cumprido sem quebra da confidencialidade, a Parte requerida informará a Parte requerente, a qual decide, então se o pedido deve, mesmo assim ser executado. 2. A parte requerente, se tal lhe for solicitado, mantém a confidencialidade das provas e das informações prestadas pela Parte requerida, salvo na medida em que essas provas e informações sejam necessárias para o processo referido no pedido.. 3. A Parte requerente não deve usar, sem prévio consentimento da Parte requerida, as provas obtidas, nem as informações delas derivadas para fins diversos dos indicados nos pedidos".

${ }^{350}$ ARTIGO 12, do Decreto 6.747, de 22 de janeiro de 2009. "Limitação de Uso das Informações e Confidencialidade. 1. O Estado requerido poderá solicitar, após consultar o Estado requerente, que as informações ou provas fornecidas ou a fonte dessas informações ou provas sejam mantidas em caráter confidencial, ou reveladas ou usadas somente de acordo com os termos e as condições especificadas pelo mesmo. 2.O Estado requerente não deverá revelar ou usar informações ou provas fornecidas para quaisquer outras finalidades que não as definidas na solicitação sem o consentimento prévio da autoridade central do Estado requerido. 3.O Estado requerido deverá, na medida solicitada, manter confidencial uma solicitação, seus teores, documentos de apoio e qualquer ação tomada em relação à solicitação, revelando apenas o estritamente necessário para a sua execução, salvo autorização específica do Estado requerido, de acordo com os termos e as condições que ele possa especificar. 4.Com ressalva do parágrafo 3 deste artigo, caso a solicitação não possa ser executada sem quebrara confidencialidade estipulada na mesma, o Estado requerido deverá informar o Estado requerente dessa situação e este, por sua vez, deverá determinar até que ponto deseja ver executada a sua solicitação”.
} 
"1. A autoridade central do Estado Requerido pode solicitar que o Estado Requerente deixe de usar qualquer informação ou prova obtida por força deste Acordo de investigação, inquérito, ação penal ou procedimentos outros que não aqueles descritos na solicitação, sem o prévio consentimento da Autoridade Central do Estado Requerido. Nesses casos, o Estado Requerente deverá respeitar as condições estabelecidas.

1. A Autoridade Central do Estado Requerido poderá requerer que as informações ou provas produzidas por força do presente Acordo sejam mantidas confidenciais ou usadas apenas sob os termos e condições por ela especificados. Caso o Estado Requerente aceite as informações ou provas sujeitas a essas condições, ele deverá respeitar tais condições.

2. Nenhum dos dispositivos contidos neste Artigo constituirá impedimento ao uso ou ao fornecimento das informações na medida em que haja obrigação constitucional nesse sentido do Estado Requerente, no âmbito de uma ação penal. O Estado Requerente deve notificar previamente o Estado Requerido de qualquer proposta de fornecimento de tais informações.

3. Informações ou prova que tenham sido tornadas públicas no Estado Requerente, nos termos do parágrafo 1 ou 2, podem, daí por diante, ser usadas para qualquer fim".

Em outros tratados, como entre o Brasil e a Suiça ${ }^{351}$, no qual existe a restrição da cooperação quanto às infrações fiscais, veda-se o compartilhamento da fonte, meios e provas obtidas pela via cooperacional:

“ARTIGO 13

\footnotetext{
${ }^{351}$ Embora o tratado preveja como hipótese de recusa da cooperação o fato de se apurar infração fiscal, possibilita-se, conforme artigo 3, 1, c, ao Estado requerido atender a "um pedido se a investigação ou o procedimento visar fraude em matéria fiscal. Se o pedido referir-se somente em parte a infrações fiscais, o Estado Requerido tem a possibilidade de limitar, nesta parte, a utilização das informações e meios de provas fornecidos".
} 


\section{Utilização restrita}

1. as informações, documentos ou objetos pela via da cooperação jurídica não podem, no Estado Requerente, ser utilizados em investigações, nem ser produzidos como meios de prova em qualquer procedimento penal relativo a um delito em relação ao qual a cooperação jurídica não possa ser concedida".

Note-se, ainda que alguns tratados prevejam a possibilidade do encaminhamento espontâneo de meios de prova e informações. Como é o caso do tratado com a Suíça, que dispõe em seu artigo 29 que:

"Por intermédio das Autoridades Centrais, e nos limites de seu direito interno, as autoridades competentes de cada Estado Contratante podem, sem que um pedido tenha sido apresentado neste sentido, trocar informações e meios de prova envolvendo fatos penalmente puníveis, se avaliarem que esse encaminhamento pode permitir ao outro Estado Contratante:

a) apresentar um pedido de cooperação jurídica nos termos do presente Tratado;

b) iniciar procedimento penal;

c) facilitar o desenvolvimento de uma investigação penal em curso.

2. A Autoridade competente que fornecer informações com base neste artigo poderá, conforme seu direito interno, condicionar o uso de tais informações. As condições estabelecidas deverão ser respeitadas.

No nosso entender, melhor seria que fosse adotada como regra a restrição do uso dos meios de prova, das provas ou das informações obtidas pela via da cooperação aos procedimentos para os quais foram solicitados, concedendo-se, entretanto, a hipótese de autorização de compartilhados em outros procedimentos, pelo Estado requerido, de forma fundamentada. Tal assertiva visa garantir os critérios de necessidade e conveniência e 
adequação dos meios de prova e das provas nos procedimentos penais, impedindo-se que, de forma indiscriminada, um dado obtido em um processo, se prolifere em diversos outros, nos quais não fariam muito sentido, bem como de tentar equilibrar a relação entre acusação e defesa na via cooperacional.

Note-se, ainda que o uso indiscriminado das informações pode gerar irreparáveis prejuízos aos investigados ou acusados em processo penal, afinal, se já é difícil o questionamento quanto à licitude da prova e sua admissibilidade no processo que a originou, isto se torna inviável nos demais procedimentos, até porque não se tem o cuidado de anexar, quer no processo de origem, quer nos demais cópia de toda a tramitação da cooperação, incluindo o procedimento levado a cabo no exterior, seja pela forma do auxilio direto, da carta rogatória, ou mesmo da cooperação direta (sem intermediação da autoridade central).

Ademais, não raro, não se faculta ao investigado ou acusado a possibilidade de exercer a ampla defesa, quando da produção da prova no exterior, de modo a que possa aferir acerca da sua licitude de acordo com as regras do país requerido. A apreciação da defesa, antes do envio da cooperação ao país requente, ainda que de forma diferida, nos casos nos quais o conhecimento prévio do investigado da produção daquela prova inviabilize a sua produção, é fundamental. Evidentemente que o juiz brasileiro jamais poderá averiguar a licitude da prova produzida no país requerido, até porque não pode modificar a decisão daquele Estado-Parte, inclusive, frente ao princípio da confiança, que norteia os tratados cooperacionais.

Destarte, a única possibilidade de a defesa questionar a licitude ou ilicitude da prova é no país requerido. Assim, seria de bom alvitre que os tratados cooperacionais propiciassem assistência jurídica gratuita aos investigados ou acusados, ou ainda, que possibilitassem a advogados particulares alienígenas, com auxilio dos locais, atuar de forma a verificar a licitude do ato e propiciar a sua validade e admissibilidade. Não se está aqui falando da mera possibilidade do exercício de defesa, mas da necessidade da existência desta nos trâmites cooperacionais.

Além disso, é preciso ter cautela na possibilidade de utilização das informações ou provas obtidas pela via da cooperação, quando estas tenham sido tornadas públicas, no Estado Requerente. Primeiramente, deve-se auferir se a publicidade da prova ou da informação se deu de forma lícita, caso contrário, não deverá ser utilizada. 
No que se refere aos requisitos do pedido de auxilio e quanto à forma de cumprimento dos pedidos também não há uma padronização nos tratados cooperacionais. Enquanto alguns tratados preveem normas genéricas, outros são exaustivamente específicos.

\subsection{Reflexos da prova produzida por meio da cooperação jurídica internacional (ordem pública, violação de direitos e garantias individuais, sigilo bancário e fiscal, DNA e sangue).}

Questão controversa acerca do tema abordado ao longo do presente trabalho diz respeito à compatibilização dos acordos de cooperação em relação à ordem pública das nações. Este é um ponto delicado que gera desdobramentos na cooperação jurídica internacional em matéria penal.

Como é cediço, o conceito de ordem pública é abrangente e mutável, variando de acordo com os valores de determinada sociedade, em dada época, modificando-se, inclusive, diante da crescente evolução da globalização e necessidade dos Estados de cooperarem.

Nesse sentido, cabe observar que a ordem pública é o conjunto de valores morais, éticos, sociais, econômicos e culturais de uma nação, em uma determinada época ${ }^{352}$.

E, sendo assim, a nosso ver, o conceito diz respeito à busca, em última análise, da paz social interna de uma sociedade. Por via de consequência, a ordem pública tem por lastro a obediência a princípios jurídicos insculpidos, em regra, nas constituições das nações.

Consequência natural disso é que a matéria de ordem pública, invariavelmente, desagua nos mares da soberania (sobre a qual nos manifestamos anteriormente), mas que, de todo modo, impõe a necessidade de uma maior reflexão acerca dos acordos de cooperação à luz da ordem pública ${ }^{353}$.

\footnotetext{
${ }^{352}$ Segundo BECHARA, Fábio Ramazzini. Cooperação Jurídica Internacional em Matéria Penal, p. 136“A ordem pública é definida como um conjunto de valoração de caráter político, social, econômico ou moral, próprias de uma comunidade determinada, que definem sua fisionomia em um dado momento histórico também determinado. $\mathrm{Ou}$, ainda, como conjunto de valores imperativos que se encontram permeados no ordenamento jurídico e que devem preponderar no exercício da jurisdição”.

${ }^{353}$ id, p. 138 "No âmbito do Direito Internacional, a cláusula de ordem pública sempre representou a autodefesa do ordenamento jurídico soberano e a sua função de tutelar os princípios que lhe conferiram a individualidade num dado momento histórico, e cuja eventual abdicação implicava a sua não existência. Sua função
} 
Logo, como já assentado, em seu artigo $1^{\circ}$, a Constituição Federal estabelece como fundamentos do Estado Democrático de Direito: "I - a soberania; II - a cidadania; III a dignidade da pessoa humana; IV - os valores sociais do trabalho e da livre iniciativa; $\mathrm{V}$ - o pluralismo político”.

Se, como dissemos, a ideia de ordem pública está norteada por princípios que dizem respeito a valores de uma sociedade, acolhidos em sua ordem interna como elemento da paz social, esses mesmos princípios foram erigidos à condição de fundamentos constitucionais (repita-se: cidadania, dignidade da pessoa humana, os valores sociais e da livre iniciativa e pluralismo político - incisos II a V, do art. $\left.1^{\circ} \mathrm{da} C F\right)$.

Portanto, no mesmo plano de fundamento constitucional em relação àqueles supramencionados, encontra-se a soberania, que, por sua vez, pode ser conceituada, sucintamente, como a afirmação, perante a comunidade internacional, dos próprios fundamentos e princípios de seu povo sobre seu território.

Se, da análise do artigo $1^{\circ}$ da Carta Magna, pode-se verificar que a soberania encontra-se topologicamente inserida dentro de outros fundamentos de ordem pública, parece natural estabelecer que a soberania, por si, também é um elemento de ordem pública.

Porém, como já se afirmou anteriormente, o próprio constituinte parece ter procurado - pelo menos sugerir - um viés de preponderância, porquanto, em seu artigo $4^{\circ}$, a Constituição Federal reforça que o Brasil, em suas relações internacionais rege-se, dentre outros, pelos princípios da independência nacional, prevalência dos direitos humanos, da autodeterminação dos povos, da igualdade entre estados, da defesa da paz, solução pacífica dos conflitos e da cooperação entre os povos para o progresso da humanidade.

Cabe aqui fazer a ressalva bem elaborada por Celso D. de Albuquerque Mello. Enquanto o artigo $1^{\mathrm{o}}$ da CF menciona o vocábulo "fundamento" e o art. $4^{\circ}$ se refere a “princípios”, não há, conceitualmente, uma distinção entre os dois termos ${ }^{354}$.

determinava o conteúdo normativo dos princípios fundamentais invocados na proteção contra a agressão externa".

${ }^{354}$ ALBUQUERQUE MELLO, Celso D. de. Direito Constitucional Internacional, p. 124, A palavra fundamento no Direito tem um sentido técnico que é a questão de se pesquisar de onde a norma tira a sua obrigatoriedade. Aplicada aqui no D. Constitucional parece não ter um sentido preciso. Assinala Gonçalves Ferreira Filho: 'Estes fundamentos a que se refere a Constituição são princípios básicos que se pretende levem sempre em conta o governo'. Em outras palavras, 'princípios' e 'fundamentos' têm o mesmo sentido”. 
De todo modo, não obstante a redundância cometida pelo constituinte é fato que temos em nossa Carta Constitucional uma clara ênfase acerca da opção de que se trata de ordem pública, seja quando mencionado que a "soberania" é "fundamento" constitucional $\left(\operatorname{art.~} 1^{\circ}\right)$, seja quando "independência nacional” é um "princípio" estabelecido na Constituição Federal, seja também com a necessidade de cooperação entre os povos.

Porém, já tecemos considerações a respeito da soberania, relativamente à confrontação de tal conceito à luz dos tratados internacionais, oportunidade em que, como procuramos ponderar, a celebração de tratados de cooperação, a rigor, estende o próprio conceito de soberania; vale dizer, a soberania também diz respeito à inserção do país na comunidade internacional, no exercício da sua autodeterminação.

O que importa, no presente tópico, é a matéria acerca da implementação dos acordos de cooperação, frente às matérias de ordem pública, especialmente com relação ao alcance de direitos fundamentais que, para muitos, constitui um empecilho à ampla cooperação.

Parece natural dizer que, como sustentado anteriormente, sendo a ordem pública o conjunto de princípios balizadores de uma sociedade em determinada época, os acordos de cooperação estão indissociavelmente relacionados à obediência da ordem pública interna.

Por outro lado, parece ser paradoxal a ideia de se conceber um acordo de cooperação internacional, especialmente em matéria de prova que, prevendo a aplicação da lei do estado requerido, como regra, e, portanto, a validade daquele sistema jurídico, direta ou indiretamente, expressa ou implicitamente, subverta um princípio de ordem pública.

Porque, insista-se, o conceito de defesa da ordem pública transcende à própria ideia de soberania. Enquanto esta diz respeito à afirmação de um estado nacional, a ordem pública representa o espírito de um povo. Espírito este que, atualmente, deseja cooperar e manter, ao mesmo tempo, suas opções locais e diversidades culturais.

Não se há de negar que hodiernamente existe um constitucionalismo mais aberto, embora estejamos longe da formação de um Estado Constitucional Cooperativo ${ }^{355}$, voltado,

\footnotetext{
${ }^{355}$ HÄBERLE, Peter. Estado constitucional cooperativo, p. 14: “Constitucionalmente, Estado Constitucional cooperativo deveria ser traduzido para o conceito e linguagem jurídicos, como a seguir: 1. através do reconhecimento geral sobre 'abertura ao mundo', 'solidariedade', cooperação internacional e coresponsabilidade: (...); 2. através de formas especiais e graduais de cooperação, (...); 3. através de declarações gerais e universais de direitos humanos (...); 4. através de determinações especiais de direitos fundamentais e
} 
por exemplo, às opções internacionais de preservação da paz e à integração dos direitos humanos no sistema interno.

Talvez o exemplo que mais se aproxime dessa condição, embora ainda muito distante dela, tenha ocorrido quando da criação da Carta de Direitos Fundamentais da União Europeia, em razão da qual surgiram calorosos debates a respeito ${ }^{356}$. Decerto, há de se haver, desde o momento da celebração do acordo internacional até a necessidade de sua interpretação em sede judicial, o indispensável sopesamento das normas (internacional e constitucional), para que prevaleça, em última análise, a ordem pública, afinal, todos os tratados de cooperação jurídica internacional preveem como exceção à cooperação a ofensa à soberania e à ordem pública.

Especificamente no caso brasileiro e, principalmente, no que concerne ao direito penal e processual penal, a implementação dos acordos de cooperação em relação aos preceitos de ordem pública está relacionada ao disciplinamento tangente dos direitos individuais, tais como, por exemplo, o direito à intimidade, vida privada, dentre outros.

Exemplificativamente, pode-se conceber que um acordo internacional de cooperação admita a troca de informações pessoais de um suspeito, quando da investigação da prática de eventual delito. Não se pode aceitar, todavia, que o mesmo acordo não possibilite ao acusado, quando da ação penal decorrente da investigação, saber detalhes das informações que ensejaram a acusação, sob pena de se ferir direito individual do sujeito, que é questão de ordem pública.

direitos humanos com 'efeito externo' (...); através - da gradual - inclusão do direito internacional (...); 6. em geral, através da tematização de 'tarefa comunitárias' (de um lado, os Direitos Humanos e, de outro, ajuda ao desenvolvimento, proteção do meio ambiente, garantia de matéria-prima, combate ao terrorismo, segurança da paz mundial). (...) Conclui o autor, às fls. 71: “O Estado constitucional cooperativo se coloca no lugar do Estado constitucional nacional. Ele é a resposta jurídico-constitucional à mudança do Direito Internacional de direito de coexistência para o direito de cooperação na comunidade (não na sociedade) de Estados, cada vez mais imbricada e constituída, e desenvolve com ela e nela o 'direito comum de cooperação'. A sociedade aberta dos intérpretes da Constituição torna-se internacional. (...) A ciência do Estado constitucional livre e democrático tem sua própria tarefa: Ela somente pode subsistir se perceber, de forma conceitual-dogmática, reponsabilidade regional e global para além do Estado - esta é sua missão ético-constitucional".

${ }^{356}$ ANDRADE, J.C. VIEIRA DE. Carta de Direitos Fundamentais da União Europeia, p. 87. "Se os direitos tiverem um conteúdo determinável por interpretação jurídica, como acontece com a generalidade dos direitos, liberdades e garantias, incluindo as liberdades sociais, em especial com os direitos pessoais e políticos, concebese mais facilmente uma fiscalização da constitucionalidade do direito comunitário, isto é, a possibilidade de o juiz nacional desaplicar normas de direito comunitário por contrariarem preceitos constitucionais. Se os direitos implicarem uma concretização jurídico-política por parte do legislador nacional ou comunitário, como acontece em grande medida com os direitos sociais a prestações, então já não será mais rara a hipótese de desaplicação de direito comunitário" (J.C. VIEIRA DE ANDRADE, A Carta Europeia dos Direitos Fundamentais e as Constituições Nacionais, "in” Carta de Direitos Fundamentais da União Europeia, Coimbra Editora, Coimbra, 2001, p. 87. 
Pode-se, por outro lado, admitir, por força de acordo de cooperação internacional, que determinada atitude seja inserida no direito penal como crime (por exemplo, digamos, a organização criminosa - definida pela Convenção de Palermo ${ }^{357}$ ), porém, obviamente, o mesmo acordo de cooperação não poderá violar os princípios insculpidos nos artigos XXXIX e XL da Constituição Federal ${ }^{358}$, porquanto se tratam de direitos fundamentais e, portanto, relacionam-se com a ordem pública.

Ainda tomando como paradigma a Carta de Direitos Fundamentais da União Europeia, tal instituto jurídico tornou positivado o "princípio da melhor tutela", princípio esse que, ao que nos parece, tende a se tornar universal ${ }^{359}$.

Conclui-se, pois, que a "melhor tutela" é princípio de ordem pública e transcende até a visão tradicional do conceito de soberania. Deste modo, nenhum acordo de cooperação internacional deve aviltar ou mesmo relativizar esse princípio.

Por via de consequência, nenhum acordo de cooperação - por mais que se alardeie acerca de seus aspectos políticos, com relação ao combate ao crime organizado internacional e aos meios de prevenção - pode se contrapor aos direitos fundamentais insculpidos no art. $5^{\circ}$ da Constituição Federal e aos direitos garantidos universalmente nos tratados de direitos humanos.

A única exceção, dentro do princípio da melhor tutela, seria se o acordo de cooperação ampliasse as garantias individuais. Se, como se disse anteriormente e cabe aqui insistir, a adesão a um acordo de cooperação pode ser entendida como uma afirmação da soberania de uma nação, a flexibilização - para não dizer supressão pura e simples das

\footnotetext{
${ }^{357}$ Convenção das Nações Unidas Contra o Crime Organizado Transnacional, realizada em 15/12/2000, aprovada pelo congresso e promulgada pelo Decreto 5.015/04. Observe-se que mesmo antes da existência de lei 12894/2012, que definiu o conceito de organização criminosa em sistema jurídico interno, existia um corrente entendendo que poderia ser utilizada a conceituação da Convenção de Palermo, sem necessidade de lei própria. Embora não seja este o nosso entendimento.

${ }^{358}$ XXXIX: "não há crime sem lei anterior que o defina, nem pena sem prévia cominação legal"; XL: "a lei penal não retroagirá, salvo para beneficiar o réu".

${ }^{359}$ CANOTILHO, José Joaquim Gomes. Direito Constitucional e Teoria da Constituição, p. 526. "O art. $52^{\circ} / 3$ da Carta de Direitos Fundamentais da União Europeia (reproduzido no art. II-53 no 'Projecto de Constituição para a Europa' estabelece um importante e inovador princípio em sede de direitos fundamentais - o princípio da melhor tutela. Este princípio reafirma um princípio básico da interpretação em sede direitos (sic) fundamentais: nenhuma disposição da carta deve ser interpretada no sentido de reduzir o nível de protecção dos direitos fundamentais assegurado pela Convenção Europeia dos Direitos do Homem e pelas Constituições dos EstadosMembros (cfr. Art. $53^{\circ}$ ). No entanto, se a Carta de Direitos Fundamentais garantir uma protecção mais extensa ou mais ampla (ou seja, melhor tutela) ela terá preferência de aplicação relativamente às normas correspondentes da Convenção Europeia e das Constituições dos Estados-Membros".
} 
garantias individuais do cidadão - não se justifica, sob nenhum argumento, porquanto além de se tratar da questão da ordem pública nacional, tais valores estão universalmente consagrados pelos tratados internacionais de direitos humanos, que constituem o marco normativo da cooperação internacional.

Pois bem, diante do raciocínio ora sustentado, temos como simplesmente inadmissíveis a aceitação de meios de prova ou meios de obtenção de provas obtidos pela via cooperacional, quando possam vilipendiar o núcleo essencial dos direitos individuais. Destarte, as interpretações do país, convergindo com as das Cortes Internacionais de Direitos Humanos $^{360}$, quanto à extensão dos direitos fundamentais e universalmente consagrados, devem ser resguardadas.

Como visto, não se advoga aqui, pela prevalência da interpretação nacional, dissociada de uma análise de proteção internacional dos direitos humanos, até porque, nosso país se submeteu à jurisdição da Corte Interamericana de Justiça, como mencionado acima, e é signatário de diversos tratados internacionais garantistas.

Nesse sentir, evidentemente que o princípio da melhor tutela ou da norma mais favorável não resolve, por si só, a questão, afinal, assim como os investigados, as vítimas também são protegidas pelos direitos humanos, devendo-se, portanto, dirimir as questões de direitos da mesma magnitude, por meio da aplicação do princípio da proporcionalidade.

Entretanto, em se tratando de processo penal e da garantia de direitos fundamentais, há que se resguardar, em certa medida, as opções locais quanto à abrangência dos direitos fundamentais, como, por exemplo, o resguardo à intimidade e vida privada, até mesmo pelo respeito às diversidades culturais.

O que, evidentemente, não significa uma apologia a não cooperação, mas o desejo de uma cooperação internacional em matéria penal que, ao mesmo tempo em que respeite o ordenamento jurídico do país requerido, salvaguarde o ordenamento jurídico nacional, de forma a não desestabilizar a própria administração da justiça por meio de decisões antagônicas.

\footnotetext{
${ }^{360}$ Corte Interamericana de Direitos Humanos e Corte Europeia de Direitos Humanos.
} 
É que, por mais que a análise do direito processual penal comparado influa, cada vez mais, no direito interno brasileiro, existem limites para tais ingerências, inclusive, no que ser refere à admissibilidade e nulidade das provas produzidas em outros sistemas legais.

Nesse diapasão, embora estejamos diante de análise diversa, vale trazer à colação o quanto assentado por Gemaque, quando da apreciação da influência do processo penal internacional no processo penal brasileiro:

“(...) há limites jurídicos, os quais se referem às peculiaridades internas da ordem jurídica propriamente dita, ou seja, de como o país enfrenta tecnicamente, sob o ponto de vista do direito, as variadas questões que se apresentam sob o ponto de vista do processo penal. (...)

Não há dúvidas de que muitas vezes as influências podem vir de organismos internacionais ou até de países com tradição na common law, enquanto o direito nacional é da tradição do direito continental ou civil law. O próprio Estatuto de Roma é resultado de uma verdadeira simbiose desses dois sistemas de direito. Assim, alguns mecanismos previstos no plano internacional poderão encontrar resistência no plano interno, tendo em vista as características deste." 361

Nesse sentido, evidentemente que não se admitirá a validade de um meio de prova ou de obtenção de prova proibida no país, tão somente, porque no Estado requerido, este meio é permitido, ou ainda que viole garantias constitucionais, porque sob a ótica do outro Estado não há violação a estes direitos.

Conforme Greco Filho, o direito "não pode ser entendido senão em função da realização de valores, no centro dos quais se encontra o valor da pessoa humana. Aliás, toda ordem jurídica não teria sentido se não tivesse por fim ou conteúdo a realização desses valores",362. $^{\text {, }}$

\footnotetext{
${ }^{361}$ GEMAKE, Silvio Cesar Arouck. A necessária influência do processo penal internacional no processo penal brasileiro, p. 63.

${ }^{362}$ GRECO FILHO, Vicente, Tutela Constitucional das Liberdades, p. 8.
} 
De início, excluem-se a utilização das chamadas provas obtidas por meios ilícitos (art. $5^{\circ}$, LVI, da CF). Já tivemos a oportunidade, anteriormente, de abordar acerca das provas ilícitas ou ilegais. Já mencionamos, da mesma forma, acerca do princípio da proporcionalidade no que tange às hipóteses de sua admissibilidade, para posterior valoração.

Tais reflexões levaram em consideração os aspectos da natureza probatória enquanto elemento do processo. O que se pretende no presente tópico, é elevar a discussão, levando-se em conta os direitos individuais assegurados internacionalmente e a necessária higidez do processo penal brasileiro, resguardando-se a tipicidade processual penal.

A problemática agrava-se com questões afetas não à ilicitude do momento da prova em si, já que em determinado sistema (país requerido) ela pode ter sido produzida licitamente (de acordo com as regras daquele país, regras estas as quais o Brasil se submete ao assinar tratados que prevejam que na cooperação vigora a regra do país requerido), mas com sua integração no sistema legal brasileiro.

Efetivamente, a questã coloca-se sob a dicotomia entre o princípio da confiança, no qual os Estados acreditam e admitem como válido, sistemas legais diversos do seu, e as opções nacionais quanto à amplitude e incidência dos valores fundamentais na cooperação jurídica internacional.

Para dirimir eventuais conflitos que surjam com relação à possível violação a direitos individuais, decorrentes, em especial, das diferentes opções locais quanto aos procedimentos para a violação destes direitos, ou mesmo quanto ao alcance destes, é indispensável, verificar qual é o "âmbito de proteção" dos direitos individuais.

Conforme assentado por Gilmar Mendes:

“Em relação ao âmbito de proteção de um determinado direito individual, faz-se necessário que se identifique não só o objeto da proteção ( $O$ que é efetivamente protegido?), mas também contra que tipo de agressão ou restrição se outorga essa proteção. Não integraria o âmbito de proteção qualquer assertiva relacionada com a possibilidade de limitação ou restrição a determinado direito.

Isso significa que o âmbito de proteção não se confunde com a proteção efetiva e definitiva, garantindo-se a possibilidade de que 
determinada situação tenha a sua legitimidade aferida em face de dado parâmetro constitucional"363.

Nesse sentido, para se auferir se é possível a aceitação da prova produzida em outro ordenamento jurídico - que interpreta de forma e extensão diversa os mesmo direitos fundamentais assegurados, inclusive, pelos direitos humanos - é preciso verifica, em nosso ordenamento, se esta aceitação acabará por aniquilar a própria garantia individual, ou seja, se irá atingir o núcleo essencial do direito assegurado.

O exemplo que salta à evidência, diz respeito ao direito à personalidade, a intimidade e à privacidade ${ }^{364}$. Direitos estes afetados pela produção de provas no exterior, em especial pela divergência quanto ao alcance dos mesmos. Evidentemente que não se devem aceitar ingerências arbitrárias ou abusivas na vida privada, na família, no domicílio ou na correspondência de pessoas.

É, sobretudo, diante da concepção de que o investigado ou acusado é reconhecido como sujeito do processo - e não mais como mero espectador - que se pode compreender a abrangência e relevância dos direitos à intimidade ${ }^{365}$, a privacidade e à personalidade ${ }^{366}$ do ser humano exercem no processo penal ${ }^{367}$.

\footnotetext{
${ }^{363}$ MENDES, Gilmar Ferreira. Limitações dos direitos fundamentais, p. 220. Não se pretende discutir neste trabalho questões afetas às diversas teorias sobre o âmbito de proteção dos direitos fundamentais. Conforme afirmado pelo autor na p. 219: "O âmbito de proteção de um direito fundamental abrange diferentes pressupostos fáticos e jurídicos contemplados na norma jurídica (v.g., reunir-se sob determinadas condições) e a consequência comum, a proteção fundamental. Descrevem-se os bens ou objetos protegidos ou garantidos pelos direitos fundamentais. Nos direitos fundamentais de proteção ou de defesa cuida-se de normas sobre elementos básicos de determinadas ações ou condutas explicitadas de forma lapidar: propriedade, liberdade de imprensa, inviolabilidade do domicílio, dentre outros".

${ }^{364}$ SILVA, José Afonso da. Curso de Direito Constitucional Positivo, p. 189. "O direito à intimidade é quase sempre considerado como sinônimo do direito à privacidade. Esta é uma terminologia do direito angloamericano (right of privacy) (...). Nos termos da Constituição, contudo é plausivel a distinção que estamos fazendo, já que o inciso $X$ do art. $5^{\circ}$ separa a intimidade de outras manifestações da privacidade: vida privada, honra e imagem das pessoas".

${ }^{365}$ LAFER, Celso. A reconstrução dos direitos humanos: um diálogo com o pensamento de Hanna Arendt, $\mathrm{p}$. 239. "O direito à intimidade é hoje parte integrante dos direitos da personalidade. Tutela o direito do indivíduo de esta só e a possibilidade e a possibilidade que deve ter toda a pessoa de excluir do conhecimento de terceiros aquilo que só a ele se refere, e que diz respeito ao seu modo de ser no âmbito da vida privada".

${ }^{366} \mathrm{Cf}$. MIRANDA, Jorge. Manual de Direito Constitucional, p. 58: "Os direitos de personalidade são posiçães jurídicas fundamentais do homem que ele tem pelo simples fato de nascer e viver; são aspectos imediatos da exigência de integração do homem, são condições essenciais ao seu ser".

${ }^{367}$ COSTA JR., Paulo José da. O direito de estar só: Tutela penal da intimidade, p. 49. Ver, artigo $5^{\circ}$, inciso X, da $\mathrm{CF} / 88$.
} 
De fato, há remansoso posicionamento da Doutrina:

"Em outras palavras, a privacidade de uma pessoa, assim como ocorre com a liberdade de locomoção, não pode ser afastada pela ideia de supremacia do direito público sobre o privado. A interferência do direito público na areado direito privado só é admissível quando encontrar licença no ordenamento constitucional. Por isso, a admissão da quebra da intimidade pela via da interceptação telefônica, v.g., é condicionada à existência de 'ordem judicial' e para fim de investigação criminal ou instrução processual penal (artigo $5^{\circ}$, inciso XII da Constituição Federal) "368.

Não importa se, em cooperação internacional, tenha se tolerado, com mais ou menos frequência, a possibilidade, em algum ordenamento jurídico, por exemplo, de escuta telefônica sem autorização judicial, ou sem motivação ou ainda sem o resguardo do sigilo das informações obtidas $^{369}$ - por ser isso possível no ordenamento jurídico interno de alguma nação participante de tal acordo.

Parafraseando Zilli, ainda que sobre a prova paire uma aura de credibilidade, para auferir a sua admissibilidade, deve o julgador averiguar o grau de comprometimento da integridade do processo, ou seja, se a sua admissão afetará o processo causando-lhe graves prejuízos $^{370}$.

\footnotetext{
${ }^{368}$ MIRANDA, Jorge; MARQUES DA SILVA, Marco Antonio (coord). Tratado Luso-brasileiro da Dignidade Humana, p. 49.

${ }^{369}$ Acerca do entendimento da Corte Interamericana quanto aos direitos dos investigados em casos de interceptação telefônica, vale mencionar o caso paradigmático caso Escher, envolvendo o Brasil no qual Assentou a Corte que embora as conversações telefônicas não se encontrem expressamente previstas no artigo 11 da Convenção, trata-se de uma forma de comunicação incluída no âmbito de proteção da vida privada (art. 11, da Convenção Americana de Direitos Humanos), que não pode, portanto, sofrer ingerências arbitrárias do Estado ou de terceiros. $\mathrm{O}$ respeito à vida privada, constitui, no processo penal, limite lícito à publicidade dos atos da interceptação telefônica, não sendo admissível que o Estado viole ou permita que seja violado sigilo legal imposto no processo, que vise resguardar a privacidade dos investigados e acusados. Este caso é acessível no sítio da internet da Corte Interamericana de Direitos Humanos.
}

${ }^{370}$ ZILLI, Marcos Alexandre Coelho. A prova ilícita e o tribunal penal internacional: regaras de admissibilidade, Tese apresentada ao curso de Pós-Graduação da Faculdade de Direito da Universidade de São Paulo, área de concentração em direito processual, sob a orientação do Prof. Dr. Antonio Magalhaes Gomes Filho, em 2006, p. 242. 
$\mathrm{O}$ que deve prevalecer em matéria de admissibilidade da prova acusatória, em nosso sistema legal, é a salvaguarda do núcleo do direito fundamental assegurado ${ }^{371}$, ressaltando-se, evidentemente, que a intepretação interna deve ser balizada pelas decisões das Cortes Internacionais de Direitos Humanos ${ }^{372}$.

A Corte Interamericana de Direitos Humanos já teve oportunidade de assentar que "o exercício de cada direito tem que ser feito com respeito e salvaguarda dos demais direitos fundamentais. Nesse processo cabe o papel fundamental do Estado buscando estabelecer as responsabilidades e sanções necessárias à obtenção de tal propósito"373.

Na Europa, apesar das severas críticas, os Estados gozam de uma certa margem de apreciação, na qual podem adotar as opções locais. Nesse sentir, "a recolha de provas releva, antes de mais nada, as regras de direito interno do Estado membro, competindo às jurisdições nacionais apreciar os elementos de prova recolhidos"374.

Antevendo a intensificação da polêmica, Ada Pellegrini Grinover pondera que:

“O certo é que a prevalência das regras voltadas à tutela dos direitos e liberdades do indivíduo, no confronto com as que configuram a obrigação de prestar cooperação internacional, pode ser afirmada recorrendo a diversos critérios hermenêuticos. Mas a conclusão é uma só: a predominância do núcleo fundamental dos direitos e garantias sobre as demais normas.

De acordo com essa postura, vale lembrar o precedente da Corte Europeia dos Direitos do Homem no caso Soering, cidadão alemão

\footnotetext{
${ }^{371}$ OLIVEIRA MILER, Marcello Paranhos. op. cit., p. 80.

${ }^{372}$ Segundo BARRETO, Ireneu Cabral. A convenção européia dos direitos do homem. Anotada., p. 193. " 1. Segundo o $n^{o} 2$ deste artigo, a ingerência da autoridade pública na vida privada, familiar, no domicílio e na correspondência da pessoa deve estar «prevista na lei», «ser necessária numa sociedade democrática» a um dos objetivos ali enumerados: segurança nacional, segurança pública, bem-estar econômico do país, defesa da ordem e prevenção de infracções penais, proteção da saúde ou da moral, proteção dos direitos e das liberdades de terceiros. (...) A lei deve fixar o conteúdo da restrição; porém, quando a lei confere um poder de apreciação será impossível chegar a uma precisão absoluta na sua redação, pois acarretaria, como provável resultado de um tal esforço, uma rigidez excessiva do texto. (...).

${ }^{373}$ Tradução livre de trecho do julgado do corte, no caso TRISTAN DONOSO v. PANAMÁ. O caso pode acessado no sítio da internet da Corte Interamericana de Justiça.

${ }^{374}$ BARRETO, Ireneu Cabral. A convenção europeia dos direitos do homem. Anotada, p. 174. “A tarefa dos órgãos da Convenção consiste em examinar se o processo, no seu conjunto, incluindo o modo de apresentação das provas, reveste um carácter equitativo, sancionando toda a recusa abusiva ou arbitrária”.
} 
cuja extradição os Estados Unidos da América requereram ao Reino Unido. A Corte, a quem recorreu o extraditando, ordenou ao Reino Unido a observância de suas obrigações decorrentes da Convenção européia dos direitos do homem, com a recusa da extradição de Soering aos Estados Unidos da América, onde riscaria (sic) de ser condenado à morte e, consequentemente, de ficar submetido a aguardar no 'corredor da morte', em isolamento, por tempo indeterminado, o que equivaleria a um tratamento desumano banido pelo art. $3^{\circ}$ da Convenção. Foi esta circunstância, e não o risco de pena de morte, que impediu a extradição",375.

Da mesma forma, tem-se a questão acerca da quebra de sigilo fiscal e bancário do cidadão, sem que seja por meio de autorização judicial, questão esta que está em voga, cada vez mais, diante da intensificação do combate ao crime contra o sistema financeiro e a lavagem de dinheiro.

É de se lamentar, deveras, as insistentes tentativas de se colocar em segundo plano direito tão elementar do cidadão, em nome de uma suposta prova de interesse público para apuração destes eventuais crimes.

Vale dizer, qualquer acordo de cooperação que vislumbre meio alternativo - ou seja, sem autorização judicial - para implementar a quebra de sigilo fiscal e bancário de um suspeito, certamente não poderá ser recepcionado pelo Direito Pátrio, porquanto - a exemplo do quanto citamos com relação à escuta telefônica sem autorização judicial - tratar-se-ia de violação de direito fundamental do cidadão, ou seja, ensejaria a subversão da ordem pública interna.

O posicionamento, que ora defendemos, converge ao escólio de Scarance Fernandes:

"Ademais, entre duas interpretações possíveis - a que defende a reserva de jurisdição para a produção de prova mediante quebra de

\footnotetext{
${ }^{375}$ GRIVONER, Ada Pellegrini Grinover. Processo Penal Transnacional: Linhas Evolutivas e Garantias Processuais, in Revista Brasileira de Ciências Criminais, ano 3., vol. 9, p. 49.
} 
sigilo financeiro e que a afasta - deve-se acolher a que privilegia o direito individual. Isso porque as interpretações sobre restrições a direitos individuais devem ser estritas, não ampliativas. Por outro lado, a Constituição Federal, no artigo $4^{\circ}$, II, determina a prevalência, em suas relações internacionais, dos direitos individuais, não tendo sentido que, no plano interno, não seja seguida a mesma regra de prioridade em caso de dúvida na exegese das normas constitucionais.

Por fim, para regular aplicação do princípio constitucional da proporcionalidade na quebra de sigilo financeiro, exige-se a observância de seus requisitos e, entre eles, o da judicialidade, ou seja, o da necessidade de que uma medida restritiva a direito individual seja imposta por um juiz.

Extraída da reserva da jurisdição da Constituição, conclui-se que não pode a lei ordinária atribuir ao Ministério Público ou à autoridade policial poderes para, diretamente, quebrar o sigilo financeiro a fim de se produzir prova em inquérito policial ou processo criminal”376.

Em razão disso, é de causar preocupação, por meio do Decreto Legislativo 211/2013, que o Brasil tenha firmado acordo bilateral com os Estados Unidos da América, aderindo ao "FACTA" (Foreign Account Tax Compliance Act), para a troca, entre os dois países, de informações tributárias envolvendo contribuintes brasileiros e americanos entre a Receita Federal do Brasil e o Internal Revenue Service (IRS), ainda que pretenda tal acordo o combate à sonegação e evasão de divisas.

No nosso entendimento, contudo, a troca de informações dessa natureza viola direito fundamental consagrado em nossa Constituição Federal, porque prescinde da necessidade de determinação judicial para sua implementação e, em última análise, viola princípio de ordem pública.

Atualmente, vivenciamos no Brasil o crescente uso do auxílio direito entre membros do Ministério Público, na persecução penal. Não obstante o auxílio direto constitua

\footnotetext{
${ }^{376}$ FERNANDES, Antonio Scarance. O Sigilo Financeiro e a Prova Criminal, p. 471.
} 
uma forma mais célere de cooperação, por vezes, acaba por violar os direitos fundamentais, afetando, inclusive a ordem pública.

Outra questão atinente à quebra de sigilo bancário e fiscal, refere-se à possibilidade de o Ministério Público, via contato direto com membros de Ministérios Públicos de outros países, solicitar que o órgão alienígena tome as providências para determinar a quebra do sigilo no exterior sem, contudo, passar, no Brasil, pelo crivo judicial, que perquirirá acerca da necessidade, pertinência e relevância da prova no caso concreto.

Estas situações têm ocorrido com certa frequência nas cooperações com os Estados Unidos da América. Membros do Ministério Público, ou mesmo autoridades policiais, requerem, diretamente aos órgãos congêneres daqueles países, por exemplo, a obtenção de informações financeiras presentes nas instituições bancárias daquele país.

Acatando o pedido cooperacional, o District Attorney dos EUA, requisita as informações às instituições financeiras, sendo certo que naquele país isto pode ser obtido com autorização do grad jury e encaminha as informações às autoridades brasileiras, que passam a utiliza-las na persecução penal. Exemplo rumoroso no país foi o denominado caso Banestado, que deflagrou a operação Farol da Colina, leva a cabo pela Polícia Federal.

Se não bastasse a irregularidade em si de autoridades brasileiras terem ignorado a necessidade de reserva de jurisdição em nosso país e a violação ao sigilo legal, a situação agrava-se com a possibilidade de se obter, via cooperacional, informações inclusive de dados existentes em instituições financeiras no Brasil, sem aval do judiciário. Explicamos melhor.

Nos EUA, quando autoridades requisitam informações bancárias naquele país, ainda que unilateralmente, as instituições financeiras têm o dever de fornecer os dados, inclusive das informações constantes de filiais do banco no exterior ${ }^{377}$. Assim, a autoridade

${ }^{377}$ Ver USA Patriot Act. A Seção 5318 k, in www.ficen.gov/news_room/ea/files/hartsfieldassessement.pdf. “The Secretary of the Treasury or the U.S. Attorney General 'may issue a summons or subpoena to any foreign bank that maintains a correspondent account in the United States and request records related to such correspondent account, including records maintained outside of the United States relating to the deposit of funds into the foreign bank [emphasis added].' 31 U.S.C. $§ 5318(\mathrm{k})(3)(\mathrm{A})(\mathrm{i})$. The summons or subpoena 'may be served on the foreign bank in the United States . if the foreign bank has a representative in the United States [emphasis added].' 31 U.S.C. $\$ 5318(\mathrm{k})(3)(A)(\mathrm{ii})$. Similar language is contained in 31 CFR 103.185.”

Ver também United States Attorney's Manual pr. 9-13-525 Subpoenas, in www.justice.gov/eousa/foia_reading_room/usam/title9/13mcrm.htm\#9-13.525. "Since the use of unilateral compulsory measures can adversely affect United States law enforcement relationship with a foreign country, all Federal prosecutors must obtain written approval through the Office of International Affairs (OIA) before issuing any subpoenas to persons or entities in the United States for records located abroad. See the Criminal

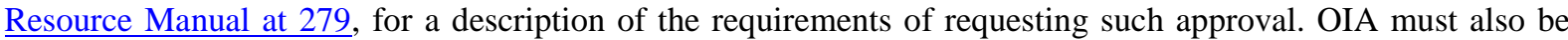


policial ou o Ministério Público, por via transversa, acabaria por obter dados de sigilo bancário existentes no Brasil, sem a obediência da reserva de jurisdição. O que, no nosso sentir é inadmissível.

Analisando a questão, Moro $^{378}$, esclarece que:

“As autoridades norte-americanas, na esteira do entendimento de que os tratados não constituem um meio exclusivo para colheita de prova no exterior, estão autorizadas, pela lei federal e pela jurisprudência, a servir-se de medidas de cunho unilateral para obtenção de documentos bancários no exterior. (...)

'Falando genericamente, há dois métodos não baseados em tratados para obter documentos bancários no exterior. Primeiro, uma subpena como a autorizada no precedente Bank of Nova Scotia pode ser usada para obter documentos em filiais bancárias no exterior, de bancos que, possuem filiais nos Estados Unidos. Por exemplo, se o sujeito tem uma conta no HSBC em Hong Kong, a filial nos Estados Unidos pode receber a ordem. No entanto, antes de pleitear esse tipo de subpoena, um Procurador deve primeiro obter uma aprovação do Escritório de Assuntos Internacionais (Office of International Affairs - OIA) da Divisão Criminal do Departamento de Justiça, segundo as diretivas contidas no Manual de Recursos Criminal."

Prossegue, ainda citando Hampton:

consulted prior to initiating enforcement proceedings relating to such subpoenas. OIA's approval must be obtained prior to serving a subpoena ad testificandum on an officer of, or attorney for, a foreign bank or corporation who is temporarily in or passing through the United States when the testimony sought relates to the officer's or attorney's duties in connection with the operation of the bank or corporation. [cited in USAM 913.520; Criminal Resource Manual 285]".

${ }^{378}$ MORO, Sergio Fernando. Cooperação jurídica internacional em casos criminais: considerações gerais, p. 54. Citando Hampton, Alan. Sources of information in a financial investigation. In: US Department of Justice: Executive Office for United States Attorneys. United States Attorneys'Bulletin. Setembro/2007, vol. 55, n5, p. 51. 
“"Um segundo método para obter documentos bancários no exterior envolve o uso da 31 USC par 5318(k), uma provisão adicionada pela USA Patriotic Act. A seção 5318 (k) autoriza agentes da lei a obter documentos bancários de um banco estrangeiro que possua conta bancária correspondente nos Estados Unidos. Quase todo banco no mundo tem relação com um banco nos Estados Unidos e, portanto, a maioria dos documentos bancários estão teoricamente dentro do alcance". 379

No nosso sentir, em que pese às opiniões em contrário ${ }^{380}$, esta prova não pode ser admitida no ordenamento jurídico brasileiro. Entendemos que, não obstante deva prevalecer a regra do país requerido, quando da produção da prova no exterior, nenhum órgão interno, seja polícia ou ministério público, pode requerer a cooperação internacional, por que via for, sem respeitar a necessidade da apreciação do poder judiciário sobre estas questões ${ }^{381}$, em casos onde existe reserva de jurisdição. Neste caso, o vício do ato estaria no próprio momento da solicitação da cooperação, que teria violado direitos e garantias constitucionalmente assegurados.

Entretanto, a prova relativa a sigilo bancário, fiscal, interceptação telefônica, violação de comunicação telemática, de domicílio, etc. podem advir não por meio de solicitação de autoridades brasileiras, mas pelo envio unilateral de documentos contendo estes dados, ou mesmo acostados às cópias de processos que tramitam, ou tramitaram, no exterior, que ingressarão em nosso ordenamento como prova documental.

\footnotetext{
${ }^{379}$ Op cit, p. 54

${ }^{380}$ Ver LIMA, Luciano Flores e ARAS, Vladimir. Cooperação internacional direta pela polícia ou ministério público, p. 152/3. Para estes autores inexiste necessidade em pedido cooperação relativos a sigilos de dados bancários, fiscais, telefônicos, etc., de prévia autorização do judiciário brasileiro, posto que as leis do Estado Requerido é que disciplinarão a matéria.

${ }^{381}$ MORO, Sergio Fernando. Cooperação jurídica internacional em casos criminais: considerações gerais, p. 31. "Em outras palavras, no caso do sigilo bancário, o encaminhamento da solicitação dependeria de prévia autorização de autoridade judiciária do País Requerente e do atendimento dos requisitos necessários para a decretação de uma quebra de sigilo bancário como se a prova fosse produzida em um processo no próprio País Requerente. Dessa forma, no caso do sigilo bancário, as autoridades do País requerente, que desejam a prova, primeiramente requereriam ao juiz do País Requerente autorização para remessa da solicitação e, uma vez obtida, encaminhariam a solicitação ao País Requerido. Tal exigência tem a vantagem de evita que o princípio locus regit actum resulte em enfraquecimento da proteção dos direitos do acusado ou do investigado no País Requerente".
} 
Neste caso, inexistiria, em si, uma ilegalidade no pedido cooperacional. Entretanto, no nosso entender, ainda assim as informações relativas aos investigados ou acusados, não poderiam ser utilizadas para incriminá-los.

Afinal, abalar-se-ia o núcleo fundamental desde direitos, conforme interpretação constitucional da extensão dos mesmos no país, além de gerar indesejável insegurança jurídica. Neste sentido, se não se admite a violação de sigilo, de comunicação telefônica, dentre outras, sem decisão judicial fundamentada, como poderia ser admissível a aceitação como meios de prova ou de obtenção de prova validos, se violam os mesmos direitos. A única hipótese de admissibilidade de tais meios de prova é, conforme já se assentou anteriormente, se beneficiar à defesa.

Vale neste ensejo, lembra o princípio da máxima efetividade dos direitos fundamentais, que no escólio de Manuel Jorge e Silva Neto:

“a respeito dos direitos e garantias individuais, o princípio da máxima efetividade não guarda apenas uma correspondência lógica; não porta, tão-somente, uma conexidade de sentido com a sistemática constitucional. (...)

Sendo assim, qualquer postura do aplicador do direito que não tome por ponto de partida a concretização de garantia fundamental representa, sem dúvida, não apenas um erro crasso para desnudar o conteúdo do preceito constitucional; é um atentado mesmo contra a própria razão ontológica do ente estatal, ente que - diga-se de passagem., 382

Além da impossibilidade de acordo de cooperação internacional estabelecer restrições ao núcleo dos direitos fundamentais de intimidade, do sigilo fiscal, bancário, das comunicações telefônicas etc., há que se considerar que outro fundamento de ordem pública também se sobreleva.

\footnotetext{
${ }^{382}$ JORGE, Manoel e NETO, Silva. O princípio da Máxima efetividade e a interpretação Constitucional, p. 37.
} 
Voltamos, neste ponto, a aludir ao princípio - anteriormente explanado - de que ninguém é obrigado a fazer prova contra si.

Não obstante o inciso LXIII, do art. $5^{\circ}$, da CF assinale o direito do preso de "permanecer calado" e o Pacto de San José da Costa Rica, em seu art. $8^{\circ}, 2, g$, consagre o direito da pessoa acusada de delito não ser obrigada a "depor contra si mesma, nem declararse culpada”, temos um princípio maior, que extrapola o mero aspecto semântico. Temos um princípio inerente ao direito fundamento à ampla defesa e à própria dignidade humana.

Já a doutrina clássica, representada pelo saudoso José Frederico Marques, atentava que:

"De um modo geral, são inadmissíveis os meios de prova, que a lei proíba e aqueles que são incompatíveis com o sistema processual em vigor. Tais são: a) os meios probatórios de invocação ao sobrenatural; b) os meios probatórios que sejam incompatíveis com os princípios do respeito ao direito de defesa e à dignidade da pessoa humana"383.

Salta à evidência, mais uma vez, que os acordos de cooperação internacional não podem estabelecer previsões que adotem consequências negativas ao acusado, quando este se recusar a fazer prova contra si.

Nesse sentir, as autoridades brasileiras, mesmo sabendo que em outros sistemas legais é admissível efetuar exames invasivos sem anuência da parte, como exame de sangue, não poderão requisitar por meio de cooperação estas evidências. Já são inadmissíveis no ordenamento nacional e se pretende utilizá-las em processo neste país.

Por outro lado, no caso de ser encaminhado ao país cópias de processos com de exames não autorizados pelo acusado, tais como de DNA, sangue, confissões mediante coação etc., estas provas não serão admissíveis no país, em respeito ao princípio da dignidade da pessoa humana e até mesmo por questão de segurança jurídica.

Afinal, é inconcebível que se admita a introdução de provas no processo penal brasileiro, cujo meio de obtenção é vedado no país.

\footnotetext{
${ }^{383}$ MARQUES, José Frederico. Elementos de Direito Processual Penal, 268.
} 
A questão posta não se refere à questão da licitude em si no momento da produção da prova, posto que foi obtida de acordo com a legislação do país requerido, mas diz com a sua admissibilidade no sistema jurídico brasileiro. Se por ventura estas provas ingressarem no ordenamento jurídico, deverão ser desentranhadas.

Por fim, necessárias são algumas considerações sobre a prova emprestada, questão que certamente se sobreleva em relação aos tratados internacionais.

Dentre os expedientes judiciais que melhor incorporam o propósito de tornar práticos os princípios processuais da celeridade e economia processuais, encontra-se a prova emprestada, que nada mais é do que a possibilidade de se utilizar, nos autos de um processo judicial, de prova produzida em outro feito ${ }^{384}$.

Contudo, existem alguns requisitos que necessariamente precisam ser superados para que a prova emprestada seja considerada válida no segundo processo.

Em primeiro lugar, a prova emprestada deve ter sido considerada válida no processo de origem. Portanto, por exemplo, uma confissão eivada de vício no primeiro processo não poderá ser utilizada no segundo. Neste ponto, pode existir problemática quanto à admissibilidade da prova, afinal, se a prova produzida no exterior for considerada válida naquele país, mas ferir de morte a dignidade da pessoa, não poderá ser admitida no ordenamento jurídico nacional.

Além disso, é imperioso que a prova emprestada tenha sido submetida ao contraditório entre as partes, tanto no processo de origem, como no segundo. Neste segundo requisito, a problemática torna-se relevante nos processos decorrentes de cooperação internacional.

De início, diga-se que os acordos de cooperação, em regra, dispensam a necessidade de consularização do documento, que se prestará a servir de prova emprestada, tramitando apenas por meio da Autoridade Central.

\footnotetext{
${ }^{384}$ Nesses casos, conforme WAMBIER, Luiz Rodrigues. op. cit., p. 413 “a prova é transportada do primeiro para o segundo processo sob a forma documental. Ou seja, são apresentadas cópias dos documentos que a formalizaram no processo de origem. Por exemplo, se o empréstimo é de uma prova testemunhal, são trazidas para o segundo processo cópias da petição de requerimento da prova testemunhal, da petição de arrolamento da testemunha, da decisão de deferimento da prova, do termo de audiência em que a testemunha foi ouvida, etc.".
} 
Porém, mais relevante dizer, é que a prova emprestada diz respeito a mero procedimento - e não a princípios probatórios - de modo que a necessidade de que, realmente, tenha o acusado participado da prova no processo de origem não se consubstancia em mero exercício formal, mas na própria essência do direito de prova.

Há que se dizer, por via de consequência, que as distâncias, facilitações de ordem tecnológica e troca de informações internacionais entre aqueles que fazem parte dos processos, nada disso justifica a subversão do instituto da prova emprestada.

\subsection{Proposição: da quebra da linearidade rígida pró-defesa para a produção de provas no processo penal}

Nos últimos anos, o processo civil passou por diversas transformações, objetivando tornar mais célere e, sobretudo, efetiva, a tutela jurisdicional. É bem verdade que, para tanto - e com maior ou menor grau de sucesso - alguns fundamentos, que até então se mostravam intocáveis, precisaram ser alterados.

Independentemente da discussão acerca da existência ou não de uma dicotomia entre os processos civil e penal, é fundamental iniciar o estudo por meio de alterações efetuadas no diploma processual civil, quanto a "flexibilização" de procedimentos.

É o caso, por exemplo, da antecipação da tutela, acolhida pela Lei no 9.494/1997 e que alterou a redação do art. 273 do Código de Processo Civil.

Embora seja inevitável reconhecer hoje que as pretendidas efetividade e celeridade do processo judicial não tenham correspondido às expectativas da época em que tal instituto foi inserido em nosso ordenamento jurídico, é fato que houve uma quebra de paradigma.

Vale dizer, se o processo civil era disciplinado por uma rígida linearidade ${ }^{385}$ quanto à forma de sua evolução e pela qual somente ao final poderia haver um

\footnotetext{
${ }^{385}$ CINTRA, Antonio Carlos de Araújo; GRINOVER, Ada Pellegrini; DINAMARCO, Cândido Rangel. Teoria Geral do Processo, p. 284 "O processo é a síntese dessa relação jurídica progressiva (relação processual) e da série de fatos que determinam a sua progressão (procedimento). A sua dialética reside no funcionamento conjugado dessas posições jurídicas e desses atos e fatos, pois o que acontece na experiência concreta do processo é que de um fato nasce sempre uma posição jurídica, com fundamento na qual outro ato do processo é praticado, nascendo daí nova posição jurídica, a qual por sua vez enseja novo ato, e assim até ao final do
} 
pronunciamento jurisdicional (por meio da propriamente chamada "cognição exauriente"), a possibilidade da antecipação da tutela permite que, antes mesmo do regular desenvolvimento do feito - inclusive antes da própria citação do réu! - haja esse pronunciamento.

Trata-se, diferentemente das decisões de natureza cautelar, do próprio conhecimento da questão de fundo colocada à apreciação do Poder Judiciário.

Porém, não se pode olvidar: $\mathrm{O}$ art. 273 do Código de Processo Civil estabelece como requisito para a concessão da antecipação da tutela a existência de prova inequívoca e a verossimilhança dos argumentos das partes.

Prova inequívoca e verossimilhança ${ }^{386}$ ! Dois conceitos aparentemente insípidos e subjacentes na cognição exauriente, mas que, uma vez deslocados do final do processo para algum instante anterior do mesmo, já permite ao magistrado atribuir algum juízo de valor em relação ao fato e ao direito a ser a ele aplicado.

Assim sendo, se o próprio comando jurisdicional pode ser pronunciado ao longo do processo, por que essa quebra de linearidade a que nos referimos anteriormente não pode também ser adotada, no que concerne ao momento da produção das provas? Em tal hipótese, não estaríamos falando de antecipação do provimento jurisdicional propriamente dito, mas de uma cautela, destinada a garantir a utilidade da prova - e, portanto, da aferição da verdade em favor da adequada racionalização do processo.

Ainda tomando por base o direito processual civil, tem-se como exemplo a Medida Cautelar de Produção de Provas (disciplinada nos artigos 846 a 851 do Código de Processo Civil), que tem por pressuposto a urgência que justifique essa antecipação (p. ex., grave enfermidade de testemunha que possa falecer antes da oportunidade de prestar depoimento, ou prova pericial que precise ser realizada em imóvel deteriorado e que, se for aguardado o momento processual adequado, ficará mais deteriorado ainda).

procedimento. Cada ato processual, isto é, cada anel da cadeia que é o procedimento, realiza-se no exercício de um poder, o que significa que é a relação jurídica que dá razão de ser ao procedimento; por sua vez, cada poder, faculdade, ônus, dever, só tem sentido enquanto tende a favorecer a produção de fatos que possibilitarão a consecução do objetivo final do processo".

${ }^{386}$ Para o conceito de verossímil ver ABBAGNANO, Nicola. Dicionário de Filosofia, p. 1000. "O que é semelhante a verdade, sem ter a pretensão de ser verdadeiro (no sentido, p. ex., de representar um fato ou um conjunto de fatos)". 
Conquanto o processo civil, a rigor, não esteja necessariamente comprometido de maneira dogmática com a dita "verdade real" ${ }^{387}$ dos fatos, diferentemente do processo penal bastando uma base formal que possibilite, à luz dos elementos probatórios, que seja viabilizada a cognição suficiente para o pronunciamento jurisdicional - esses princípios inerentes à possibilidade de antecipação da prova podem e devem - e, talvez com maior frequência em relação ao processo civil ${ }^{388}$ - fazer parte da realidade do processo penal, inclusive para a defesa.

É bem verdade que o processo penal brasileiro prevê algumas hipóteses de produção antecipada de prova, mas estas previsões não satisfazem aos anseios e às necessidades da defesa diante desta nova realidade mundial, na qual a cooperação jurídica internacional constitui uma realidade.

Os artigos $92^{389}$ e $366^{390}$, do diploma processual penal, tratam de hipóteses de antecipação de provas quando da suspensão do processo, entretanto, estas produções antecipadas de provas, utilizadas, via de regra, pela acusação pública, devem ser vistas com ressalvas $^{391}$, posto que, por vezes acabam por vilipendiar direitos fundamentais dos acusados, que não podem fazer reperguntas, ou mesmo contraditar a prova testemunhal, no momento de sua produção.

\footnotetext{
${ }^{387}$ Sobre a aparente dicotomia entre verdade formal e material ver, Badaró, Gustavo Henrique Righi Ivahy. Ônus da prova no processo penal,p. 20 ss.

${ }^{388}$ CINTRA, Antonio Carlos de Araújo; GRINOVER, Ada Pellegrini; DINAMARCO, Cândido Rangel. op. cit., p. 284 "A teoria da relação processual, que surgiu com vistas ao processo civil (...) tem igual validade para o direito processual penal ou trabalhista. No campo do processo penal, afirma-se até que o seu reconhecimento atende a razões de conveniência política, pois a afirmação de que há uma relação jurídica entre o Estado-juiz, o órgão da acusação e o acusado (ao qual se atribuem poderes e faculdade de natureza processual) significa a negação da antiga ideia de que este é mero objeto do processo, submetido às atividades estatais percesutórias".

389، “Art. 92.Se a decisão sobre a existência da infração depender da solução de controvérsia, que o juiz repute séria e fundada, sobre o estado civil das pessoas, o curso da ação penal ficará suspenso até que no juízo cível seja a controvérsia dirimida por sentença passada em julgado, sem prejuízo, entretanto, da inquirição de testemunhas ou provas de natureza urgente".

390“'Art. 366. Se o acusado, citado por edital, não comparecer, nem constituir advogado, ficarão suspensos os processo e o prazo prescricional, podendo o juiz determinar a produção antecipada de provas consideradas urgentes e, se for o caso, decretar prisão preventiva, nos termos do disposto no art. 312”. Ver Súmula Súmula 455, do STJ - A decisão que determina a produção antecipada de provas com base no art. 366 do CPP deve ser concretamente fundamentada, não a justificando unicamente o mero decurso do tempo".
}

${ }^{391}$ LOPES JR., Aury. Direito Processual Penal e sua Conformidade Constitucional, p. 31. "Quanto à produção antecipada de provas, muita cautela. Colher antecipadamente um prova, sem a presença do réu ou seu defensor (sim, pois a defesa dativa nesse caso é meramente simbólica, sem qualquer eficácia real), é uma flagrante violação da garantia do contraditório e, por contaminação, do direito de defesa, ambos assegurados no art. $5^{\circ}$, $L V$, da Constituição. Daí porque o ideal é que a produção antecipada seja reservada para casos extremos, em que a prova efetivamente é relevante e sofre o risco real de perecimento. Ainda, nesse caso, deve-se tomar todas as cautelas para documentar da forma mais ampla possivel, incluindo gravações de áudio e vídeo". 
Por sua vez, o artigo $225^{392}$, do diploma processual penal trata da possibilidade de tomada antecipada de testemunhos, nas hipóteses destas virem a se ausentar por enfermidade ou velhice, inspirando receio de que ao tempo da instrução já não existam.

Uma nova abordagem acerca da produção antecipada das provas foi inserida no diploma processual penal, com o advento da reforma introduzida pela lei 11.690/2008, possibilitando, conforme disposto no artigo 156, inciso I, do Código de Processo Penal ${ }^{393}$, que o juiz possa, de ofício, “ordenar, mesmo antes de iniciada a ação penal, a produção antecipada de provas consideradas urgentes e relevantes, observando a necessidade, adequação e proporcionalidade da medida",394.

Entretanto, estas hipóteses, mostram-se insuficientes para fazer frente às necessidades da defesa dos investigados e acusados. Primeiro, porque atribuem ao juiz certo grau de discricionariedade para a análise da necessidade ou não da antecipação da prova; além disso, no que tange às hipóteses dos artigos 92 e 366, existe um evidente viés acusatório nas providências probatórias a serem antecipadas; e finalmente, no que concerne ao inciso I, do art. 156, do CPP, seria mais adequado - em defesa dos princípios defendidos ao longo do presente trabalho - que a possibilidade prevista no referido dispositivo legal, pudesse ser requerida pelas partes - e não apenas a critério do juiz.

Com efeito, note-se que mesmo o novel dispositivo processual confere a oportunidade de produção das provas antes do processo, somente ao juiz, e não às partes, em especial à defesa.

Redunda daí a irrefutável conclusão de que o sistema processual penal brasileiro seja por possibilitar à acusação um certo controle prévio na produção das provas, seja pelo

\footnotetext{
392،Artigo 225. Se qualquer testemunha houver de ausentar-se, ou, por enfermidade ou por velhice, inspirar receio de que ao tempo da instrução criminal já não exista, o juiz poderá, de ofício ou a requerimento das partes, tomar-lhe antecipadamente o depoimento".

393،Artigo 156. A prova da alegação incumbirá a quem a fizer, sendo, porém, facultado ao juiz de ofício: I. ordenar, mesmo antes de iniciada a ação penal, a produção antecipada de provas consideradas urgentes $e$ relevantes, observado a necessidade, adequação e proporcionalidade da medida".

${ }^{394}$ SOUZA NUCCI, Guilherme de. Código de processo penal comentado. Estudo integrado com Direito Penal e Execução Penal. Apresentações esquemáticas da matéria, p. 156. "31. Critérios da necessidade, adequação e proporcionalidade: pode-se afirmar que, como regra, provas urgentes e relevantes são necessárias, adequadas e proporcionais à medida tomada antecipadamente pelo magistrado em relação à sua produção. Afinal, necessário é algo indispensável; adequado; algo apropriado a certo aspecto ou estágio da investigação; proporcional significa situação equilibrada, diante da antecipação e gravidade da produção de uma prova antes de iniciada a ação penal. Porém há exceções".
} 
fato de que as possibilidades de antecipação probatória estão sistematizadas dentro de um escopo pró-acusatório - um desvirtuamento do princípio de paridade de armas.

Até porque, quando falamos em paridade de armas no processo penal, temos em mente a exata e incondicional possibilidade de que o acusado tenha a mesma possibilidade de seu acusador de produzir provas (buscando suas fontes e meios), para demonstrar a sua inocência, nas mesmas condições temporais, geográficas, instrumentais e físicas.

Uma abordagem bastante interessante da temática foi-nos brindada por Flávio Luiz Yarshel, ao tratar do contraditório - ou, melhor dizendo, da falta dele - nas provas préproduzidas pelo Ministério Público ao longo do inquérito civil:

“Com efeito, sem que seja, por ora, necessário proceder a um estudo comparativo propriamente dito, não parece despropositado afirmar que o ordenamento brasileiro, para além de outras medidas que possa prever (e que efetivamente prevê) conhece, ao menos em relação ao Ministério Público, um mecanismo que, quando menos, se aproxima das providências de instrução preliminares disponíveis nos sistemas de “common Law”. Sob outro ângulo, mas de forma análoga, a atribuição de tais prerrogativas ao Ministério Público sugere a existência, ao menos em relação a esse órgão, de um 'dever geral de informação' (...); dever que não resulta de regras de direito material e que, nessa medida, pode ser considerado como tipicamente processual.

É certo que o exercício do que se possa qualificar como poderes de investigação do Ministério Público encontra limites que, quando menos, e para argumentar, deveriam guardar coerência com aqueles que vigoram com o órgão julgador, visto que, não sendo possível a este último exercer poder de instrução de forma arbitrária, seria impensável que tal limite não fosse exigido do Ministério Público.”

Adiante, conclui: 
“A questão, naturalmente, liga-se à da necessidade - ou não - da observância do contraditório na investigação e, em relação ao Ministério Público, no âmbito do inquérito civil. A propósito, embora pareça prevalecer a ideia de que a garantia seria dispensável tendo em vista que ali não se decidem controvérsias e de que se trata de 'mero' procedimento tendente a formar a convicção do Ministério Público, há quem reconheça que o inquérito civil vai além de uma simples sequência de atos encadeados e constitui um procedimento formal que estabelece a constituição de direitos e que gera deveres que ultrapassam o âmbito interno da referida instituição; tudo isso a referendar a ideia de que, ali, tem-se mais do que um mero procedimento." 395

Essa mesma linha de raciocínio nos leva, inevitavelmente, a tecer considerações, também, acerca do inquérito policial.

$\mathrm{O}$ que se verifica nesses procedimentos - inquéritos civil e policial - é o levantamento de elementos de provas a embasar demandas judiciais, com a peculiaridade de que, se no processo penal as partes dispõem de uma forma dialética em relação às provas que vão sendo produzidas ao longo do feito, as provas pré-produzidas mostram-se despidas da possibilidade de manifestação contraditória do acusado.

Não se pretende, cumpre salientar, colocar em discussão as atribuições ou prerrogativas da autoridade policial ou do Ministério Público, nem, tampouco, questionar a utilidade dos inquéritos (civil ou policial).

Por outro lado, não sendo um procedimento contraditório, o inquérito possui, na prática, uma natural - embora não desejável - tendência ao aspecto acusatório, o que, por si só, já deixa contaminada a busca pela verdade atingível.

No entanto, não há como defender o conceito de paridade de armas como sendo um princípio de direito fundamental, se não admitirmos a possibilidade de que seja revisto o procedimento quanto a uma maior e mais efetiva, participação do investigado ou acusado na

\footnotetext{
${ }^{395}$ YARSHELL, Flávio Luiz. Antecipação da prova sem o requisito da urgência e direito autônomo à prova, p. 224.
} 
produção de provas no processo penal (na fase pré-processual ou judicialmente), possibilitando uma postura menos passiva em relação à obtenção da verdade atingível na fase da investigação.

Neste diapasão, vale trazer à colação, as lições de Giuliu Ubertis, acerca da impossibilidade das partes serem postas em condições de desigualdade, sendo certo que a ambas dever ser concedida a paridade de armas durante todo o procedimento criminal:

“O contraditório, além disso, postula que sejam reconhecidas às partes antagônicas uma posição de paridade. (...)

Enfim, é importante comentar que os principais momentos sobre os quais podem ser tuteladas a paridade de armas podem ser identificados como aqueles correspondentes desde a aquisição (distinta em seu momento de admissão e assunção) probatória, até a exposição das argumentações voltadas a persuadir o juiz e às deliberações". 396

O ordenamento jurídico, pois, deve garantir ao investigado - se não a participação, de forma dialética, no próprio inquérito policial - pelo menos a utilização de meios próprios para a realização de sua defesa, em sede pré-processual, tal como ocorre em outros sistemas legais 397 .

\footnotetext{
${ }^{396}$ Tradução livre de UBERTIS, Gilio. Il contraddittorio nella formazione della prove penale, in Estudos em homenagem à Professora Ada Pellegrini Grinover, YARSHAL, Flávio Luiz e ZANOIDE, Mauricio de, São Paulo: DPJ editora, 2005, p. 332/3. Complementa o autor: "Il contradditorrio, peraltro, postula che agli antagonisti sia riconosciuta uma posizione dei parità. Se, inverso, la parità tra le parti, di per sé, nen realiza necessariamente il contraddittorio (potrebbe essere negata a tutti i titolari dei reipettivi interessi la possibilità di interloquire davanti al giudice, avendosi allora uma parità senza contraddittorio), é tuttavia impossibile riscontrare la sussitenza effettiva disso qualora i protagoniste delssa controversia si trovano in uma situazione tale per cui la ragioni dell'uno abbiano uma possibilità di escplicazione maggiori rispetto a quelle dell'altro. Inoltre, la garanzia per làccusto di non essere collocato in situazioni di svantaggio tali da comportare il rischio di uma decisione fondata su elementi non sottoposti al principio della parità delle armi tra le parti opera lungo tutto l'arco del procedimento, ivi comprese le eventuali fasi sai incidentali (come quelle relative in matéria de libertà personale) che di impugnazione, tanto di mérito quanto di legittimità".

${ }^{397}$ Código de Processo Penal Português, art. $61^{\circ}, 1$ : "O arguido goza, em especial, em qualquer fase do processo $e$, salvas as excepções da lei, os direitos de: (...) f) Intervir no inquérito e na instrução, oferecendo provas e requerendo as diligências que se lhes afigurarem necessárias(...)". Ou ainda nos paises que adotaram o sistema adversarial, guardadas as devidas proporções e incompatibilidades entre os sistemas. Ver também artigo 111, da Constituição Italiana, que propiciou avanço para a investigação da defesa. Analisando o processo penal na Itália ver FERNANDES, Antonio Scarance. O equilíbrio na investigação criminal, p. 327, observa que "A reforma sofrida pelo sistema processual italiano é um exemplo interessante sobre a necessidade de, em sistema
} 
É verdade que em nosso diploma legal, o investigado pode, nos termos do artigo 14, Código de Processo Penal, requerer qualquer diligência, entretanto esta será realizada ou não, a juízo da autoridade. No entanto, a prática tem demonstrado que este tipo de restrição ofende e inviabiliza o escorreito exercício do direito constitucional de ampla defesa.

Não obstante não se possa falar no exercício do contraditório no inquérito policial $^{398}$, é indiscutível que a Carta Cidadã, assegura, inclusive em procedimento administrativo (como é o caso do inquérito policial ${ }^{399}$ ), o exercício da ampla defesa (art. 5, inciso LV, da CF/88).

Neste diapasão, vale trazer a colação preciosa lição de Marta Saad ao asseverar que:

"Há que se garantir ao acusado, portanto o direito de defesa, no sentido de resistência, oposição de forças, possibilitando a ele o direito

acusatório, permitir-se ao lado da investigação estatal, outra realizada pela defesa. (...) Era preciso assim regular e reestruturar a realização da investigação pela defesa, o que foi feito pelas Leis 479/99 e 397/2000. Essas leis autorizam a defesa a contratar investigador particular para proceder à investigação e preveem a forma como se realizam as entrevistas às testemunhas. Em primeiro lugar, pode haver uma conversa não documentada; depois, se necessário, a entrevista é reduzida a escrito, para então ser introduzida nos autos. Outra inovação das leis citadas é a possibilidade de a parte desenvolver a investigação sem o auxilio de um defensor".

${ }^{398}$ SAAD, Marta. O direito de defesa no inquérito policial, p. 223. “Assim, se não se mostra apropriado falar em contraditório no curso do inquérito policial, seja porque não há acusação formal, seja porque, na opinião de alguns, sequer há procedimento, não se pode afirmar que não se admite o exercício do direito de defesa, porque esta tem lugar 'em todos os crimes e em qualquer tempo e estado da causa', se se trata de oposição ou resistência à imputação informal, pela ocorrência de lesão ou ameaça de lesão. No mais, é de ser reconhecer que já há acusação, em senso largo, entendida como 'afirmação, ou atribuição de ato ou fato a pessoa autora, coatora ou partícipe', em diversos atos do inquérito policial, como na prisão em flagrante delito; na nota de culpa; no boletim de ocorrência de autoria conhecida; no requerimento, requisição e na portaria de instauração do inquérito policial; ou, ainda, no indiciamento realizado pela autoridade policial, bem como nos diversos provimentos e medidas cautelares, determinados e realizados nessa primeira fase da persecução penal". Sobre a ausência de contraditório na investigação ver posicionamento da Corte Europeia de Direitos Humanos, caso Kostoviski c. Países Baixos.

${ }^{399}$ Existem inúmeras definições acerca do que seja o inquérito policial. Grande parte da doutrina entende que o inquérito policial, visa apurar autoria e materialidade de fato que aparenta ser ilícito e típico, possuindo natureza cautelar, constituindo-se, ainda, em procedimento administrativo com finalidade judiciária. Vale trazer a colação as seguintes definições: PІтомво, Sérgio Marques. A polícia judiciária e as regras orientadoras do processo penal, p. 35. "Trata-se, pois de procedimento cautelar; de natureza administrativa; que contém investigação e instrução policial, acerca de fato, supostamente violante da norma penal; todas as circunstâncias que o envolvem, e respectiva autoria. O fim, o destino do inquérito policial são judiciários. Função, pois, colaborativa, mas específica da polícia por isso judiciária". Para TUCCI, Rogério Lauria, Persecução penal, prisão e liberdade, São Paulo: Saraiva, 1978, p. 47. "Por isso se pode afirma-lo (vistas voltadas, também, pra a sua efetuação por órgão da Administração Pública - a polícia judiciária) procedimento administrativo reduzido a escrito, mediante o qual se inicia a perseguição de infrator de lei penal, visando a coleta de elementos informativos da materialidade do fato e da respectiva autoria de modo inquisitivo e, até sigiloso". 
de se contraporá todas as acusações, com a assistência de advogado, com a possibilidade de manter-se silente, e a admissibilidade de produção de provas por ele requeridas, indispensáveis à demonstração de sua inocência ou de sua culpabilidade diminuída" ${ }^{\natural 00}$.

Afinal, a hodierna doutrina, espelhada nas palavras magistrais de Antonio Scarance Fernandes, tem o seguinte entendimento, cada vez mais remansoso no mundo jurídico:

"Embora a investigação pelo suspeito constitua medida tendente a buscar maior equilíbrio entre a repressão penal e a defesa, ainda encontra sérias resistências derivadas da tradição de investigações marcadamente inquisitoriais. Os dados colhidos pela polícia, pelo Ministério Público ou por juiz são aceitos com grande credibilidade, enquanto aqueles obtidos em investigação do suspeito são vistos com muita reserva.

A possibilidade de investigação paralela pelo próprio suspeito, autorizada e regulada por lei, constitui tentativa de equilibrar a atuação dos órgãos de repressão penal e atuação da defesa. Enquanto não for prevista essa investigação, há pelo menos necessidade de se abrir, cada vez mais, espaço para que se tenha atuação da defesa na fase de investigação. Essas, soluções se tornam ainda mais necessárias quando, como será visto nos próximos capítulos, as alternativas procedimentais modernas apoiam-se em elementos obtidos durante a investigação, colhidos pelo Ministério Público fora do juízo e sem a observância do contraditório.” 401

\footnotetext{
${ }^{400} \mathrm{SAAD}$, Marta. $O$ direito de defesa no inquérito policial, p. 223.

${ }^{401}$ FERNANDES, Antonio Scarance. Teoria Geral do Procedimento e O Procedimento no Processo Penal, $\mathrm{p}$. 86.
} 
$\mathrm{O}$ atual projeto de reforma do Código de Processo Penal, à luz dessa tendência, faz evidenciar a justa preocupação nesse sentido, embora a proposta de participação do investigado ainda seja muito tímida ${ }^{402}$.

É o que se infere, pois, dos termos de seu artigo13:

“Art. 13. É facultado ao investigado, por meio de seu advogado, de defensor público ou de outros mandatários com poderes expressos, tomar a iniciativa de identificar fontes de prova em favor de sua defesa, podendo inclusive entrevistar pessoas.

Parágrafo único. As entrevistas realizadas na forma do caput deste artigo deverão ser precedidas de esclarecimentos sobre seus objetivos e do consentimento das pessoas ouvidas".

A possibilidade que ora se põe em debate, obviamente, não é criar mecanismos que dificultem a investigação criminal, nem, tampouco, de estabelecer uma espécie de, digamos, "contra-inquérito" ou "inquérito paralelo" elaborado pelo acusado, em contraposição ao propósito do inquérito.

O que se procura aqui sustentar é que deve ser amplamente facultado ao acusado a, concomitantemente à fase investigatória, promover a obtenção de fontes e meios de prova, de modo a obter os elementos de informação que serão utilizadas em sua defesa, não podendo mais que tal medida esteja circunscrita apenas no âmbito endoprocessual e no momento e nos parâmetros da linearidade do processo penal, ou ainda, que a atuação defensiva na

\footnotetext{
${ }^{402}$ VIEIRA, Renato Stanziola. Traços adversariais no Projeto de Código de Processo Penal. Uma proposta para o estudo da paridade de armas, in kehdievieira.com.br. "Ainda no âmbito da investigação criminal, a previsão da investigação defensiva no processo penal brasileiro (art. 14, anteprojeto, art. 13, substitutivo e redação final do projeto do Senado) tem importância determinante na configuração do modelo sugerido, rumo ao adversarial system, pois estabelece que a defesa também seja protagonista das fontes de prova a serem apresentadas ao Ministério Público. Tal avanço no tratamento do investigado como sujeito ativo na coleta de fontes de prova (mesmo antes de instaurada a relação processual) possibilita que apresente informações a serem sopesadas pelo órgão responsável por desencadear a ação penal, visando convencê-lo de suas razões, tem nítido caráter de, por conta da iniciativa proof finding e proof presentantion, adversarial. A novidade do tema não esconde sua real importância na medida em que pode antecipar a noção de paridade de armas (...) à fase pré-judicial da persecução penal na medida em que visa equilibrar, entre acusador e acusado, os poderes investigativos, notadamente em sistemas que adotam poderes investigatórios próprios ao Ministério Público".
} 
investigação tenha que passar, necessariamente, pelo crivo indiscriminado da Autoridade Policial ou Judicial (salvo nos casos onde exista reserva de jurisdição).

Outrossim, não se pode olvidar que ,além dos atos de investigação, o inquérito possui atos de instrução, que se dividem em definitivos ou irrepetíveis e em transitórios ou repetíveis.

Diante desta nova dinâmica cooperacional, a defesa, mesmo antes de instaurada a ação penal, ainda na fase da investigação (seja em inquérito policial ou mesmo nas Comissões Parlamentares de Inquérito), por vezes precisa obter uma fonte ou elemento de prova que se encontra no exterior ,ou ainda produzir antecipação à prova, cuja realização deve ser efetuada de imediato, sob pena de perecimento e frustração da medida ou ainda, sem o critério de periculum in mora, como forma de evitar indevidas futuras constrições em seu desfavor (obviamente obedecidos os critérios da necessária, da oportuna e da proporcionalidade).

Fazendo nossas as palavras de Marta Saad:

“os atos irreparáveis possuem efeito judiciário absoluto e se transmitem, de forma definitiva, para o bojo de eventual ação penal. (...) Nessa fase do procedimento penal podem-se produzir ou obter meios de prova definitivos ou irreproduzíveis, que servem de base à acusação e à decretação de medidas e provimentos cautelares, restritivos de direitos individuais e podem, ainda, vir a servir de sustentáculo à eventual sentença condenatória. Em virtude da definitividade de determinados atos praticados no curso do inquérito policial, deve, por conseguinte, ser garantido o exercício do direito de defesa na fase preliminar ou prévia a persecução penal”. ${ }^{403}$

Há que se permitir que a defesa, por meio da cooperação, possa requerer cooperação jurídica internacional para obtenção de prova que influam, inclusive, na análise da concessão ou não de medidas cautelares, de forma a viabilizar o exercício da ampla defesa.

\footnotetext{
${ }^{403}$ SAAD, Marta, O direito de defesa no inquérito policial, p. 176.
} 
Não são poucos os casos, nos quais a defesa necessita da via cooperacional mais dinâmica. Podemos citar como exemplo casos nos quais investigados e acusados no Brasil, são considerados no exterior como vítimas pelas autoridades alienígenas, diante da suspeita da formação de uma quadrilha internacional que, por meio de corrupção, “encomendou”, por questões político-econômicas, a investigação contra estas mesmas pessoas, em curso no país ${ }^{404}$.

Ora, diante de situações como esta, não é razoável que a defesa não possua mecanismos de cooperação tão eficazes quanto aqueles da acusação, ou ainda, não possa, em caso de reserva de jurisdição, tão somente porque não há ação penal previamente constituída, requerer judicialmente a produção antecipada de uma prova pela via cooperacional, visando a não perder o objeto da prova, insuscetível de reparação, ou ainda a se preservar de futura acusação.

Evidentemente, que se deve criar na mentalidade dos aplicadores do direito e dos diplomatas, que negociam os tratados internacionais, uma visão mais equânime quanto aos direitos da defesa.

Neste sentir, há que permitir à defesa a possibilidade efetiva de por meio da cooperação internacional, produzir sem indevidas ingerências, tudo o quanto seja útil à demonstração de sua inocência. O que não tem ocorrido.

Enquanto para a Polícia, para o Ministério Público ${ }^{405}$ e para o próprio Poder Judiciário são criados mecanismos e redes de cooperação, existindo relacionamento direto entre estes diversos órgãos ${ }^{406}$, não se garante à defesa às mesmas possibilidades.

\footnotetext{
${ }^{404}$ Para exemplificar a situação, pode-se citar o caso Telecom na Itália, envolvendo escanda-lo político-financeiro da Itália contemporânea, que teve reflexos na denominada operação Chacal (que tramitou perante a $5^{\mathrm{a}}$ Vara Criminal da Justiça Federal de São Paulo) que desencadeou posteriormente a rumorosa operação Satiagraha (com indevida participação da ABIN - que tramita perante a $6^{\mathrm{a}}$ Vara Criminal da Justiça Federal de São Paulo) no Brasil, levadas a cabo pela Polícia Federal. Ver. Ododo, Giuseppe e Pons, Gionvani, O caso telecom. O mais grave escândalo político-financeiro da Itália contemporânea, 2004; ver também PEREIRA, Raimundo Rodrigues, O escanda-lo Daniel Dantas. Duas investigações, Belo Horizonte: Manifesto, 2010.

${ }^{405}$ LIMA, Luciano Flores de, e ARAS, Vladimir. Cooperação Internacional Direta pela Polícia ou Ministério Público, p. 125. "No âmbito da cooperação penal administrativa ou não-jurisdicional, deverá ser considerada a possibilidade do contato direto entre policiais ou membros do Ministério Público visando à colaboração de outras autoridades não-judiciais de outros países, para obtenção, no exterior, de prova s a serem utilizadas em processo penal brasileiro. Embora em alguns países a cooperação penal realizada pelo Ministério Pùblico seja considerada jurisdicional, partimos da premissa constitucional brasileira, que reserva a esta instituição posição distinta no plano da repartição das funções do Estado".

${ }^{406}$ Exemplo destas redes são a Interpol, Europol, Eurojus, Grupo Egmont (relativo às unidades de inteligência financeira), os join investigativve team (grupos de investigação conjunta), como o auxílio judiciário mútuo em
} 
De modo que a defesa tem sua atuação limitada, quer pela ausência de infraestrutura para a sua atuação, quer pela criação de tratados de cooperação voltados para a persecução penal e não propriamente para o exercício do direito de defesa, quer pela exigência de que os requerimentos devem passar pelo crivo de autoridades públicas.

De fato, inspiradoras são as palavras de José Joaquim Gomes Canotilho:

"Em termos teóricos, a existência de um 'direito subjectivo no
procedimento/processo poderia desenvolver-se a partir da tese de
GOERLICH: qualquer direito material postula uma dimensão
procedimental/processual, e, por isso, reconhecer um 'direito
subjectivo do procedimento/processo', como indispensável para
garantir a eficácia do direito material." 407

Não obstante, seja verdade, exista uma preocupação com a garantia da defesa ${ }^{408}$, na prática acaba se limitando à esfera civil.

No dizeres de Antenor Madruga:

matéria penal entre Estados Unidos e Membros da União Europeia, mencionado, inclusive, na pela Convenção de Palermo em seu artigo 19. Ver Machado, Maíra Rocha, Internacionalização do direito penal. A gestão de problemas internacionais, São Paulo: Ed. 34/Edsp, 2004, p. 64/69. Ver também ANSELMO, Marcio Adriano, "Cooperação Internacional em Matéria Penal no âmbito do Mercosul - Anatomia do Protocolo de San Luis, in BALTAZAR JÚNIOR, José Paulo e LIMA, Luciano Flores de (org.), Cooperação Jurídica Internacional em Matéria Penal, Porto Alegre: Verbo Jurídico, 2010, 219/220.

${ }^{407}$ Canotilho, Joaquim José Gomes. Estudos Sobre Direitos Fundamentais, p. 78.

${ }^{408}$ Ver portalmj.gov. "O tema do acesso internacional à justiça envolve diversos aspectos. Os acordos internacionais de cooperação jurídica em matéria civil (incluindo família), comercial e trabalhista, atualmente vigentes, tratam de alguns desses aspectos, trazendo dispositivos que facilitam esse acesso. Pela sua relevância prática, destacamos os seguintes dispositivos que auxiliam no acesso internacional à justiça .a) a solicitação de assistência jurídica gratuita para atuar perante o judiciário estrangeiro; b) a desobrigação, para iniciar ação perante o judiciário estrangeiro; c) a isenção de custas no cumprimento de pedidos de cooperação jurídica internacional para realização de diligências no exterior, necessária no decorrer da ação judiciária no Brasil: Não há necessidade de reembolso das despesas ordinárias, com exceção dos custos excepcionais como perícia, procedimento especial quando solicitado, etc.". Ver: Convênio de Cooperação Judiciária em Matéria Civil, entre o Brasil e a Espanha; Acordo de cooperação em matéria civil entre o Brasil e a França; Tratado relativo à cooperação e ao reconhecimento e execução de sentença em matéria civil entre o Brasil e a Itália; Convenção entre o Brasil e Bélgica sobre assistência judiciária gratuita; Convenção sobre assistência judiciária gratuita entre o Brasil e Reino dos Países Baixos (Holanda); Convenção entre assistência judiciária gratuita entre Brasil e Portugal; Acordo sobre o benefício da Justiça Gratuita e Assistência Jurídica Gratuita entre os Estados Partes do Mercosul, a Bolívia e o Chile; convenção sobre prestação de alimentos no estrangeiro; Convenção sobre aspectos civis do sequestro internacional e crianças; Convenção interamericana sobre obrigação alimentar; Convenção de Haia sobre o acesso internacional à Justiça (aguardando entrado em vigor no país); Convênio de cooperação judiciária em matéria civil, dentre outros". 
"A relação com a assistência jurídica internacional gratuita é um dos temas menos compreendidos no estudo da cooperação jurídica internacional. (...)

Muitas, o desenvolvimento, conclusão e eficácia dos processos de interesse dos usuários dos serviços da Defensoria Pública no Brasil também dependem de providências fora do território nacional, ou seja, também dependem de cooperação jurídica internacional. Apesar de a cooperação jurídica ser pedida por essa via de cooperação internacional não precisar, na maior parte das vezes, do concurso de advogados privados estrangeiros, alguns países limitam a ajuda recíproca, nesta área específica, aos pedidos em que a Justiça pública é interessada." 409

Se, por um lado, é verdade que a cooperação jurídica internacional em matéria penal constitui uma crescente necessidade no mundo atual, diante da imperiosidade de se criar mecanismos que tornem efetiva a persecução penal, também é verdade que a cooperação deve ser vista pelos olhos da defesa, posto que os direitos a ela inerentes são de altíssimo valor social.

\footnotetext{
${ }^{409}$ Ver MADRUGA, Antenor. Cooperação e assistência jurídica internacional, in www.conjur.com.br/2011-out19.
} 


\section{CONSIDERAÇõES FINAIS}

Retomando afirmações feitas anteriormente, apresentamos as considerações finais deste trabalho.

A sociedade passou por um amplo e profundo processo de modificação, decorrente da globalização da economia, da crescente demanda por segurança pública, em especial, do aumento dos crimes que ultrapassam fronteiras e as questões geopolíticas mundiais.

Fruto deste um processo de globalização contemporânea, rápido e intenso, o mundo enfrenta constantes crises financeiras, sob o impacto da revolução das informações e da necessidade de maior interdependência entre os Estados-Nações, que convivem em um ambiente multicultural, almejando a paz.

Acompanhando este processo dinâmico de mudanças, as constantes incertezas tornaram-se presentes, até e principalmente no campo do Direito, na urgência de se estabelecerem parâmetros universais auferíveis por meio dos direitos humanos. A proteção dos direitos humanos torna-se, por consequência, imperiosa, sendo o fator chave para a convivência dos povos na comunidade internacional.

Considerando que os direitos humanos constituem o padrão normativo universal a ser utilizado como forma de traçar as balizas da cooperação jurídica internacional, atualmente existe uma alentadora multiplicidade de tribunais contemporâneos internacionais, como a Corte Europeia de Direitos Humanos e a Corte Interamericana de Direitos Humanos, dentre outras, reveladora de avanços em busca da realização do ideal da justiça internacional.

Desta forma, a globalização e a cooperação internacional (jurídica ou não) devem ser analisadas em consonância com a política (interna e externa), a economia, e as culturas vivenciadas pelos países soberanos ao longo da história.

Ainda que o fenômeno da cooperação jurídica internacional não seja novo, observa-se que este, entretanto, tem se desenvolvido de forma mais acelerada nos últimos anos, em especial diante da nova realidade política e econômica mundial. 
Com avanço vertiginoso das comunicações e da tecnologia, propiciou-se a criação de um mercado quase que universal, surgindo a necessidade de criação de blocos regionais e sub-regionais.

Os mercados unificaram-se em grande medida e isso suscitou a criação de mais regras multilaterais, bilaterais, ou ainda de reciprocidade, o que intensificou e modificou as relações jurídicas entre os povos, em especial diante de divergências sociais, econômicas, culturais e geopolíticas.

Sabemos que o direito, acompanha os entendimentos políticos e decorre deles, enquanto os tratados internacionais são resultado dos esforços dos países de compatibilizarem suas legislações, ainda que isso suscite conflitos de complexas soluções, devido à tradicional noção de soberania.

No cenário da nova realidade mundial, em especial, do aumento da criminalidade global, da violência e da sensação de insegurança, surge, cada vez mais, uma necessidade de cooperação jurídica entre os Estados e de uma normatização da assistência internacional em matéria penal, de forma a compatibilizar os interesses dos diversos Estados soberanos em reprimir a criminalidade, que ultrapassa fronteiras, com a garantia do respeito aos direitos humanos.

Nossa Carta Política erigiu como um dos princípios que regem as relações internacionais do país a cooperação entre os povos para o progresso da humanidade.

Via de regra, a cooperação internacional no país desenvolveu-se pela diplomacia - podendo ocorrer por meio de tratados internacionais bilaterais e multilaterais, ou não , socorrendo-se dos costumes e princípios do direito internacional.

A cooperação jurídica internacional tem sido objeto de negociações internacionais visando o estabelecimento de regras uniformes para a matéria, de modo a garantir maior rapidez e eficácia no cumprimento das medidas provenientes de outros países ou endereçadas ao exterior.

O ascendente desejo de cooperação entre as Nações afeta a geografia e a geometria do direito internacional. Na Europa, cria-se o Mercado Comum Europeu, com a formação de uma comunidade europeia representativa do processo de integração supranacional, ousado e complexo. 
Na América Latina, por sua vez, formaram-se zonas de livre comércio, com a criação do MERCOSUL, do qual o Brasil faz parte, sendo certo que a cooperação jurídica no âmbito do MERCOSUL vem crescendo intensamente nos últimos tempos.

No processo de redemocratização, o Brasil abriu-se para o direito internacional dos direitos humanos. Desde a promulgação da Carta Cidadã, presenciou-se um busca pelo bloco de constitucionalidade destes direitos, sendo que, a partir de 2004, com a promulgação da Emenda Constitucional 45, os tratados de direito internacionais de direitos humanos passaram a ser aprovados por rito especial e ganharam estatura de norma constitucional.

A relação das normas internacionais com o direito interno nunca se deu de forma serena, tendo surgido ao longo do tempo inúmeros problemas quanto à implementação destas normas no direito interno, entretanto, atualmente esta relação está a rumar para novos horizontes, com a primazia dos direitos humanos.

Desde a Constituição de 1988, testemunha-se o processo de internacionalização do Direito Constitucional somado ao de constitucionalização do Direito Internacional.

Os direitos fundamentais universalmente consagrados não devem ser tidos como reversíveis. É no contraponto entre o desejo de segurança, os direitos das vítimas de crimes e os direitos dos investigados que surge a necessidade de uma harmonização das regras de direito existentes nos diversos sistemas jurídicos, tomando por baliza os direitos humanos, universalmente consagrados.

A globalização surge não só como nova forma de produção capitalista, mas também da universalização dos padrões culturais e da necessidade de comum equacionamento de problemas que afetam a todos.

O contexto político vivenciado no período pós- Guerra Fria e em 11 de setembro levando ao enrijecimento das políticas criminais, que priorizam a segurança e a elaboração de legislações que, ao tentarem reprimir a criminalidade como terrorismo, crime contra o sistema financeiro, organizações criminosa etc., acabam por desrespeitar direitos e garantias individuais, adquirindo um senão antigarantista.

A nova realidade mundial, portanto, possui importante reflexos no âmbito do processo penal, especialmente no que se refere ao direito à prova e ao combate à criminalidade. 
Vivenciamos, inegavelmente, o fenômeno da cooperação jurídica internacional, na qual países procuram estabelecer regras e procedimentos, que auxiliem a apuração dos ilícitos de forma mais célere, almejando a eficácia da solução dos litígios e das questões processuais.

É imprescindível que exista uma parametrização da legislação quanto à cooperação jurídica internacional em matéria penal, com a elaboração de regras básicas que norteiem o procedimento das diversas formas de cooperação jurídica existentes, em especial os destinados à produção da prova penal.

É indispensável que, ao serem elaborados tratados cooperacionais, o Estado leve em conta não apenas a persecução do crime, mas também o exercício do direito de defesa, prevendo, nos próprios tratados, a almejada paridade de armas entre acusação e defesa.

No Brasil, apesar da crescente necessidade, a cooperação jurídica em matéria penal ainda se encontra embrionária, tornando-se necessário o estudo da admissibilidade jurídica, no processo penal, de atos instrutórios e cautelares, produzidos mediante cooperação jurídica internacional em matéria, no sentido de sua parametrização.

Há necessidade de se encontrar um equilíbrio entre os avanços e anseios da sociedade no combate à criminalidade e o respeito aos direitos fundamentais, em especial os relacionados à prova.

Não se pode permitir que o anseio pela celeridade processual e questões relativas à efetividade da cooperação internacional tenham como "efeito colateral" a indesejável violação dos direitos consagrados universalmente.

Não se deve subestimar o perigo da relativização dos direitos fundamentais em prol da preservação da paz pública ou como resposta à crescente criminalidade organizada e globalizada, sob pena de fragilizar a própria ordem democrática fundamental.

No combate, à criminalidade torna-se cada vez mais necessária a obtenção de provas no exterior, de forma a propiciar a busca da verdade atingível. A busca da verdade não pode se dar pautada tão somente pelo enfoque da repressão, deve, sobretudo, estar pautada pelo garantismo, visando propiciar às partes e aos operadores do direito o justo processo.

As questões afetas à cooperação jurídica em matéria penal, no que se refere à prova são analisadas sob o prisma da existência do princípio publicístico e do respeito aos 
direitos humanos, realçando-se a necessidade de se conceder paridade de armas para a defesa na cooperação internacional.

A cooperação jurídica internacional dá-se em diversos ramos do direito, sendo objeto do trabalho tão somente a análise da cooperação jurídica internacional ativa em matéria penal (na qual o Brasil é o Estado requerente).

Resumidamente, a cooperação jurídica internacional em matéria penal, pode ser entendida como toda e qualquer forma de colaboração entre Estados-Nações, que tenha reflexos jurídicos no processo penal e nos direitos individuais dos acusados em geral.

As sociedades nacional e internacional são caracterizadas pela heterogeneidade, sendo que a harmonização normativa pressupõe a incorporação de normas internacionais ao direito interno, alicerçada nos direitos humanos e fundamentais, visando-se a efetividade da cooperação.

O ordenamento jurídico brasileiro não possui de forma estrutura e sistêmica, lei que complemente a cooperação jurídica com o exterior, diversamente do que ocorre em outros países como Alemanha, África do Sul, Argentina, Reino Unido e Suíça.

Uma tentativa de sistematizar a cooperação é criação e códigos modelos, como o projeto de Código Modelo de Cooperação Interjurisdicional para a Ibero-América.

A análise da cooperação jurídica internacional envolve a questão da soberania nacional. O conceito clássico de soberania não serve mais aos dias atuais, no mundo globalizado.

Embora, à primeira vista, possa parecer que a cooperação jurídica internacional e a soberania sejam colidentes, isto não representa uma realidade. Afinal, quando um Estado soberano resolve cooperar, por inúmeros motivos, com o outro, a própria decisão de cooperar e de executar essa cooperação envolve um ato voluntário de parcialmente sacrificar a autodeterminação nacional interna ou externa. Essa autodeterminação constitui uma representação do exercício da soberania.

Diante da pluralidade de sistemas jurídicos existentes entre os Estados nacionais, a soberania pode redundar em uma cooperação desigual, pautada pela obediência a um conjunto de valores de um dos Estados, caso contrário não se realizará. 
No final do século XX, visando reprimir a crescente criminalidade transnacional, houve o fenômeno da juridificação das relações entre os Estados nacionais e, por conseguinte, a normatização da cooperação jurídica. Sendo certo que na formulação destas legislações os Estados levam em conta os direitos humanos.

Existem diversas distinções quanto à cooperação jurídica internacional, sendo que o presente estudo se limita à cooperação ativa, direta ou indireta, no que se refere a obtenção de provas em matéria penal: quebra de sigilo bancário, telefônico, telemático, oitiva de testemunhas, interrogatório, documentos e informações.

O mecanismo jurídico mais tradicional no Brasil de cooperação jurídica internacional em matéria de prova é a carta rogatória, que consiste no veículo de transmissão de qualquer pedido judicial.

Em virtude da morosidade do instrumento da carta rogatória, atualmente, no que se refere à produção de provas, existe o novel auxilio direto, onde se procurou criar meios capazes de operacionalizar com efetividade a apuração dos ilícitos penais e combate a crimes transnacionais.

O direito à prova possui extrema importância no processo penal. A produção da prova e sua admissibilidade deve ser pautada pelo respeito às garantias inerentes ao Justo Processo.

O direto à prova deve ser interpretado de forma ampla, até porque a prova, ou sua inexistência, reverbera não só em face do acusado, mas por toda a sociedade, extrapolando o âmbito do processo. Não se deve confundir fontes de prova, meios de prova e meios de obtenção de prova.

Na busca da verdade atingível, é admissível a utilização de todos os meios lícitos de prova, com participação das partes e do próprio juiz, que não deve se quedar inerte.

Existem limites legais e constitucionais para a busca da verdade atingível, sendo ilícito permitir-se o uso de métodos que violem a dignidade da pessoa humana.

O processo penal garantista impõe limites ao poder do Estado, na persecução penal, limitando-se à busca da verdade atingível ao respeito ao justo processo (fair trial). 
Ao mesmo tempo em que se deve garantir a liberdade na produção de provas, os meios de obtenção de prova e os meios de prova devem ser legítimos e juridicamente admissíveis.

O direito ao justo processo é consagrado universalmente, sendo que o direito à prova é consagrado em diversos tratados internacionais de direitos humanos.

As provas, para serem admitidas no ordenamento jurídico, devem ser pertinentes e relevantes ao deslinde da causa e devem ser produzidas de acordo com as normas legais e princípios constitucionais.

A distinção entre prova ilegítima e ilícita é fundamental para a análise de seus efeitos no processo. A prova ilegítima viola direito processual e será considerada nula, já a prova ilícita, que viola direito material, é inadmissível e deve ser desentranhada dos autos.

Nossa Constituição veda a utilização de provas obtidas por meios ilícitos no processo, sendo certo, entretanto que esta pode vir a ser admitida se for para absolver o acusado.

O procedimento probatório necessita de uma metodologia procedimental ampla, a matéria acerca da legalidade da prova requer uma sistematização com relação a sua origem, conteúdo e relevância, no sentido que se possa aferir acerca de sua licitude, sempre adequando o princípio da busca da verdade atingível com os direitos fundamentais, com a adoção, do princípio da proporcionalidade.

A cooperação jurídica internacional está em contato com uma constelação de Estados, devendo ser feita uma coordenação das opções locais das diversas Nações para que seja viável esta colaboração interestatal, na busca da paz mundial e da preservação das garantias fundamentais universalmente consagradas. A diversidade de sistemas constitui um dos maiores empecilhos à cooperação jurídica internacional em matéria penal.

No campo da cooperação jurídica internacional é dever das nações não só estabeleceram políticas de combate às atividades criminosas, mas também, paralelamente a isso, promover uma padronização sistêmica quanto aos procedimentos processuais e meios de provas, sempre, em última análise, na verificação da verdade atingível, obedecendo o direito à ampla defesa, ao contraditório e à paridade de armas. 
Os problemas de implementação da cooperação jurídica em matéria penal não se limitam à ausência de sistematização, mas também ao desconhecimento dos operadores quanto aos mecanismos existentes e sua tramitação.

A admissibilidade da prova pela via cooperacional pressupõe o respeito aos direitos individuais, ao justo processo, assegurado pelos direitos humanos.

A cooperação jurídica em matéria penal, no âmbito regional, está bem mais desenvolvida na União Europeia, do que no MERCOSUL.

A cooperação jurídica internacional em matéria penal, no que se refere à produção da prova, pode ser feita com a existência de tratados ou sem. O Brasil é signatário de diversos tratados cooperacionais, com inúmeros países, entretanto, embora existam pontos em comum, constata-se uma desarmonia legislativa. V.g. a possibilidade da prova obtida via cooperacional ser utilizada em outros procedimentos, a exigência de dupla incriminação, etc.

Por mais que se deseje cooperar e que, pelo princípio da confiança, o sistema jurídico de outro Estado-Nação deva ser considerado válido, não se há de admitir no Brasil a integração no ordenamento jurídico de meios de provas ou de obtenção de provas que violam a dignidade humana, a intimidade, a vida privada, e os demais direitos individuais, sob pena de se gerar insegurança jurídica e afrontar a ordem pública.

Diante da ausência de linearidade no tratamento e alcance das questões relacionadas às liberdade individuais e ao sigilo bancário, a prova obtida pode ser inadmissível em nosso país.

$\mathrm{Na}$ análise da prova produzida pela cooperação jurídica internacional há que se resguardar o núcleo essencial dos direitos fundamentais.

A cooperação jurídica internacional em matéria penal desenvolveu-se com viés repressivo. No entanto, deve ser utilizada também pela defesa, com eficácia, garantindo-se a almejada paridade de armas, mesmo antes da existência de ação penal.

O respeito aos direitos humanos e as garantias inerentes ao justo processo não constituem um empecilho à cooperação em matéria penal.

Há que se permitir que a defesa possa requerer, com a mesma eficácia que a acusação, a cooperação jurídica internacional, visando a obtenção de meios de prova, meios 
de obtenção de prova ou mesmo provas emprestadas que comprovem sua inocência ou diminuam sua culpabilidade.

Deve-se criar na mentalidade dos aplicadores do direito e dos diplomatas que negociam os tratados cooperacionais, uma visão mais equânime quanto aos direitos da defesa.

Enquanto para a Polícia e para o Ministério Público e para o próprio poder judiciário são criados mecanismos e redes de cooperação, existindo relacionamento direto entre esses órgãos, não se garante a defesa às mesmas possibilidades, ficando esta à margem destes novos indispensáveis instrumentos.

Quiçá a constituição de valores comuns, como os contidos nos direitos humanos, seja capaz de propiciar uma cooperação mais equilibrada, sem que sejam desrespeitadas as diversidades culturais de cada nação. 


\section{BIBLIOGRAFIA}

ABADE, Denise Neves. Direitos fundamentais na cooperação jurídica internacional. Extradição, Assistência Jurídica, Execução de Sentença Estrangeira e Transferência de Presos. São Paulo: Saraiva, 2013.

Abbagnano, Nicola, Dicionário de Filosofia, São Paulo: Martins Fontes, 1998.

ABREU DALLARI, Dalmo de. Elementos de Teoria Geral do Estado. 22 $2^{\mathrm{a}}$ edição, atualizada. São Paulo: Saraiva, 2001. Direitos Humanos e Cidadania. São Paulo: Moderna, 1998.

ACCIOLY, Hildebrando. Manual de Direito Internacional Público. São Paulo: Saraiva, 2005.

ALEXY, Robert, Teoria dos Direitos Fundamentais. SILVA, Virgílio Afonso da (trad.), $2^{\mathrm{a}}$ ed., São Paulo: Malheiros, 2011.

AlbuQuerque Mello, Celso D. de. Curso de Direito Internacional Público, $14^{\mathrm{a}}$ ed., Rio de Janeiro: Renovar, 2002.

ALMEIDA, Fernando Dias Menezes de. $O$ sigilo no sistema democrático in YARSHELL, Flávio Luiz e MORAIS, Mauricio Zanoide de. Estudos em Homenagem à Professora Ada Pellegrini Grinover. São Paulo: DPJ, 2006.

ALMEIDA, Joaquim Canuto Mendes de. Ação Penal. São Paulo: Saraiva, 1938

. A contrariedade na instrução criminal. São Paulo, 1937.

Princípios Fundamentais do Processo Penal. A contrariedade na instrução criminal. O direito de defesa no inquérito policial. Inovações do Anteprojeto de Código de Processo Penal. São Paulo: Revista do Tribunais, 1973.

ALMEIDA, Paulo Roberto. Mercosul: Fundamentos e Perspectivas. São Paulo: LTr, 2000.

ALTAVILA, Jayme de. Origem dos direitos dos povos. São Paulo: Ícone, 1989.

ALVES, Cleber Francisco. O princípio constitucional da dignidade da pessoa humana: o enfoque da doutrina social da igreja. Rio de Janeiro: renovar, 2001.

ALVES, Rogério. "Os Recursos como indicadores as saúde processual. Querem-se vivos ou mortos?" in Que Futuro para o Direito Processual Penal? Simpósio em homenagem a Jorge de Figueiredo Dias, por ocasião dos 20 anos do Código de Processo Penal Português. Portugal: Coimbra Editora, 2009, pp 127-134.

AMBOS, Kai. A Reforma do Processo Penal no Brasil e na América Latina. Método.

LIMA, Marcelo Polastri. O Processo Acusatório e a vedação probatória, Livraria do Advogado. Porto Alegre, 2009.

AMODIO, Ennio. analisando o sistema europeu, in archivio.rivistaaic.it/material/convegni/roma/20021114/amodio.html.

ANDÉCHAGA, Luis Ortúzar. Aplicación Judicial del Derecho Comunitario. Madrid: Trivium, 1992.

ANDRADE, Agenor Pereira. Manual de Direito Internacional Público. São Paulo: Saraiva, 2002 . 
ANDRADE, J.C. VIEIRA DE, A Carta Europeia dos Direitos Fundamentais e as Constituições Nacionais, in Carta de Direitos Fundamentais da União Europeia, Coimbra Editora, Coimbra, 2001.

ANDRADE, J. L., A globalização, o crime organizado e a corrupção, disponível em HTTP/WWW .arbil.org/(65)andr.htm.

ANDREUCCI, Ricardo Antunes. Direito Penal e Criação Judicial. São Paulo: Revista dos Tribunais, 1989.

AN-NA'IM, Abdullahi Ahmed. "Why should Muslims abandon Jihad? Human Rights and the future of internationa Law" in International Law and the Third World. Nova Iorque: Routledge-Cavendish Taylor \& Francis Group, 2010.

ANSELMO, Marcio Adriano, Cooperação Internacional em matéria penal no âmbito do Mercosul - Anatomia do Protocolo de San Luis, in BALTAZAR JÚNIOR e LIMA, Luciano Flores (org.), Cooperação jurídica internacional em matéria penal, Porto Alegre: Verbo Divino, 2010.

ANTOKOLETZ, Daniel. Tratado de Derecho Internacional Público. 2 vols. Buenos Aires: La Facultad, 1951.

AQUINO, José Carlos G. Xavier de. A prova testemunhal no processo penal brasileiro, $4^{\mathrm{a}}$ edição revista e ampliada (capítulo novo sobre a Lei de proteção às vítimas, testemunhas e acusados colaboradores). São Paulo: Editora Juarez de Oliveira, 2002.

ARANHA, Alberto José Q. T. de Camargo. Da prova no processo penal, $5^{\mathrm{a}}$ edição. São Paulo: Saraiva, 1999.

ARAUJO, Nadia de. Cooperação Jurídica Internacional no Superior Tribunal de Justiça. Comentários à Resolução nº 9/2005. Rio de Janeiro, São Paulo, Recife: Renovar, 2010.

A importância da Cooperação Jurídica Internacional para a Atuação do Estado Brasileiro no Plano Internacional in Manual de Cooperação Jurídica Internacional e Recuperação de Ativos. Cooperação em matéria penal. Brasília: Secretaria Nacional de Justiça, 2008.

ARAÚJO, José Laércio. Intimidade, Vida Privada e Direito Penal. São Paulo: Habeas Editora.

ASHWORTH, Andrew. Principles of Criminal Law, $3^{\text {a }}$ edição. Nova Iorque: Oxford University Press, 1999.

ASSIS MOURA, Maria Thereza Rocha de. A Prova por Indícios no Processo Penal, Reimpressão. Rio de Janeiro: Editora Lumen Juris, 2009.

Justa Causa para a Ação Penal - Doutrina e Jurisprudência. São Paulo: Revista dos Tribunais, 2001.

AUGUST, Ray. Public International Law. New Jersey (EUA): Prentice Hall, 1995.

ÁVILA, Humberto. Teoria dos Princípios: da definição à aplicação dos princípios jurídicos. $12^{\mathrm{a}}$ Ed. São Paulo: Malheiros, 2011

AZKOUL, Marco Antonio. A Polícia e sua função constitucional, $1^{\mathrm{a}}$ edição. São Paulo: Oliveira Mendes, 1998.

BACIGALUPO, Enrique. Derecho penal economico. Buenos Aires: Hammurabi, 2004. 
BADARÓ, Gustavo Henrique Righi Ivahy. Ônus da Prova no Processo Penal. São Paulo: Revista dos Tribunais, 2003.

BALTAZAR JÚNIOR, José Paulo; LIMA, Luciano Flores de. Cooperação Jurídica Internacional em matéria penal. Porto Alegre: Verbo Jurídico, 2010.

BARBOSA, Rui. Oração aos Moços, 16 a edição. Rio de Janeiro: Ediouro, 1999.

BARRA, Rubens prestes. Estudos jurídicos, em homenagem a Manoel Pedro Pimentel, São Paulo, Revista dos Tribunais, 1992, p.302.

BARRETO, Ireneu Cabral. A Convenção Europeia dos Direitos do Homem Anotada. $3^{\mathrm{a}}$ ed. rev. e actualizada. Coimbra: Coimbra Editora, 2005.

BARROS, Marco Antonio de. A busca da verdade no processo penal. São Paulo: Revista dos Tribunais, 2002.

BASSIOUNI, M. Cherif. International Criminal Law. New York: Transnational Publishers, Inc, 2000.

BASTOS, Celso Ribeiro e MARTINs, Ives Gandra, Comentários à Constituição do Brasil, $2^{\circ}$ vol., São Paulo: Saraiva, 1989.

BAUM, Lawrence. A suprema corte Americana. Rio de Janeiro: Forense, 1987.

BAXI, Upendra. "What may the 'Third World' expect from International Law?" in International Law and the Third World. Nova Iorque: Routledge-Cavendish Taylor \& Francis Group, 2010.

BECCARIA, Cesare, Dos delitos e das penas. Tradução de Lucia Guidini e Alessandro Berti Contessa, São Paulo: Martins Fontes, 1991.

BECHARA, Fábio Ramazzini. Cooperação Jurídica Internacional em Matéria Penal. Eficácia da prova produzida no exterior. São Paulo: Saraiva, 2011.

BELLI, Benoni, A politização dos direitos humanos. O Conselho de Direitos Humanos das Nações Unidas e as Resoluções sobre Países, São Paulo: Perspectiva, 2009.

BELLOQUE, Juliana Garcia. Sigilo bancário. São Paulo: Revista dos Tribunais, 2003.

BENEVIDES, Maria Victoria de Mesquita; BERCOVICI, Gilberto; MELO, Claudinei de. Direitos Humanos, Democracia e República. São Paulo: Quartier Latin, 2009.

BERTOLINO, Pedro J. El debido proceso penal, La Plata, Platense, 1986.

BILDER, R. B. "Na overview of international human rights law". In: Hannum, H (editor). Guide of International Human Rights Practice, $2^{\mathrm{a}}$ ed. Philadelphia: University of Pennsulvania Press, 1992.

BOBBIO, Norberto; O Terceiro Ausente. Ensaios e discursos sobre a paz e a guerra. (trad.) Daniela BeccacciaVersiani, (org.) PeitroPolito; prefacio da edição brasileira Celso Lafer, Barueri: Manole, 2009.

Direito e Estado no pensamento de Emanuel Kant, 4ª edição. Brasília: UNB, 1997.

Liberalismo e Democracia. Tradução de Marco Aurélio Nogueira, $3^{a}$ edição. São Paulo: Brasiliense, 1990.

A Era dos direitos. Rio de Janeiro: Campus, 1992. 
BOGGIANO, Antonio. Teoria del derecho internacional - las relaciones entre los ordenameientos jurídicos. Buenos Aires: La ley, 1996.

BOSON, Gerson de Brito. Direito Internacional Público O Estado em Direito das Gentes. Belo Horizonte: Del Rey, 2002.Cambridge University Press, 1999.

BOOTH, Ken e outros. Human Rights in Global Politics.

BOURGEOIS, L. La solidarité, in Abbagnano, Nicola, Dicionário de Filosofia. São Paulo: Martins Fontes, 1998.

BOULOC, Bernard; BEDO, Réginald de; LEGROS, Pierre. Le droit au silence et la détention provisoire. Bruxelas: Bruylant, 1997.

BRITO, Wladimir. "Processo Penal Internacional" in: Que Futuro para o Direito Processual Penal? Simpósio em homenagem a Jorge de Figueiredo Dias, por ocasião dos 20 anos do Código de Processo Penal Português. Portugal: Coimbra Editora, 2009, pp 207-246

BROOKS, Peter. Troubling confessions. Chicago: Chicago Press, 2000.

BULOS, Uadi Lammêgo, Curso de Direito Constitucional. $6^{\mathrm{a}}$ ed., ver. atual. São Paulo: Saraiva, 2011;

BUENO, José Antonio Pimenta. Apontamentos sobre o Processo Criminal Brasileiro. $2^{\mathrm{a}}$ edição. Rio de Janeiro: Empreza Nacional do Diário, 1857.

CAMPILONGO, Celso Fernandes. $O$ direito na sociedade complexa. São Paulo: Max Limonad, 2000.

CANOTILHO, José Joaquim Gomes. Direito Constitucional e teoria da Constituição, $7^{\mathrm{a}}$ edição. Coimbra: Almedina, 2003.

Estudos sobre Direitos Fundamentais. Coimbra e São Paulo: Coimbra Editora e Revista dos Tribunais, 2008.

CAPEL, José Sáez. Seguridad, proceso penal y derechos humanos en America latina y el caribe. Buenos Aires: Proa XXI, 2004.

CARNELUTTI, Francesco. As Misérias do Processo Penal. Tradução de José Antonio Cardinalli, São Paulo: Conan, 1995.

La prueba civil, Niceto Alcalá-Zamora y Castilho (trad.), Buenos Aires: Depalma, 1979.

CARVALHO RAMOS, André de. Direitos humanos na integração econômica, São Paulo: Renovar, 2008.

"O diálogo das cortes: O Supremo Tribunal Federal e a Corte Interamericana de Direitos Humanos" in AMARAL JUNIOR, Alberto do; JUBILUT, Liliana Lyra. O STF e o direito internacional dos direitos humanos. São Paulo: Quartier Latin, 2009

Processo Internacional de Direitos Humanos. Rio de Janeiro: renovar, 2002.

Paulo: Renovar, 2004.

Responsabilidade internacional por violações de direitos humanos. São

CARVAlHO, Salo de. A Política Criminal de Drogas No Brasil - Estudo Criminológico e Dogmático, $4^{\mathrm{a}}$ edição, ampliada, atualizada e com comentários à Lei 11.343/06. Rio de Janeiro: Lumen Juris, 2007. 
CASELlA, P. B.; SANCHES, R. E. (org.), Cooperação judiciario internacional. 1., Forense, Rio de Janeiro, 2005.

CASTILHO, Ela Wiecko V. de. "Cooperação Internacional na execução da pena: a transferência de presos"in Revista Brasileira de Ciências Criminais 71, Instituto Brasileiro de Ciências Criminais. São Paulo, 2008.

CASTILHO, Ricardo. Direitos Humanos, Saraiva. SãoPaulo, 2010.

CASTRO, Carlos Roberto Siqueira. A constituição aberta e os direitos fundamentais, $2^{\text {a }}$ edição, Forense: Rio de Janeiro, 2010.

CATENA, Victor M. Moreno. El secreto em La prueba de testigos Del proceso penal. Madri: Montecorvo, 1980.

CAVARÉ, Louis. Le Droit International Public Positif. 2 vols. Paris: A. Pedone, 1951.

CENEVIVA, Walter. Segredos profissionais, São Paulo, Malheiros. 1996;

CERVINI, Raúl, Tavares. Juarez, Princípios da cooperação judicial penal internacional no protocolo do Mercosul. São Paulo: RT, 2000.

CERVINI, Raúl. "Tóxicos - Criminalidad Organizada: Su dimension econômica” in Justiça Penal - 3: Críticas e Sugestões - O Crime Organizado (Itália e Brasil). A Modernização da Lei Penal, $1^{\text {a }}$ edição. São Paulo: Revista dos Tribunais, 1995, pp 117-148.

CLÈVE, Clêmerson Merlin e FREIRE, Alexandre Reis Siqueira, Algumas Notas Sobre Colisão de Direitos Fundamentais, in GRAU, Eros Roberto e CunHA, Sérgio Sérvulo da (coord.). Estudos de Direito Constitucional em Homenagem a José Afonso da Silva. da (Org.). Estudos de direito constitucional em homenagem a José Afonso da Silva. São Paulo:Malheiros, 2003.

CHAZOURNES, Laurence Boisson de e SANDS, Philippe. International Law, the International Court of Justice and Nuclear Weapons. Cambrige: Cambridge University Press, 1999.

CHIAVARIO, Mario e outros. Procedure Penali D'Europa. Itália: Cedam, 2001.

CHIMENTI, Francesco, O processo penal e verdade material: teoria da prova. Rio de Janeiro: Forense, 1995.

CHOUKR, Fauzi Hassan. "O relacionamento entre o Ministério Público e a Polícia Judiciária no processo penal acusatório” in Processo Penal e Estado de Direito. Campinas: Edicamp, 2002.

Estudos do Processo Penal. O Mundo à Revelia, $1^{\text {a }}$ edição. Campinas: Agá Juris, 2000.

A convenção Americana dos Direitos dos Humanos e o Direito Interno Brasileiro. Bauru: Edipro, 2001.

Processo Penal à luz da constituição, São Paulo: Filiada, $1^{\text {a }}$ ed., 1999.

CHOUKR, Fauzi Hassan e AMBOS, Kai. Tribunal Penal Internacional. São Paulo: Revista dos Tribunais, 2000.

CINTRA, Antonio Carlos de Araújo; GRINOVER, Ada Pellegrini; DINAMARCO, Cândido Rangel. Teoria Geral do Processo. $18^{\mathrm{a}}$ ed., Malheiros, 2002, São Paulo COELHO, 
Rodrigo Meirelles Gaspar. Proteção Internacional dos direitos humanos. Curitiba: Juruá, 2007.

COLOMBER, Juan-Luis Gómez, A investigação criminal Problemas atuais e perspectivas e Unificação Internacional, in CHOUKR, Fauzi Hassan e AMBOS, Kai (cord.), CHOUKR, Fauzi Hassan (trad.), Processo penal e estado de direito, Campinas: Edicamp, 2002.

COMAPARATO, Fabio Conder. A afirmação histórica dos direitos humanos, $2^{\mathrm{a}}$ ed., São Paulo: Saraiva, 2001.

CORDANI, Dora Cavalcanti. "Cooperação Jurídica Internacional em matéria penal no Brasil” in Crimes Econômicos e Processo Penal. São Paulo: Saraiva, 2008.

CORREIA, Theresa Rachel Couto. Corte Internacional Americana de Direitos Humanos. Repercussão Jurídica das Opiniões Consultivas Curitiba: Juruá, 2008.

COSTA ANDRADE, Manuel da. "Métodos Ocultos de Investigação (Plädoyer para uma Teoria Geral)" in Que Futuro para o Direito Processual Penal? Simpósio em homenagem a Jorge de Figueiredo Dias, por ocasião dos 20 anos do Código de Processo Penal Português. Portugal: Coimbra Editora, 2009, pp 525-551.

Coimbra,2006.

Sobre as proibições de prova em processo penal. reimpressão, Portugal:

COSTA, José Augusto Fontoura. Normas de Direito Internacional Aplicação Uniforme do Direito Uniforme. São Paulo: Atlas, 2000.

COSTA, Paula Bajer Fernandes Martins da. Igualdade no Direito Processual Penal Brasileiro. São Paulo: Revista dos Tribunais, 2001

COSTA JUNIOR, Paulo José. Agressões à Intimidade - O espisódio Lady Di. São Paulo: Malheiros, 1997.

CRETELLA JUNIOR, José. Comentários à constituição brasileira de 1988, Rio de Janeiro, Forense Universitária, 1990, v. I; $2^{a}$ ed.,1991, v. II;

CRUZ, Gabriel Dias Marques da. Arguição de descumprimento de preceito fundamental. São Paulo: Malheiros, 2011.

CUNHA, José Damião da. "Ne Bis in Idem e Exercício da Acção Penal” in :Que Futuro para o Direito Processual Penal? Simpósio em homenagem a Jorge de Figueiredo Dias, por ocasião dos 20 anos do Código de Processo Penal Português. Portugal: Coimbra Editora, 2009, pp 553-581.

CUNHA, J.S. Fagundes e BALUTA, José Jairo. O Processo Penal à Luz do Pacto de São José da Costa Rica. A vigência e supremacia sobre o direito interno brasileiro (dec. 678/92). Curitiba: Juruá, 1997

CUNHA, Paulo Ferreira da. "Processo Penal, Rito e Magia. Desafios de Ontem e de Hoje" in Que Futuro para o Direito Processual Penal? Simpósio em homenagem a Jorge de Figueiredo Dias, por ocasião dos 20 anos do Código de Processo Penal Português. Portugal: Coimbra Editora, 2009, pp 371-381.

DALLARI, Pedro B. A. Constituição e tratados internacionais. São Paulo: Saraiva, 2003. 
DAVID, René. Os grandes sistemas do direito contemporâneo. São Paulo: Martins Fontes, 1996.

DAVIES, Malcom, CROALL, Hazel and TYRER, Jane. Criminal Justice: An Introduction to the Criminal Justice System in England and Wales, Second Edition. London and New York: Longman, 1998.

DELAMS-MARTY, Mireille. Processo Penal e Direitos do Homem. Barueri: Manole, 2004.

DELMANTO JUNIOR, Roberto. Coleção Estudos de Processo Penal Prof. Joaquim Canuto Mendes de Almeida v. 7 - Inatividade no Processo Penal Brasileiro. São Paulo: Revista dos Tribunais, 2004.

DESPREZ, François. Rituel Judiciaire et procès penal. Paris: Lextenso, 2009.

RAMOS, Vânia Costa. O Direito à Não Auto-Inculpação no Processo Penal e ContraOrdenacional Português. Coimbra: Coimbra Editora, 2009.

DEZEN, Guilherme Madeira. Da prova penal. Tipo processual, provas típicas e atípicas. Atualizado de acordo com as Leis 11.689, 11.690/08 e 11.719/08. Campinas: Millenium, 2008.

DIMOULIS, Dimitri; MARTINS, Leonardo. Teoria geral dos direitos fundamentais., $3^{\mathrm{a}}$ edição. São Paulo: Revista dos Tribunais, 2011.

DINAMARCO, Candido Rangel, Instituições de Direito Processual Civil. São Paulo: Malheiros, 2001.

DIP, Ricardo Henry Marques. "Breves Apontamentos sobre o Pacto de São José da Costa Rica" in Justiça Penal Críticas e Sugestões -6. 10 Anos da Constituição e a Justiça Penal, Meio Ambiente, Drogas, Globalização, O Caso Pataxó. São Paulo: Revista dos Tribunais, 1999.

DIREITO, Carlos Alberto. O Estado Moderno e a Proteção dos Direitos do Homem. Rio de Janeiro: Freitas Bastos, 1968.

DIZ, F. M., Instrumentos jurídicos de Cooperación Judicial Penal em La Unión Europea. In: BELMONTE, C. P; MELGARE, P. (Coord). O direito na sociedade contemporânea: estudos em homenagem ao Ministro José Neri da Silveira. 1., Rio de Janeiro: Forense, 2005.

DOLINGER, Jacob. Direito Internacional privado - parte geral. Rio de Janeiro: Renovar, 2001.

DÓMINE, María Celilia. "El terrorismo internacional: um análisis comparado de la nueva legislación antiterrorista y de La actual política criminal" in Revista Brasileira de Ciências Criminais 75, Instituto Brasileiro de Ciências Criminais. São Paulo, 2008.

DOTTI, René Ariel, Princípios do processo penal. Palestra apresentada em Assunção em jul/92, por ocasião do Seminário do XIV Congresso de Ass. Internacional de Direito Penal, Fasc. Ci. Penais. Porto Alegre, v. 6, nº1, p.89, jan/mar 1993.

DUARTE, Antonio Gomes. “Do Inquérito à Denúncia. Pará: Editora Cejup, 1996.

ESCOBAR, Raúl Tomás. El Interrogatorio em La Investigación Criminal. Confesión y torturas. Ritos y sectas. Técnicas para la investigación del delito. Psicologia, 
Sociologia, Psicopatologia, Parapsicologia, Tercera edición actualizada. nacionales. Buenos Aires: Editorial Universidad, 1996.

EDWARDS, Carlos Enrique. Garantías Constitucionales en Materia Penal. Libertad personal. Principio de legalidad. Garantías procesales. La pena y su ejecución. Aplicación de los tratados internacionales. Buenos Aires: Astrea, 1996.

ESER, Albin. Sobre La exaltación del bien jurídico a costa de La víctima, $1^{\mathrm{a}}$ edição. Tradução de Manuel Cancio Meliá. Bogotá: Universidad Externado de Colombia, 1998.

ESMEIN, Adhémar. Histoire de la procédure criminelle em France - et spécialement de La rpocédure inquisitoire, depuis Le XIII siécle jusqu'a nos jours. Paris: Panthéon-Assas, 2010.

ESPÍNOLA, Eduardo. Elementos de Direito Internacional Privado, Rio de Janeiro: Ribeiro dos Santos.

ESTELLITA, Heloísa. Criminalidade da empresa, quadrilha e organização criminosa. Porto Alegre: Livraria do advogado, 2009.

FALK, Richard. "International Law and the Future" in International Law and the Third World. Nova Iorque: Routledge-Cavendish Taylor \& Francis Group, 2010.

FARAH, José Antonio; LIMA, Lopes de. Constituição européia e soberania nacional. Leme: Mizuno, 2006.

FARIA COSTA, José de. Direito Penal e Globalização. Reflexões não locais e pouco globais, $1^{\circ}$ edição. Portugal: Coimbra, 2010.

FERNANDES, Antonio Scarance. "Crime Organizado e a Legislação Brasileira” in Justiça Penal - 3: Críticas e Sugestões - O Crime Organizado (Itália e Brasil). A Modernização da Lei Penal, $1^{\text {a }}$ edição. São Paulo: Revista dos Tribunais, 1995, pp 31-56.

O Processo Penal Internacional, in CASELLA, Paulo Borba, Celi Jr. e outros, Direito Internacional, Humanismo e Globalidade, São Paulo: Atlas, 2008.

$\mathrm{O}$ equilíbrio na investigação criminal, in Estudos em homenagem à Professora Ada Pellegrini Grinover, YARSHAL, Flávio Luiz e ZANOIDE, Mauricio de, São Paulo: DPJ editora, 2005.

$\mathrm{O}$ equilíbrio entre a eficiência e o garantismo e o crime organizado in Revista Brasileira de Ciências Criminais 70, Instituto Brasileiro de Ciências Criminais. São Paulo, 2008.

O equilíbrio na repressão ao crime organizado In FERNANDES, Antonio Scarance; ALMEIDA, José Raul Gavião de; MORAES, Maurício Zanoide. Crime organizado - aspectos processuais. São Paulo: Revista dos Tribunais, 2009.

Tribunais, 2000.

Processo Penal Constitucional, $2^{\mathrm{a}}$ edição. São Paulo: Revista dos

Teoria Geral do procedimento e procedimento no processo penal, São Paulo: Revista dos Tribunais, 2008. 
Tipicidade e sucedâneos da prova, in Provas no processo penal. Estudo comparado.AntonioScarance Fernandes, José Raul Gavião de Almeida, Maurício Zanoide de Moraes (coord.), São Paulo: Saraiva, 2011.

Prova e sucedâneos da prova no processo penal (Extraído do relatório para a XX Jornadas Ibero americanas de direito processual penal em Málaga, Espanha 2006), in Revista Brasileira de Ciências Criminais, São Paulo: RT, nº 66, maio/junho de 2007.

FERNANDES, Francisco. Dicionário de Sinônios e Antônimos de língua portuguesa, $7^{\mathrm{a}}$ edição. São Paulo: Globo, 1998.

FERRAJOLLI, Luigi, Direito e Razão. Teoria do Garantismo Penal, $2^{a}$ edição. São Paulo: Revista dos Tribunais, 2006.

Garantismo. Una Discusión sobre Derecho Y Democracia. Tradução de Andrea Greppi. Madrid: Editorial Trotta, 2009.

Uma discusión sobre derechoyu democracia. $2^{\mathrm{a}}$ ed., Madrid: Trotta, 2009 e, do mesmo autor Direito e Razão. Teoria do Garantismo Penal, $6^{\mathrm{a}}$ ed., Ana Paula Zomer, Fauzi Hassan ChOuKR, JuaresTAVARES e Luis Flávio GoMES (trad.), São Paulo: RT, 2000.

FERREIRA FILHO, Gonçalves: Direito Constitucional Internacional, $2^{\mathrm{a}}$ ed., Renovar, Rio de Janeiro, 2000.

FERREIRA FILHO, Manoel Gonçalves Ferreira. "A concretização dos princípios constitucionais no Estado Democrático de Direito" in Estudos em Homenagem à Professora Ada Pellegrini Grinover. São Paulo: DPJ, 2006.

FIGARO, André Domingues. Comentários à reforma do judiciário, São Paulo: Premer Máxima, 2005.

FIGUEIREDO DIAS, Jorge de. Questões Fundamentais do Direito Penal Revisadas. São Paulo: Revista dos Tribunais, 1999.

Clássicos Jurídicos. Direito Processual Penal, $1^{\mathrm{a}}$ edição. Portugal: Coimbra Editora, 2004.

FIGUEIREDO STEINER, Sylvia Helena de. A Convenção Americana sobre Direitos Humanos e sua Integração ao Processo Penal Brasileiro. São Paulo: Revista dos Tribunais, 2000.

FLETCHER, George P.; OHLIN, Jens D.. Defendiendo a la Humanidad. Buenos Aires: Hammurabi, 2009.

FLORIAN, Eugenio. De lãs pruebas penales, Tomo I. Santa Fé de Bogotá: Temis, 1998.

FRANCO SOBRINHO, Manuel de Oliveira. Afirmações na prática do Direito Internacional. Rio de Janeiro: Imprensa Nacional, 1960.

FOSTER, Nigel. Fosteron EU Law, $3^{\mathrm{a}}$ edição. Nova Iorque: Oxford, 2011.

FUX, Luiz; NERY JR, Nelson; WAMBIER, Teresa Arruda Alvim. Processo e Constituição. São Paulo: Revista dos Tribunais, 2006.

GALINDO, George Rodrigo Bandeira. Tratados Internacionais de direitos humanos e constituição brasileira. Belo Horizonte: Del Rey, 2002. 
GEMAQUE, Silvio Cesar Aroucki. A necessária influência do Processo Penal Internacional no Processo Penal Brasileiro. Tese de doutorado. São Paulo: Universidade de São Paulo, 2010.

GIACOMOLLI, Nereu José. Legalidade, oportunidade e consenso no processo penal. Porto Alegre: Livraria do advogado, 2006.

GINTNER, Luiz José. Em busca de Liliput. 2. ed. - Rio de Janeiro: Litteris, 1997.

GLENNY, Misha. MacMáfia. Crime sem fronteiras. São Paulo: Companhia das Letras, 2008.

GOLOMER, Juan-Luis Gómez. A investigação criminal - Problemas atuais e perspectivas de unificação internacional. in Processo Penal e Estado de Direito. Campinas: Edicamp, 2002, pp 199-244.

GOMES, Luiz Flávio; PIOVESAN, Flávia $O$ sistema interamericano de proteção dos direitos humanos e o direito brasileiro. São Paulo: Revista dos Tribunais, 2000.

GOMES, Luiz Flávio. Estudos de Direito Penal e Processo Penal, $1^{\text {a }}$ edição, $2^{\mathrm{a}}$ tiragem. São Paulo: Revista dos Tribunais, 1999.

GOMES FILHO, Antonio Magalhães. A Motivação das Decisões Penais. São Paulo: Revista dos Tribunais, 2001.

Notas sobre a terminologia da prova (reflexos no processo penal brasileiro) in Estudos em Homenagem à Professora Ada Pellegrini Grinover. São Paulo: DPJ, 2005.

Direito a Prova no Processo Penal. São Paulo: Revista dos Tribunais, 2007.

Tribunais.

Escritos em Homenagem a Alberto Silva Franco. São Paulo: Revista dos

Breves Anotações Sobre a Temática das Provas no Projeto de Código de Processo Penal (Projeto $\mathrm{n}^{\circ} 156 / 2009$ do Senado Federal), in Revista do Advogado $\mathrm{n}^{\circ}$ 113, AASP, 2011.

GONÇALVES, Flávio José Moreira. Notas para a caracterização epistemológica da teoria dos direitos fundamentais in Dos Direitos Humanos aos Direitos Fundamentais, Livraria do advogado. Porto Alegre, 2007.

GRAU, Eros Roberto; CUNHA, Sérgio Sérvulo da. Estudos de direito constitucional. São Paulo: Malheiros, 2003.

GRECO FILHO, Vicente. Interceptação telefônica, 2a edição. São Paulo: Saraiva, 2005.

Tutela Constitucional das Liberdades. São Paulo: Saraiva, 1989.

Manual de Processo Penal, $7^{\mathrm{a}}$ edição, revista, atualizada e ampliada com a colaboração de João Daniel Rassi. São Paulo: Saraiva, 2009.

GRECO, Alessandra Orcesi Petro. A prova penal no contexto da dignidade da pessoa humana. In: Revista do Advogado ${ }^{\circ}$ 99. Associação dos Advogados de São Paulo - AASP. 20 anos da Constituição. Ano XXVII. Setembro de 2008.

GRINOVER, Ada Pellegrini. O processo constitucional em marcha. São Paulo: Max Limond, 1985. 
Interrogatório do réu e direito ao silêncio. Ciência Penal, São Paulo, v.3, n.1, p.15-31, 1976.

Processo Penal Transnacional: linhas evolutivas e garantias processuais, in Revista Brasileira de Ciências Criminais. Ano 3, no. 9. janeiro - março, 1995.

FERNANDES, Antonio Scarance; GOMES FILHO, Antonio Magalhães. As nulidades no processo penal, 12a edição. São Paulo: Revista dos Tribunais, 2011.

O processo em sua unidade, São Paulo, Saraiva, 1978.

GUERRA, Sidney. Curso de Direito Internacional Público, $7^{\mathrm{a}}$ ed., São Paulo: Saraiva, 2013.

Direitos Humanos. Curso Elementar, São Paulo: Saraiva, 2013.

Liberdades públicas e processo penal-as interceptações telefônicas. $2^{\mathrm{a}}$ ed. São Paulo: RT, 1982.

GUERRA FILHO, Willis Santiago. A filosofia do direito aplicada ao direito processual e à teoria da constituição. São Paulo: Atlas, 2001.

Direitos fundamentais, processo e princípio da proporcionalidade in Dos Direitos Humanos aos Direitos Fundamentais. Livraria do advogado. Porto Alegre, 2007.

GUERREIRO, A; Cooperação penal no Mercosul. Seminário da Escola Superior do Ministério Público Federal realizado no Rio Grande do Sul, out. 2001.

HABERLE, Peter. Estado constutucional cooperativo. Trad. De Marcos Maliska e Elisete Antoniuk. Rio de Janeiro: Renovar, 2007.

HÄBERLE, Peter. MALISKA, Marcos Augusto e ANTONIUK, Elisete (trad.), Estado Constitucional Cooperativo, Rio de Janeiro, São Paulo e Recife: Renovar, 2007.

HASSEMER, Winfried. Direito Penal Libertário. Tradução de Regina Greve; coordenação e supervisão de Luiz Moreira. Belo Horizonte: Del Rey, 2007.

HESSE, Konrad. Temas fundamentais do direito constitucional. São Paulo: Saraiva, 2009.

HOLLIS, Martin; SMITH, Steve. Explaining and understanding international relations. Nova Iorque: Clarendon Press, 2011

ILLUMINATI, Giulio, Responsabile dell' unità di ricerca, in www.ricaritaliana.it/prin/unita_op-2005122029_htm.

JACKSON, Vicki. Transnational challenges to constitutional Law: convergence, resitance, engagement in Federal Law Review, vol. 35, 2007, pp. 161-186.

JAKOBS, Günther. Ciencia del Derecho: técnica o humanística? $1^{\mathrm{a}}$ edição. Bogotá: Universidad Externado de Colombia, 1996.

JO, Hee Moon. Introdução ao Direito Internacional. São Paulo: LTr, 2000.

JORGE, Manuel e NeTO, SILVA. O princípio da máxima efetividade e a interpretação constitucional.São Paulo: LTr, 1999.

KAPLAN, Morton. KATZEMBACH, Nicholas. Fundamentos Políticos del Derecho Internacional. México-DF: Limusa-Wiley, 1965.

KELSEN, H. Princípios do direito internacional. Ijuí: Unijuí, 2010 
KLEEBANK, Susan. Cooperação judiciária por via diplomática: avaliação e propostas de atualização do quadro normativo. Brasília: Instituto Rio Branco. Fundação Alexandre de Gusmão, 2004.

KLIKSBERG, Bernardo. Mitos e realidades sobre a criminalidade na América latina. in Revista Brasileira de Ciências Criminais 73, Instituto Brasileiro de Ciências Criminais. São Paulo, 2008.

KLOEPFER, Michael, Os direitos fundamentais da lei fundamental: sucessos, fraquezas, tarefas para o futuro. in. LEITE, Jorge Salomão; SARLET, Igo Wolfgang e CARBONELL, Miguel (Cord.). Direitos Deveres e Garantias Fundamentais. Salvador: Jus PODIVM, 2011.

KRIELI, Martin. Introducción a la teoria del Estado. trad. Eugênio Bulygin, Buenos Aires: Depalma, 1980.

KYMLICKA, Will, Multiculturalismo Liberal e Direitos Humanos, in SARMENTO, Daniel, IKAWA, Daniela e PIOVESAN, Flávia (cord.). Igualdade, Diferença e Direitos Humanos, $2^{\text {a }}$ tiragem, Rio de Janeiro: Lumen Juris, 2010.

LAFER, Celso. A Internacionalização dos Direitos Humanos: Constituição, racismo e relações internacionais. São Paulo: Manole, 2005.

1998.

. A reconstrução dos direitos humanos. São Paulo: Companhia das Letras,

Declaração Universal dos Direitos Humanos (1948), in MAGNOLI, Demétrio (org.), História da Paz: Os Tratados que desenharam o planeta. São Paulo: Contexto, 2008.

LEITE, Inês Ferreira. O Conflito de Leis Penais. Natureza e Função do Direito Penal Internacional, Portugal: Coimbra Editora, 2008.

LEOWENSTEIN, Karl, Soveringnty and International Co-operation, in The American Journal of International Law, vol. 48, no 2, apr., 1957, p 222/244. www.jstor.org.stable/2194372.

LEWANDOSwsKI, Enrique Ricardo, "Globalização e Soberania", in Direito Internacional, Humanismo e Globalidade, org. Guido Fernando Silva Soares, Paulo Borba Casella et al, São Paulo: Atlas, 2008.

LIMA, Luciano Flores de e ARAS, Vladimir. BALTAZAR JÚNIOR, José Paulo e LIMA, Luciano Flores de (org.). Cooperação Internacional Direta pela Polícia ou Ministério Público, in Cooperação Jurídica Internacional em Matéria Penal. Curitiba: Verbo Divino, 2010.

LIMA, Marcellus Polastri; SANTIAGO, Nestor Eduardo Araruna. A renovação processual penal após a constituição de 1998. Rio de Janeiro: Lumen Juirs, 2009.

As provas vedadas no processo penal brasileiro-vedação de produção e eventual possiblidade de sua utilização, in AMBOS, Kai, LIMA e Marcellus Pastri, $O$ processo acusatório e a vedação de probatória. Perante as realidades alemã $e$ brasileira, com a perspectiva brasileira já de acordo com a reforma processual de 2008. Leis 11.6.89, 11.690 e 11.719, Porto Alegra: Livraria do Advogado, 2009.

LIMA, Maria Rosynete Oliveira. Devido Processo Legal. Porto Alegre: Sergio Antonio Fabris Editor, 1999. 
LITRENTO, Oliveiros. Manual de Direito Internacional Público. 2. ed. Rio de Janeiro: Forense, 1979.

LLANES, Oscar B. Direito Internacional Público Instrumento das Relações Internacionais. Brasília-DF: Horizonte editora, 1978.

LOPES JR., Aury. Introdução crítica ao processo penal. Rio de Janeiro: Lumes Juris, 2010.

(Re)descobrindo as teorias acerca da natureza jurídica do _ processo (penal) in Revista Brasileira de Ciências Criminais 75, Instituto Brasileiro de Ciências Criminais. São Paulo, 2008.

O interrogatório online no processo penal: entre a assepsia judiciária e o sexo virtual. Boletim IBCCRIM. São Paulo, v.13, n.154, p. 6-7, set. 2005.

Direito Processual Penal e sua Conformidade Constitucional, $3^{\mathrm{a}}$ ed., Rio de Janeiro: Lumen Juris, 2010.

LOPES JR., Aury e BADARÓ, Gustavo Henrique. Direito ao Processo Penal no Prazo Razoável, $2^{a}$ edição revisada e atualizada com as leis. Rio de Janeiro: Lumes Juris, 2009.

LOSANO, Mario G. Os grandes sistemas jurídicos: introdução aos sistemas jurídicos europeus e extra-europeus. Tradução de Marcela Varejão. Revisão da tradução de Silvana Cobucci Leite. São Paulo: Martins Fontes, 2007.

Uma carta fundamental: para a União Européia: Constituição ou Tratado? in Mesquita Benevides, Maria Victoria de, Bercovici, Gilberto e Melo, Claudineu de (org.), Direitos humanos, democracia e república. Homenagem a Fábio Konder Comparato, São Paulo: Quartier Latin, 2009.

LOUREIRO, Flávia Noversa. "A (I)Mutabilidade do Paradigma Processual Penal Respeitante aos Direitos Fundamentais em Pleno Século XXI" in Que Futuro para o Direito Processual Penal? Simpósio em homenagem a Jorge de Figueiredo Dias, por ocasião dos 20 anos do Código de Processo Penal Português. Portugal: Coimbra Editora, 2009, pp 269-289.

LUZ, Nelson Ferreira da. Introdução ao Direito Internacional Público. São Paulo: Saraiva, 1963.

MACHADO, Maíra Rocha. Internacionalização do direito penal. A gestão de problemas internacionais por meio do crime e da pena, $1^{\text {a }}$ edição. São Paulo: Editora 34/Edesp, 2004.

Cooperação Penal Internacional no Brasil: as cartas rogatórias passivas. In Revista Brasileira de Ciências Criminais 53, março-abril, 2005.

Machado, Maria Costa Neves, Direito à Diferença Cultural. A igualdade e a diversidade cultural dos seres humanos. O direito à diferença cultural na atualidade. Curitiba: Juruá, 2010.

MADLENER, Kurt. "Meios e Métodos para Alcançar-se no Processo Penal as Metas de "Prazo Razoável" e de "Celeridade". Observações a Respeito da Justiça Alemã " in Que Futuro para o Direito Processual Penal? Simpósio em homenagem a Jorge de Figueiredo Dias, por ocasião dos 20 anos do Código de Processo Penal Português. Portugal: Coimbra Editora, 2009, pp 645-670. 
MADRUGA, Antenor. O Brasil e a jurisprudência do STF na Idade Média da Cooperação Jurídica Internacional, in: sitio da internet: www. rogatória.com.br.

Cooperação e Assistência Jurídica Internacional, in http://www.conjur.com.br/2011-out-19/cooperacao-internacional-cooperacaoassistencia-juridica-internacional

MAGALHÃES GOMES. Mariangela Gama de, O princípio da proporcionalidade no processo penal, São Paulo: Revista dos Tribunais, 2003.

MAGNOLI, Demétrio et al. História da paz. São Paulo: Editora Contexto, 2008.

Relações Internacionais - teoria e história. São Paulo: Saraiva, 2004.

MAIER, Julio B. J. Derecho Procesal Penal, I- fundamentos, $2^{\text {a }}$ edição. Buenos Aires: Editores Del puerto, 1992.

MAIER, Pauline. Making the declaration od independence. Nova Iorque: Alfred A. Knopf, 1997.

A Ética Judicial no Trato Funcional com as Associações Criminosas que seguem o Modelo Mafioso in Justiça Penal - 3: Críticas e Sugestões - O Crime Organizado (Itália e Brasil). A Modernização da Lei Penal, $1^{\text {a }}$ edição. São Paulo: Revista dos Tribunais, 1995, pp 77-88.

MALAN, DIOGO RUDGE. Direito ao confronto no processo penal. Rio de Janeiro: Lumen Iuris, 2009.

MALARINO, Ezequiel, AMBOS, Kai. Persecução Penal Internacional na América Latina e Espanha. São Paulo: Tradução e Organização IBCCrim:, 2003.

MALATESTA, Nicola Framarino dei. A lógica das provas em matéria criminal, dois volumes. São Paulo: Saraiva, 1960.

MALCHER, J.L. da Gama. Manual de Processo Penal, $3^{\text {a }}$ edição. São Paulo: Freitas Bastos, 2009.

MANS, J. M. Los princípios generales del derecho. Barcelona: Bosch, 1979.

MARQUES, Claudia Lima. Conflitos de convenções de processo civil internacional: por um diálogo das fontes universais e regionais do Mercosul in Estudos em Homenagem à Professora Ada Pellegrini Grinover. São Paulo: DPJ, 2006.

MARQUES, José Frederico. Da Competência em Matéria Penal. Campinas: Milennium, 2005.

MARQUES, José Frederico, Elementos de Direito Processual Penal, vol. II, Campinas: Bookseller, 1997.

MARTINS, Ives Gandra da Silva; MENDES, Gilmar Ferreira. Controle concentrado de constitucionalidade, $2^{\text {a }}$ edição. São Paulo: Saraiva, 2007.

MARTINS NETO, João dos Passos. Direitos Fundamentais: Conceito, função e tipos. Revista dos Tribunais: São Paulo, 2003.

MAZZUOLI, Valério de Oliveira. Tratados Internacionais de Direitos Humanos e Direito Interno. São Paulo: Saraiva, 2010.

Coletânea de Direito Internacional, 3 ed. São Paulo: Revista dos Tribunais, 
GOMES, Luiz Flávio. Direito Supraconstitucional. São Paulo: Revista dos Tribunais, 2010.

MEDEIROS, Ana Letícia B. Duarte. Direito Internacional dos Direitos Humanos na América Latina: uma reflexão filosófica da negociação da alteridade. Rio de Janeiro: Lumen Juris, 2007.

MELLO, Celso Albuquerque. Curso de Direito Internacional Público. 2 vols. Rio de Janeiro: Freitas Bastos, 2001.

MELlO, Celso D. de Albuquerque. Curso de Direito Internacional Público. Rio de Janeiro/ São Paulo: Renovar, 2002.

2000 .

Direito Constitucional Internacional, $2^{\mathrm{a}}$ edição. Rio de Janeiro: Renovar,

MELLO, Rodrigo Pereira de. Provas Ilícitas e sua interpretação constitucional. Porto Alegre: Saft, 2000.

MENDES DA SILVA, RICARDO PERLINGEIRO, Auxílio direto, carta rogatória e homologação de sentença estrangeira. in, Revista de Processo, v. 30, n. 128, p.287-292, out

MENDES, Gilmar Ferreira; BRANCO, Paulo Gustavo Gonet. Curso de Direito Constitucional. $6^{\text {a }}$ edição, São Paulo: Saraiva, 2011

. Proteção Judicial Efetiva dos Direitos Fundamentais. In. Direitos Fundamentais em Estado Constitucional. Estudos em homenagem a J.J. Gomes Canotilho. Coord. LEITE, George Salomão e SARLET, Ingo Wolfgang. São Paulo/Coimbra (PT): Revista dos Tribunais/Coimbra, 2009.

Limitações dos direitos fundamentais, in Mendes, Gilmar Ferreira e BRANCO, Paulo Gustavo Gonet, Curso de Direito Constitucional, $6^{\mathrm{a}}$ edição, São Paulo: Saraiva, 2011

MESQUITA, Maria José Rangel de. Direito da união européia, $3^{\mathrm{a}}$ edição. Lisboa: AAFDL, 2009.

MGBEOJI, Ikechi. "The civilised self and the barbaric other: imperial delusions of order and the challenges of human security" in International Law and the Third World. Nova Iorque: Routledge-Cavendish Taylor \& Francis Group, 2010.

MINISTÉRIO DA JUSTIÇA. Manual de cooperação jurídica internacional e recuperação de ativos - Matéria Penal, $1^{\text {a }}$ edição. Brasília, 2008.

Ministério Público e Investigação Criminal. São Paulo: Revista dos Tribunais. 2004;

MIRANDA, Francisco C. Pontes de Miranda. Tratado de Direito Internacional Privado, Rio de Janeiro: José Olímpio.

MIRANDA, Jorge. Manual de direito constitucional - Tomo IV, $3^{\text {a }}$ edição. São Paulo: Coimbra, 2000.

Coimbra, 2005.

Manual de direito constitucional - Tomo VI, $2^{\text {a }}$ edição. São Paulo: 
MARQUES DA SILVA, Marco Antonio (coord). Tratado Luso-brasileiro da Dignidade Humana. 2a . Ed., Quartier Latin do Brasil, 2009.

MITTERMAIER, C.J.A. Tratado de prova em matéria criminal. Campinas: Bookseller, 1997.

MORAES, Alexandre, Constituição do Brasil interpretada, 6ª ed., São Paulo: Atlas, 2006.

MORAES, Maurício Zanoide de. Presunção de Inocência no Processo Penal Brasileiro: análise de sua estrutura normativa para elaboração legislativa e para a decisão judicial. Rio de Janeiro: Lumen Juris, 2010.

MORAES, Vinícius Borges de. Concepções iusfilosóficas do direito penal do inimigo: uma análise da teoria de Gunther Jakobs in Revista Brasileira de Ciências Criminais 74, Instituto Brasileiro de Ciências Criminais. São Paulo, 2008.

MOREIRA, Vital, aula ministrada no Curso de Direitos Fundamentais, promovido pelo IBCCRIM e pela Universidade de Coimbra, no ano de 2012.

MORO, Sérgio Fernando. Cooperação jurídica internacional em casos criminais: considerações gerais, in BALTAZAR JÚNIOR, José Paulo e LIMA, Luciano Flores de (org.). Cooperação Jurídica Internacional em Matéria Penal. Porto Alegre: Verbo Jurídico, 2010.

MOSSIN, Heráclito Antonio. Nulidades no Direito Processual Penal, $3^{\text {a }}$ edição. São Paulo: Manole, 2005.

MOUTINHO, José Lobo. Arguido e Imputado no Processo Penal Português. Lisboa: Universidade Católica, 2000.

MURCHISON, Matthew. "Extradition's paradox: duty, discretion and rights in the world of non-inquiry" in 40 Standford Journal of International Law , 2007, p. 295 e seguintes.

NALINI, José Renato. Acesso à dignidade, in YARSHELL, Flávio Luiz e MORAIS, Mauricio Zanoide de. Estudos em Homenagem à Professora Ada Pellegrini Grinover, São Paulo: DPJ, 2006.

NA-NA'IN, Abdullahi Ahmed, "Why should Muslims abandon Jihad?Human rights and the future of international law", in International Law and The Third World.Reshaping Justice.Edity by Ridhard Falk, BalakrishnanRajagopal e Jacqueline Stevens, New York: Routledge-Cavendish, 2008.

NEFF, Stephen C. A Short history of International Law, in. EVANS, Malcom D. (edit.), International Law, Oxfor: Oxford University Press, 2003.

NETO, Luísa. O Direito Fundamental à disposição sobre o próprio corpo (a relevância da vontade na configuração do seu regime). Portugual: Coimbra, 2004.

NeVes Batista, Francisco das, $O$ mito da verdade real na dogmática do processo penal, Rio de Janeiro, São Paulo: Renovar, 2001.

NEYE JR., Joseph S. Cooperação e Conflito nas Relações Internacionais, Tradução de Henrique Amat Rêgo Monteiro. São Paulo: Editora Gente, 2009.

NOGUEIRA, Alberto. Viagem ao direito do terceiro milênio, Rio de Janeiro: Renovar, 2001.

NUNES, A. J. Avelãs. A Constituição Européia. A Constitucionalização do Neoliberalismo, $1^{\text {a }}$ edição brasileira. São Paulo: Revista dos Tribunais, 2007. 
NUNES, Luiz Antonio Rizzatto. O Princípio Constitucional da Dignidade da Pessoa Humana - Doutrina e Jurisprudência. São Paulo: Saraiva, 2002.

ODODO, Giuseppe e Pons, Gionvani, $O$ caso telecom. O mais grave escândalo políticofinanceiro da Itália contemporânea, FIGUEIREDO, Yadyr Augusto (trad.), Rio de Janeiro: Objetiva, 2004.

O'DWYER, Edson. Garantias constitucionais do acusado in Fascículos de Ciências Penais, ano 5, v. 5 , n. 1, Porto Alegre: Sergio Antonio Fabris Editor, 1992.

OLIVEIRA, Ana Sofia Schmidt de. A Vítima e o Direito Penal. São Paulo: Revista dos Tribunais, 1999.

OLIVEIRA, Eugênio Pacelli de. Curso de Processo Penal, 11 a edição, atualizada de acordo com a Reforma Processual Penal de 2008 e pela Lei 11.900/2009. Rio de Janeiro: Lumen Juris, 2009.

OLIVEIRA LIMA, Miria Rosynete, Devido processo legal, Porto Alegre: Sérgio Antonio Fabris, 1999.

OLIVEIRA MILLER, Marcello Paranhos de. O auxílio direto em matéria penal: A moldura jurídica de uma nova vertente de cooperação internacional. Tese de Mestrado. Rio de Janeiro: Universidade do Estado do Rio de Janeiro, 2008.

PASSOS, Calmon de, Direito, poder, justiça e processo. Julgando os que nos julgam. Rio de Janeiro: Forense, 1999.

PELLET, A.; DINH. N.Q.; DAILLIER P. Direito internacional público, Tradução Vitor Marques Coelho. Liboa: Calouste Gulbenkian, 1999.

PENTEADO, Jaques de Camargo. Duplo grau de jurisdição no processo penal - garantismo e efetividade. São Paulo: Revista dos Tribunais, 2006.

PEREIRA, Eliomar da Silva. Polícia de direitos humanos: critérios racionais de ação. in Revista Brasileira de Ciências Criminais 78, Instituto Brasileiro de Ciências Criminais. São Paulo, 2009.

PEREIRA, Raimundo Rodrigues. O escanda-lo Daniel Dantas. Duas investigações, Belo Horizonte: Manifesto, 2010.

PARISI, Nicoletta. La cooperazione giuridica Internazionale nella lotta alla corruzione”, Padova: CEDAM, 1996

PASSOS, J. J. Calmon de. Direito, poder, justiça e processo: julgando os que nos julgam. Rio de Janeiro: Forense, 1999.

PÉDRON, Pierre. La Prison et les Droits de L’homme. Paris: L.G.D.J, 1995.

PEIXINHO, Manoel Messias. As Teorias e os Métodos de Interpretação Aplicados aos Direitos Fundamentais. Doutrina e jurisprudência do STF e do STJ. Rio de Janeiro: Lumen Juris, 2010.

PEREIRA, Rui. Entre o Garantismo e o Securitarismo in Que Futuro para o Direito Processual Penal? Simpósio em homenagem a Jorge de Figueiredo Dias, por ocasião dos 20 anos do Código de Processo Penal Português. Coimbra: Coimbra Editora, 2009, pp 247-268.

PIERANGELI, José Henrique. Direito Criminal 3. Belo Horizonte: Del Rey, 2001. 
O Consentimento do Ofendido (na Teoria do Delito). São Paulo, 1995.

1983.

Processo penal: Evolução, história e fontes legislativas. Bauru: Javoli,

PINHEIRO, Rui; MAURÍCIO, Artur. A Constituição e o processo penal. São Paulo: Coimbra, 2007.

PINTO, Ana Luísa. A celeridade no processo penal: o direito à decisão em prazo razoável. Lisboa: Coimbra, 2008.

PINTO, Ronaldo Batista. Prova Penal segundo a jurisprudência. São Paulo: Saraiva, 2000.

PIOVESAN, Flávia. "Hierarquia dos tratados internacionais de proteção aos direitos humanos: jurisprudência do STF” in AMARAL JUNIOR, Alberto do; JUBILUT, Liliana Lyra. O STF e o direito internacional dos direitos humanos. São Paulo: Quartier Latin, 2009

Direitos Humanos e Justiça Internacional. Um estudo comparativo dos sistemas regionais europeu, internacional e africano, $1^{a}$ edição. São Paulo: Saraiva, 2007.

Igualdade, Diferença e Direitos Humanos: Perspectiva Global e Regional, in SARMENTO, IKAWA, DANIELA, Daniel e PIOVESAN, Flávia (coord.). Igualdade, Diferença e Direitos Humanos, $2^{\text {a }}$ tiragem, Rio de Janeiro: Lumen Juris, 2010

Polin, Raimond. Le concept de sourerainetéet se consequencesinternationals. in. Drago Roland (Org.). Souveraneté de l'Etat et interventioninternationes. Paris: Dalloz, 1996.

PONTE, Ana Lúcia Menezes Vieira da. "O Processo Penal como Garantia: Direito ao Conhecimento Prévio da Acusação" in Justiça Penal Críticas e Sugestões -6. 10 Anos da Constituição e a Justiça Penal, Meio Ambiente, Drogas, Globalização, O Caso Pataxó. São Paulo: Revista dos Tribunais, 1999, pp 361-396.

PITOMBO, Cleunice A. Valentim Bastos. Força probante dos indícios e sentença condenatória, in Boletim do IBCCRIM, ano 21 n. ${ }^{\circ} 242$, janeiro/2013.

Piтомво, Sérgio Marcos de Moraes, O juiz penal e a Pesquisa da Verdade Material, in Processo Penal e Constituição Federal, Hermínio Marques Porto e Marco Antonio Marques da Silva (coord.), São Paulo: Academia, 1993.

A polícia judiciária e as regras orientadoras do processo penal. In. Moraes, Bismael B. (Coord.). A polícia à luz do direito. São Paulo: RT, 1991

PRADO, Luiz Regis, Bem jurídico-penal e constituição. São Paulo: RT, 1997.

PRONER, Carol. Os Direitos Humanos e seus paradoxos: análise do sistema americano de proteção. Porto Alegre: Sergio Antonio Fabris Editor, 2002.

QUEIROZ, Cristina. O princípio da não reversibilidade dos direitos fundamentais. Princípios dogmáticos e práticas jurisprudenciais. Coimbra: Coimbra Editoras, 2006.

QUEIJO, Maria Elizabeth. O direito de não produzir prova contra si mesmo. O princípio Nemo tenetur se detegere e suas decorrências no processo penal. São Paulo: Saraiva, 2003.

QUITERO, Cristiane Bernades Antunes e PonTES, José Antonio Siqueira Evolução das garantias constitucionais relativas ao processo penal na América Latina. in CHOUK, Fauzi Hassan (org.). Estudos de processo penal: o mundo à revelia, SP: Aga Juris, 2000. 
RABONEZE, Ricardo. Provas Obtidas por Meios Ilícitos, $3^{\mathrm{a}}$ edição. Revista e Ampliada . Porto Alegre: Síntese, 2000.

RAILDA, Saraiva, A constituição de 1988 e o ordenamento jurídico-penal brasileiro, Rio de Janeiro: Forense, 1992.

RAJAGOPAL, Balakrishnan. "Counter-hegemonic International Law: rethinking human rights and development as a Third World strategy" in International Law and the Third World. Nova Iorque: Routledge-Cavendish Taylor \& Francis Group, 2010.

RAMOS, Elival daSilva. Os tratados sobre direitos humanos no Direito Constitucional Brasileiro, in AMARAL JR., Alberto do, e JUBILUT, Lilian Lyra (orgs), O STF e o Direito Internacional dos Direitos Humanos. São Paulo: QuartierLatin, 2009.

RAMOS, João Gualberto Garcez. A tutela de urgência no processo penal brasileiro doutrina e jurisprudência. Belo Horizonte: Del Rey, 1998.

RAMOS, Galdino Luiz Ramos. Princípios Constitucionais do Processo. Visão Crítica. São Paulo: Juarez de Oliveira, 2000.

RANGEL. Vicente Marotta. Direitos e Relações Internacionais. $7^{a}$ Ed., ver. atual. E ampl. São Paulo: Revista dos Tribunais, 2002;

RAWLS, John. Uma teoria da justiça. São Paulo: Martins Fontes, 1997.

REZEK, José Francisco. Direito internacional Público: curso elementar. $13^{\text {a }}$ Ed. rev., aumen. e atual. São Paulo: Saraiva, 2011.

RIPOLLÉS, Antonio Quintano. Tratado de Derecho Penal Internacional e Internacional Penal. Madrid: Instituto Francisco Vitoria, 1955.

RIQUITO, Ana Luíza, et alii, Carta de Direitos Fundamentais da União Europeia, Portugal, Coimbra: 2001

ROCHA, João Carlos de Carvalho; HENRIQUES FILHO, Tarcísio Humberto Parreiras; CAZETTA, Ubiratan. Crimes contra o sistema financeiro nacional. Belo Horizonte: Del Rey, 2006.

ROCHA, Luiz Alberto G. S., Estado, Democracia e Globalização. Rio de Janeiro: Forense, 2008.

RODRIGUES, Anabela Miranda, MOTA, José Luis Lopes da, Para uma Política Criminal Européia. Portugal: Coimbra Editora, 2002.

ROTHENBURG, Walter Claudius. Princípios Constitucionais. Porto Alegre: Sergio Antonio Fabris Editor, 1999.

ROXIN, Claus. Derecho Procesal Penal. 25a edição. Buenos Aires: Del Puerto, 2000.

. Problemas fundamentais de direito penal. $3^{\text {a }}$ edição. Lisboa: Veja, 2004.

. "Conferência Inaugural sobre o Desenvolvimento do Direito Processual Penal Alemão" in Que Futuro para o Direito Processual Penal? Simpósio em homenagem a Jorge de Figueiredo Dias, por ocasião dos 20 anos do Código de Processo Penal Português. Portugal: Coimbra Editora, 2009, pp 385-398.

SAAD, Marta. O Direito de Defesa no Inquérito Policial. São Paulo: Revista dos Tribunais, 2004. 
SAINT-LAURENT, Danièle. Pricipes de droit constitucionel et pénal. Quebec, Modulo ed., 1986, p. 124;

SÁNCHEZ, Jesús-María Silva. A expansão do direito penal. São Paulo: Revista dos Tribunais, 2002.

SANTOS, Manuel Simas. "Revisão do Processo Penal: Os Recursos.” in: Que Futuro para o Direito Processual Penal? Simpósio em homenagem a Jorge de Figueiredo Dias, por ocasião dos 20 anos do Código de Processo Penal Português. Portugal: Coimbra Editora, 2009, pp 165-206.

SARLET, Ingo Wolfgang. A eficácia dos diretos fundamentais. Porto Alegre: Livraria do advogado, 2010

Dimensões da dignidade: Ensaios de filosofia do direito e direito constitucional. Porto Alegre: Livraria do Advogado, 2008.

SARMENTO, Daniel , IKAWA, Daniela e PIOVESAN, Flávia. Igualdade, Diferença e Direitos Humanos, $2^{\text {a }}$ tiragem. Rio de Janeiro: Lumen Juris, 2010.

SATZGER, Helmut, e ZIMMERMANN, Frank, Dos modelos tradicionais de Cooperação Judicial ao Princípio do Reconhecimento Mútuo: Novos desdobramentos do verdadeiro paradigma da cooperação europeia em matéria penal. in Baltazar Júnior e Lima, Luciano Flores (org.). Cooperação jurídica internacional em matéria penal, Porto Alegre: Verbo Divino, 2010

SCHILLING, Flávia. Corrupção: ilegalidade ou intolerável?. São Paulo: IBCCRIM, 1999.

SEITENFUS, Ricardo. Manual das Organizações Internacionais, $3^{\mathrm{a}}$ edição revista e ampliada. Porto Alegre: Livraria do Advogado Editora, 2003.

SEIXAS, Raimundo Jorge Santos; NAGADO, Bartira Meira Ramos, “A atuação do Brasil no banco dos reus no sistema interamericano de proteção aos direitos humanos" in Dos Direitos Humanos aos Direitos Fundamentais. Porto Alegre: Livraria do advogado, 2007.

SHECAIRA, Sérgio Salomão. Estudos criminais em homenagem a Evandro Lins e Silva. Belém: Cejup, 1996.

SILVA, Ricardo Perlingeiro Mendes da. Cooperação Jurídica Internacional e auxílio direto, in TIBURCIO, Carmem, BARROSO, Luís Roberto (orgs.). O direito internacional contemporâneo: estudo em homenagem ao professor JacbDolinger. Rio de Janeiro: Renovar, 2006.

SILVA, Edson Ferreira da. Direito à intimidade. São Paulo: Oliveira Mendes, 1998.

SILVA, José Afonso. Aplicabilidade das normas constitucionais, $3^{\text {a }}$ edição. São Paulo: Malheiros, 1997.

SILVA, Karine de Souza. Direito da comunidade européia. Ijuí: Unijuí, 2005.

SILVA, Marco Antonio Marques da. Tratado Temático de Processo Penal. São Paulo: Juarez de Oliveira, 2002.

SILVA, Ricardo Perlingeiro Mendes da. "Cooperação jurídica internacional e auxilio direto". Revista CEF, Brasília-DF, v.32, p. 75-79, 2006. 
SILVA, Virgílio Afonso da. Teoria dos direitos fundamentais, $2^{\mathrm{a}}$ edição. São Paulo: Malheiros, 2006.

SILVA, José Afonso da, Curso de Direito Constitucional Positivo, São Paulo: Malheiros. 2013.

Silva Franco, Alberto da. Globalização e Criminalidade dos Poderosos, in Podval, Roberto (org.), Temas de Direito Penal Econômico, São Paulo: RT, 2000.

SILVA JARDIM, Afrânio da. Bases constitucionais para um processo penal democrático. in Direito processual penal: Estudos e Pareceres. Rio de Janeiro: forense, 1995.

SILVA LEAL, Rui da. Eu sou arguido... Amanhã. Os direitos de garantia in .Que Futuro para o Direito Processual Penal? Simpósio em homenagem a Jorge de Figueiredo Dias, por ocasião dos 20 anos do Código de Processo Penal Português.Coimbra: Coimbra Editora, 2009, pp 116-126.

SILVA NETO, Manoel Jorge e. O Princípío da Máxima Efetividade e a Interpretação Constitucional. São Paulo: LTr, 1999.

SILVA RAMOS, Elival da. "Os tratados sobre direitos humanos no direito constitucional brasileiro pós-emenda constitucional 45/05" in AMARAL JUNIOR, Alberto do; JUBILUT, Liliana Lyra. O STF e o direito internacional dos direitos humanos. São Paulo: QUartier Latin, 2009

SIQUEIRA, Galdino. Direito Penal Brasileiro.

SLAUGHTER, Anne-Marie. "Sovereingnty and Power in a Networked World Order" in 40 Stanford Journal of International Law (2004) p. 2004.

SUANNES, Adauto, Os fundamentos éticos do devido processo legal. São Paulo: RT, 1999.

SZNICK, Valdir. Tortura. São Paulo: Leud, 2008.

SOARES, Guido Fernando Silva. Curso de Direito Internacional Público. V. 1. São Paulo: Atlas, 2002.

Direito Internacional, humanismo e globalidade. São Paulo: Atlas, 2008.

"O Meio Ambiente e a Justiça no Mundo Globalizado" in Justiça Penal Críticas e Sugestões - 6.10 Anos da Constituição e a Justiça Penal, Meio Ambiente, Drogas, Globalização, O Caso Pataxó. São Paulo: Revista dos Tribunais, 1999, pp 65118.

SOUZA, Carolina Yumi de. Cooperação jurídica internacional em matéria penal: considerações práticas in Revista Brasileira de Ciências Criminais 71, ano16, São Paulo: RT, março-abril de 2008.

A defesa na cooperação jurídica internacional - reflexões preliminares, in Boletim do IBCCRIM 214 - setembro/2010.

SOUZA, Luciano Anderson de. Expansão do Direito Penal e Globalização. São Paulo: Quartier Latin do Brasil, 2007.

SOUZA NUCCI, Guilherme de. O valor da Confissão como meio de prova no Processo Penal, $2^{a}$ edição revista e atualizada, com comentários à Lei de Tortura. São Paulo: Revista dos Tribunais, 1997. 
SouZA SANTOS, Boaventura, Para uma Concepção Intercultural dos Direitos Humanos, in Igualdade, Diferença e Direitos Humanos, Daniel Sarmento, Daniela Ikawa e Flávia Piovesan (org.), $2^{\text {a }}$ tiragem, Rio de Janeiro: Lumen Juris, 2010.

SOUZA NUCCI, Guilherme de, Código de processo penal comentado. Estudo integrado com Direito Penal e Execução Penal. Apresentações esquemáticas da matéria. $11^{\mathrm{a}} \mathrm{ed}$., São Paulo RT, 2012, p. 156.

SOUZA Silva, Karine de, Direito da Comunidade Europeia, Fontes, Princípios e Procedimentos. Ijuí: Unijuí, 2005.

SOUZA, Solange Mendes de, Cooperação jurídica Penal no MERCOSUL: Novas Possibilidades, Rio de Janeiro: Renovar, 2006.

SUANNES, Adauto. Os Fundamentos Éticos do Devido Processo Penal. São Paulo: Revista dos Tribunais, 1999.

TACHINARI, Maria Helena. Roberto Müller Filho. Intuição, Política e Jornalismo. São Paulo: Imprensa Oficial, 2010.

TANZIA, Giuseppe, Parità dele armi trale parti e poteri del giudicenel processo civile, Problemi del processo civile di cognizione. Pádua: Cedam, 1989.

TARUFFO, Michele. "Garanzie processuali e dimensione transnazionale della giustizia civile" in Estudos em Homenagem à Professora Ada Pellegrini Grinover. São Paulo: DPJ, 2006. Cedam, 1975.

Il diritto ala prova nel processo civile, in RivistadiDirittoProcessuale. Páuda:

TAVARES, André Ramos, Curso de Direito Constitucional, $11^{\mathrm{a}}$ ed. revista e atualizada, São Paulo: Saraiva, 2013.

TIBURCIO, Carmen, Temas de Direito Internacional. Rio de Janeiro: Renovar, 2006.

TONINI, Paolo. A prova no processo penal italiano. Tradução de Alexandra Martins e Daniela Mróz. São Paulo: Revista dos Tribunais, 2001.

TORRES, Ricardo Lobo, KATAOKA, Eduardo Takemi, GALDINO, Flavio (org.), Dicionário de Princípios Jurídicos, Rio de Janeiro: Elsevier, 2011.

TOTHWAX, Harold J. Guilty. The collapse of criminal justice, New York: Random House, 1996.

TRINDADE, Antonio Augusto Cançado. A humanização do direito Internacional. Belo Horizonte: Del Rey, 2006.

Direito das Organizações Internacionais, $4^{\mathrm{a}}$ edição. Belo Horizonte: Del Rey, 2009.

TORRES, Ricardo Lobo. Legitimação dos direitos humanos. Rio de Janeiro: Renovar, 2002.

Trechsel, Stefan. Human Rights in Criminal Proceedings. Oxford: Osxford University Presss, 2005.

TUCCI, Rogério Lauria. Direitos e Garantias Individuais no Processo Penal Brasileiro, $4^{\mathrm{a}}$ edição revista, atualizada e ampliada. São Paulo: Revista dos Tribunais, 2011.

Teoria do Direito Processual Penal, São Paulo: Revista dos Tribunais, 2002. 
Princípios e regras orientadoras do processo penal brasileiro. Rio de Janeiro: Forense, 1986.

TUCCI, Rogério Lauria e TuCCI, José Rogério Cruz, Constituição de 1988 e processo: Regramentos e Garantias Constitucionais do Processo. São Paulo: Saraiva, 1989.

UBERTIS, Gilio. Il contraddittorio nella formazione della prove penale, in Estudos em homenagem à Professora Ada Pellegrini Grinover, YARSHAL, Flávio Luiz e ZANOIDE, Mauricio de, São Paulo: DPJ editora, 2005

VALladÃo, Haroldo. Direito Internacional Privado. Rio de Janeiro: Freitas Bastos, Volume III, 1978.

VARGAS, José Cirilo de. Direitos e garantias individuais no processo penal. Rio de Janeiro: forense, 2002.

VERVAELE, John A. E. O Mercosul e a integração regional na América Latina, tradução de José Paulo Baltazar Junior, in BALTAZAR JÚNIOR, José Paulo e LIMA, Luciano Flores de (org). Cooperação Jurídica Internacional em Matéria Penal. Porto Alegre: Verbo Jurídico, 2010.

VIERIA, Litz, Cidadania e Globalização. Rio de Janeiro: Record, 1997

VIEIRA, Renato Stanziola, Traços adversariais no Projeto de Código de Processo Penal. Uma proposta para o estudo da paridade de armas, in kehdievieira.com.br .

YARSHELL, Flávio Luiz. Antecipação da prova sem o requisito da urgência e direito autônomo à prova. São Paulo: Malheiros, 2009.

WALD, Arnoldo, Confiança (Princípio da), in TORRES, Ricardo Lobo, KATAOKA, Eduardo Takemi, GALDINO, Flavio (cord.), Dicionário de Princípios Jurídicos, Rio de Janeiro: Elsevier, 2011.

WALDRON, Jeremy. Theories of Rights (Oxford readings in Philosophy), First published. Oxford: Oxford University Press, 1984.

WALKER, Neil. Europe's Area of freedom, security and justice. Nova Iorque: Oxford, 2004.

WAMBIER, Luiz Rodrigues e TALAMINI, Eduardo (cord.), Curso Avançado de Processo Civil. vol. 1, 9a ed., São Paulo: RT, 2009.

ZILLI, Marcos Alexandre Coelho. A prova ilícita e o tribunal penal internacional: regras de admissibilidade. Tese de doutorado. São Paulo: Universidade de São Paulo, 2009.

As garantias da liberdade individual em face das novas tendências penais. São Paulo: USP, 1936.

Sítios da internet:

http://portalmj.com.br

http://corteidh.or.cr/opiniones.cfm.

http://www.stf.jus.br

http://www.stj.jus.br

http://e-jutice.europa.eu

http://echr.coe.int/ 
http://itamaraty.gov.br

portal.mj.gov.br

http://www.corteidh.or.cr/opiniones.cfm

www.jstor.org.stable/2194372

www.ascji.pgr.mpf.gob.br/atuacao-da-ccji/redes-de-cooperacao-juridica

www.echr.coe.int/echr

http://pt.wikipedia.org/wiki/Uni\%C3\%A3o_Europeia

http://pt.wikipedia.org/wiki/Europol

http://eurojust.europa.eu/Pages/languages/pt.aspx

www.consilium.europa.eu/eudocs/pressData/en/ec/00200-r1

www.consilium.europa.eu/uedocs/cms-data/doc.

www.europa.eu/legislation_summaries/justice_freedom_security/judicial.

www.consilium.europa.eu/uedocs/cms_data/doc

www.mercosur.int/msweb/Normas/normas_web/Decisiones/PT/Dec_016_000_Centro\%20Ca pacita\%C3\%A7\%C3\%A3o\%20Policial_Ata\%201_00.PDF

pgr.mpf.gov.br/noticias-do-site/copy_of_pdfs/declaração

www.conjur.com.br

sítio da internet da Corte Interamericana de Direitos Humanos.

www.ficen.gov/news_room/ea/files/hartsfieldassessement.pdf.

www.justice.gov/eousa/foia_reading_room/usam/title9/13mcrm.htm\#9-13.525 